\title{
A Guide to Ceramics from Spanish Colonial Sites in Texas
}

Anne A. Fox

Center for Archaeological Research

Kristi M. Ulrich

Center for Archaeological Research

Follow this and additional works at: https://scholarworks.sfasu.edu/ita

Part of the American Material Culture Commons, Archaeological Anthropology Commons, Environmental Studies Commons, Other American Studies Commons, Other Arts and Humanities Commons, Other History of Art, Architecture, and Archaeology Commons, and the United States History Commons

Tell us how this article helped you.

This Article is brought to you for free and open access by the Center for Regional Heritage Research at SFA ScholarWorks. It has been accepted for inclusion in Index of Texas Archaeology: Open Access Gray Literature from the Lone Star State by an authorized editor of SFA ScholarWorks. For more information, please contact cdsscholarworks@sfasu.edu. 
A Guide to Ceramics from Spanish Colonial Sites in Texas

Creative Commons License

(c) $)(1)$ (9)

This work is licensed under a Creative Commons Attribution-NonCommercial 4.0 International License 


\section{A Guide to Ceramics from Spanish Colonial Sites in Texas}

by

Anne A. Fox and Kristi M. Ulrich

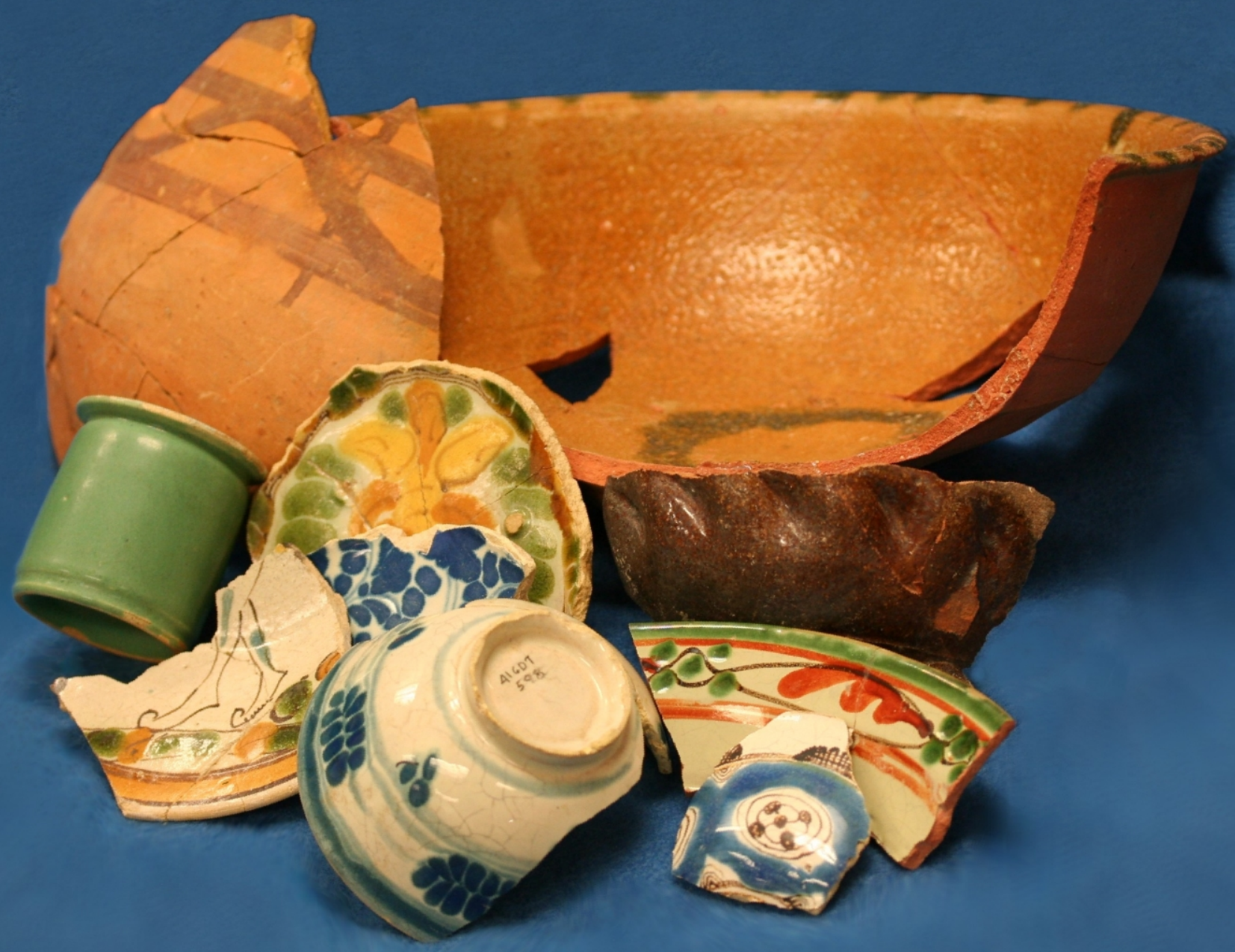

Center for Archaeological Research The University of Texas at San Antonio Special Report No. 33 


\title{
A GuIDE TO CERAMICS FROM SPANISH COLONIAL SITES IN TEXAS
}

\author{
Anne A. Fox \\ and \\ Kristi M. Ulrich \\ With contributions by Barbara A. Meissner \\ Center for Archaeological Research \\ The University of Texas at San Antonio
}

Special Report \# 33

(C) CAR-UTSA 2008 


\section{TABLE OF CONTENTS}

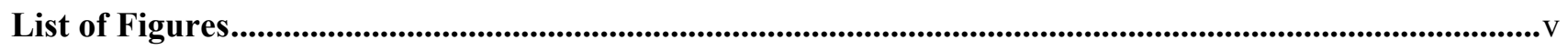

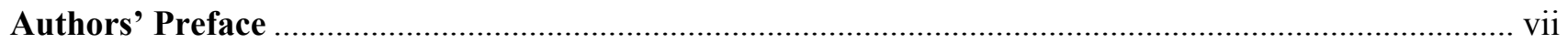

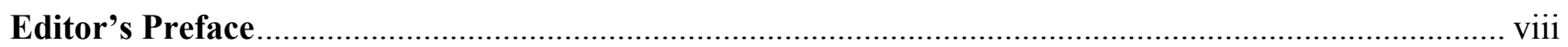

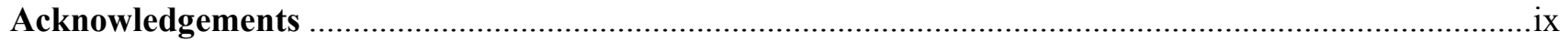

Chapter 1: Missions, Presidios, and Villas of Spanish Texas.........................................................

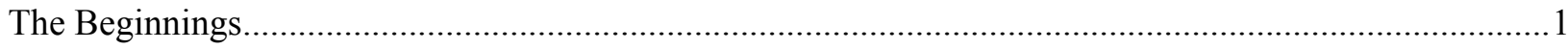

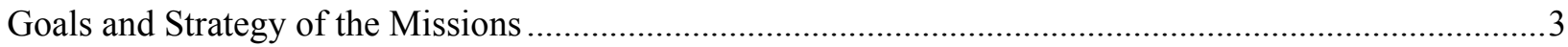

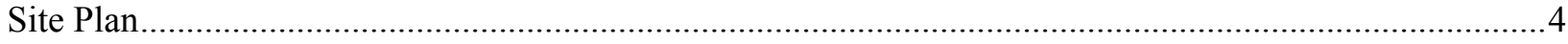

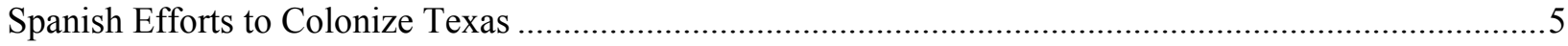

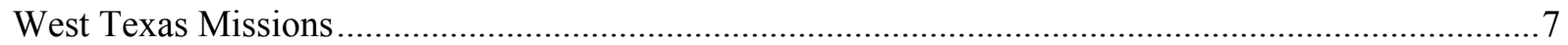

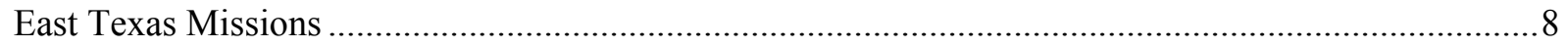

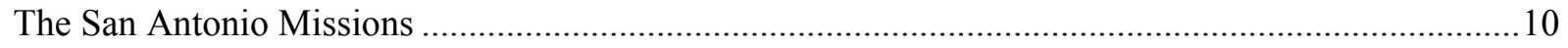

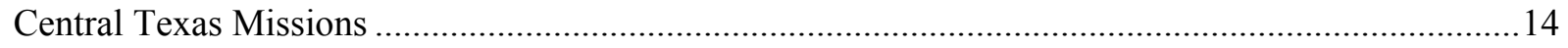

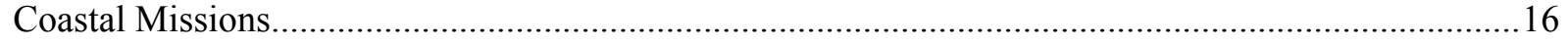

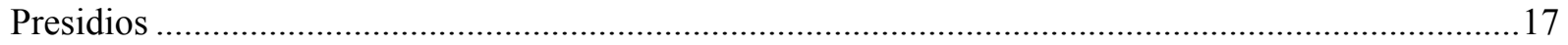

Chapter 2: Ceramic Manufacturing in Mexico and Supplying the Missions and Presidios of Texas.....21

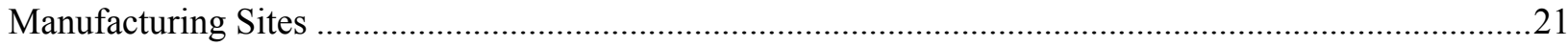

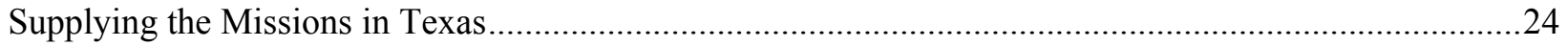

Chapter 3: Defining Variation in Manufacture, Surface Treatments, and Vessel Forms in Spanish

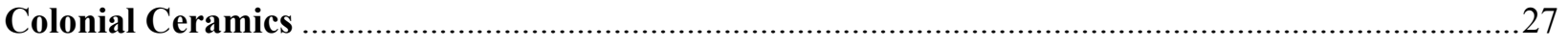

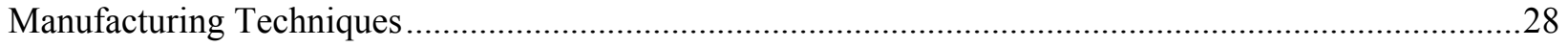

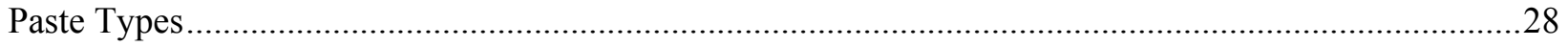

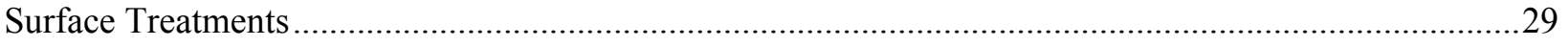

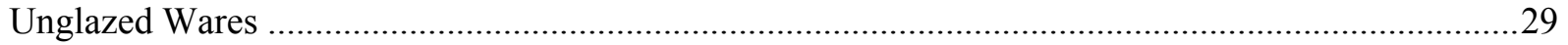

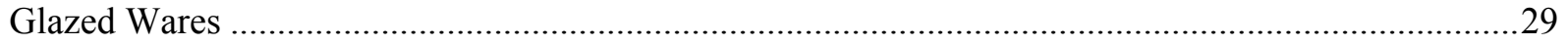

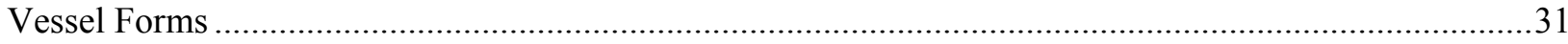

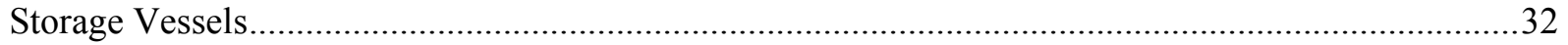

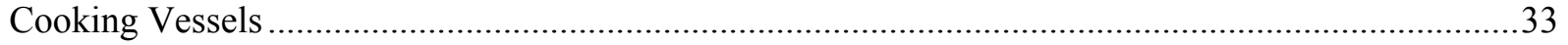

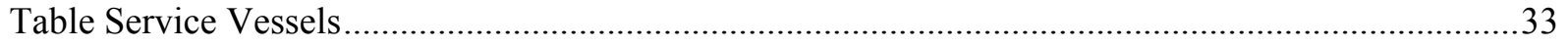

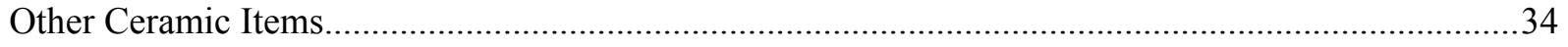

Chapter 4: Ceramics from Spanish Colonial Sites in Texas ...............................................................3

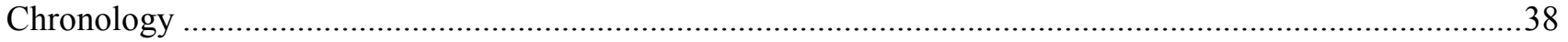

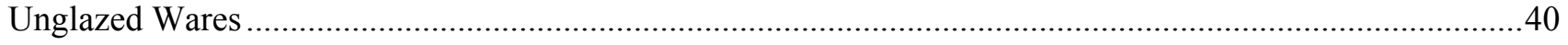


Valero Red Painted.

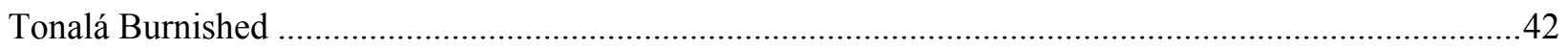

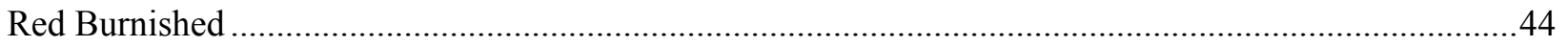

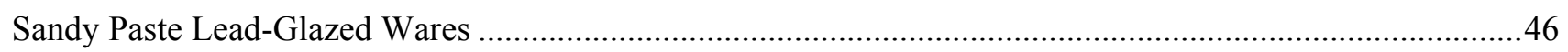

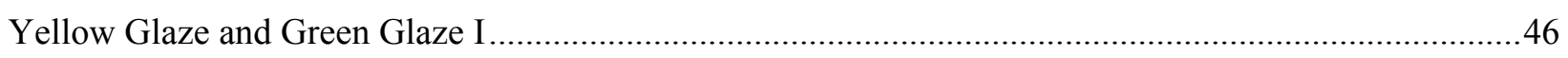

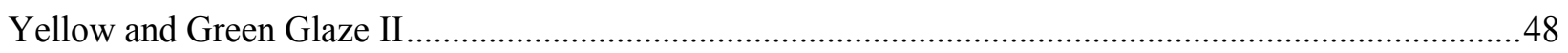

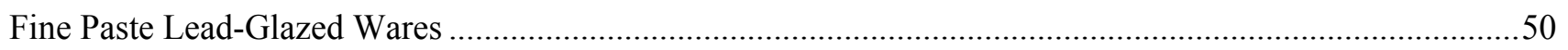

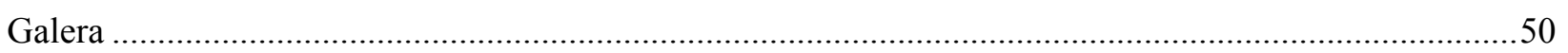

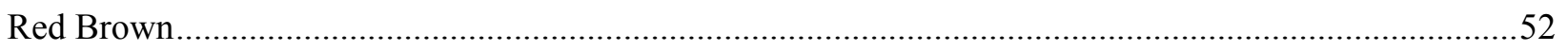

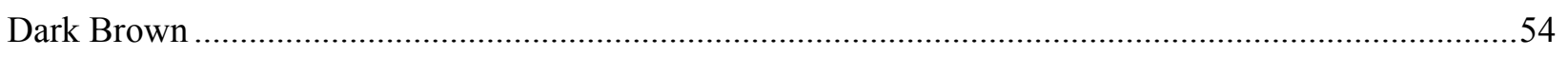

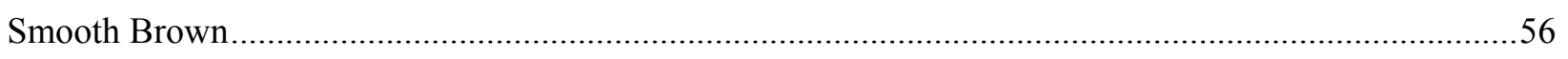

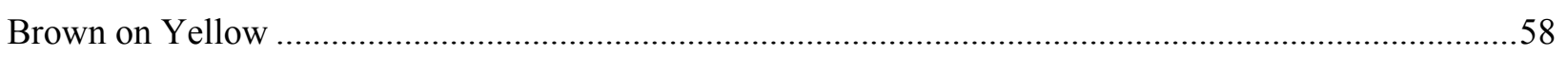

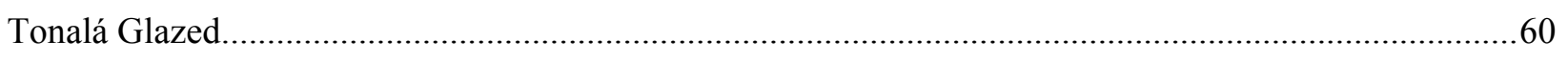

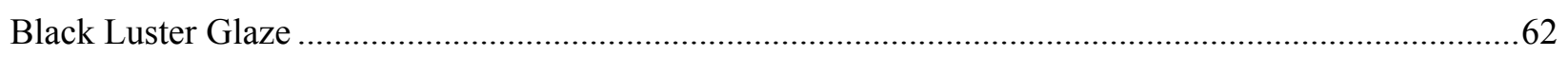

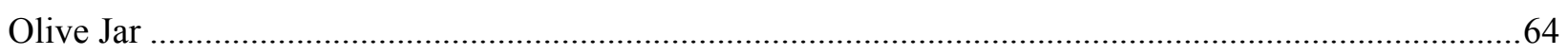

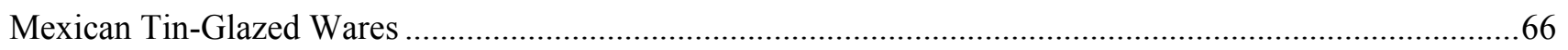

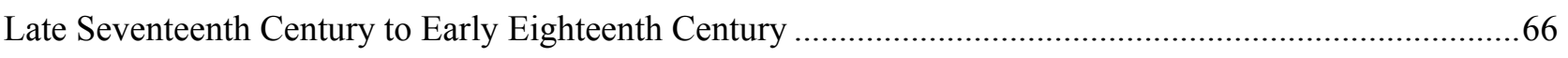

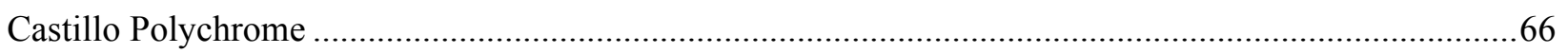

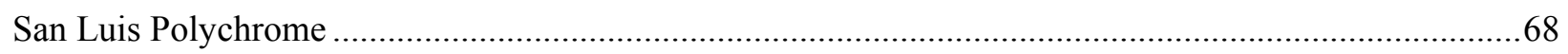

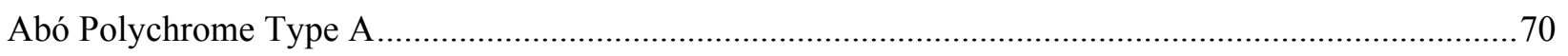

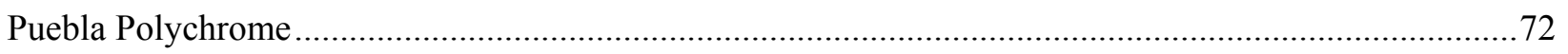

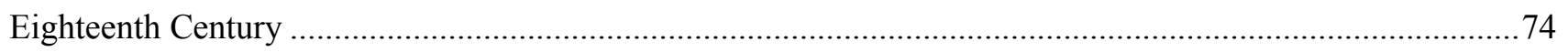

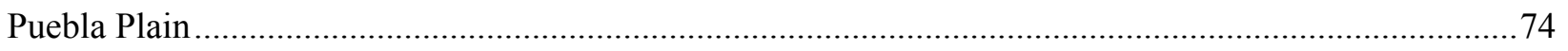

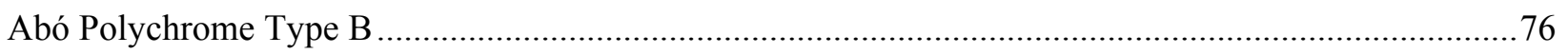

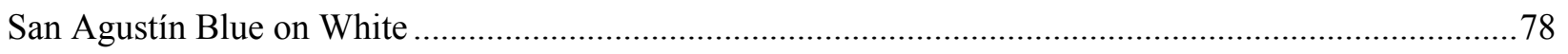

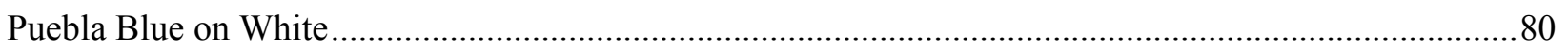

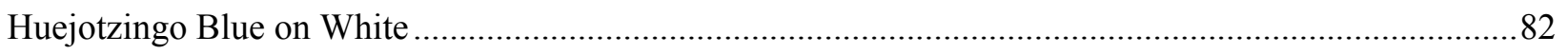

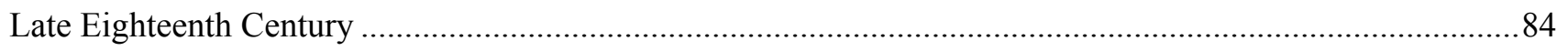

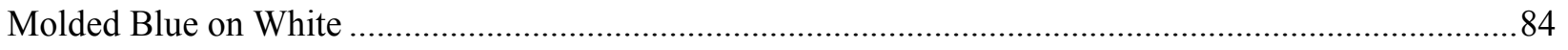

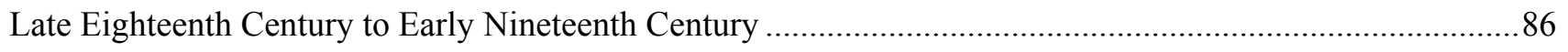

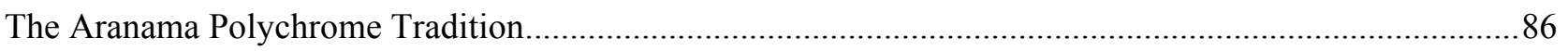

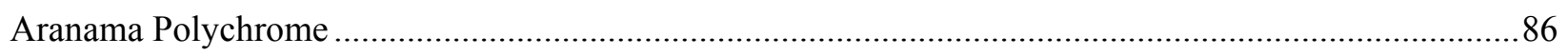

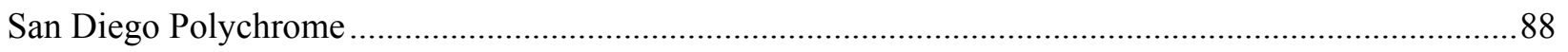

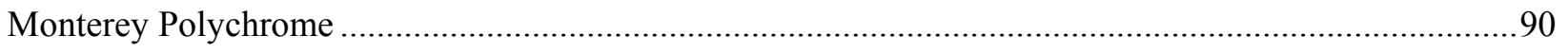

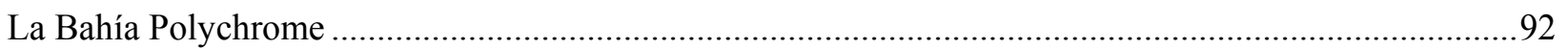


Orange Band Polychrome.

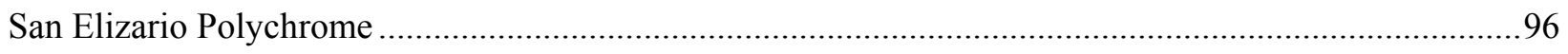

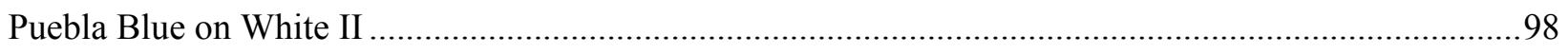

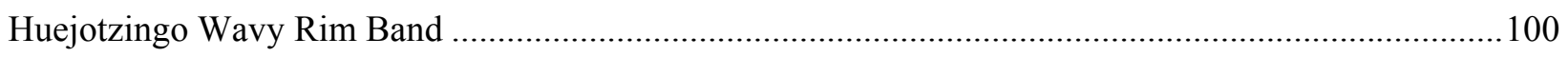

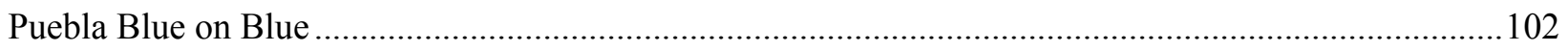

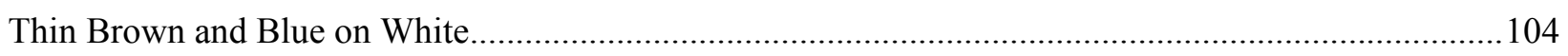

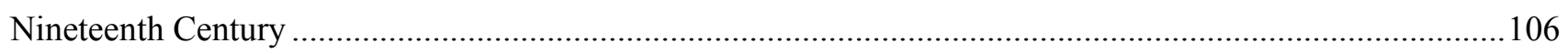

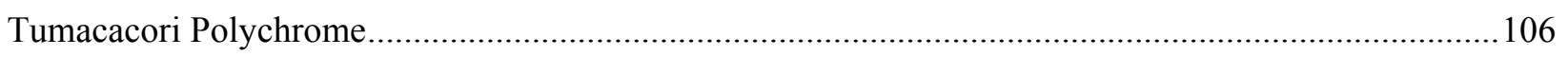

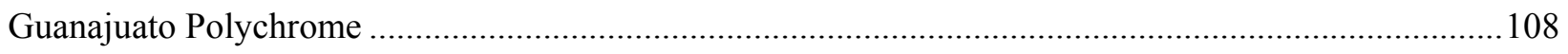

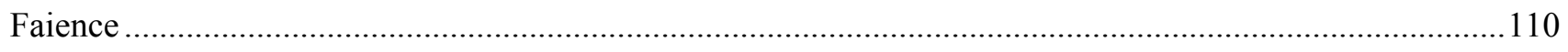

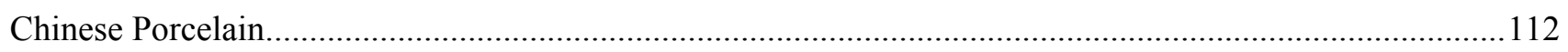

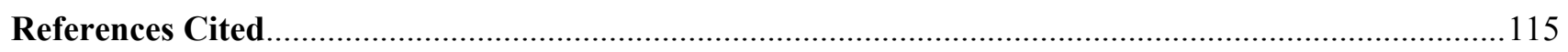

Appendix A: Glossary of Terms Used in Ceramic Analysis ..........................................................125

Appendix B: Bibliography of Archaeological Research at Spanish Colonial Sites in Texas, Barbara

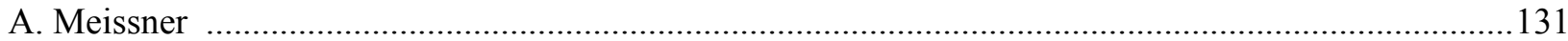




\section{LIST OF FigURES}

Figure 1-1. Map showing locations of known Spanish Colonial Sites. .................................................... 6

Figure 2-1. Map showing locations of Mexican ceramics manufacturing in the Colonial period............. 22

Figure 3-1. Examples of tin (a) and lead-glazed (b-c) specimens............................................................ 30

Figure 3-2. Examples of large storage containers: a) jarro; b) cántaro; c) tinaja; d) orza...................... 32

Figure 3-3. Examples of table service vessels: a) plato; b) sopero; c) taza d) pocillo; e) escudilla f)

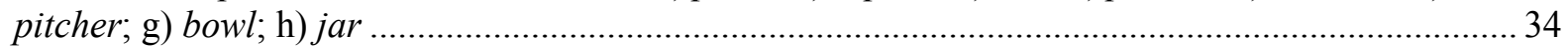

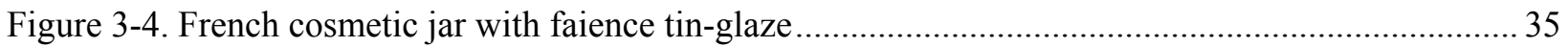

Figure 4-1. Chronology of ceramics from Spanish colonial sites in Texas ............................................... 39

Figure 4-2. Valero Red Painted. 41WN30: a, c,d; 41BX6: b................................................................. 41

Figure 4-3. Tonalá Burnished. 41GD7:a, d, e; 41BX5: b, c; 41BX6: f................................................... 43

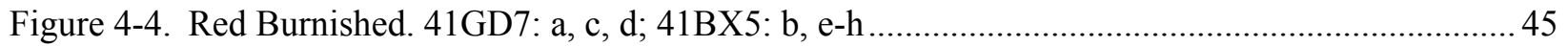

Figure 4-5. Yellow Glaze and Green Glaze I. 41BX5: a, d, e; 41BX3: b; 41BX4: c ............................ 47

Figure 4-6. Yellow and Green Glaze II. 41BX5: a-g; 41BX4: h ....................................................... 49

Figure 4-7. Galera. 41GD7: a, e, g-i; 41BX4: f; 41BX5: c, d; 42BX6:b. .......................................... 51

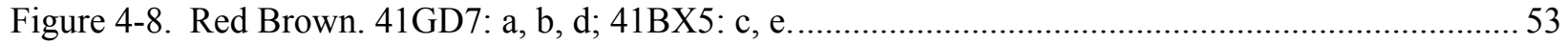

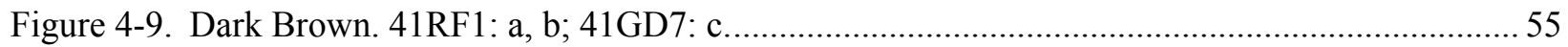

Figure 4-10. Smooth Brown. 41GD7: a- c, e; 41BX5: d. ..................................................................... 57

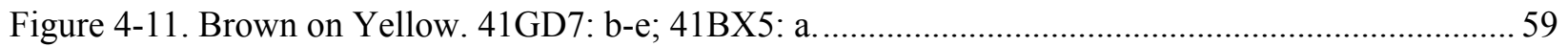

Figure4-12. Tonalá Glazed. 41GD7: a, c: 41RF1: e-g; 41BX5: d; 41BX6: b ........................................ 61

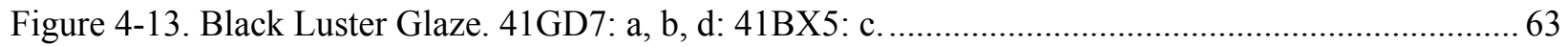

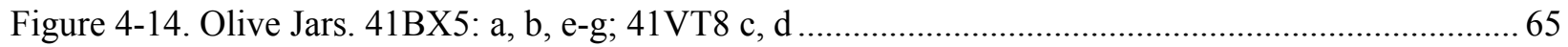

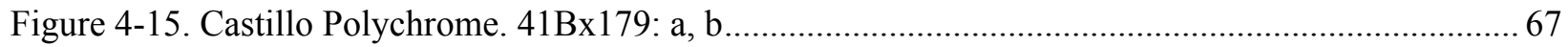

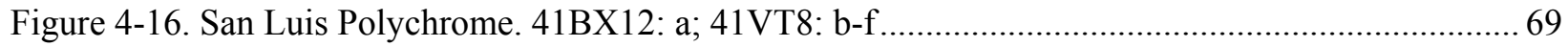

Figure 4-17. Abó Polychrome, Type A. a) Courtesy of the Florida Museum of Natural History .............. 71

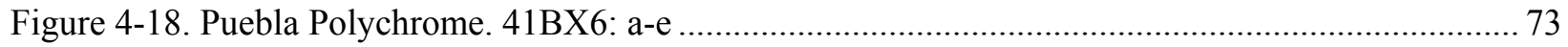

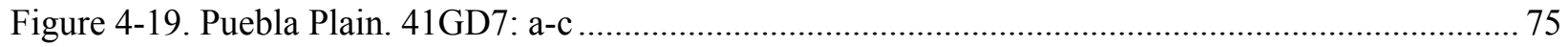

Figure 4-20. Abó Polychrome, Type B. 41GD7: a, b; c) Courtesy of the Florida Museum of Natural

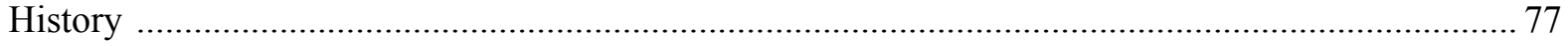

Figure 4-21. San Agustín Blue on White: 41GD7: a,-c, e-g; 41VT8: d.................................................. 79

Figure 4-22. Puebla Blue on White. 41Bx12: a; 41BX3: b; 41GD7: c.................................................. 81

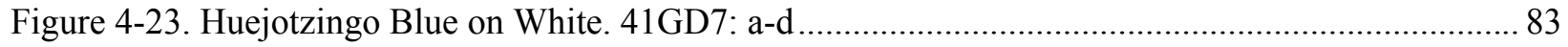

Figure 4-24. Molded Blue on White. 41BX12: a; 41GD7: b, d, e, g, i-1, o; 41BX3: c; 41BX5: f, m, n.....85

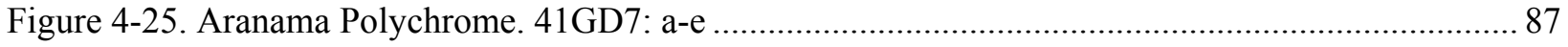

Figure 4-26. San Diego Polychrome. 41WN30: a; 41GD7: b, c, e; 41BX6: d; 41BX5: f........................ 89 
Figure 4-27. Monterey Polychrome. 41GD7: a-e; 41WN30; f; 41BX5: g-h ....................................... 91

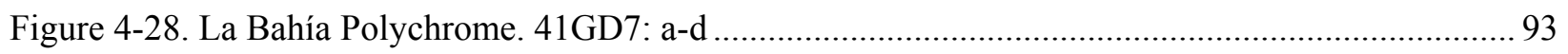

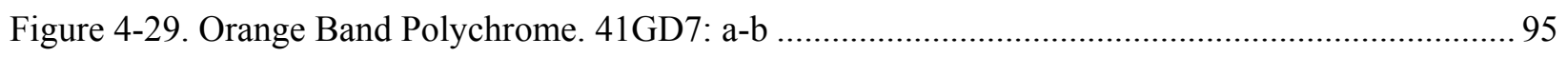

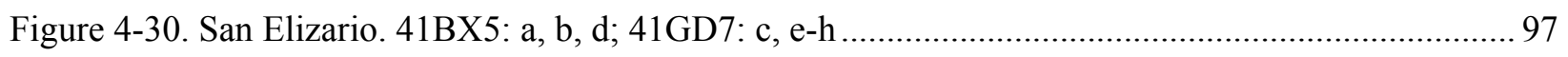

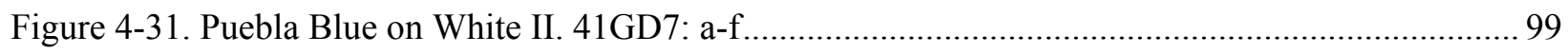

Figure 4-32. Huejotzingo Wavy Rim Band. 41GD7: a-c, e; 41BX 5: d .............................................. 101

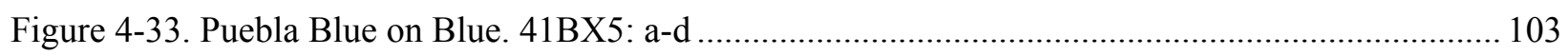

Figure 4-34. Thin Blue on Brown on White. 41Bx5: a, b; 41GD7: c-e................................................ 105

Figure 4-35. Tumacacori Polychrome. 41GD7: a, c-e; 41BX6: b ....................................................... 107

Figure 4-36. Guanajuato Polychrome. 41BX6: a; 41BX5: b, f; 41GD7: c-e, g, h................................ 109

Figure 4-37. Faience. 41GD7: a, c-g, j; 41WN30: b; 41CH51: h; 41BX5: i ....................................... 111

Figure 4-38. Chinese Porcelains. 41GD7: a, b, e, f, h-m; 41BX3: c; 41WN30: g................................. 113 


\section{Authors’ Preface}

The descriptions of ceramic types in this publication are compiled primarily as an aid to archaeologists working at missions and presidios in Texas, though it will also help those investigating town and ranch sites occupied during the eighteenth century. It was written with the help of numerous site reports done by archaeologists throughout the twentieth century who have valiantly wrestled with the problems of type identification and dating. The senior author has had the privilege of working with many of them throughout this period, and has developed an intense interest in ceramic identification. Additional help has come from researchers who have created and refined the ceramic typology over the years, from John Goggin in 1968 to Kathleen Deagan in 1987. The research of Florence and Robert Lister (1974, 1975, 1976a, 1976b, 1978) has contributed priceless information on the identification and origins of majolicas.

Researchers working on Spanish colonial sites in Texas become aware that there are ceramic types that Goggin or Deagan do not describe. This is partly because the authors did not have access to Texas collections (Goggin 1968:81-83) or were limiting their typologies to the Caribbean area (Deagan 1987). At first, we avoided the problem by designating types with no known names as "Type A, Type B, etc." The senior author has taken her courage in both hands and started to use descriptive names, especially for the coarse wares that have generally been ignored (see Fox 2002:203-219; Gilmore 1974:55-69) as well as the majolicas found on Texas sites that existed into the nineteenth century. This has also increased our appreciation of the work of archaeologists working in California and Arizona, whose Spanish sites lingered even later than those in Texas did. They also have been looking for ways to refer to the later types (see Barnes 1980:192-110; Barnes and May 1972; Cohen-Williams 1992:119-130; May 1975).

The University of Texas at San Antonio Center for Archaeological Research (UTSA-CAR) is the curation facility for a large number of collections from Spanish colonial sites in Texas, which has facilitated the study necessary for producing this manuscript. The illustrations have drawn examples from these collections, plus a generous contribution from the large ceramic collection at Presidio La Bahía at Goliad. Much of the problem of identification is due to the small size of sherds recovered from most sites and, therefore, the difficulty of identifying types. Hopefully, these illustrations will help to fit a small sherd into the overall pattern of a type and from this to recognize comparative dating of deposits.

This is a step in the development of Texas archaeologists' ability to recognize and date ceramics from Spanish colonial sites. It is does not pretend to be the "be all and end all" on this subject. While primarily intended to be a manual for archaeologists working at Colonial sites in Texas, this publication will also serve as an introduction to Spanish colonial ceramics for those just beginning in historic archaeology in the state. 


\section{EDITOR's PREFACE}

The original ideal behind this manuscript was simply to publish a type manual of the Colonial Period ceramics present in Texas sites. The original type descriptions have been written some time ago but as the illustrations were compiled it never quite seemed that the draft was complete. As we began to think of what other sections a user of this manual would like to see, what other chapters may be useful to contextualize the types, the manuscript naturally grew with chapter added to provide a background for the Spanish occupation of Texas, ceramic manufacture in Mexico and methods of ceramic manufacture. Then it occurred to us that a reasonably comprehensive bibliography of archaeological investigations at Texas missions may also be of use to those readers intent on discovering more about Spanish colonial archaeology. By the time these ideas gelled and the product came together, we went from a manuscript of a few dozen pages to what you have here. I think all the additions were well worth the effort.

While we have tried to include the entire state in our discussion, the book is written from a South Texas perspective as these are the primary collections to which we have access and the sites with which we are most familiar. The manuscript is divided into four chapters. The first three chapters offer abbreviated background information. Chapter 1 is a brief history of the Spanish occupation of Texas, included to provide a background against which the details of ceramic types and dating will fit. Chapter 2 is a very brief summary of the history of Spanish ceramic manufacture in Mexico and a discussion of the importation of these ceramics into Texas. Chapter 3 provides a brief summary of the methods of manufacturing seen in Spanish ceramics in Texas, including the surface treatments and vessel forms. A glossary of terms used in ceramic analysis is included in Appendix A. Chapter 4 is the heart of the publication. It consists of type descriptions of Spanish colonial ceramics found in Texas. In most cases, each type includes a plate with several examples in color facing the text of the type descriptions. The layout is designed to facilitate identification. Each illustration will include the location at which the specific item was found, but in order to keep in-text citations to a minimum in Chapter 4, reference to the specific project during which each was recovered is not made. Instead, Appendix B consists of an extensive bibliography of archaeological site reports and artifact analyses, organized by location, for Spanish Colonial sites in Texas.

Steve A. Tomka 


\section{ACKNOWLEDGEMENTS}

Many people greatly helped in the completion of this volume. Special thanks go to the Florida Museum of Natural History for allowing us to use photographs of several ceramic sherds. The authors would also like to thank the individuals that provided their assistance throughout the process. Timothy K. Perttula, Kathleen A. Deagan, and Jack S. Williams provided insightful comments after reviewing a preliminary draft of the manuscript. Richard Young, Ross Rutherford, and Emmett Foulds put in a great many hours scanning and cleaning the images of the sherds we had in our collection. Bruce Moses prepared the final figures, tables, and maps for the publication. Marybeth Tomka assisted with locating sherds from the inhouse collection. The efforts of these individuals are greatly appreciated.

The authors would like to thank Susan Snow of the National Parks Service for allowing use of ceramic sherds from the San Antonio missions. Also, a thank you goes out to Presidio La Bahia for allow access to specimens from that site.

Finally, the authors would like to thank the director and staff of The University of Texas at San AntonioCenter for Archaeological Research for their support, guidance, and encouragement throughout the process of developing this work. 


\section{CHAPTER 1: Missions, Presidios, and Villas of Spanish TeXas}

The arrival of Columbus, and later Cortez, Pizzaro and their cohorts, altered both Native American and European cultures forever. With the Spanish came change. The Spaniards brought with them a distinct religion, new technologies, animals, food, unique customs, and disease. In exchange, the natives introduced the foreigners to indigenous resources and customs that created a blend that can still be observed today. Texas was subjected to these winds of change when the Spanish began their occupation by way of the many missions, presidios and settlements that they established throughout the region.

The first permanent Spanish settlement within the boundaries of the state of Texas is believed to have been founded in 1682 by Fray Francisco Ayeta. The mission, Corpus Christi de la Ysleta del Sur, was located east of present day El Paso. The last mission, Nuestra Señora del Refugio, established on the Mission River in what is now Refugio County, was secularized in 1830, some nine years after the end of Spanish rule in Texas (Tennis 2002:49). In the intervening 148 years, these institutions functioned as the centers of the Spanish colonization efforts in Texas.

\section{THE Beginnings}

Religious instruction of Central Mexico's native population by Spanish friars began almost immediately after the conquest of the Aztecs. The first group of Franciscan friars arrived in Mexico in 1524 (Ivey 1984:5). The formalized institution of the Spanish missions did not develop until late in the sixteenth century (Hinojosa 1991:65).

As their occupation expanded northward from Central Mexico, the Spanish found that not all Native Americans lived in settled farming communities controlled by a rigid social hierarchy such as the ones they had encountered in central Mexico. In central Mexico, the Spanish had merely replaced the uppermost level of a well-established hierarchy. The many semi-nomadic and nomadic groups they found in the mountains and deserts of what is now northern Mexico, which the Spanish collectively referred to as the “Chichimecas", were not as easy to subdue (Chipman 1984:49-50). Yet, the mines in territories such as Nueva Viscaya and Nueva Galicia had the potential to be highly productive (Hinojosa 1991:65) if the local Native populations could be brought under control. The Chichimecas, however, did not tolerate the presence of the Spanish, as was demonstrated in their fierce resistance during the Chichimeca War (15501590) (Chipman 1984:47, 49-51). 
To deal with the opposition, the Spanish considered extermination of the Chichimecas (Bannon 1974:5), but in 1585, the Franciscan bishops of the Third Mexican Council proposed another solution that did not involve destroying whole populations, whose labor was needed in the frontier (Ivey 1984:7-8; Poole 1965:130). They suggested establishing "Indian communities" (i.e. missions) in northern Mexico that would be supervised by Catholic Fathers from the interior of Mexico. The Spanish Crown would supply the friars' salaries and provisions, as well as that of the married soldiers accompanying the friars. The Bishop believed that the mission institution would demonstrate to the Natives the advantages of a sedentary and civilized life (Ivey 1984:8). This approach to colonizing the territory became one of the more common and peaceful modes of incorporating the Natives into the Spanish way-of-life:

And though some wilder tribes remained independent down to the nineteenth century, many of them were reconciled to Spanish rule not by military conquest but by the peaceful ministrations of the friars. In the north the friar anticipated the soldier instead of following him. Franciscans and Jesuits went fearlessly into the river valleys of Sonora and across the mountains of Chihuahua and Coahuila, building churches and gathering the Indians into mission, and frequently suffering martyrdom in retaliation for the crimes of military adventures (Parkes 1938:73).

In addition to the need to prevent violent resistance to Spanish occupation around the mining territories, the Spanish had another problem spurred by the geopolitical game between the Spanish and French empires. This problem was brought sharply to their attention in 1685, when they captured a French vessel in the Gulf of Mexico. Interrogation of those on board informed the Spanish that René-Robert Cavelier, Sieur de La Salle, had brought three additional ships full of colonists to establish a French military colony at the mouth of the Mississippi (Foster 1998:71). La Salle had landed far to the west of the Mississippi River, in Matagorda Bay on the Texas coast. Although his colony had already been destroyed by the time the Spanish found it in 1689 (Foster 1995:27) in what is now Victoria County, the Spanish realized that this would not be the end of French attempts to encroach on land the Spanish Crown had claimed. During the search for La Salle they had encountered several groups of Native Americans, some of whom, in particular the Hasinai, lived in small farming communities similar to those the Spanish had found in Florida and who had expressed an interest in more contact with them (West 1916:403).

The Spanish knew they needed to colonize the vast territory east and northeast of their established bases in Mexico and New Mexico in order to discourage any further French attempts at encroachment, but found a lack of interest from their own citizens to colonize. Instead, Spain had to examine other options. Unlike the English colonial powers, which aimed to displace or even eradicate the Native Americans, or the French, who wished merely to trade with the Native Americans they encountered, Spain worked to incorporate Native groups into their society (Hinojosa 1991:62). They wanted the Native Americans to 
become what they called gente de raison, "people of reason," by which they meant Spanish-speaking Catholics, citizens loyal to the Spanish Crown. To accomplish this they would use the method that had worked well in Florida, and to some extent in the Chichimeca territory and New Mexico missions.

\section{GOALS AND STRATEGY OF THE MisSionS}

The mission institution was developed for three main purposes: to protect, to Christianize, and to "civilize" (Fisher 1998:1). Missionaries were to be the cultural emissaries who established relations with native groups and founded far-ranging settlements that constituted the first step toward a Spanish foothold in the hinterlands. In this respect, the work of the Church served the purposes of religious zealots, military leaders, and the few European colonists alike, by converting the Native Americans to Catholicism and to a European lifestyle (McEwan 1993: xix).

In order to protect Spanish interests from French advancement in Texas, Spain focused on establishing a series of missions designed to incorporate Native groups into Catholicism and ultimately Spanish society. In 1537, Pope Paul III decreed that the Natives encountered in the New World were "truly men capable of understanding the Catholic faith," creating an opportunity for the clergy to spread Christianity to unexposed people (Fisher 1998:1). This strategy proved to be a successful solution in the case of the Spanish Territory of Florida, and Spain intended to create the same success story in Texas.

The presidial soldier regularly accompanied the missionary (Bannon 1974:68). The establishment of missions paired with a presidio propagated Spanish northern expansion. These two institutions provided a defended frontier with the labor force needed to undertake construction activities that would encourage subsequent colonization (Scurlock et al. 1976). The armed soldiers present at the presidio provided protection for the missionaries and sometimes provided the force necessary keep Native Americans from leaving. The soldiers also aided the priests in the education of the Natives (Hinojosa 1991:66-67).

Both institutions were only to remain in existence until the missionaries felt that enough Natives had been converted and educated. The plan was that missionaries would gather the natives into the mission complex, using abundant food as an enticement (Meissner 1999:40-41). There they could be instructed in the disciplines of religion, farming and a European way-of-life. Secularization would follow, and the land divided among the Natives. The mission and presidio would then be re-established at another location (Scurlock et al. 1976:19). Seeds planted through such expansion would hopefully make the territory more attractive to colonists from Spain (Fisher 1998:1). 
The missionaries of Florida did not find many sedentary agricultural societies flourishing throughout the land. Most of east Florida was occupied by hostile, nomadic groups which required some time to subdue and extract the obligatory labor and tribute (Deagan 1983:22). Similarly, the majority of the indigenous groups of Texas, with the exception of those living in East Texas and along the Rio Grande north of the Big Bend, were nomadic hunters and gatherers. They were not exposed to agriculture before the Spanish missionaries arrived and had not experienced a settled way of life.

The friars who came to Texas tried to apply the model that had been successful in Florida and sought to gather the natives into fixed settlements or reducciones. It was believed that sedentary living was the "Natural Law" (Hinojosa 1991:64). By having the natives live sedentary, agricultural lives, the missionaries were teaching the European lifestyle through example. Examples were insufficient, however, in convincing the inhabitants, even those who had established a sedentary lifestyle before the Spanish occupation, to remain permanently within the missions and the friars constantly complained of fluctuations in resident populations. One missionary explained to the Viceroy:

In this province, one cannot found a mission, nor resurrect those that have been abandoned in the same way that Mexican settlements are established, where the Indians, prior to their conquest, already lived in society, with some of the cleanliness, and with commerce between the kingdoms. With the nations of the north, it is impossible because they live dispersed in their heathendom, without loyalty to any monarch, since they have none. These nations have no fixed abode and are always wandering about. [Fr. José Mariano Reyes to the Viceroy, May 1, 1770, translated by Ricklis (1996:159)]

\section{Site Plan}

The structured layout of many of the Texas missions resembles 12th Century Benedictine Monasteries (Ivey1984:13). These Monasteries retained all that was essential to be self-sufficient. Though the monks who resided in the Benedictine Monasteries lived scheduled lives isolated from the outside world, Franciscan friars who sought out individuals to convert and instruct ran the missions. The layouts of the

missions resemble the plan of St. Gall, a "perfect" plan according to the Rule of St. Benedict (Ivey 1984:2). The Rule of St. Benedict required that "the monastery should be laid out that everything essential, that is to say water mills various crafts, is found with the Monastery walls" (Ivey 1984:2). The Monasteries clustered around the main church, living quarters, the kitchen, the refectory, storage rooms and the "chapter house" (Ivey 1984:2). Other buildings within the complex included workshops (smith, cooper, ceramic, textile, etc.), infirmary or hospital, a bakery, a grist mill, barns, stables and even areas for the wine making and beer brewing (Ivey 1984:2). Outside the structural compound of the mission, were farmland and pastures. 
The mission complexes were similar to the Benedictine Monastery with a few minor exceptions. The convento of the mission is actual a collection of some of the previously discussed rooms; the friars quarters, infirmary, privy, kitchen, refectory, and certain work areas. The missions allowed for textile workshops, stonemason, blacksmith and carpenter shops, as well as, granaries and native housing within the compound (Ivey 1984:4-6). Like the monastery plans, the farmlands and pastures were also located outside the structural complex at the missions.

Before construction of a mission compound, the site under consideration had to fulfill several requirements. The highest priority, exceeding even the proximity of local Indian groups, was water. Native Americans could always be brought to a mission site, but water obeyed specific physical laws that dictated where it could be used (Ivey 1984:7). Where irrigation was needed to bring water to farmland, pasture land, and the mission nucleus, other factors such as a bank height, slope, water flow, and valley contour had to be examined before the site could be deemed acceptable (Ivey 1984:8). The site also needed to have areas that were level, water accessible, and above flood levels for croplands. Adequate pastureland was needed for grazing livestock and availability of resources for building and fuel (i.e. wood, clay, limestone, gravel, etc.) were other requirements.

\section{SPANiSh EFForts to COLONize TeXAS}

On several occasions during the $16^{\text {th }}$ and $17^{\text {th }}$ centuries, brief exploration of the Texas frontier occurred. Cabeza de Vaca's journey through Texas did not begin with the intended purpose of surveying the Texas territory; rather, he was part of a crew trying to investigate the Florida Gulf Coast that got separated from the rest. He spent seven years on the Texas frontier before returning to Mexico. Other expeditions briefly ventured into Texas territory, but usually with the intended purpose of finding easier routes to present-day New Mexico. The first real settlements in Texas began with Spanish missions and presidios.

The timing and locations of the missions established in present-day Texas reflect both geographical factors and concerns about the French encroachment into regions neighboring Texas. Figure 1-1 is a map showing the locations of all the known Spanish missions, presidios, and secular communities in Texas. The sites are grouped into missions and presidios and are numbered from west to east across the state. 


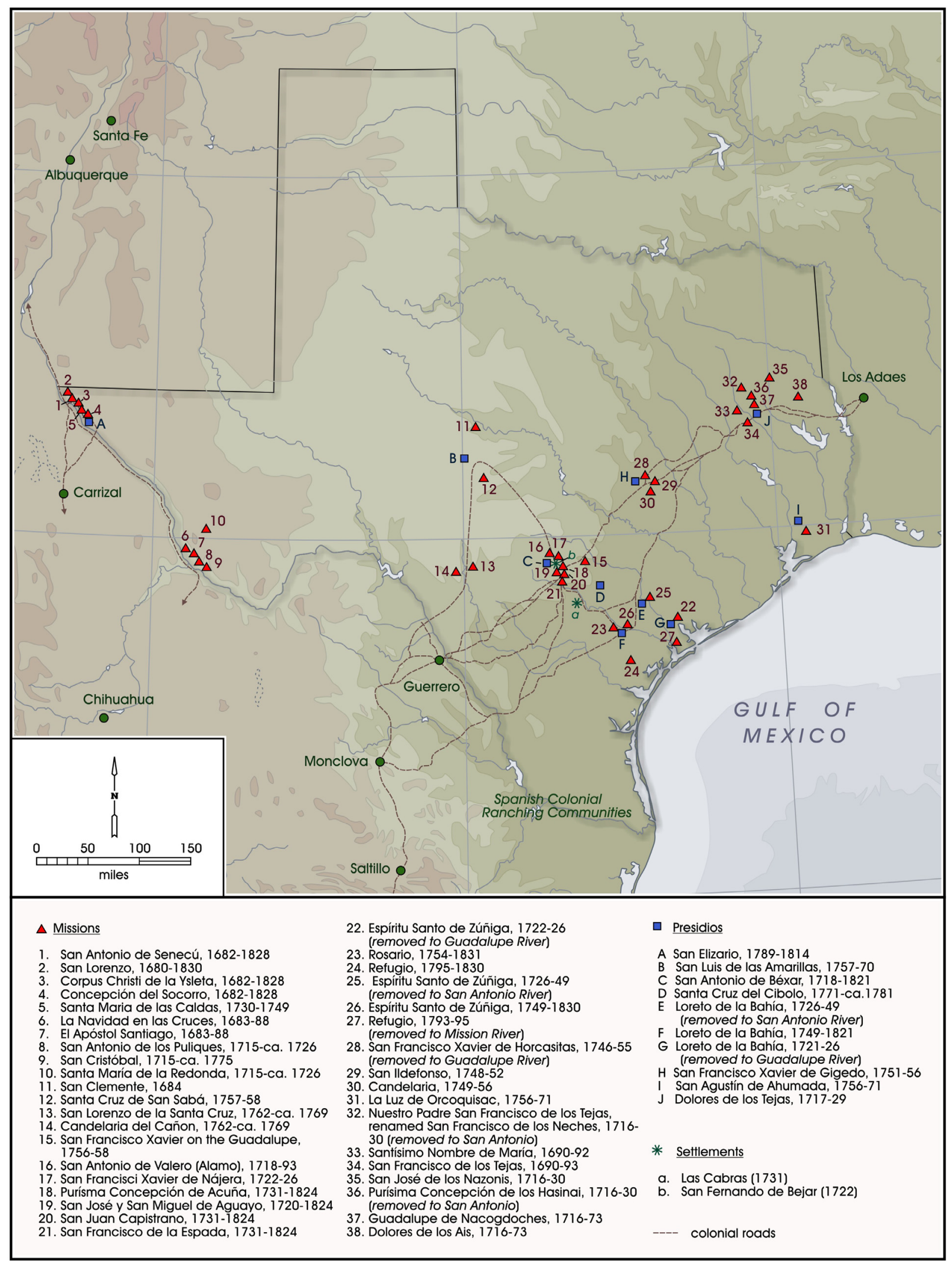

Figure 1-1. Map showing locations of known Spanish Colonial Sites. 
From a chronological and geographic perspective, the Spanish settlement of Texas resulted in five waves that established missions in: 1) West Texas, in and near what is now El Paso and Presidio; 2) East Texas, where the Spanish hoped to find allies against the French in the indigenous population; 3) San Antonio, which could provide a secure way station between the Rio Grande and the East Texas missions; 4) Central Texas, where attempts were made to Christianize the Apaches; and 5) the Gulf Coast. The West Texas missions represent the earliest permanent settlements in Texas and date to the late $1600 \mathrm{~s}$. The East Texas missions were established during the early 1700s in response to the perceived French threat, while the several San Antonio mission represented a strong push, between 1718 and 1731, to colonize the new frontier. The Central Texas missions were highly unsuccessful attempts that took place between 1740 and 1770 to end the predations of the Apaches and other "Norteños" by settling them in missions. With one exception, the Coastal missions came relatively late in the history of colonization of the state and reflect both concerns with re-establishing Spain's claim to the area in the face of the French threat as well as reducing threats from the natives groups of the region.

Below we present a brief summary of regional histories in mission establishment and refer to specific missions to illustrate those trends. For the reader that is interested in learning more about these missions and trends we recommend that they consult some of the several authoritative works including Habig (1968a, 1968b, 1990), Bannon (1974), and Chipman (1984).

\section{West TeXas Missions}

In 1659, two Franciscans from New Mexico, Fray Juan Pérez and Fray Juan Cabal established a small church near El Paso de Norte, near present day Cuidad Juarez, which developed into Mission Nuestra Señora de Guadalupe (Chipman 1992:66; Weber 1992:91). Though the mission was not placed within the modern Texas boundary, several of the native groups serviced here were from east of the Rio Grande. The first permanent Spanish settlement within the Texas state boundaries is believed to have been founded in 1682 by Fray Francisco Ayeta. The mission was named Corpus Christi de la Ysleta del Sur (Figure 1-1: 3), in honor of the refugees from Ysleta who congregated there. The mission was located east of present day El Paso. During the next 50 years four additional missions were built in the El Paso/Socorro area (Habig 1990). As shown in Figure 1-1, these included San Antonio de Senecú del Sur (1), San Lorenzo (2), Nuestra Señora de la Limpia Concepción de Los Piros de Socorro del Sur (4); and Santa María de las Caldas (5). All of these missions were affected by a major flood of the Rio Grande in 1829. Corpus Christi de Ysleta, Concepción del Socorro and San Antonio de Senecú were all originally established west of the Rio Grande, but the flood in 1829 destroyed San Antonio de Senecú, Concepción del Socorro, and San Lorenzo, and created an island containing Corpus Christi de Ysleta east of the new 
main channel of the river, moving it into what became Texas. Corpus Christi de Ysleta and Concepción del Socorro were rebuilt, and then rebuilt again on higher ground after an 1840 flood. These churches are still used today (Habig 1990:149). Santa María de las Caldas was originally built for the Suma people, and was always an open community, more similar to the missions in New Mexico than the walled fortresses of Texas (Wright 2001). It existed from 1730 to 1749 (Habig 1990:166).

Southeast from the El Paso missions along the Rio Grande, several missions were established near present day Presidio. Navidad en las Cruces (Figure 1-1: 6) (also known as San Francisco de los Julimes) was established in 1682 for the Jumanos who requested the mission (Habig 1990). The mission existed for one and a half years before the Franciscan missionary was forced out by the aggressive natives. It was reestablished in 1687 for a short time. Soon after Navidad en las Cruces was founded, two Franciscan missionaries founded El Apostol Santiago (Figure 1-1: 7) at another church constructed by the Jumanos, located further south. The missionaries were forced to leave this mission approximately six months later. It is possible that the mission had a brief resurgence in 1687 (Habig 1990).

Attempts to re-establish missions in the Presidio area were made in 1715. Mission San Antonio de los Puliques (Figure 1-1: 8) was founded near the site of present-day Presidio (Habig 1990:153-154). Some speculate that the mission may have had its start sometime during the $1680 \mathrm{~s}$, though this may be due to the fact that Mission San Antonio was placed near or on the site of El Apostol. Mission San Antonio de los Puliques lasted until 1795, though it was abandoned several times for periods of up to six years. Another mission founded in the area during 1715 was San Cristóbal (Figure 1-1: 9). Habig (1990:154) reports that the mission's history was similar to that of San Antonio de los Puliques, although other sources believe that it was initially started in 1683, and given its name in 1715 (Burke 1971:63-64).

Mission Santa María la Redonda de los Cibolos (Figure 1-1: 10) was located approximately twenty miles north of Presidio near Cibolo Creek. Little is known about this mission. It appears to have been established by the Trasviña Retis expedition in 1715, but it is possible that it was founded in 1684 by the Dominguez Mendoza expedition. Regardless, the mission was abandoned in 1724 (Habig 1990:154).

\section{EAST TEXAs MisSIONS}

The Aguayo expedition of 1689 to East Texas in search of the La Salle colony found that the settlement, known as Ft. Saint Louis, had already been destroyed by a smallpox epidemic and by hostile Native Americans (West 1916:398). Some of the Native American groups living inland from Fort Saint Louis had expressed interest in maintaining contact with the Spanish, which made the latter believe they would be willing to enter a mission (West 1916:403). 
The Spanish returned to East Texas in 1690 to establish Mission San Francisco de los Tejas (Figure 1-1: 34) and Santísimo Nombre de Maria (Figure 1-1: 33) along the Neches River. Texas was officially created as a frontier province in 1691, with Domingo de Teràn named as governor. Teràn found the Caddo Indians in the area were not eager to enter the missions (Bannon 1974:102). The two missions did not last long. The first existed three years before missionaries and soldiers abandoned the site at the urging of the Caddo. Rumors of an invasion by the French caused the Spaniards to bury any large valuable items and burn the structures to the ground before retreating to Coahuila (Burke 1971:118). Santísimo Nombre de Maria was even less successful, lasting roughly one and a half years. A flood washed away the straw chapel and the missionaries fled to San Francisco de los Tejas (Habig 1990:153).

In 1713, the French constructed Fort Natchitoches on the Red River under the instruction of Louis Juchereau de Saint-Denis. This prompted Spain's second attempt to secure East Texas in 1716 (Bannon 1974:111). By July of 1716, four Spanish missions and Presidio Nuestra Señora de las Dolores de los Adaes (located in what is now Louisiana) were founded not far from the French fort. San Francisco de los Tejas was restored six miles from the original site and rechristened Nuestro Padre San Francisco de los Tejas (Figure 1-1: 32). As shown in Figure 1-1, the new missions were Nuestra Señora de la Purísima Concepción de los Hasinai (36), Nuestra Señora de Guadalupe de los Nacogdoches (37) and San José de los Nazonis (35). Two more missions, Mission San Miguel de Linares (in present day Louisiana) and Nuestra Señora de los Dolores de los Ais (38) were added the next year to provide a better defense against the French (Burke 1971:70). The French presence in Texas had been met and Spanish presence in the area had been established "...but it was immediately evident that it could be held only if strong reinforcements, military and civilian, came up from Mexico and quickly" (Bannon 1974:116). Sickness and dissention reduced the population at the East Texas missions and presidio leaving them vulnerable to Indian revolt or French invasion. It was clear that the settlements needed assistance in 1719, when these missions were all abandoned after the French attacked Presidio los Adaes (Burke 1971:70). Most of the Spanish fled to Mission San Antonio de Valero (Figure 1-1: 16), which had been established the year before on the San Antonio River (see below).

By 1721, the threat of French encroachment lessened. Marquis de San Miguel de Aguayo was sent to East Texas to push the French out, but he found them willing to go without a fight (Hackett 1945). He reestablished the missions and built a new presidio, Loreto de la Bahía (Figure 1-1: E) on the site of La Salle's Fort Saint Louis.

By 1729, however, Spanish officials were convinced that the East Texas missions were too costly to maintain and their presence was no longer needed. The Hasinai and other Caddo groups had not been 
receptive to the Spanish missions (Bannon 1974:102). French attempts at occupation of the area had ended in 1721, so they no longer posed a threat to Spanish territory. Only Mission Guadalupe de los Nacogdoches (Figure 1-1:37) and Dolores de los Ais (Figure 1-1:38) were to remain in East Texas. The other three, Concepción de los Hasinai (Figure 1-1: 36), San José de los Nazonis (Figure 1-1: 35), and Nuestro Padre San Francisco (Figure 1-1: 32), were moved, first briefly to a location on the Colorado River not far from modern Austin, and then to the San Antonio River, where each was renamed. The two remaining missions in East Texas were finally abandoned in 1773 (Burke 1971:70; Habig 1990:156-157).

The missions of East Texas faced several problems that limited their impact on Native American culture and ultimately led to their failure. Even though they were already living a sedentary life in small farming communities the Caddo were not interested in joining the missions. In addition, the distance that supplies from Mexico had to travel (Scurlock et al. 1976:23; Bannon 1974:121) to reach the missions often lead to shortages in resources that would discourage full-time residence at the missions.

\section{The SAn ANTONIO Missions}

In 1709, an expedition led by Captain Pedro de Aguirre stopped briefly near the headwaters of the San Antonio River (Foster 1995:99). Accompanying Aguirre on the expedition was Fray Antonio de San Buenaventura Olivares. Fray Olivares was greatly impressed by the abundance of resources, ideal locations, and disposition of the natives found near the Rio San Antonio. Olivares began petitioning to be allowed to move the rapidly failing Mission San Francisco de Solano across the Rio Grande (de la Teja 1995:8; John 1975:206-207) to this place where the creeks were "bordered by many trees and with water enough to supply a town" (Tous 1930:5). Before the end of 1716, the Governor of Coahuila commissioned Olivares to found a mission along San Antonio River (Bannon 1974:117). On May 1, 1718, Mission San Antonio de Valero (16) was founded (Foster 1995:132). Five days later Presidio San Antonio de Béjar (C) was established nearby (Bannon 1974:117). This Spanish community on the San Antonio was intended more to provide a secure way station on the road to the East Texas Missions than to convert the local Native Americans (de la Teja 1995:7).

Mission Valero (Figure 1-1: 16) was originally located just west of San Pedro Springs. The young mission experienced several setbacks at its first location. The mission was moved to the east side of the river in 1719 (Habig 1990:159). This second location did not fare much better as in 1724 a hurricane destroyed what few buildings had been erected at the mission. After the devastating hurricane passed, Mission Valero was moved to its present-day location across the river from the Presidio San Antonio (Figure 1-1: C). Mission Valero was initially successful, with the Native population reaching 328 by 
1756. The mission served many groups of Native Americans from all areas of Texas. These groups included the Payaya, Tacame, Xarame, Apache, Coco, Karankawa, Ervipiame and Yuta (Schoelwer 2006).

When the fears of French aggression led to the first abandonment of the missions in East Texas during 1719, many of the missionaries came to Mission Valero for refuge. One of them, Fr. Margil de Jesus asked permission to establish a second mission, San José y San Miguel de Aguayo (Figure 1-1: 19) in 1720. The original location of Mission San José was the east bank of the San Antonio River, approximately three leagues from Mission Valero. Its location changed to the opposite bank sometime between 1724 and 1727. The mission moved to it present location during the 1740s due to an epidemic (Scurlock et al. 1976:222).

In 1722 Mission San Francisco Xavier de Nájera (Figure 1-1: 17) was established, probably on the original site of Mission San José (Ivey and Fox 1999:45). The mission served a group fifty Ervipiami families that came from the Brazos River area. It appears that a shortage in funding created the decline of the mission and it lasted only about two years (Habig 1968a:78-81), although it is possible that the decline was due to a lack if interest on the Native's part (Ivey 1984:13). The mission closed in about two years but it was reopened shortly thereafter in an attempt to have it serve as a sub-mission of Valero. This trial did not last long (Habig 1968a:78-81) and its doors closed for good in 1726 (Schuetz 1968:11).

The year 1731 proved very eventful in the area. Three East Texas missions relocated to the San Antonio vicinity in March and the civilian town of Villa de San Fernando de Béjar was established across the river from Mission Valero near the location to which the Presidio San Antonio de Béxar (Figure 1-1: C) had been moved (Scurlock et al. 1976:22). San Fernando de Béjar was established on March 9, 1731, but did not receive viceregal approval until October (Scurlock et al. 1976:22). The villa expanded throughout the eighteenth century, with both immigrants from Mexico and Native Americans who had been baptized and married into presidio and villa families forming the population (Scurlock et al. 1976:22).

As the villa grew, the three East Texas missions were busy settling in their new locations. Each mission was re-christened upon arrival along the San Antonio River. Nuestra Señora de la Purísima Concepción de los Hasinai (Figure 1-1: 36) was renamed Nuestra Señora de la Purísima Concepción de Acuña (Figure 1-1: 18); Mission San José de los Nazonis (Figure 1-1: 35) became Mission San Juan de Capistrano (Figure 1-1: 20); and Mission Nuestra Padre San Francisco de los Tejas (Figure 1-1: 32) was renamed Mission San Francisco de la Espada (Figure 1-1: 21) (Scurlock et al. 1976:22-23). 
The early years of the San Antonio missions saw much hardship and struggle. Though there were adequate resources of wood, quarry stone, and water, fields had to be irrigated to be used as croplands. This necessity limited the areas that could be settled around San Antonio: “...The fields required irrigation and this could be accomplished only in a narrow area along the upper 10 miles or so of the valley" (Ivey 1984:4). A major difficulty the missions faced was that, unlike the Native Americans surrounding the West Texas and East Texas missions, the Natives inhabiting South Texas were hunters and gathers who would have to be convinced to give up their nomadic ways (Schuetz 1968:14). The need to provide a large and dependable food supply to entice Native Americans into the missions led to the building of an extensive acequia system to provide irrigation to the fields around each mission (Cox 2005). In addition, large tracts of land surrounding San Antonio were pulled into service as ranches to raise large herds of cattle (Cargill et al. 1998).

The population census data of the missions reveal that initially there was no problem enticing the natives to join the missions. The prospect of abundant food, supplied by irrigated fields and the rapidly increasing herds of cattle, sheep, goats and pigs, as well as acquisition of material objects such as metal tools and glass beads, was an important lure to the missions, but protection from other Native Americans, especially Apaches, and later, Comanches, may have been an even greater inducement (John 1975:255-257; de la Teja 1995:9). However, even with these inducements, the Natives often did not stay (Ricklis 1996:159162; Schuetz 1968:14). One father noted "It is the exception who does not flee to the wilderness two or three times and so far away that sometimes they go as far as 100 leagues away" (Habig 1978:56). At first, those who left and those who died of disease were readily replaced. Valero and San José, the first two missions established, had a neophyte population of over 500 by the end of the 1720s. In 1740 the overall Native American population of the missions was 987 (Habig 1978:80), but by 1750 the combined missions population was declining. All five missions housed only about 800 Natives (Hinojosa 1991:62). In 1789, Fray Lopez noted that although Mission Valero was now some 70 years old, the majority of the population there had converted as adults (Habig 1968a:65). Hinojosa (1991:75) has pointed out that over two-thirds of the 319 Native Americans who were identified in both baptism and death records died before the age of three. Only eight from this group lived to the age of 30 . No population growth within the mission community was taking place.

Historical records reveal much concerning the subsistence of the inhabitants of the missions. Farming and ranching endeavors were given much attention, “...types and quantities of vegetables and grains cultivated, the location and structure of the rancho, and the number of horses, sheep, pigs and mules and chickens" (Scurlock 1976:23-24). In Padre Dolores' account of mission life he wrote: 
There are consumed for this cattle which they try to increase to kill for them in each mission each Sunday and some special feast days, four or five heads of cattle butchering them, according to the number of people, making the pieces for each individual according to his ration, and mutton is given when they are sick. The maize from the harvest is used by giving it to Indians that they need to their complete satisfaction, also they issue beans, squash, watermelons which in each mission there is care to plant annually, for this produce is a major gift for the appetite of the Indians (Schuetz 1968:20-21).

Evidence suggests the use of indigenous food resource as well. An account from an anonymous missionary from Mission Concepción states "some women are in the habit of leaving the mission toward evening to eat tunas, strawberries, sour berries, nuts, sweet potatoes and other fruit and roots from the field" (Luetenegger 1976:49). Catching fish from the irrigation ditches was not uncommon either (Schuetz 1980:205). Some padres exhibited culturally biased views in their accounts of the natives' use of indigenous foods: "common illness [es] were fatal to the natives because they ate unwholesome foods gathered in the el Monte (wilderness) nearby" (Hinojosa 1991:76).

The early mission sites did not boast the impressive structural remains that we see today. In fact, original mission structures were very rudimentary. The buildings were constructed of cedar posts, thatch roofs, adobe walling and lime or mortar flooring (Ivey 1984:37; Scurlock et al. 1976: 23). Permanent stone structures at four missions began to be constructed during the 1740s and 1750s. Great care was taken in the construction of the churches, often taking up to 15 years to complete one project. All the missions had a stone church building by the mid 1750s. Mission San José was the exception, with an adobe church finished in 1749, and a stone church was not even begun until 19 years later (Scurlock 1976:23).

The institution of the frontier mission was originally believed to be a temporary means of Christianizing and Hispanicizing indigenous cultures. The missions were only to remain functioning until it was deemed that the people could be integrated into Spanish society. The San Antonio missions did not work towards this goal:

As for assimilation of the Indians into the Hispanic society of San Fernando, it does not appear to have been seriously considered. Quite the contrary, the work and life in the mission and the building programs directed by the padres were designed to create permanent communities completely separate from the other institutions on the frontier. The survival and development of the missions for almost a century attests to the strength of those ideals of segregation and independence (Hinojosa 1991:69).

The San Antonio missions may have received support from both religious and political sects; for the most part, they acted in total isolation from the urban San Antonio society (Hinojosa 1991:68-69; Ivey 1984:1). 
Secularization of the San Antonio missions began in 1793 (de la Teja 1995:86). Mission Valero and Mission San Juan were fully secularized in that year. Final secularization occurred at Mission Concepción in 1823. Secularization was completed in 1824 at Mission San José (Habig 1968b:122). In September 1831, all of the remaining Mission Espada lands were ordered to be auctioned.

\section{Central Texas Missions}

Several clusters of missions were founded in Central Texas, north and east of San Antonio. Many of these missions were established in an effort to serve the Apaches, though much of their work was not successful.

As shown in Figure 1-1, three missions were founded along the San Gabriel River between 1746 and 1749. Mission San Francisco Xavier de Horcasitas (28) was the first organized in 1746, though it was not officially established until 1748. The mission was not very successful due to the squabbling between the Natives and the presidio soldiers, a yearlong drought, and the murder of the missionary at Candelaria (Burke 1971:72). The mission functioned at this site until 1755 when it was moved to the springs at San Marcos where it lasted for a year before being moved yet again to the last site in present-day New Braunfels. After the last move, the mission was referred to as San Francisco Xavier on the Guadalupe (15), or just the Guadalupe Mission (Chipman 1992:849; Habig 1990:173). The mission was never formally recognized at its final location, but Father Dolores campaigned to include the site among the missions supported by Pedro Romero de Terreros. Terreros was encouraging the founding of missions among the Apaches, and the Guadalupe Mission fell outside of that region. Due to lack of funding and protection from a presidio, the mission was abandoned in 1758 (Chipman 1992; Habig 1990).

Soon after the establishing of Mission San Francisco, Mission San Ildefonso (29) was founded approximately two miles east of the first mission. It was hoped that this mission would serve the Coco, the Mayeye, the Orcoquiza, and other local groups. A smallpox epidemic, combined with a drought and the murder of Fr Ganzábal at Mission Candelaria (Burke 1971:80-81), caused a decline in the native population of the mission.

The third mission established along the San Gabriel River was Mission Nuestra Señora de la Candelaria (30). The mission was founded in 1749 and had some success in the beginning. Troubles brewed, nonetheless, between the presidio soldiers and the native inhabitants. The decline of the mission was set off by a double murder that appears to have been orchestrated by Captain Felipe de Rábago y Terán. Terán had been admonished by Father Miguel Pinella and Father Juan José Ganzábal on several occasions for his harsh punishments of the natives, and the refusal to order his soldiers to conduct themselves in a 
more appropriate manner with the native women. To add to the ill behavior of Terán and his soldiers, an affair between Terán and the wife of one of his enlisted men, Juan Joseph Ceballos, came to light. Ceballos, unhappy with Terán's behavior, went to the padres for guidance. Ceballos had publicly denounced Terán, who imprisoned Ceballos for his actions and continued his affair. Fr. Ganzábal petitioned for the release of the prisoner, which induced Terán to punish Ceballos further. Infuriated, Fr Ganzábal threatened to report the incident to the superiors. Terán released Ceballos to appease Ganzábal, but was still filled with anger toward the priest. A few days later, on May 11, 1752, Fr Ganzábal and Ceballos were murdered while having dinner in the priest's room. A member from the Cocos confessed to the murders, though provided additional information implicating Terán. Within the next four years, the mission experienced a rapid decline in native inhabitants, brought on by their lack of faith in the Spaniards. In 1755, the mission was moved to San Marcos, and was deserted within the year (Burke 1971; Habig 1990; Richards 1936).

The establishment of Mission Santa Cruz de San Sabá (Figure 1-1: 12) in 1757 was another attempt to establish a mission for the Apaches. San Sabá was placed approximately three miles east of present-day Menard. Temporary structures were quickly erected at the mission and a protective stockade was built surrounding the complex. Presidio San Luis de las Amarillas (Figure 1-1: B) was established nearby in 1757. The Apaches who were to enter San Sabá were apprehensive due to persistent rumors of attack by their enemies to the north, including Comanches and Caddos. The rumors proved true in 1758, when a large gathering of Comanches arrived at the mission's gate. Among them were some Hasinai Caddo, who tricked the padres into opening the gate by insisting they were on a friendly visit. Soon after the gates were open, the invading natives massacred the padres and many of the soldiers at the mission. After they collected all that was transportable, the structures were burned. The attackers left before any assistance from the local presidio was organized. Attempts were made to re-establish the mission; however, none were productive (Burke 1971:134-137; Habig 1990:175). The presidio, later known as Presidio San Sabá, remained working until 1771 (Habig 1990:185).

Four years after the demise of Mission San Sabá, another attempt to Christianize the Apaches was undertaken near the present site of Camp Wood, along the Nueces River. Mission San Lorenzo de Santa Cruz (Figure 1-1: 13) was founded in 1762 with the help of soldiers from the Presidio San Luis. Efforts were made by the Apaches' enemies to keep the mission from becoming established. San Lorenzo experienced a little more success than Mission San Sabá, but ultimately the mission failed and was abandoned in 1770 (Habig 1990:176). In the same year that San Lorenzo was established, Nuestra Señora de la Candelaria del Cañon (Figure 1-1: 14) was founded approximately ten miles south. The mission existed for approximately six years before consolidating with San Lorenzo (Habig 1990:176). 


\section{COASTAL MisSiOnS}

Several missions were established along the Texas Gulf Coast to administer to the Aranama, Karankawa, Orcoquiza, and Bidai groups. In 1721, the Marques de Aguayo, having negotiated the withdrawal of the French to Louisiana, established a presidio, Loreto de la Bahía (Figure 1-1: G) on the site of La Salle's Fort St. Louis, on Garcitas Creek (Hackett 1945). The next year Mission Nuestra Señora Espíritu Santo de Zúñíga (Figure 1-1:22) was founded approximately two miles north of the presidio. In 1726, a conflict between the natives led the Franciscan missionary to move the mission to a new location believed to have been in present day Victoria. The exact locations of the early sites of the mission have been the subject of debate for some time (Walter et al. 2006a). It is not known how long the second location of Espíritu Santo (Figure 1-1: 25) was occupied after the mission was officially moved to the Guadalupe River later the same year. Archaeological research suggests that the mission may have been in use until the move to the final location on the San Antonio River near Goliad in 1749 (Figure 1-1: 26) (Walter et al. 2006a). This final location of the mission served the Aranama, and prospered in ranching endeavors. As the location did not allow for irrigation, farming was never successful. Often, the San Antonio missions sent vegetables and fruit to sustain Espíritu Santo and Rosario (Figure 1-1: 23). The women at Espíritu Santo were well known for their pottery making skills (Walter et al. 2006b). The mission began secularization in 1802, with complete surrender of the church in 1830 (Burke 1971:124-126; Habig 1990:166).

Just across the San Antonio River, approximately four miles west of Espíritu Santo, Mission Nuestra Señora del Rosario (Figure 1-1: 23) was established for the Karankawa in 1754 (Habig 1990:174). The mission was quickly moved to a higher location soon after it was founded. The need for Rosario was due to the animosity between the Karankawa and the Aranama. Similar to Espíritu Santo, farming was only possible when the weather was favorable. Irrigation was not possible due to the contour of the land, however, the mission was successful in cattle ranching. Rosario was abandoned by 1780, and accounts indicate that the Karankawa were not happy with their treatment by the Spanish missionaries and soldiers (Fox 2000:5). The Karankawa returned in 1789 for a brief revival of the mission. The period was marked by peaceful relations between the Natives and the Spaniards. By 1791, a new church was built of stone. The mission continued until 1808, when the mission inhabitants were moved to the newer mission of Refugio (24), although there is evidence that at least some Native Americans remained at the mission until about 1830 (Fox 2000:6; Habig 1990:174).

Nuestra Señora de la Luz de Orcoquisac (Figure 1-1: 31) was founded in 1756 across the bay from present-day Houston. The mission was intended to serve the Orcoquiza and Bidai tribes of the area. Two years before the mission was founded, a Frenchman was arrested near the mouth of the Trinity River. To 
reassert Spain's claim to the area, Governor Jacinto y Juaregui pushed for the establishment of the Orcoquisac Mission. Conflicting accounts speak of the mission as a success and as a failure. The mission persisted until the closure of the Presidio San Agustín de Ahumada (Figure 1-1: I) in 1770. The mission possibly continued one to two additional years before abandonment (Burke 1971:78-79; Habig 1990:174; Wooster 1996:1069).

The last mission in Texas, Nuestra Señora del Refugio (27), was established on the eastern shore of Guadalupe Bayou in 1793 (McDonald 2002:14-15). It soon became clear that the first location was not well chosen. It was inaccessible during long periods, when almost continuous rains left it surrounded by water and mud. The massive numbers of mosquitoes were intolerable. Most importantly, the mission was completely vulnerable to attack by Natives (McDonald 2002:20-21). Refugio was moved to the Mission River in 1795 to the site of the present Our Lady of Refuge Catholic Church in Refugio, Texas. Here the mission persisted, with the inhabitants constructing a stone church and convento by 1809 . Missions Rosario and Refugio were combined in 1808 and all the remaining inhabitants of Rosario moved to Refugio. Many of the mission buildings were badly damaged in a hurricane in 1818 (McDonald 2002:53). In 1824, the mission was ordered to close, with all possessions being transferred to La Bahía. The mission continued to serve the remaining natives until 1830, when the mission was officially abandoned (Benowitz 1996:1073; McDonald 2002:66-67). Mission Refugio was the last Texas mission created and the last mission abandoned.

\section{PRESIDIOS}

The construction of presidio complexes often occurred simultaneously with the establishment of the Spanish missions. The presidios offered added protection to the mission inhabitants, as well as providing opportunities for colonists to brave the frontier. Regulations stated that settlers were not to be turned away at the presidios, rather, they were allowed inside the wall to sell their wares, given parcels of land to produce crops, and encouraged to help in the defense of the settlement with the presidial soldiers (Moorehead 1975:270). The presidios would often be placed within close proximity of the missions, usually on the other side of a river, so as to be near enough to supply aid when needed, but far enough to offer some obstacle to the soldiers' access to the missions' female neophytes. One presidio may serve anywhere from one to five missions at a time.

The population at each presidio varied in the number of individuals and the ethnic background. As the mission period progressed in Texas, the ethnic dynamic shifted frequently. Some presidios were manned by individuals of purely Spanish background (i.e. espanoles, europeos), with a few members who were 
considered mixtures (mestizos, mulatos, coyotes, etc.) and some members of the local native groups considered to be scouts (exploradores) (Moorehead 1975:182-183). At the presidios on the frontier, the ethnic Spaniards were usually outnumbered by the men of mixed background and acculturated Native Americans (Moorehead 1975:197-198).

Eight presidios were established in Texas (Figure 1-1). These included San Elizario (A), San Luis de las Amarillas (B), San Antonio de Béxar (C), Santa Cruz del Cíbolo (D), Loreto de La Bahía (E, F, G), San Francisco Xavier de Gigedo (H), San Agustín de Ahumada (I), and Nuestra Señora Dolores de la Tejas (J). Each presidio played a specific role in the development and protection of the Texas frontier.

The first presidio established within the present State of Texas was Nuestra Señora de los Dolores de los Tejas (Habig 1990:178-180). The presidio was founded in 1716 to serve the missions of Nuestro Padre San Francisco, Concepción de los Hasinai, San José de los Nazonis, Guadalupe de Nacogdoches, and Dolores de los Ais. The presidio was moved a few times before settling along Thomas Creek, but the exact location of these sites is not known. Presidio Dolores not only acted to protect the missionaries and their neophytes from raiding natives, but also as a listening station to track French activities in the area (Faulk 1996:334). The presidio lasted until April of 1729 when it was ordered to close (Habig 1990:180).

The presidio of San Antonio de Béxar was first erected at San Pedro Springs, near the San Antonio River in 1718. The exact location of this presidio is not known, though it was likely on the hill above the springs. The complex consisted of an adobe house that served as a headquarters, while the soldiers resided in huts. In 1722, the presidio was moved to a location on the west side of the river where it would serve as the nucleus around which the secular settlement of San Fernando would later develop. The new structures were to be built of adobe bricks, but documents indicate that they were never completed. Unlike the other presidios in Texas, San Antonio de Béxar lacked any substantial structures such as walls, or towers. The compound was enclosed by a stockade, though the soldiers continued to live outside the walls within the town (Faulk 1996:334). The few structures fell into disrepair, and by 1790, new plans to reconstruct the presidio were created. These plans were never followed through. The Segunda Companía Volante de San Carlos de Parras del Alamo arrived in 1803 to help protect the town from hostile Native Americans, but they chose the recently abandoned buildings of Mission Valero, across the river from the town itself, giving it a new name: the "Alamo." The soldiers utilized the abandoned mission structures as the center of the fortified defense, and the plazas surrounding San Fernando as the municipal center. The old presidio in the center of town witnessed much of the hostility during the Mexican and Texan fights for independence. The presidio had a very brief reinstatement after the fall of the Alamo, but was finally closed in 1836, after Texas won its independence (Handbook of Texas 1996:826). 
Presidio Santa Cruz del Cíbolo was built on Cibolo Creek in Karnes County on the site of a small fort "Fuerte Santa Cruz del Cíbolo" that had been maintained there from 1734 to 1737 to protect the horse herd of Presidio San Antonio. The little fort had failed and was abandoned, but in 1771 a full-scale presidio was built on the site to protect the road from San Antonio to Mission Espíritu Santo and Mission Rosario in Goliad. Almost constant hostilities with Apaches and later Comanches became much worse by the early 1780 s and in 1782 the men were returned to San Antonio and the presidio burned down to prevent its use by Native Americans (Cox and Ford 2001:11-13).

In 1721, Marques de Aguayo built Nuestra Señora de Loreto de la Bahía del Espíritu Santo on top of the site of LaSalle's Fort St. Louis. The presidio was intended to discourage any future French aggression and protect Mission Espíritu Santo as well as rescue shipwreck victims and deter coastal invaders (Faulk 1996:333-334). A map of the presidio showing a large palisade in the shape of an eight-pointed star found among the papers of the Aguayo expedition was considered by historians to be merely a plan for the presidio. Archaeological excavations at the site by the Texas Historical Commission in 1999-2001 found the setting trench for this elaborate fortification and discovered that not only was the map correct, even the scale was almost exactly right (Bruseth, J., personal communication 2002).

Within five years after the initial founding, however, the presidio was moved to its second location due to conflict with the Karankawa. The second site of La Bahía was along the Guadalupe River near presentday Victoria. In 1749, the presidio and mission were moved once again to the final site along the San Antonio River near present-day Goliad. Even at its newest location, the role of the presidio La Bahía was to protect Mission Espíritu Santo, but, in 1754, it was also charged with protecting Mission Rosario as well. The stone structures of the presidio were built during the 1790s. La Bahía, at its final location was able to withstand attacks from the Apaches and Comanches, as well as to prevent Dutch, English and French intrusions (Roell 1996:1067-1069) even before the stone buildings were finished. After Mexico gained its independence, Presidio La Bahía acted to protect and supervise many of the colonies that came to the area. During the fight for Texas independence, Goliad experienced much of the hostile action between the Mexicans and Texans, most notably the Goliad Massacre that occurred in 1836. Though Texas gained its independence, the presidio compound still did not fair well, with additional repeated attacks in 1842. Restoration efforts during the early and mid-1900s revealed several occupation levels at the presidio producing a myriad of artifacts relating to each period in the presidio's history (Roell 1996:1067-1069).

Presidio San Francisco Xavier de Gigedo was founded in 1750 to serve the three San Xavier missions, namely, missions San Francisco Xavier de Horcasitas, San Ildefonso, and Candelaria. The presidio was 
situated on the south bank of the San Gabriel River, west of the three missions. The presidio remained at this location until 1855 when, soon after the double murders of Ceballos and Fr. Ganzábal, it was moved to the San Marcos River with Mission San Francisco Xavier and Mission Candelaria. The presidio persisted for an additional two years at the new site until the soldiers were transferred to San Sabá (Habig 1990:184).

Presidio San Agustín de Ahumada, established in 1756, was originally located on the east bank of the Trinity River, approximately five miles north of Trinity Bay. Mission La Luz de Orcoquiza was founded three months later east of the presidio. San Agustín was destroyed by a hurricane in 1766, but was rebuilt on the east bank of the river within one mile of the original location. The presidial soldiers were relocated to San Antonio in 1770 (Habig 1990:184-185). By 1772, the missionaries from Mission La Luz abandoned the site. Repeated attempts were made by the French to settle in the area sometimes referred to as "Atascosita" over the years, until one succeeded in 1810 (Habig 1990).

The Presidio of San Luis de las Amarillas, commonly known as San Sabá, was situated in 1757 near Mission San Sabá on the north bank of the San Sabá River. The presidio was to protect the mission for the resident Apaches and to buffer San Antonio from the advancing Comanches. The presidio remained at its original location after the fall of the mission in 1758. More permanent stone structures were erected at the presidio in 1760, but this did not keep the presidial soldiers and their families from moving to San Lorenzo in 1768. While a few remained behind with some missionaries, by 1771 the remaining soldiers were recalled, transferring the garrison to San Fernando de Austria in what is now Mexico (Faulk 1996:1067-1069; Habig 1990:185-186).

Presidio San Elizario was established in 1780 along the Rio Grande near present day El Paso. The presidio was to serve the missions of San Lorenzo, Ysleta, Socorro, and Senecú, and to provide a colony of "pacified Apaches" (Timmons 1996:838-839). The chapel at the presidio served the spiritual needs of the surrounding town named San Elizario. In 1807, Zebulon Pike was imprisoned at Presidio San Elizario after crossing into Spanish territory and causing concern over possible American invasion. Until the presidio was recalled in 1814, a part of its function was to hold American traders, who were encouraged to enter Spanish territories after reading Pike's review on the commercial properties of New Mexico (Timmons 1996:838-839). The presidio's church was washed away in the big flood of 1829 . 


\section{CHAPTER 2: CERAMIC MANUFACTURING IN MEXICO AND SUPPLYING THE Missions AND PRESIDIOS OF TEXAS}

Soon after Spain's conquest of the New World, colonization of the Caribbean and Central and South America was underway. Spain established several colonial settlements in Florida and in the Caribbean that required manufactured Spanish goods. Central America became a significant destination for settlement as the precious mineral wealth of the regions became a major export. Spain initially supplied her colonies in the New World with needed goods such as food, clothing, tools, and other household items. The city of Seville held the monopoly on the exportation of Spanish and other European wares to the New World well into the colonial period (Lister and Lister 1987:201). As the populations of many of the settlements began to increase, the river ports at Seville could not keep up with the demands from the New World. To cope with the increased demand, some of the trade restrictions were loosened, though Seville still controlled the activity. When shipments of European wares did not reach New World ports to fill their needs, the settlers turned to indigenous potters to supply them with essentials for cooking and storage (Lister and Lister 1987:216). In a few instances Spanish households adopted native vessel forms to aid in some food preparation activities. The Spanish readily adopted the flat ceramic griddle used to cook tortillas (comales) and the heavy bowl with a ridged bottom used for grinding peppers, garlic, and other food ingredients (molcajetes) (Lister and Lister 1975:28). Overall, however, the Spanish settlers generally preferred to use glazed table wares, rather than the unglazed earthenwares produced by indigenous potters. They required chamber pots, oil lamps, candle holders and roof tiles for their houses (Lister and Lister 1975:29). In the kitchen, women needed the heavy, flat-bottomed cooking dishes known as cazuelas to prepare certain dishes. Though indigenous potters were highly skilled, they did not produce these vessel forms, and shipments from Spain were either too costly, or not reliable enough to adequately supply the population (Lister and Lister 1987:216-217). The answer to the problem was to teach the Native American population to produce Spanish-style ceramics.

\section{MAnUfacturing Sites}

The sixteenth century marked the beginning of ceramic manufacturing in Mexico. The earliest records of potters producing Spanish wares in Mexico date to 1537 and 1538 (Lister and Lister 1987:218). By the end of the sixteenth century, the bulk of the goods needed by the settlers were produced in the major population centers of the Spanish territory (Deagan 1987:23). Figure 2-1 is a map showing the locations of the major ceramics manufacturing centers in Mexico. 


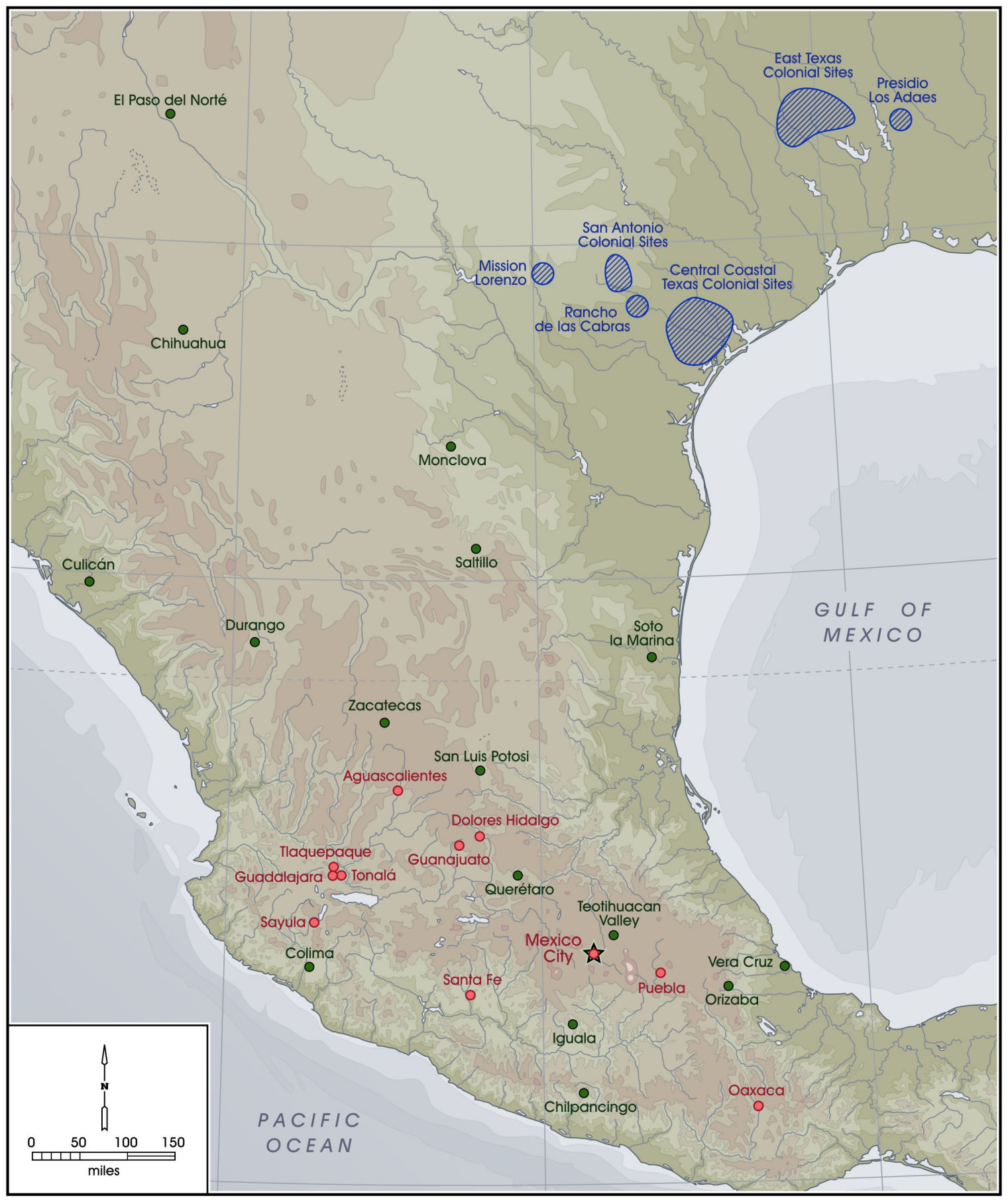

Figure 2-1. Map showing locations of Mexican ceramics manufacturing in the Colonial period.

Mexico City became home to several ceramic manufacturers soon after conquest. To supply the demand for white table wares, glazed cooking vessels and other furniture vessels (i.e., chamber pots and oil lamps), the Spanish potters employed the indigenous individuals to imitate the Spanish-style majolicas. Later, these pottery complexes developed their own styles: a mixture of Native American, Chinese, Spanish (with its Moorish components), and Italian influences (Lister and Lister 1974:24). 
Near the middle of the sixteenth century, majolica manufacturing was initiated in Puebla (Figure 2-1), which soon became the largest production center producing the tin-glazed wares (Lister and Lister 1974:26). Puebla not only had the natural resources, but also a great supply of native labor to use in the procurement of materials and production of the ceramics (Lister and Lister 1987:231). Clay resources were readily available, as were minerals such as tequesquite, (soda ash, a mineral salt, a combination of chloride and sodium carbonate), needed for producing glazes (Lister and Lister 1974:26).

The Puebla ceramic industry developed as a mixture of styles produced by Native American potters under Spanish supervision (Lister and Lister 1975:33, 1987:221). Andalusian styles were, of course, copied, although Mexican wares never exhibited the blatantly Moorish designs that were seen in earlier Caribbean sites (Lister and Lister 1975:33). Italian influence was a major factor in European majolica designs and this is also reflected in the designs seen in Mexico (Lister and Lister 1974:24-25).

Chinese porcelains began arriving in Mexico in the last quarter of the sixteenth century and began influencing the quality of the wares produced in Puebla and the other Mexican pottery centers (Lister and Lister 1987:252), and the shapes of some vessels (such as handleless cups) (Lister and Lister 1975:39). Most importantly, however, the Chinese influence resulted in the adoption of a blue-on-white color scheme, often with copies of oriental design elements (Lister and Lister 1975:39).

As the Mexican ceramic industry developed, two grades of wares, a common ware and a more refined "fino" grade were manufactured (Lister and Lister 1987:234-237). The ceramics found on Colonial sites in Texas would have been almost exclusively common grade. Puebla continued to be the main center for the production of ceramics during the remainder of the colonial period. To this day, the ceramic industry still plays a big part in the economy of Puebla.

As the ceramic industry progressed in Mexico City and Puebla, other towns began production of comparable wares. Communities in Dolores, Tlaquepaque, Tonalá, Hildago, Guanajuato, Santa Fe, Aguascalientes, and Oaxaca (Figure 2-1), produced various styles of majolica, lead-glazed, and burnished wares.

Unfortunately, many of the ceramic types that are identified in Texas cannot be attributed to one specific location. This is particularly true of the more common unglazed and lead-glazed wares, simple utilitarian wares which were probably produced in many of the manufacturing sites listed above. On occasion, the decoration type is indicative of a certain town's style. 


\section{Supplying The Missions In TeXas}

Each missionary was equipped with supplies upon the initial arrival at a new location. The supplies included the necessary objects for performing a mass, farming (including seeds and tools), household items needed for cooking and serving food in a European style, and goods to entice the indigenous populations (beads, necklaces, fabric, etc.) into the mission. The soldiers also brought with them enough supplies to establish a functioning presidio. Once established, both missions and presidios needed to be re-supplied on a regular basis (Leutenegger 1976:31).

The system in which the missions and the presidios received their supplies differed greatly from each other. Missions, in theory at lest, were to be self-sufficient by producing all that was needed for daily life. In reality however, some items could not be produced locally (Leutenegger and Perry 1976:31) and they had to be brought from Mexico. Procuring supplies for the missions was usually the job of each mission's Procurator of Supplies. The Procurator would travel to the college headquarters with the list of supplies from the mission. From the college, the Procurator would go to Mexico City, usually in April, to purchase the requested supplies. He would then return to the college in September with the loaded pack train, and depart to Texas in mid-October. The supplies would be unloaded at the mission, where the Procurator would receive the list of requested supplies for the next year. In the beginning of March, the Procurator would begin the cycle again by launching his journey to the college headquarters.

Since no roads suitable for wagon traffic had yet been built (Ivey and Fox 1999:44), mule trains were the principal means by which goods were transported from Mexico. The mules could carry a heavy load and were able to navigate the rough terrain and river crossings. A mule train would travel between twelve and fourteen miles per day. When the supply train arrived at the mission, the missionary was responsible for distributing the supplies, according to a predetermined plan (Leutenegger 1976:27-30). In his annual report, the missionary was expected to list those items needed for the next shipment from Mexico (Leutenegger 1976:31).

Each mission had slightly different requests each year, though there were certain items that were commonly asked for. Items requested for the missionaries themselves included fine chocolate, piloncillo (unrefined sugar pressed into a cone shape), wine, snuff, tobacco, sweets, cumin, salt, pepper, and rice. The missionaries would then request goods for the natives that included ordinary chocolate, beads, necklaces, earrings, rosaries, fabric, ribbon, tobacco, piloncillo, sombreros, and brushes. The train also brought in comales, copper pots used for cooking and water storage, and other items that were in need of replacement. Ceramics manufactured in Mexico routinely were requested each year (Ivey and Fox 
1999:44). The goods were distributed upon arrival, except for the chocolate and tobacco. Every woman received a piloncillo, ribbon, beads, fabric, a petticoat, needles, thread, and a brush. Every man received a piloncillo, a pair of shoes, a hat, and a knife, with their fabric allotment given to the tailors to make new clothes for them. The tobacco was distributed after Sunday's mass, and everyone received a chocolate bar on Easter (Luetenegger 1976:31).

As part of the enculturation process the missionaries made a point of separating themselves from the neophytes in many ways. Archaeological and archival evidence suggests, for instance, that the fathers had a substantially different diet from the Native Americans in the missions (Meissner 2000:60). This differentiation extended even to chocolate, which was sent to the missions in two varieties, common chocolate for the neophytes and "fine" chocolate for the missionaries (Habig 1978:17) The few Native Americans who had been given positions of authority also received prestige items. For instance, although both cotton and wool cloth was woven at the missions, the neophytes and missionaries alike clearly recognized that the cloth "from Puebla" that they ordered with their other supplies was greatly preferred, and the missionaries used the distribution of this cloth as a prize for good behavior and to distinguish those Native Americans who had been put in positions of authority (Leutenegger 1976:29). Glazed pottery, especially majolicas, may also have occasionally served as prestige items for such people.

The presidios also relied on the mule trains to get their supplies, though the frequency of the trips and the type of goods were different from that of the missions. The soldier was expected to buy his food and equipment, in addition to supporting his household if he was married. The presidial soldiers' salary was sent from one of two towns in Mexico and had to be brought to the presidios in Texas, but was seldom received solely as cash (Moorehead 1975:202). Several times a year, the captain sent out a detachment of soldiers and the quartermaster to Saltillo or San Luis Potosi to receive the payroll, purchase goods for the soldiers and return to the presidio. On many occasions, the soldier's pay would be half money and half goods. Other times, the soldiers would be paid entirely with goods (Moorehead 1975:202). The paymaster, the individual who accepted the soldiers' salaries, would charge a fee for the services of purchasing and transporting the goods and salaries (Moorehead 1975:203). In addition, the presidial captain would inflate the cost of the supplies to turn a profit for himself. When the soldiers received goods as part or all of their salary, they would be given uniform, weapons, gunpowder, saddlery, and shoes. Items that soldiers ordered included soap, cigars, blankets, sackcloth, ribbons, and fabric, although they frequently paid ten times the original price for the item. This often left the common soldier without enough money to pay for required items, much less any luxuries (Moorehead 1975:207). Over the decades of Spanish occupation, the payroll system for the soldiers was altered several times to attempt to deal with the inflated prices and low salaries, with limited success (Moorehead 1975:206-219). Even 
though many of the items were overpriced, the soldiers still had to provide for their households. This meant that even the supply trains headed to the presidios brought with them from Mexico a multitude of utilitarian items such as kitchen utensils, cook wares, and service wares such as plates, cups, and bowls (Habig 1990).

The means of supplying the villas associated with the presidios is quite unknown. When supply trains would arrive at the presidios, it is possible that the presidial captain would sell goods to the families living in the surrounding villas. However, as in the case of the Canary Islanders, "merchants" were living in the villas soon after their establishments. The merchants were supplying the community with necessary goods some of which may have been produced locally with the rest obtained from Mexico. Records at the Bexar County Archives do indicate that smuggling was one of the methods used to bring goods from the Gulf Coast to the interior of Texas. More research is necessary to develop a better understanding of the supply system of the settlements throughout Texas.

Archaeological investigations at Spanish Colonial presidios and the missions in Texas have revealed differences in the amounts and types of ceramic wares brought to and/or used at these sites. For instance, glazed wares tend to be more common at presidio sites compared to missions (Cohen-Williams 1992:123). The dominance of glazed wares within presidio collections is probably due to the fact that Spanish presidio soldiers preferred glazed (Lister and Lister 1974:24) over unglazed wares made by Native residents of the missions. In addition, while the missionaries also preferred glazed wares, Nativemade wares were numerically more common in the missions because they represented the wares used by the neophytes that outnumbered the Spanish residents. The everyday utilitarian wares were produced locally using manufacture and firing techniques that most likely differed from those of the Spanish potters. Some variation on the locally made ware is evident, with stylistic attributes to mimic the European vessels, but the majority of the Native American ceramics found at the missions were not altered from prehistoric styles. While it has been assumed that most of the Spanish-made majolicas were made in manufacture centers in Mexico, recent Instrumental Neutron Activation Analysis has revealed that some glazed wares may actually be made in Texas (Carlson 2007). Whether the potters are Spanish or Native craftsmen that learned the Spanish manufacture and decorative techniques is not know at this time, but it does raise questions about our assumptions of the manufacture localities of ceramic wares that are based simply on decorative techniques. 


\section{CHAPTER 3: DEFINING VARIATION IN MANUfaCtURE, SURFACE TREATMENTS, AND VESSEl FORMS IN SPANISH COLONIAL CERAMICS}

The ceramics recovered from Spanish Colonial sites in Texas have been divided into categories that are determined by their manufacturing technique, paste, glaze, and decoration. This chapter provides a brief discussion of how ceramics are characterized in each of these categories. A glossary of ceramic terms can be found in Appendix A.

The ceramics made by Native Americans in much of Texas before the arrival of Europeans were unglazed bone and/or sand tempered wares. They were sometimes carefully smoothed or burnished and sometimes decorated with incising or painted with asphaltum. The ceramic tradition of the Native peoples, especially in Central and South Texas continued with little change throughout the mission period and these ceramics are often the most common at mission sites (Hester 1989:224). Most Native American ceramics manufactured in Texas have no glaze applied to the vessel walls. In most instances, the vessel walls are smoothed, sometimes close to the state of burnishing. The Spanish settlers could never grow accustomed to the lack of glazes on ceramic table wares (Lister and Lister 1987).

Mexico City became the first center in New Spain to develop a European-inspired ceramic industry. It began with potters first having to locate an adequate supply of clay that would fire to a lighter color than the typical Native American wares (see Lister and Lister 1987). The right kind of clay was available only outside of the Valley of Mexico, and had to be brought into Mexico City. Raw materials for the production of the glazes applied to the ceramic vessels also were needed. Shortly after the fall of Tenochtitlán, mining for tin began prompted by the need to cast new cannons. The tin also was needed by potters to create the opaque, white glaze that is characteristic of majolica. Sodium was another mineral essential to producing the smooth glaze typical of European wares. Ample tequesquite, the rocky material found in salt flats, could be gathered from saline lakebeds throughout the Valley of Mexico. For decoration, cobalt was needed to create the blue accents typical of colonial majolicas (Lister and Lister 1987:223). Supplies of cobalt would have been imported from Spain (Lister and Lister 1987: 223).

The ceramics recovered from the Spanish Colonial sites in Texas have been divided into categories based on their manufacturing technique, glaze, and decoration. These categories will be briefly discussed next. 


\section{MANUFACTURING TECHNIQUES}

There are two basic methods of creating hollow wares (ceramics such as cups, bowl, plates, etc. as opposed to tiles or bricks) with walls that are more or less uniform in thickness so that the clay does not crack during the firing process. The first method, used both by European-influenced and Native American potters, was hand-building. There are several ways to hand-build ceramics (Rice 1987:125129):

- Coiling. The vessel is built up by coiling thin ropes of clay on each other until the right height has been reached, then smoothing the clay coils into thin, even walls that will not break during firing.

- Pinching and/or Drawing. A lump of clay is shaped by pinching and pulling it into the desired shape.

- Slab building. Clay is rolled into slabs, which are then joined to create the body of the vessel.

- Molding. Clay is rolled into a thin layer and then shaped by pushing it onto a mold.

The second method is wheel-throwing. A lump of clay is placed on a "wheel", a round, flat surface that is turned slowing. The clay is then smoothed into an even shape with the hands, while the turning wheel insures that the vessel walls maintain an even thickness. Examples of both methods are found in Spanish ceramics in Texas.

\section{Paste TyPeS}

Paste characteristics, the clay fabric of the vessel (see glossary in Appendix A), play an important part in the classification of ceramics. In the case of the Spanish ceramics in Texas, there are only a few different classifications to consider. All mission-period Spanish ceramics are unrefined earthenwares. Some are coarse, fired at low temperatures, with large percentages of sand in the clay and with coarse-grained tempers. Some are fine, fired at higher temperatures, with smaller percentages of large-grained sand and with finer-grained temper. The color of the paste and type of inclusions can also be used to differentiate sub-groups of ceramics. 


\title{
SURFACE TREATMENTS
}

\author{
UNGLAZED WARES
}

Unglazed ceramics are usually considered "utilitarian" wares, commonly known as cooking utensils, washing utensils, and storage containers (Deagan 1987:30-43). One of the most common unglazed vessel types is the olla or water container. The unglazed body of the vessel allowed a slow seeping of water to the surface of the pot, where it evaporated, cooling the pot surface, and the water contained in the vessel. Shipping containers, usually called "olive jars" are another common unglazed vessel type. Some olive jars have a lead glaze on the interior to prevent seepage (Deagan 1987:30-43). Other unglazed vessels included various cooking and baking dishes and large bowls or basins.

\section{Burnishing}

Usually smoothed by hand or with a wooden tool, unglazed ceramics can also be burnished. Burnishing creates a smooth, highly polished surface, without the application of a glaze. The burnishing of the ceramic vessel takes place during the "leather-hard" state, when the clay has dried and before firing. A hard smooth object is rubbed on the surface of the paste, pushing all the courser grains below the surface, while compacting and aligning the fine-grained surface particles (Rice 1987:473). Burnished ceramics can be decorated by painting, but some burnished ceramics in Texas have been decorated by creating highly burnished designs on a less burnished "matte" background.

\section{Slip Decorated}

Some unglazed ceramics are decorated with a thin layer of slip, which is a thin emulsion of clay, usually of a color different than the vessel body that is applied to the vessel before firing. The slip can be applied to the entire body or painted on in a pattern. The slip is usually rubbed into the fabric of the pot to some extent, but is also sometimes burnished before firing.

\section{GLAZED WARES}

A glaze is a coating of glass melted onto the body of the ceramic. Glazes are mixtures of many ingredients, including the silica that melts into glass and other ingredients to create different colors and make the glaze tougher (Rice 1987:151). Glazes can be used to change the color of the vessel, and to protect painted designs, but the primary advantage of glazing is that the glassy surface is water-proof. The two major glaze types in Colonial ceramics are lead glaze and tin glaze. Figure 3-1 shows examples of cross-sections of tin and lead-glazed specimens. The cream color of the tin glazed wares is typical while the lead-glazed wares are transparent and exhibit the color of the clay fabric, unless painted. 


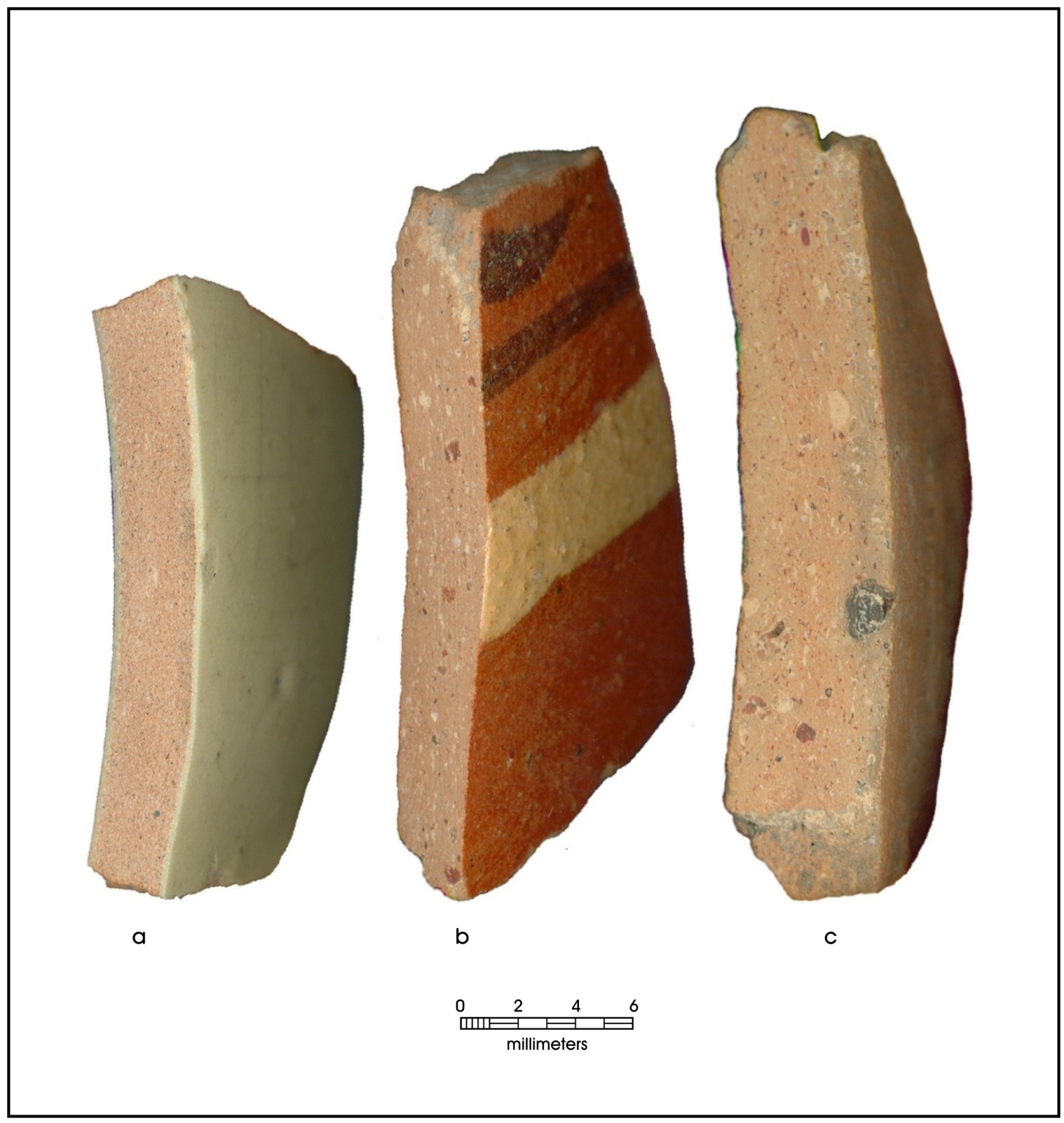

Figure 3-1. Examples of tin (a) and lead-glazed (b-c) specimens. Note that the inner face of 3-1 c is lead glazed and the outer face is not glazed.

\section{Lead Glazes}

Lead glaze is a thin glaze that can be clear, revealing the color of the clay body and any painted decoration, or colored, including green, yellow, orange, or brown (see Chapter 4). In some cases, the glaze is so thin that it initially appears that the vessel has no glaze. A quick examination of the sherd's surface will reveal a reflection of light if glaze is present. Lead glazes are often applied to only parts of a vessel, usually the inside. Lead-glazed vessels are categorized by the paste, then by the color of the glaze and decoration. 


\section{Tin Glazes}

Tin-glazing, also known as majolica and faience, is produced by adding tin to the lead glaze (Lister and Lister 1974:17). The tin causes the surface to become opaque in shades of white, cream, blue, yellow, and green depending on any further additives. The opaque surface is sometimes left blank, but more often is decorated with painted designs executed in various colors. Tin-glazed wares are classified in terms of decoration.

The dates attributed to various decorative patterns seen in Mexican majolicas are to some extent based on the dates attributed to places where they have been found. In addition, there is what can be called the "bargain" factor. As Ivey and Fox (1999:44) note:

It can be assumed that the relatively low level of financial support given to the missions, the vows of poverty taken by the Franciscans, and the cumbersome mechanics of the supply system itself all tended to influence ceramics purchasing in the direction of "bargains." ...In fact it is suggested that the ceramic types and frequencies found in Texas were caused by the purchase of whatever varieties of majolica were beginning to form backlogs in supplier stocks as their popularity dropped off among the general consumer population of Mexico. In other words, the dating and frequency of ceramics in Texas may be the result, not of actual production curves and dates of first and last manufacture of a type, but of its peaking and declining popularity. ...much of what is found on the Texas frontier may not have been the best, or the worst, ceramics but merely the best bargains available at the time they were purchased.

Lister and Lister (1976a) also discuss this issue. Additionally, the "heirloom" factor comes into play. Some ceramics may not have been broken until long after the particular type was manufactured. Obviously, this makes it necessary to add "about" to all temporal estimates.

\section{VESSEL FORMS}

Ceramic sherds recovered from archaeological excavations at Spanish Colonial sites in Texas are usually too small to allow an understanding of the vessel form. Occasionally, however, sherds are large enough to reveal that there was great variation in the types of vessels utilized by the Spanish and Native American inhabitants (for example, see Cargill et al. 2004:63; Meissner 1996:66; Schuetz 1969:50-58). Occasionally ceramic assemblages derived from shipwrecks have provided invaluable information about vessel forms given the completeness of the vessels recovered (see Marken 1994). The vessel forms utilized at the missions and presidios can be divided into the following categories: storage, cooking, table service and household items. Some of these forms have been found in Spanish sites in Texas. 


\section{STORAGE VESSELS}

Fragments of storage containers are commonly found at Spanish colonial sites. The forms of the vessels represent both the Spanish settlement on the Texas frontier and the indigenous people coping with the need for adequate water storage. Vessel forms such as the jarra, cántaro, tinaja, orza, and botija (Figure 3-2) were used to transport items like mustard, olives, oil, pitch, and cacao between Spain and the colonies (Lister and Lister 1987). The vessels were reused for other functions. One category of storage jar, used to transport liquids such as olive oil and wine, was the olive jar (Avery 1997:91). Native-made, unglazed ollas were used as water storage vessels due to their ability to keep water cool.

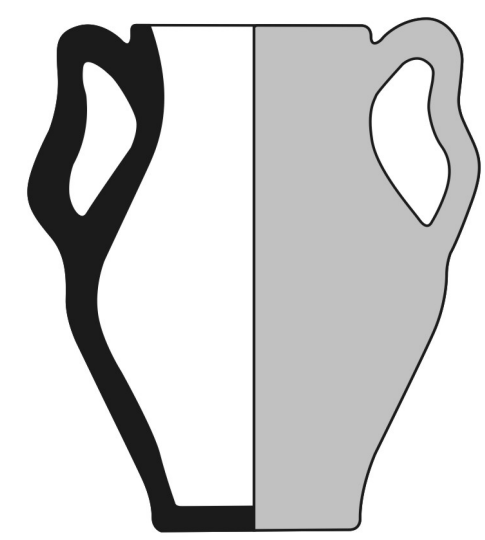

a

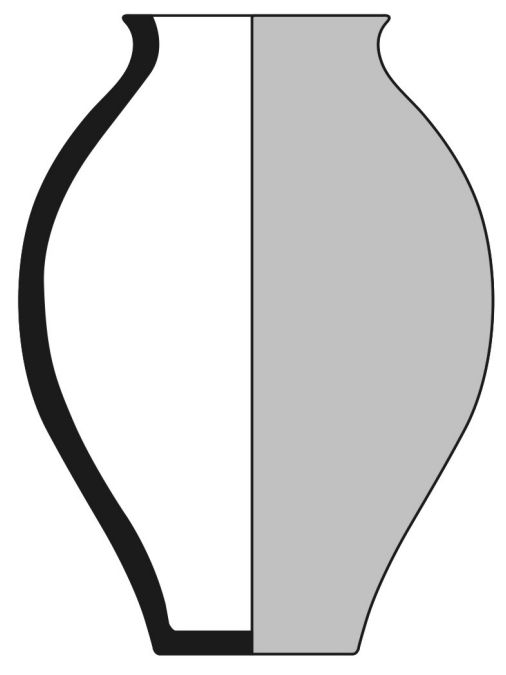

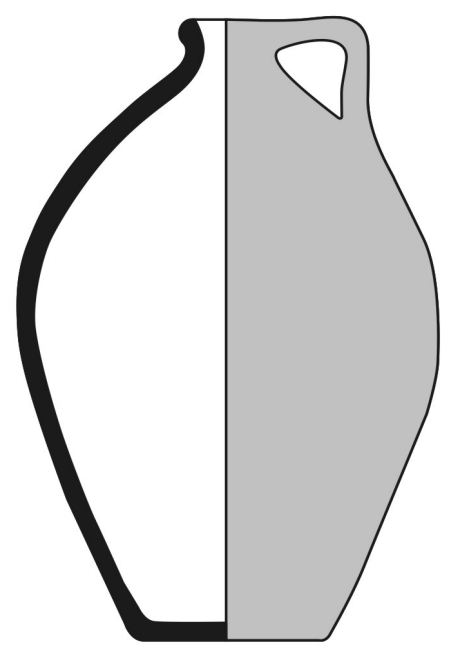

b

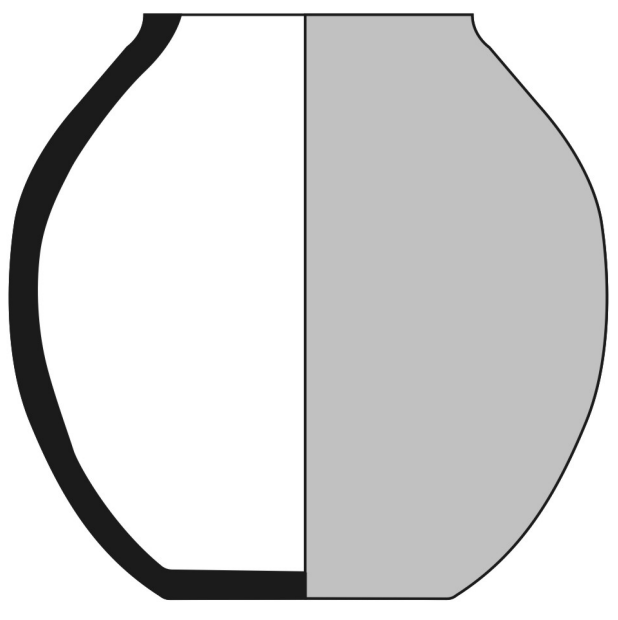

d

Figure 3-2. Examples of large storage containers: a) jarro; b) cántaro; c) tinaja; d) orza. 


\section{COOKING VESSELS}

Cooking vessels range from small molcajetes to large cooking pots. The molcajete, a rounded bowl on a tripod of legs, with incised grooves on the interior, was typically an unglazed or lead-glazed vessel that was used for grinding chilies and garlic to add to food. Molcajete fragments have been recovered from both mission and presidio sites.

The cazuela, a type of stewpot, would have been more likely to be found in the kitchens of the families associated with the presidios and other settlements. It might come in many sizes. Other forms of cooking vessel are the cacerola and the bean pot. The comal, an unglazed ceramic griddle, was used to prepare tortillas for the household. Though records from the Spanish missions show that iron comales were imported by the missionaries (Leutenegger 1976:27), fragments of clay comales have been recovered from several mission and presidio sites.

Large bowls of various sizes were used for mixing and other purposes. Chocolateras, or chocolate pots, were used to make the Mexican hot chocolate drink.

\section{TABLE SERVICE VESSELS}

Service vessels consist of all those forms that would be utilized as table ware. There is a continuum in vessel forms between what in modern terms are called plates (platos, soperos), and bowls (Figure 3-3a-b). Cups came in a number of forms (tazas, pocillos, escudillas) many of which have been found with and without handles (Figure 3-3c-e). Simple pitchers, such as the one shown in Figure 3-3f, have also been found. Bowls and jars were used as communal service vessels, storing the entrée or condiment before its distribution at mealtime (Figure 3-3g-h).

For the most part, the native inhabitants of the missions continued using vessels similar to those used before the missions were established. Vessels for the individual service of food were not common in the most native ceramic traditions (Lister and Lister 1987). Instead, there had been a more communal way of dining before the arrival of the Spanish. The extent of the influence of Spanish occupation on the indigenous people can be seen in the ceramic assemblages recovered from many of the mission sites in Texas. Although most of the unglazed, native-made ceramic sherds collected from Spanish Colonial sites appear to be fragments of large vessels, some sherds indicate smaller bowls. In addition, forms that resemble the Spanish version of the bowl and cup were recovered. These exhibited foot-rings and lipped rims, although they had unglazed bodies (Ulrich 2004). 


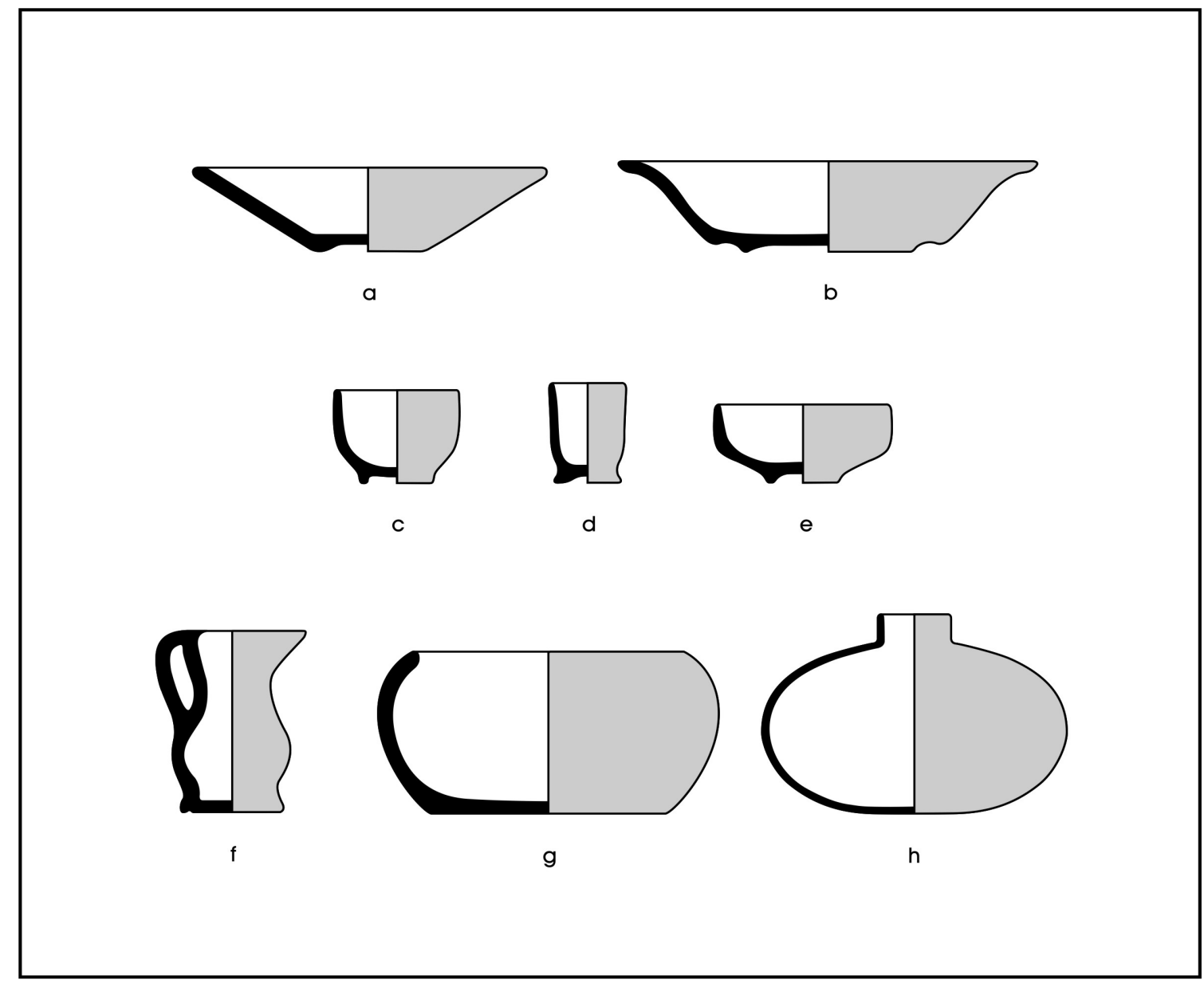

Figure 3-3. Examples of table service vessels: a) plato; b) sopero; c) taza; d) pocillo; e) escudilla; f) pitcher; g) bowl; h) jar.

\section{OTHER CERAMIC ITEMS}

Other ceramic items that were recovered from Spanish colonial sites include household objects such as chamber pots. Several examples of unglazed ceramic candlestick holders were recovered from excavations conducted at Mission San Juan Capistrano in San Antonio, Texas (Schuetz 1969: Plate 34). These holders consisted of a small, saucer-like base, with an attached hollowed stem to hold the candle. Fragments of piloncillo molds also have been found. These are cone shaped molds made of soft-paste ceramics, usually unglazed, designed to mold the cones of unprocessed sugar that were so popular with both Native Americans and Hispanic inhabitants. Piloncillo is still being used today, though the molds are now usually made of wood.

French cosmetic jars are sometimes recovered from the presidio and mission sites (Figure 3-4), especially in East Texas. These jars are soft-paste, tin-glazed earthenwares referred to as faience. Pipe bowls have been recovered from both presidio and mission sites, made of either local or imported materials. 


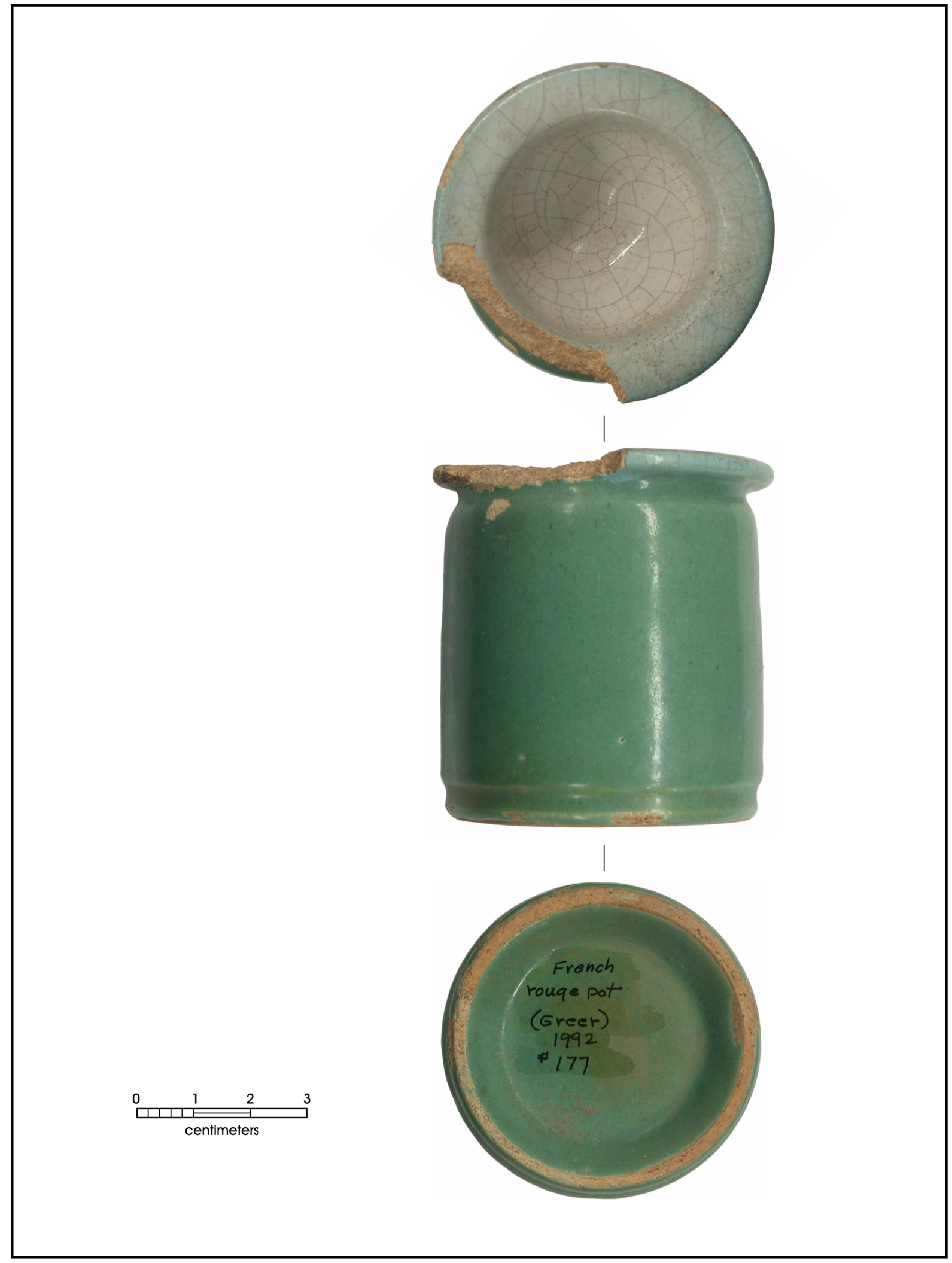

Figure 3-4. French cosmetic jar with faience tin-glaze. From the Greer Collection. 


\section{CHAPTER 4: CERAMics From SPANiSh COlONiAl Sites IN TEXAS}

This is the first publication to summarize Spanish Colonial ceramics recovered from archaeological sites in the state of Texas. It considers unglazed as well as lead- and tin-glazed wares. While it groups ceramics based on design elements, a number of the groupings, particularly among the unglazed and leadglazed wares, are poorly known in the state. Therefore, the majority of these unglazed and lead-glazed wares are categorized based on formal descriptions. They have not been sufficiently studied and their relationships to named types not well enough understood to define these wares as formal types (i.e., the unglazed Red Burnished wares or the lead-glazed Yellow Glaze and Green Glaze I wares). In other instances, where the unglazed or lead-glazed wares are better known and have been more fully characterized and securely dated (i.e., unglazed Valero Red Painted and Tonalá Burnished; lead-glazed Galera and Tonalá wares) we use the type names that have been in use for some time in the Texas literature. In discussing the tin-glazed or majolica wares, we have been able to rely on the extensive work with these wares in Florida and California. When we discuss ceramics that fit established types we use the already known type designations. Also, we identify the relationships of the types illustrated in this volume to the classification systems used in Florida and California. However, we do not use the proposed and/or existing variety designations within majolica types disseminated in the literature. Ceramic research has not progressed sufficiently in Texas Spanish Colonial sites for the confident identification of types and varieties within most lead-glazed wares. The majority of the majolica sherds recovered from Texas sites are so small that it is not possible to determine the full designs represented. This hinders a detailed consideration of the relationships between the different design groups noted in the archaeological collections and limits confidence in the designation of ceramic varieties. In two instances (i.e., Puebla Blue on White and Aranama Polychrome), we use the term "tradition" to refer to the broader grouping of related types already established in the literature. This taxonomic scheme is in its infancy. We hope that this work will encourage others to further develop the preliminary designations made here, and look forward to a period when a systematic, well developed scheme is in place for Spanish Colonial ceramics found on Texas sites.

In the following sections, we group the Spanish Colonial ceramics based on broad unglazed and glazed groupings. The glazed group is further subdivided into lead-glazed and tin-glazed subgroups. The leadglazed wares are divided into sandy paste and fine paste sub-groups and the ceramics within the tinglazed subgroup are organized into broader clusters based on broad temporal periods (i.e., late $17^{\text {th }}$ century, $18^{\text {th }}$ century, etc.). 
The discussion of each form includes a brief history of its definition and/or naming and, when appropriate, the relationship of the ware to types/varieties documented in Florida or California. We have not defined formal types in many cases because of uncertainties regarding relationship to extant types and the relatively small sample sizes studied. This brief history is followed by a general description of the form that includes the decoration, method of manufacture, paste description, sherd thickness, and any other information that will help in identification. There follows a paragraph on the shape and size of vessels, where known, an estimate of the dates of manufacture, and a statement on what is presently known about the place of manufacture. Illustrations on the facing page show minor differences within a type as well as details of color and shape of vessels. In many cases, sufficiently large sherd fragments do not exist to allow us to reconstructs entire design motifs represented on the ceramics. Captions include the site number at which each illustrated sherd was collected. Site names and additional references on these specific sties are in Appendix B.

\section{Chronology}

One of our principal aims in this work was to provide a chronological ordering of Spanish Colonial ceramics found on sites in Texas. We hope that this preliminary chronological scheme will aid archaeologists in determining relative and/or approximate dates for the components they investigate. The dates, presented in Figure 4-1, are linked to the appearance of the types at colonial and historical sites throughout Texas, as well as records of manufacture and export from Mexico. Dates of manufacture were gathered from the many sources. These include Avery (1997), Barnes (1980), Barnes and May (1972), Brain (1979), Calhoun (1999), Caywood (1950), Cohen-Williams and Williams (2004), Deagan (1987) Gilmore (1973), Gerald (1968), Goggin (1968), Gregory (1980), Ivey (1983), Ivey and Fox (1981, 1999), Katz (1979), Lakeman (2001), Lister and Lister (1974, 1987), May (1975), Ricklis et al (2000), Seifert (1977), and Smith (1965). In many cases, the date ranges have been adjusted by the lead author based on several decades of working with Spanish Colonial material in Texas. For some wares, the tail-end of the period of manufacture coincides with the beginning of the surge in colonial occupation in Texas. Others

appear at the end of the colonial period in Texas, but when Mexico still provided the majority of wares that made their way into the territory. All dates are approximate and subject to revision. 


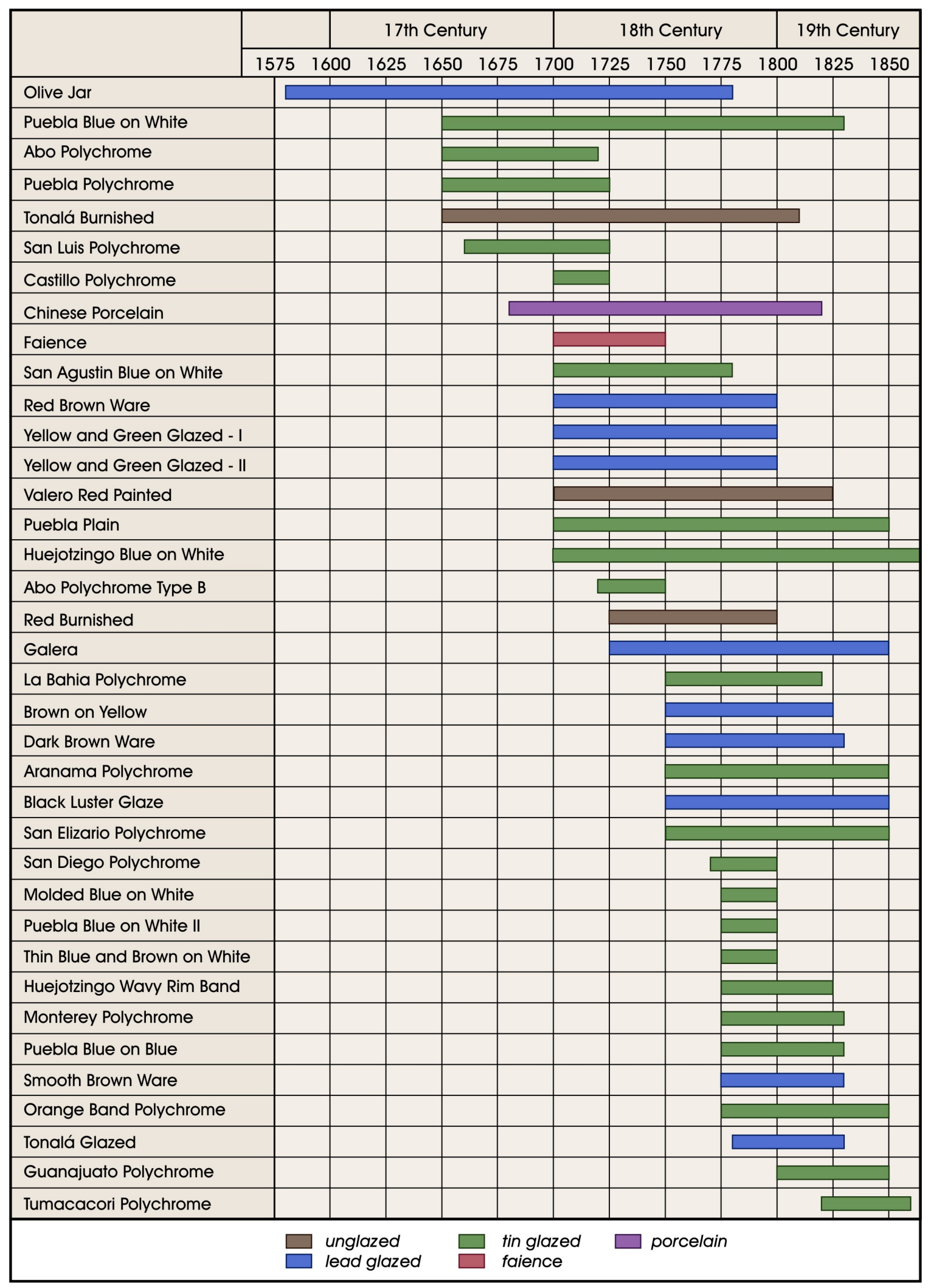

Figure 4-1. Chronology of ceramics from Spanish colonial sites in Texas. 


\title{
UNGLAZED WARES
}

\author{
VALERO RED PAINTED
}

This type was recognized and given a descriptive name-Red-on-Orange-during the first excavations at the Alamo (Greer 1967:19) and given a more formal name during later investigations in Alamo Plaza (Fox and Hester 1976:67). At that time, the term Valero began to be used by researchers at CAR and elsewhere. Valero ware has also been recovered from colonial sites all over South Texas as well. It is a type that appears to be restricted to Texas.

\section{General Description}

This type is wheel-made and has clearly visible manufacturing striations (Figure 4-2 b-c). The only decoration is bands of red-brown paint approximately one $\mathrm{cm}$ wide made from red ochre, usually horizontal (Figure 4-2 a-e) but occasionally vertical, although many sherds have no decoration. Sherds have reddish-tan paste and the vessels have been fired under controlled high oxygen conditions, resulting in their being the same color throughout. The average thickness of the sherds is $7 \mathrm{~mm}$.

\section{Vessel Forms}

So far, insufficient numbers of sherds have been recovered from a site to allow reconstruction of a complete vessel. The curve of the sherds indicates that the vessels were relatively large and bulbous, probably intended to be used as water jars. The absence of a glazed surface would have allowed natural cooling of the water inside the vessel through evaporation of water from the outer surface of the vessel. This appears to be the only vessel form used in this type of ware. Three fragments of a large vessel that appears to have been a water jug were found at the bottom of a (probably post-Colonial) ceramic kiln near Mission Espada in San Antonio (41BX4; Cargill et al. 2004:63).

\section{Estimated Dates}

This type seems to occur throughout the eighteenth century and may well continue into the nineteenth century (see Figure 4-1).

\section{Place of Manufacture}

The mission registries of Texas make no mention of the presence of wheels for manufacturing ceramics. Therefore production of the Valero wares was likely not local. The most probable place of manufacture is Mexico, though the exact location is unknown. 


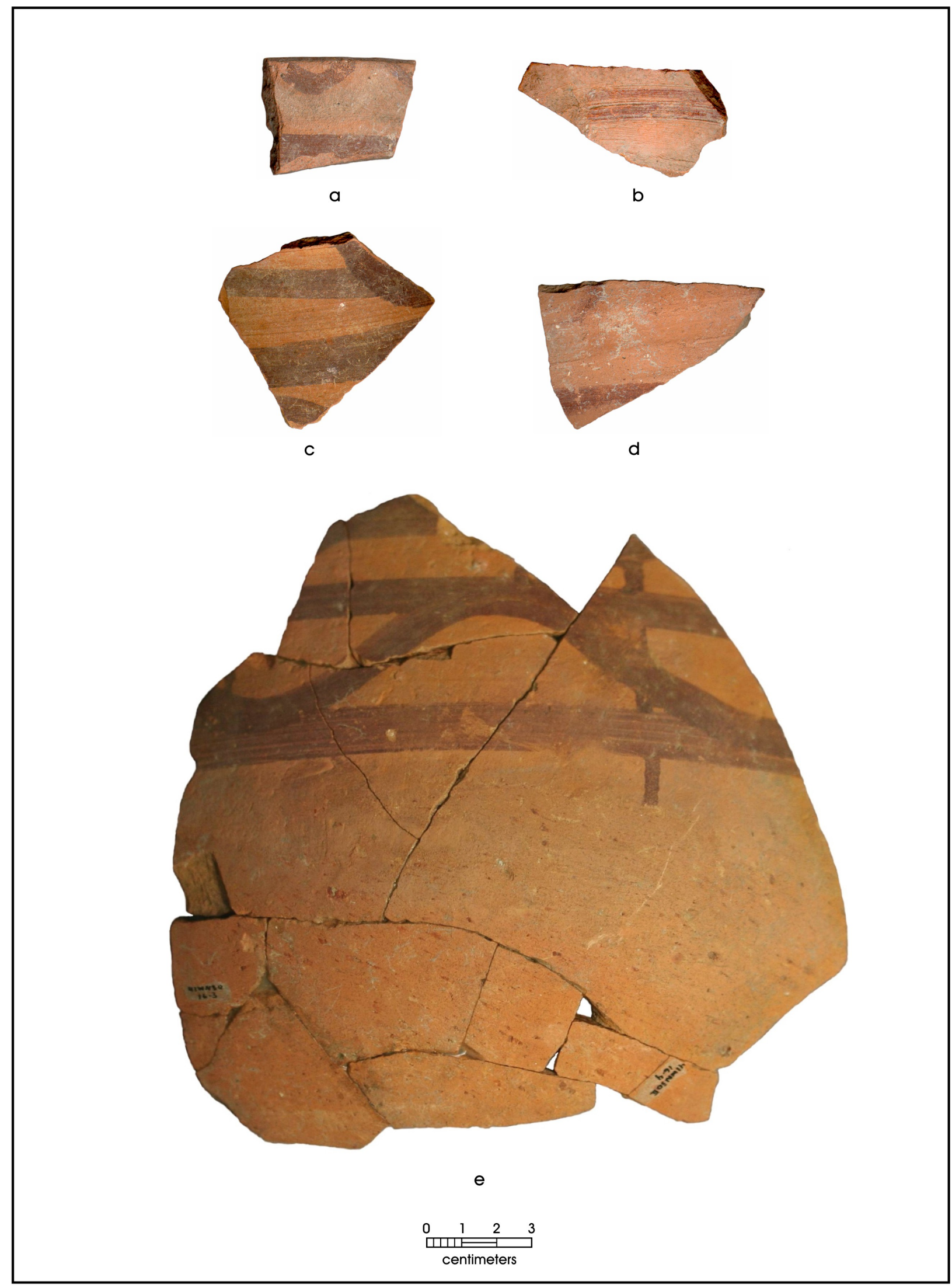

Figure 4-2. Valero Red Painted..4.1WN30: $a, c, d, e ; 41 B X 6: b$. 


\section{TONALÁ BURNISHED}

The Tonalá Burnished type is also referred to as Aztec IV (Smith 1965:90), Guadalajara Polychrome (Deagan 1987:44-46; Goggin 1968:226), and Tonalá Bruñida Ware (Charlton and Katz 1979:45). Deagan opted to use Guadalajara Polychrome to identify the ware due to possible confusion with a later, related lead-glazed variety. Here we add the surface treatment to the type name to eliminate confusion. Tonalá Burnished wares have been recovered from the San Antonio missions and surrounding colonial sites. The ware has been found at colonial sites throughout the southwestern United States, Florida, the Teotihuacán Valley of Mexico, and the Caribbean (Rishel and Stratton 2006: 118; Charlton and Katz 1979:45). This type was highly valued by the Spaniards and often shipped to Spain (Charlton and Katz

1979:52). Popularity of Tonalá Burnished waned with the introduction of European white earthenwares during the late $19^{\text {th }}$ and early $20^{\text {th }}$ Centuries (Charlton and Katz 1979:53).

\section{General Description}

This type of ceramic has a fine, gray to tan paste that has a sweet, earthy fragrance when damp (Figure 43). The common term for the clay from which the vessels were made was búcaro (Fairbanks 1973:170). Most vessels have thin walls (ca. 4 to $6 \mathrm{~mm}$ ) and break into small fragments. They are often painted with delicate, closely spaced red, black and occasionally yellow geometric and/or linear designs and bands, over a creamy white slip and then highly burnished (Figure 4-3 c-f). Some sherds are totally red or black on one surface (Figure 4-3 a-b), but the thickness and the paste indicate they are the same ware as that with colored designs. There is no evidence of wheel throwing, and potters traditionally have used convex, mushroom-shaped molds to make these vessels (Charlton and Katz 1979:47).

\section{Vessel Forms}

Deagan (1987:46) reports that cargoes of eighteenth-century shipwrecks included bowls, some with lids, and novelty figurines of this ware. Goggin (1968:227) mentioned small cups and plates as well. Charlton and Katz (1979:46) excavated sherds of jars with straight or flaring necks and upright rims and bowls measuring 10 to $16 \mathrm{~cm}$ in diameter in the Teotihuacan Valley. Sherds recovered in most Texas missions are too small and too infrequently found to allow estimates of vessel shapes.

\section{Estimated Dates}

Charlton and Katz (1979:46) date the colonial version of this ware from 1650 to 1810 (see Figure 4-1). A more modern example of this ware is still being made in Tonalá today. 


\section{Place of Manufacture}

This ceramic type was produced in Tonalá in the Mexican state of Jalisco.

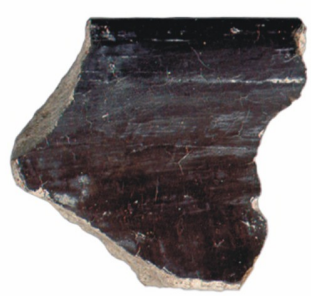

a

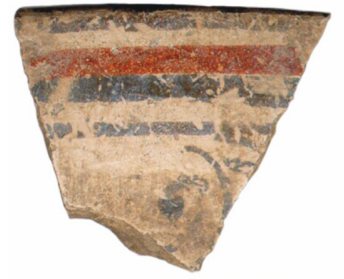

d

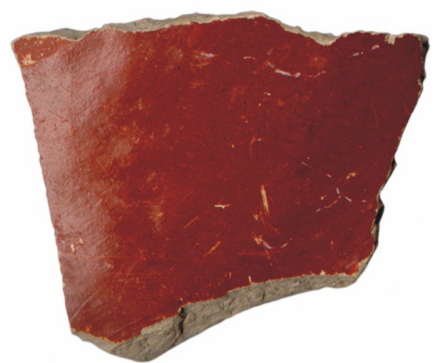

b
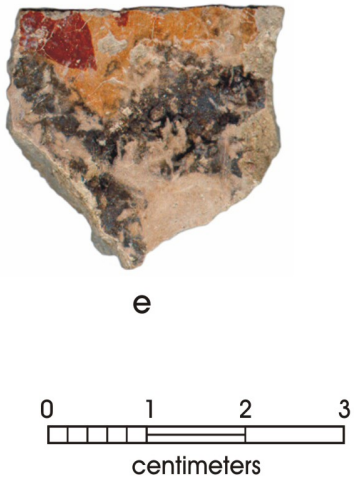

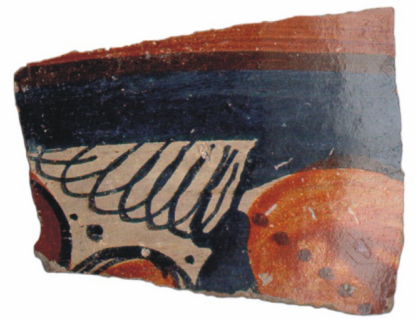

C

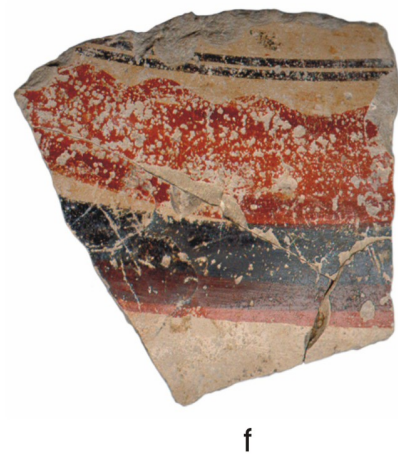

Figure 4-3. Tonalá Burnished. 41GD7:a, d, e; 41BX5: b, c; 41BX6: $f$. 


\section{RED BURNISHED}

This ware is defined on the basis of color and surface treatment. It has not been formally defined as a type. It was first described by Curtis Tunnell (Tunnell and Newcomb 1969:77-78) as found in Mission San Lorenzo in Camp Wood, Texas, and the Alamo in San Antonio (Greer 1967:17-18). Red Burnished wares have also been recovered from the other San Antonio missions, Presidio La Bahía, Mission Rosario, Mission Espíritu Santo, and Mission Refugio. Its distribution appears to be restricted to Texas.

\section{General Description}

These vessels are dark red, or occasionally black, with polished surfaces. The fine-grained, uniform red paste is coated with a thin, fine-grained slip that has been highly polished (Figure 4-4). Matte areas, on the interior of bowls and exterior of larger containers, are decorated with glossy, burnished spirals and curvilinear figures (Figure 4-4a-c; see also Gilmore 1974:63). The burnished surface tends to spall during firing, producing a white speckled appearance on many of the red sherds, as well as sometimes a light sprinkling of black. Similar to the Tonalá Burnished ware, this type of ceramic was handmade.

\section{Vessel Forms}

These are usually small bowls with slightly inverted rims and miniature strap handles just beneath the lip on the exterior. Some bowls have a tall, flaring foot ring averaging around $2.5 \mathrm{~cm}$ in height (Gilmore 1974:63; Tunnell and Newcomb 1969:78). Larger jars in the Presidio La Bahía collection have vertical rims with thickened vertical ridges spaced several centimeters apart. Sherds vary in thickness from $9 \mathrm{~mm}$ near the base to $5 \mathrm{~mm}$ at the widest part and thickening slightly to $6 \mathrm{~mm}$ just under the rim. The use for these vessels has not yet been determined.

\section{Estimated Dates}

This ware seems to be present through much of the eighteenth century (see Figure 4-1). The earliest finds come from the third site of Mission Espiritu Santo in Mission Valley, north of Victoria, Texas (Lakeman 2001:58). The site was used from 1726 to 1749 .

\section{Place of Manufacture}

This ware was probably manufactured in central Mexico according to Tunnell (Tunnell and Ambler 1967:24), although the exact location is unknown. Red Burnished ware has been found across Texas from Presidio Los Adaes (in Louisiana) (Gregory 1980:49) to El Paso (Gerald 1968) and was probably acquired by the procuradors of the mule trains that supplied the colonial sites (Fox 2002:204). 


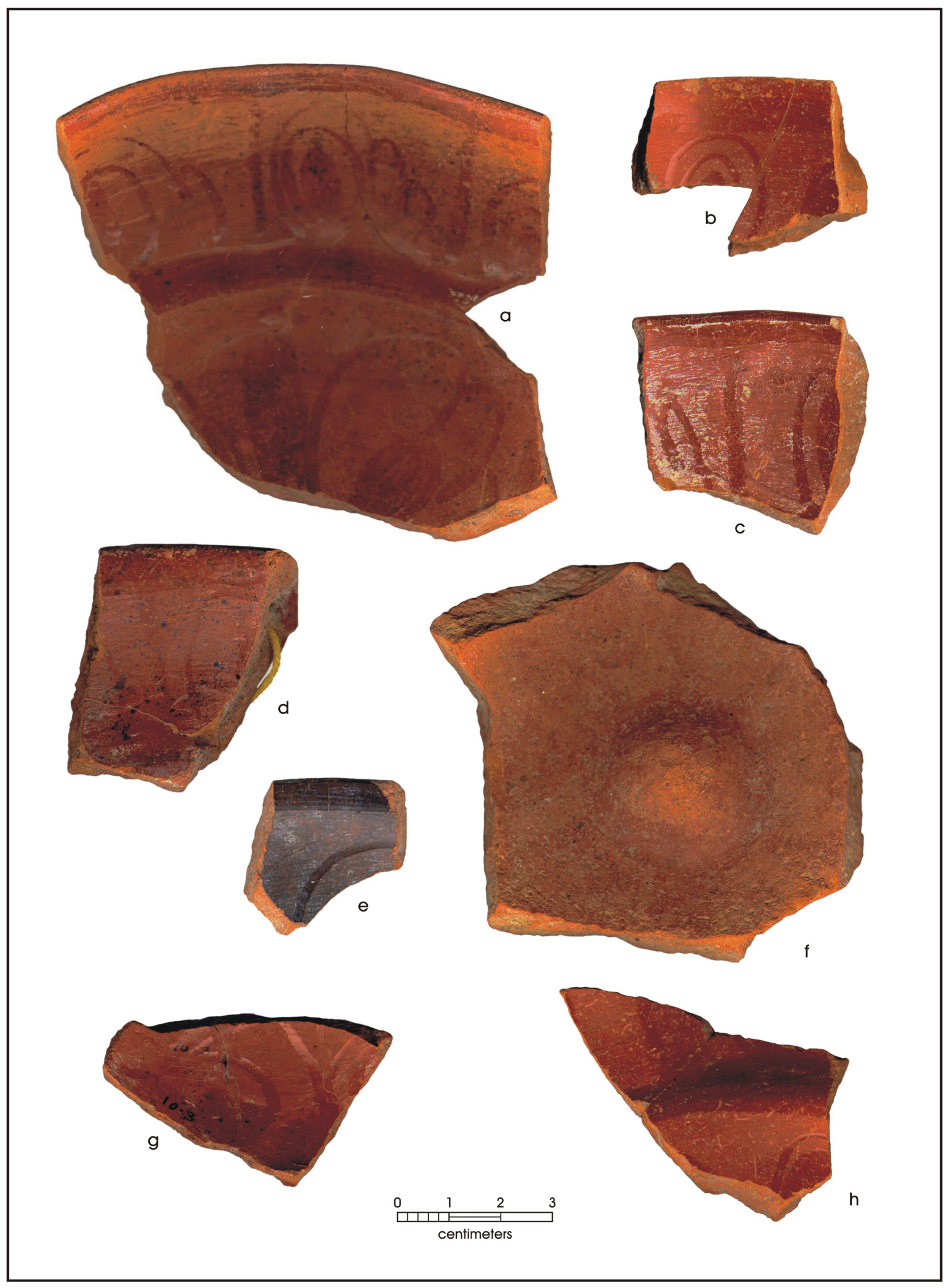

Figure 4-4. Red Burnished. 41GD7: a, c, d; 41BX5: b, e-h.. 


\section{SANDY PASTE LEAD-GLAZED WARES}

Detailed analysis of lead-glazed wares in Texas sites was done by A.A. Fox in 1974 for the collection from Mission Rosario, near Goliad, Texas (see Gilmore 1974:55-59). Microscopic examination of these wares allowed division into sandy paste and fine paste types. Descriptive names were given to wares that could be differentiated from each other by color and/or texture of the glaze.

\section{YELlOW GLAZE AND GREEN GLAZE I}

This ware was first separated from the other Mexican Lead-Glazed wares by Curtis Tunnell (Greer 1967:20-21) who identified it as Light Yellow. In 1974, Fox used the term Yellow Ware to separate and further describe this ware (Gilmore 1974:56). This ware has been found at the Spanish Colonial sites in San Antonio, Texas.

\section{General Description}

Vessels of this ceramic ware generally display obvious signs of the use of a potter's wheel (Figure 4-5a, e). Walls are relatively thick, often as thick as $10 \mathrm{~mm}$. A yellow-tinted lead glaze of varying thickness (Schuetz 1968:53) covers the interior of bowls (Figure 4-5), occasionally spilling onto the outside. The paste is generally sandy and coarse and ranges from rose-beige to orange with red-brown inclusions. Some bowls bear sparse green decoration or green rim bands. These vessels sometime occur with a green glaze rather than yellow (Figure 4-5d).

\section{Vessel Forms}

Vessel forms that have been noted in the archaeological and historical records include deep bowls, jars, and pitchers. The vessels appeared to have been heavy and thick-walled, which probably held up well in transit from Mexico to Texas. These thick lead glazed vessels would have been sturdy utilitarian wares.

\section{Estimated Dates}

Sandy pasted lead glazed wares were produced throughout the eighteenth century (see Figure 4-1).

\section{Place of Manufacture}

The sandy pasted lead glaze wares were imported from Mexico, though the exact location of manufacture is not known. 


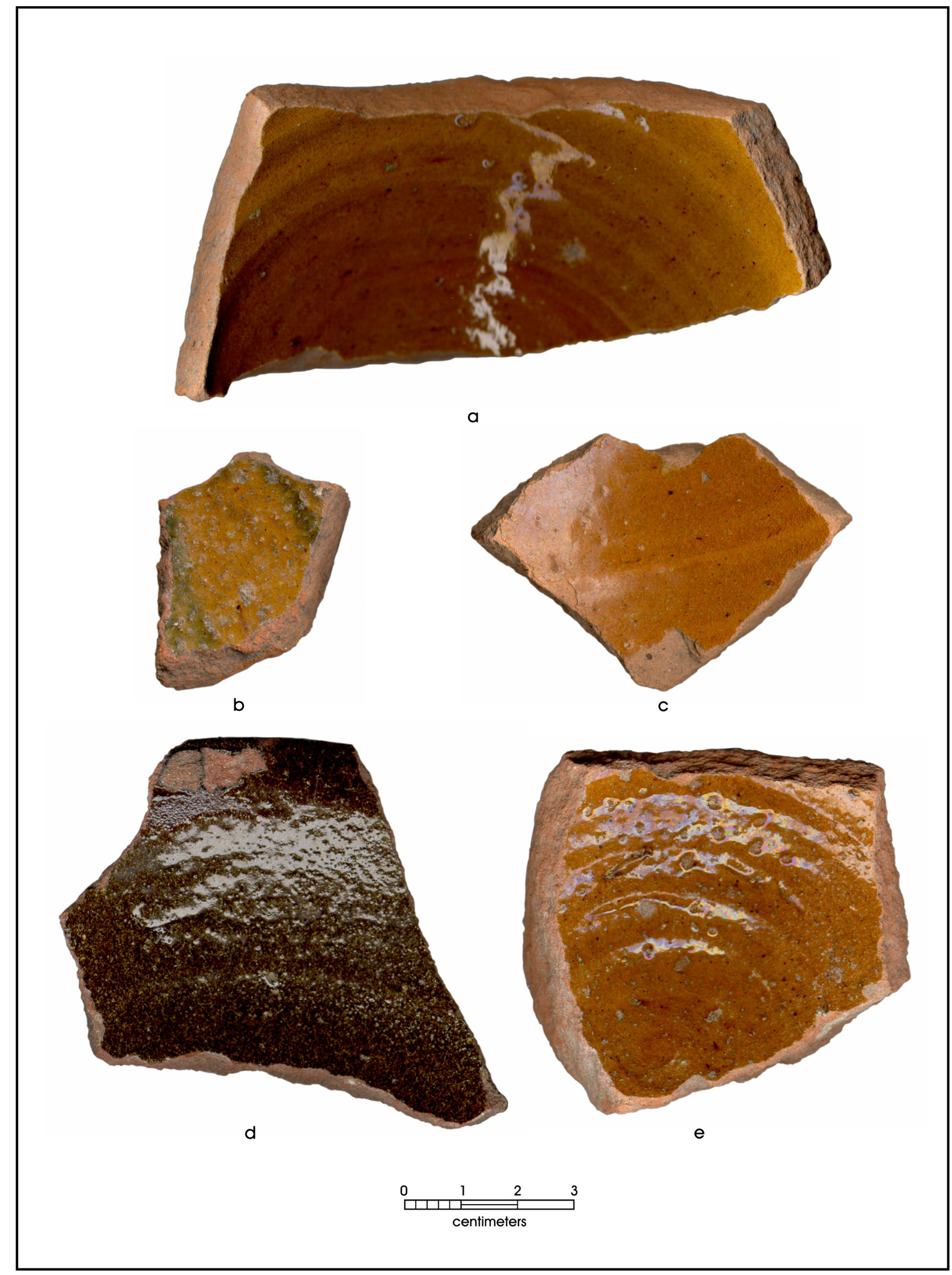

Figure 4-5. Yellow Glaze and Green Glaze I. 41BX5: a, d, e; 41BX3: b; 41BX4: c. 


\section{YELLOW GLAZE AND GREEN GLAZE II}

These sandy pasted lead glazed wares are thinner $(3 \mathrm{~mm}$ to $5 \mathrm{~mm}$ ) than the Yellow Glaze and Green Glaze I wares. The glaze is thinner, as well, and is found over a somewhat finer-textured paste.

\section{General Description}

Bowls of this ware are often decorated with green bands around the rim and in the bottom (Figure 4-6). There is a great variety in the vessel forms and decoration of these sandy paste lead-glazed wares. All of the varieties appear to have been intended for kitchen use. Colors of the glaze vary from pale yellow over orange paste to dark green over gray paste.

\section{Vessel Forms}

Typical vessel forms included bowls, jars, and pitchers. Occasionally, the ware also contains simple candleholders made in imitation of copper ones.

\section{Estimated Dates}

This ceramic ware was produced throughout the eighteenth century. Two large, splayed bowls of this type were recovered from a post-1772 context at Rancho de las Cabras, near Floresville, Texas (Ivey 1983). Other examples of the ware were encountered at Mission San Juan de Capistrano and Mission Concepción.

\section{Place of Manufacture}

These vessels were also produced in Mexico, although the location is undetermined. 


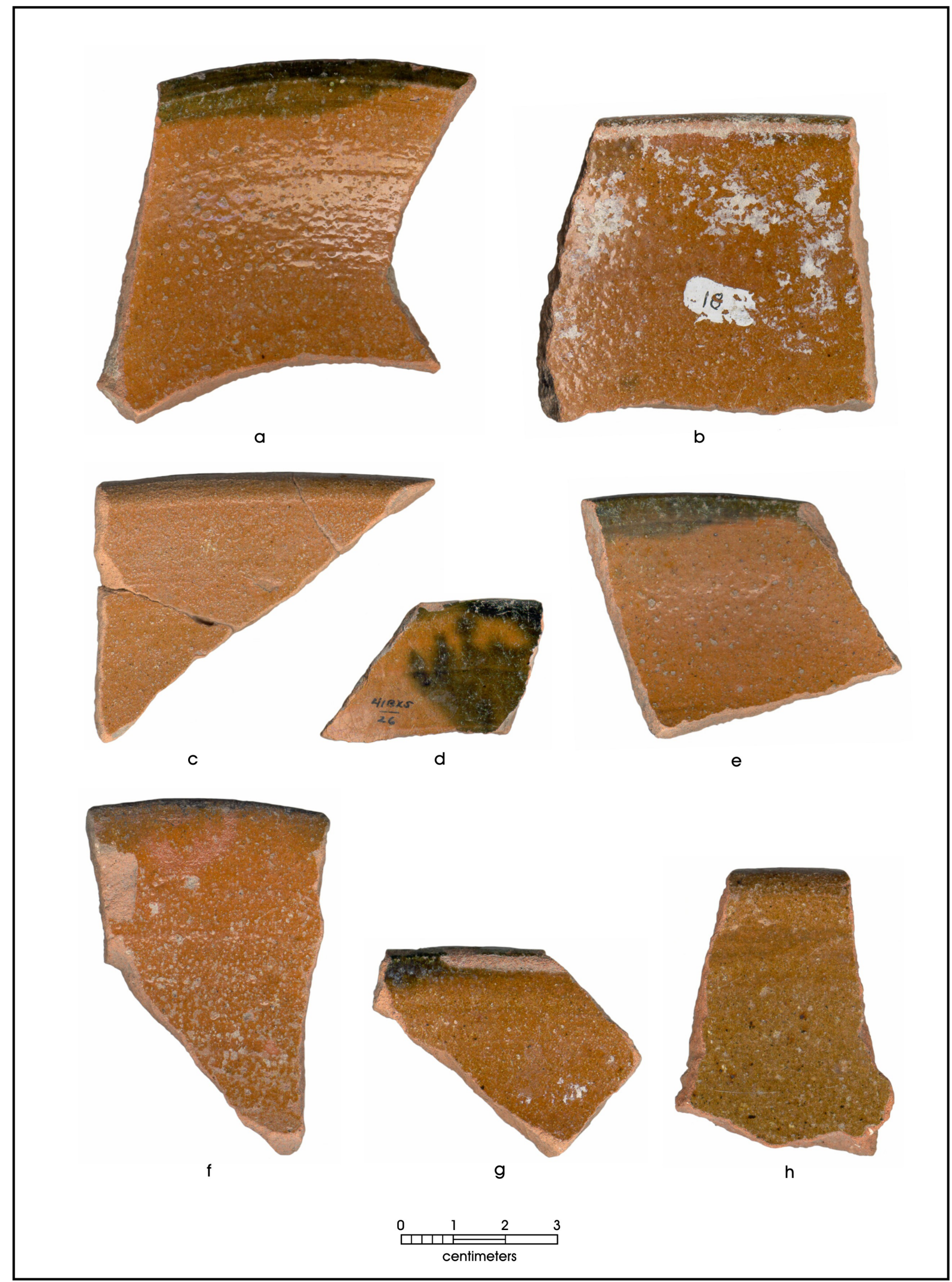

Figure 4-6. Yellow and Green Glaze II. 41BX5: a-g; 41BX4: $h$. 


\section{FINE PASTE LEAD-GLAZED WARES}

\section{GALERA}

This term has come into use across the Southwest since the first half of the twentieth century. It was first used in Texas by Gerald (1968:53-54), who suggested that the type is still used by people who continue to buy similar wares in Mexico. Schuetz (1969:50-51) has called this West Mexico Polychrome. Galera ware is commonly found at most mission, presidio, and villa sites in Texas. We are not certain of the relationship of this ware to the similarly named ware in California (Krase 1981).

\section{General Description}

Ceramic vessels of this type are often molded rather than wheel-thrown. The body is thin, averaging 3 to $4 \mathrm{~mm}$ in thickness and tends to break into small sherds. A thin lead glaze enhances the orange color of the paste. The glaze is generally on the interior and over the rim and the upper body. Designs in cream, brown, and green appear (Figure 4-7) on the upper exterior surfaces of chocolateras and the outside of bean pots and serving dishes. Typical motifs include dots, feathers, and small flower-like designs (Figure 4-7).

\section{Vessel Forms}

Common forms of Galera wares include chocolate pots with constricted necks and bulbous bases, and bean pots of various shapes. Other forms encountered include serving dishes (i.e. plates and platters) and tazas (cups). Thin strap handles are common (Figure 4-7 a, d). Chocolate pots often have pinched pouring spouts on the rim similar to those of pitchers.

\section{Estimated Dates}

Ceramic chocolate pots appear to have abruptly replaced similar copper vessels about 1750 (Tomka and Fox 1998:22). No information is available on bean pots and other serving dishes, although archaeological records indicate their presence in Texas during the early part of the eighteenth century into the midnineteenth century. Here we suggest a date range of 1725 to 1850 (see Figure 4-1). Similar wares are still produced and can be found in many areas of Mexico today.

\section{Place of Manufacture}

Galera ware appears to have originated from the state of Jalisco, probably from the town of Tlaquepaque, a suburb of Guadalajara (Gerald 1968:54). It is possible that the type may have been produced in other towns as well. 


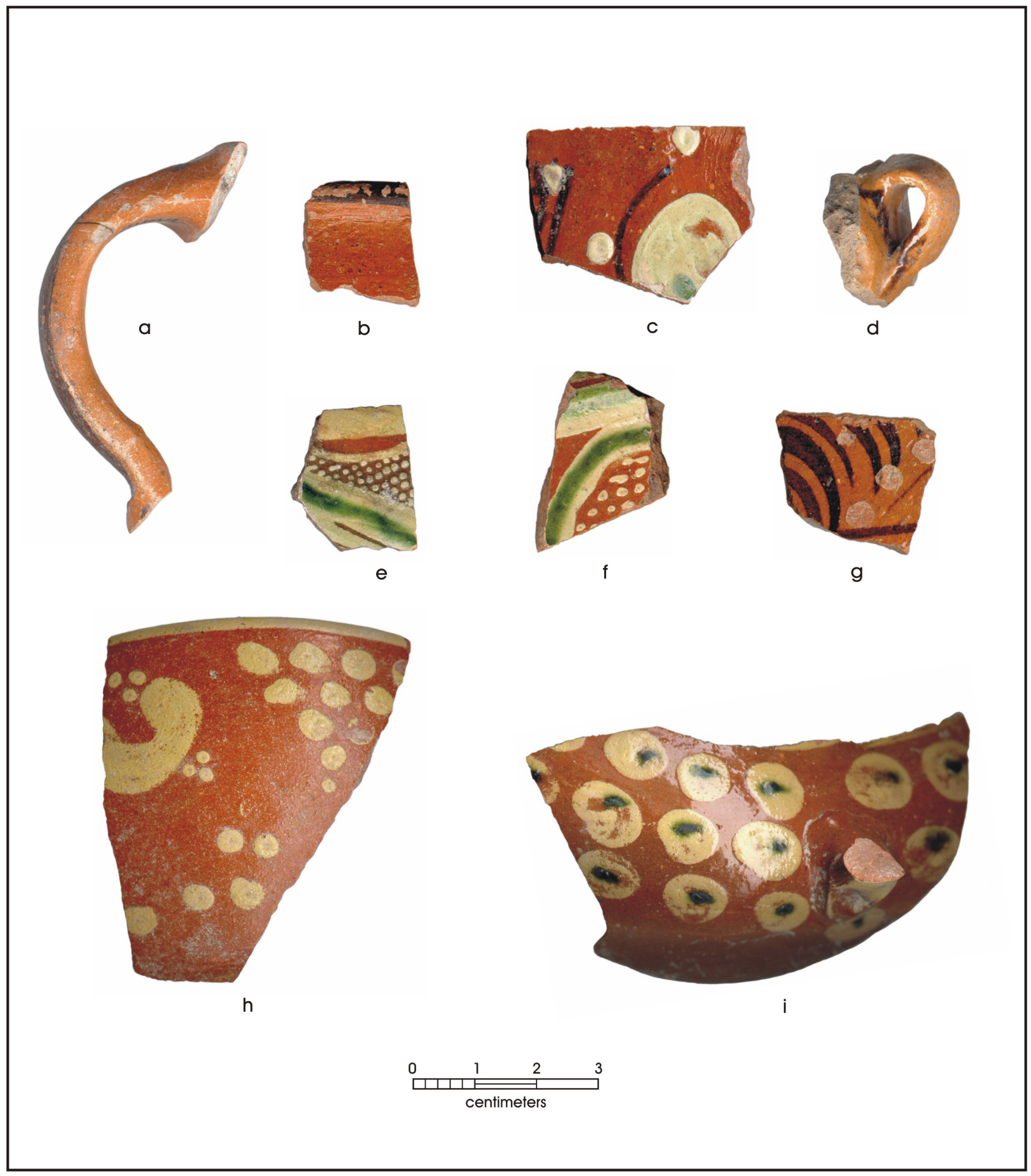

Figure 4-7. Galera. 41GD7: a, e, g-i; 41BX4: f; 41BX5: c, $d$; 42BX6: b. 


\section{RED BROWN}

Schuetz (1969:51) has referred to this as Guadalajara Ware, but does not identify a source for this information. Typically, the term "Guadalajara Ware" has been associated with Tonalá Burnished. Red Brown ware has been encountered at Presidio La Bahía, and Mission San Juan de Capistrano, as well as the other missions of San Antonio.

\section{General Description}

This ware has a red-brown-tinted lead glaze over a fine red-brown paste. Shallow throwing rings show up distinctly on the upper surface of sherds (Figure 4-8). The thin lead glaze can be found on the interior only, or on both the interior and exterior of the vessel.

\section{Vessel Forms}

A flat-based form with gently sloping sides that curve inward could be from shallow plates (Schuetz 1980:74). Other rim sherds curve gradually outward similar to the necks and rims of yellow lead-glazed jars. Shallow bowls also appear to be a common form. A basal fragment has a flat bottom, as if a pancake were applied to the bottom of a shallow plate. Sherds vary in thickness from 4 to $6 \mathrm{~mm}$ and are generally too small to be able to reconstruct vessel shapes or sizes.

\section{Estimated Dates}

Red Brown wares are present in Texas throughout the eighteenth century (see Figure 4-1).

\section{Place of Manufacture}

This ceramic ware was produced in Mexico, although the exact location is unknown. 


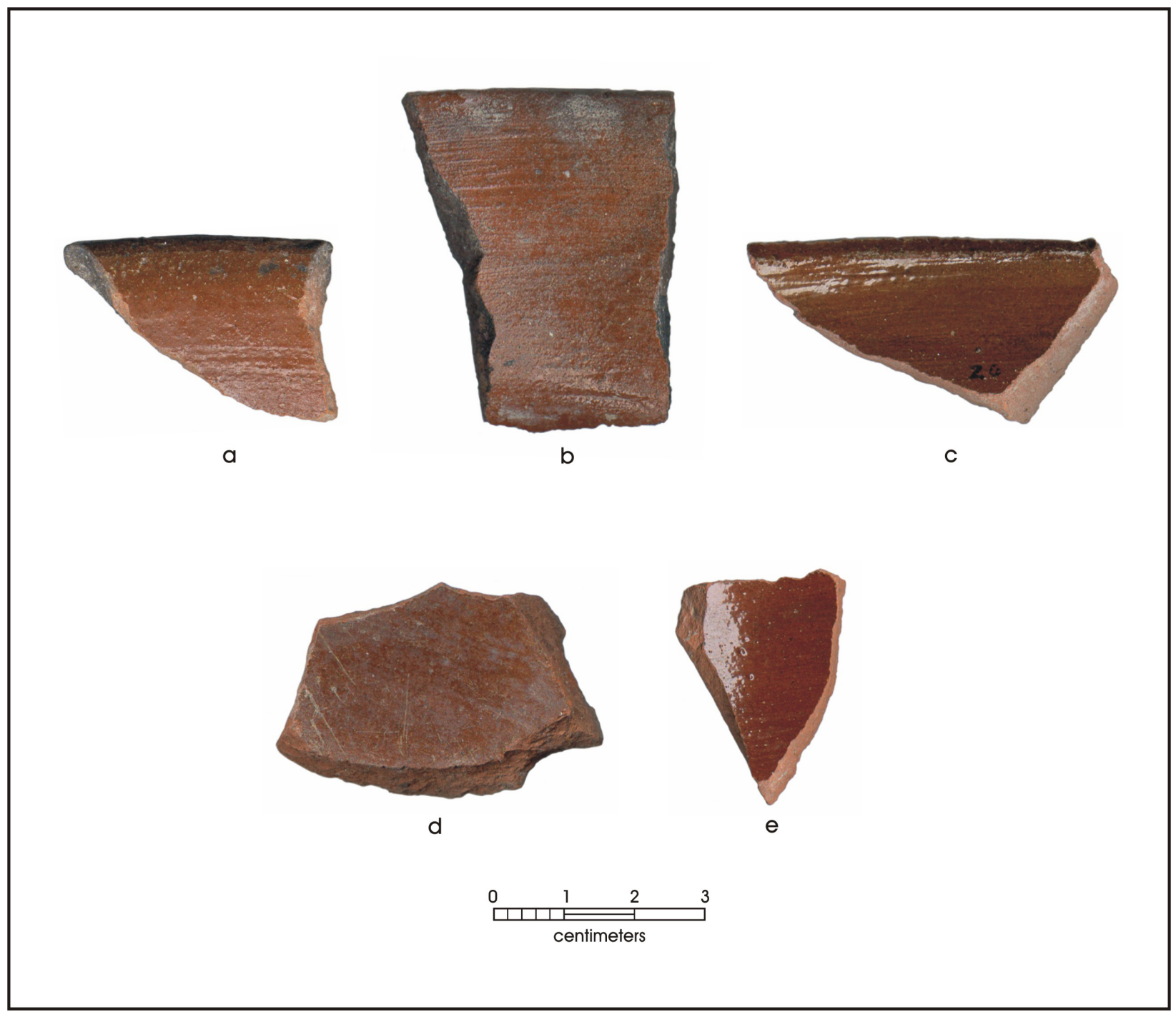

Figure 4-8. Red Brown. 41GD7: $a, b, d ; 41 B X 5: c$, e. 


\section{DARK BROWN}

This is similar to Galera type in paste, color, texture, wall thickness, and construction technique. It was first separated from the other lead glazes (Fox 2002:207) after finds of bulbous ceramic fragments from Presidio La Bahía in Goliad, Texas. Since then, it has been recovered at Mission Rosario near Goliad, Mission San Juan Capistrano in San Antonio and Mission Refugio near Refugio.

\section{General Description}

The darker brown color suggests that the glaze is brown or that a brown slip has been applied under the glaze to create a molasses color. The glaze on the exterior does not appear to have been equally applied, resulting in areas of thicker glazing on the vessel. Interior glazing is not uniform and ranges in color from clear to green. Striations resulting from production on a wheel are visible on the interior wall of the vessels. Decoration takes the form of a row of impressed dents around the shoulders of the vessels (Figure 4-9c). The paste is uniformly red-orange.

\section{Vessel Forms}

Bulbous pots are $13 \mathrm{~cm}$ in diameter at the base of a short neck, with a slightly everted rim. All sherds recovered so far seem to be from such vessels. They are remarkably thin, averaging $3 \mathrm{~mm}$ in thickness. They appear to have at least one vertical circular handle attached between the neck and the shoulder and measure about $11 \mathrm{~mm}$ in diameter at the rim.

\section{Estimated Dates}

Based on the dates of operations of the missions where it has been found (Mission Rosario [1754-1808], Mission San Juan Capistrano [1731-post-1900], and Mission Refugio [1795-1830], the ware was probably in use from the middle to the late eighteenth century and possibly a bit later. We suggest a date range of from about 1750 to 1830 (see Figure 4-1).

\section{Place of Manufacture}

The exact location of manufacture is unknown, although western Mexico is a possible area. 

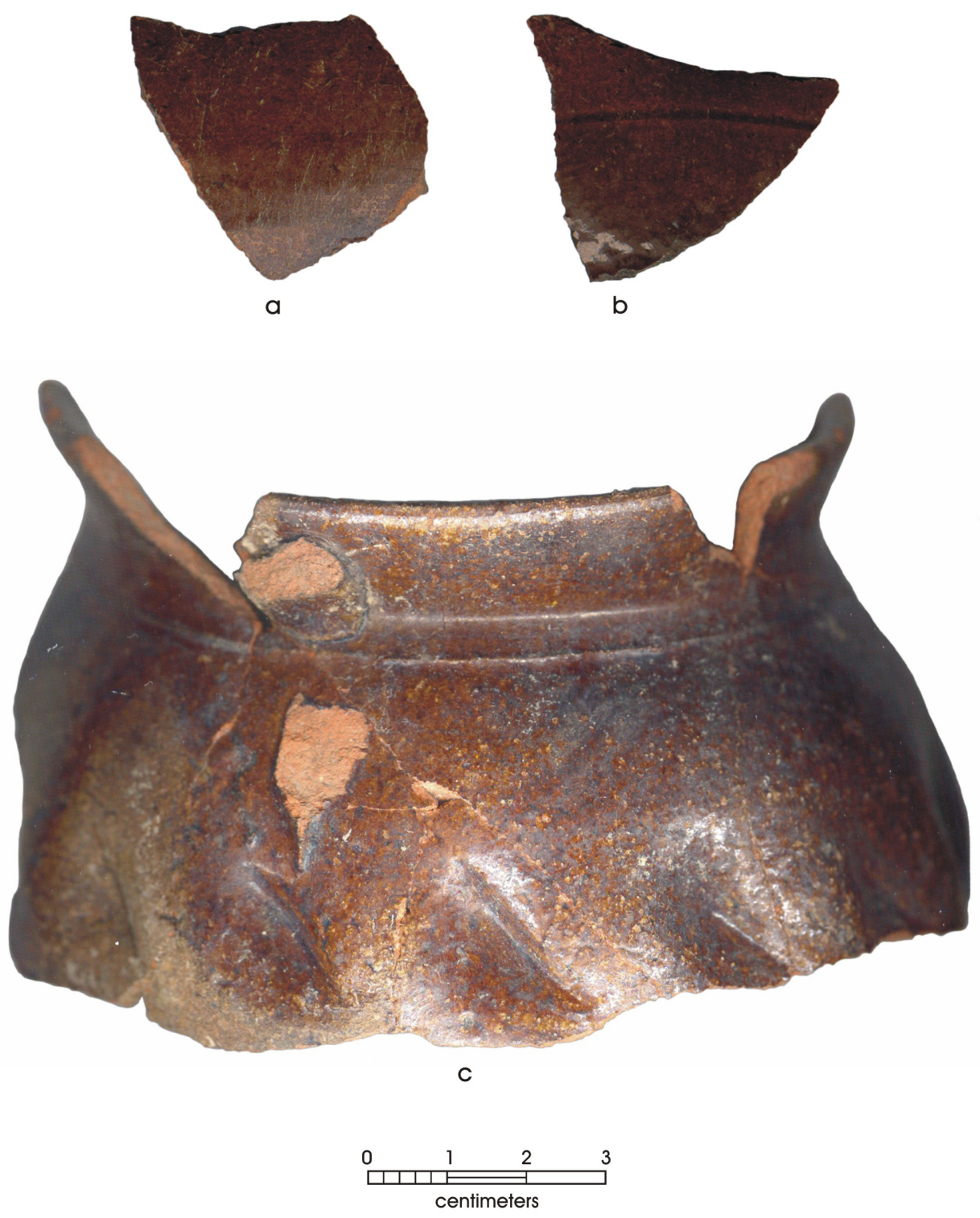

Figure 4-9. Dark Brown. 41RF1: $a, b ; 41 G D 7: c$. 


\section{SMOOTH BROWN}

Sherds of this ware are found at historic San Antonio sites, although not as commonly as other wares. Some of the sites with collections of this ware date to the early nineteenth century. Mission sites that were occupied after their secularization in the 1790s also contain examples of this ware. A few sherds are also found in the Presidio La Bahía collection. Its distribution appears to be limited to Texas Spanish Colonial sites.

\section{General Description}

The red fine-grained paste is covered on both sides with a smooth, transparent lead glaze, usually thicker on the inside of a vessel, which allows the body to show through. Decoration generally consists of one or more narrow dark brown bands and/or vertical slashes on the interior (Figure 4-10a, b, d). Wall thickness of this ware is generally greater than that of the Dark Brown Ware.

\section{Vessel Forms}

Common vessel forms encountered include shallow bowls and plates with flat bases and no foot rings.

\section{Estimated Dates}

Exact dates of manufacture are unknown. Smooth Brown probably dates from around 1775 to about 1830 (see Figure 4-1).

\section{Place of Manufacture}

Manufacture of this ware may have occurred in Mexico. 


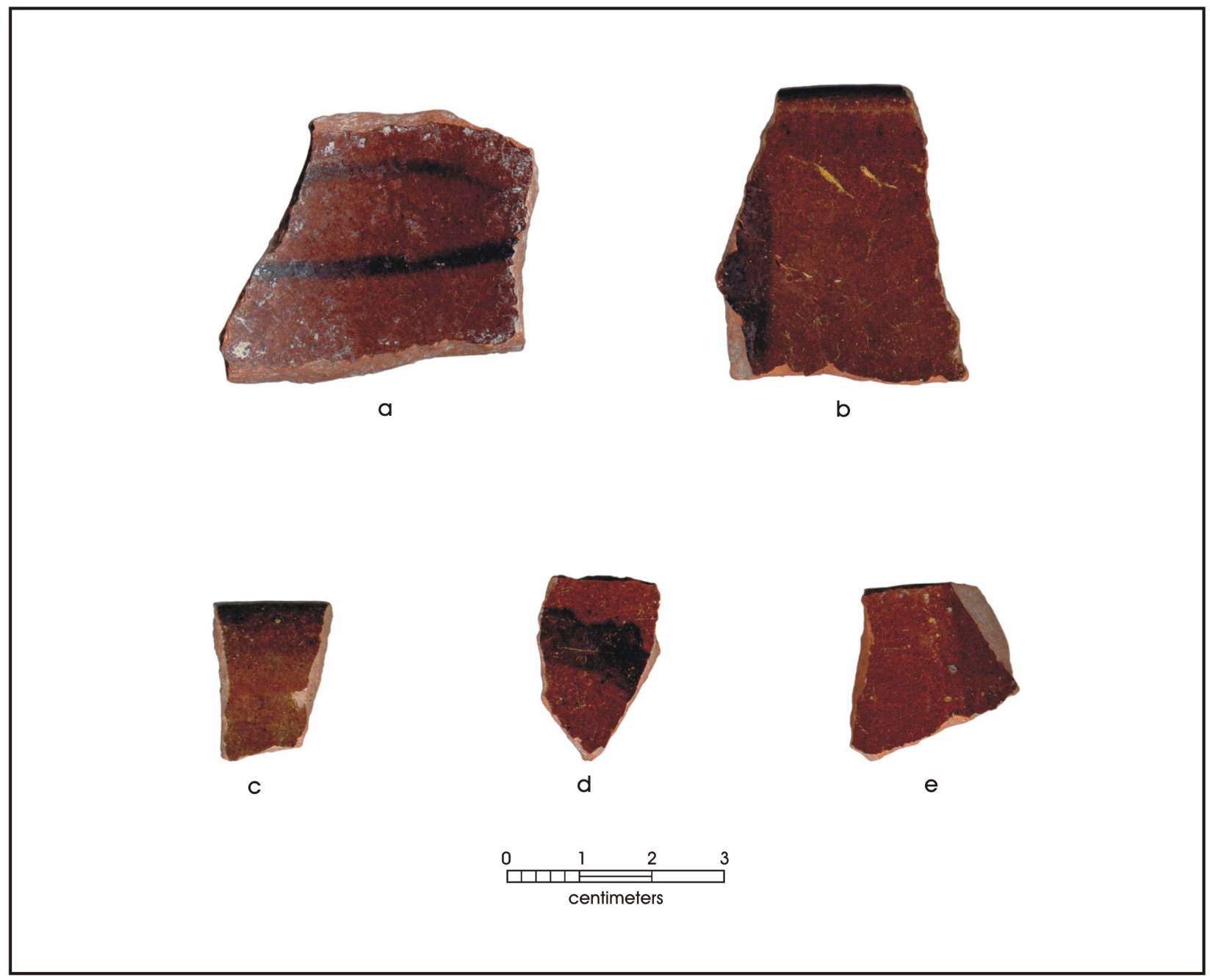

Figure 4-10. Smooth Brown. 41GD7: a-c, e; 41BX5: d. 


\section{BROWN ON YELLOW}

This ware is found less frequently than other lead-glazed wares on Texas colonial sites. The distribution of the ware appears to be limited to Texas. Though not found as often, when encountered the larger fragments allow the reconstruction of some vessel forms.

\section{General Description}

This fine-grained paste is yellow to orange when damp, and the lead glaze may possibly be colorless, merely enhancing the paste color. The glaze covers the inside and goes slightly over the top of the rim. The glaze does not age well and often appears pock-marked. Swirling brown designs were applied under the glaze, and brown dots occur around the top of the rim (Figure 4-11). Some vessels appear to have been molded, while others were wheel-thrown.

\section{Vessel Forms}

One form encountered is a shallow plate with a slightly upturned rim and a small ring foot. Another form that has been observed is a small bowl, with interior glazing spilling over the rim, brown designs appearing as brush strokes, and a flat base with no foot ring.

\section{Estimated Dates}

This ceramic type seems to date between about 1750 and 1825 (Figure 4-1).

\section{Place of Manufacture}

Brown on Yellow Ware is probably produced in Mexico. The precise location of its manufacture is unknown. 


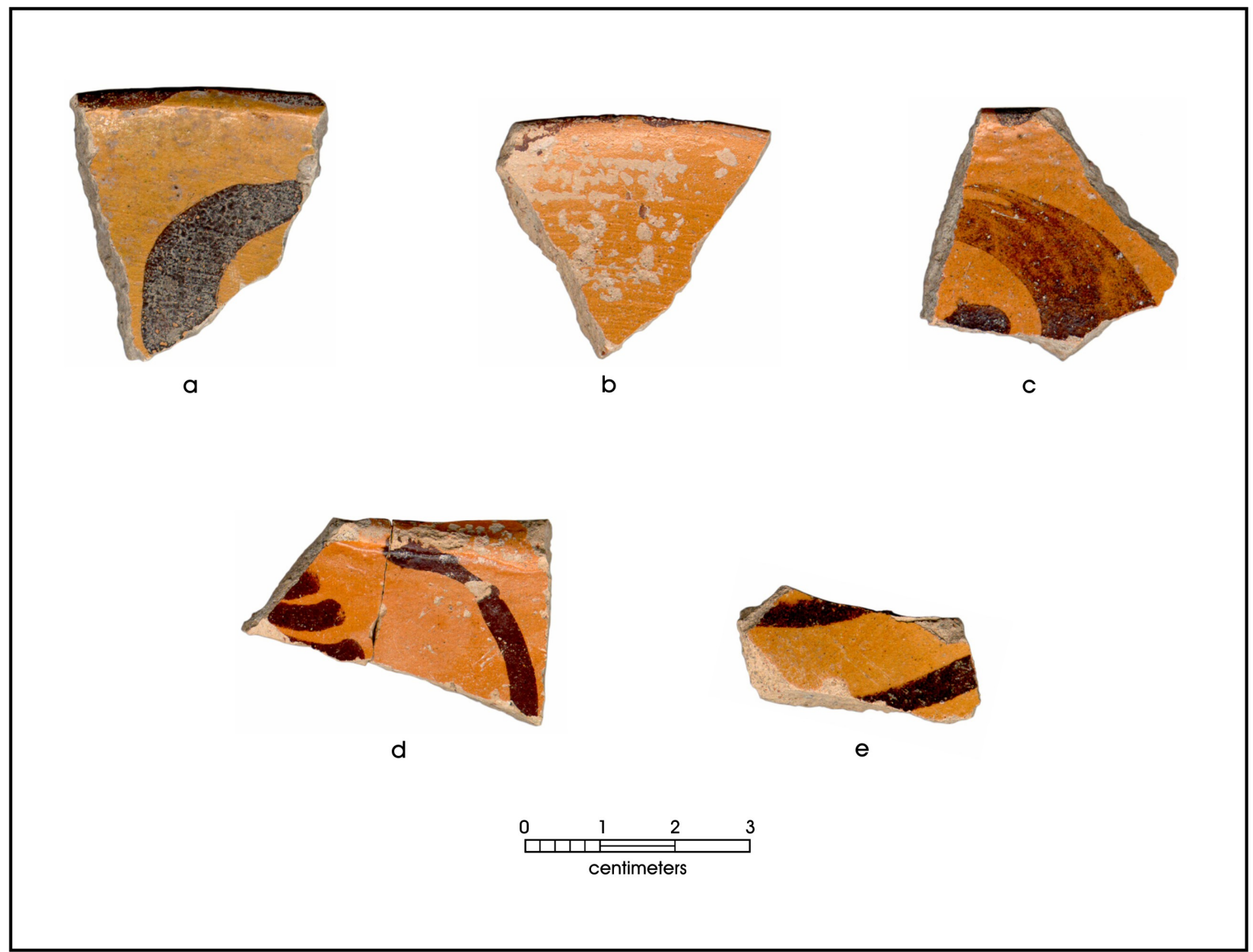

Figure 4-11. Brown on Yellow. 41GD7: b-e; 41BX5: a. 


\section{TONALÁ GLAZED}

This type is just one of a number of wares traditionally made in Tonalá. The clay used appears to be the same as in Tonalá Burnished, but this ware differs due to the addition of a glaze over the slip and the use of different colors and design motifs. This type has been recovered from Presidio La Bahía, Mission San Antonio de Valero, Mission San Juan de Capistrano, and Mission Refugio. Tonalá Glazed was first identified in Arizona and given the name "Tonalá ware" (Barnes 1980:101-2) in reference to the location of manufacture. Here we refer to it as Tonalá Glazed Ware to remove the possible confusion with its burnished cousin.

\section{General Description}

The paste tends to be browner than Tonalá Burnished wares. A white or cream-colored slip covers both surfaces. Green, red-brown, and black designs are painted on the inside surface and the vessel is then covered with a clear lead glaze (Figure 4-12). The decorated slip does not bond well with the paste, resulting in frequent flaking and exposure of the surface of the paste after years of burial in the soil (Figure 4-12a, c). Similar to the Tonalá Burnished, the odor of the paste when damp is unique and diagnostic.

\section{Vessel Forms}

Schuetz recovered a sufficient number of relatively large sherds at the Alamo (41BX6) to be able to estimate the form as a shallow bowl with a ring foot (Schuetz 1973). The sherds are nearly always very small and therefore difficult to assign to a vessel shape.

\section{Estimated Dates}

This ceramic type began to appear after 1780 in northern Sonora and Arizona (Caywood 1950:85). Gerald (1968:54) found it in late eighteenth-century presidios in northern New Spain, and suggested it was in use from 1780 to 1830 (see Figure 4-1). An unusually large number of sherds of this type were found at Mission Refugio in Refugio, Texas. Mission Refugio was the last mission in operation in Texas, closing in 1830 .

\section{Place of Manufacture}

This ceramic type was produced at Tonalá, outside of Guadalajara, in the modern Mexican state of Jalisco. 


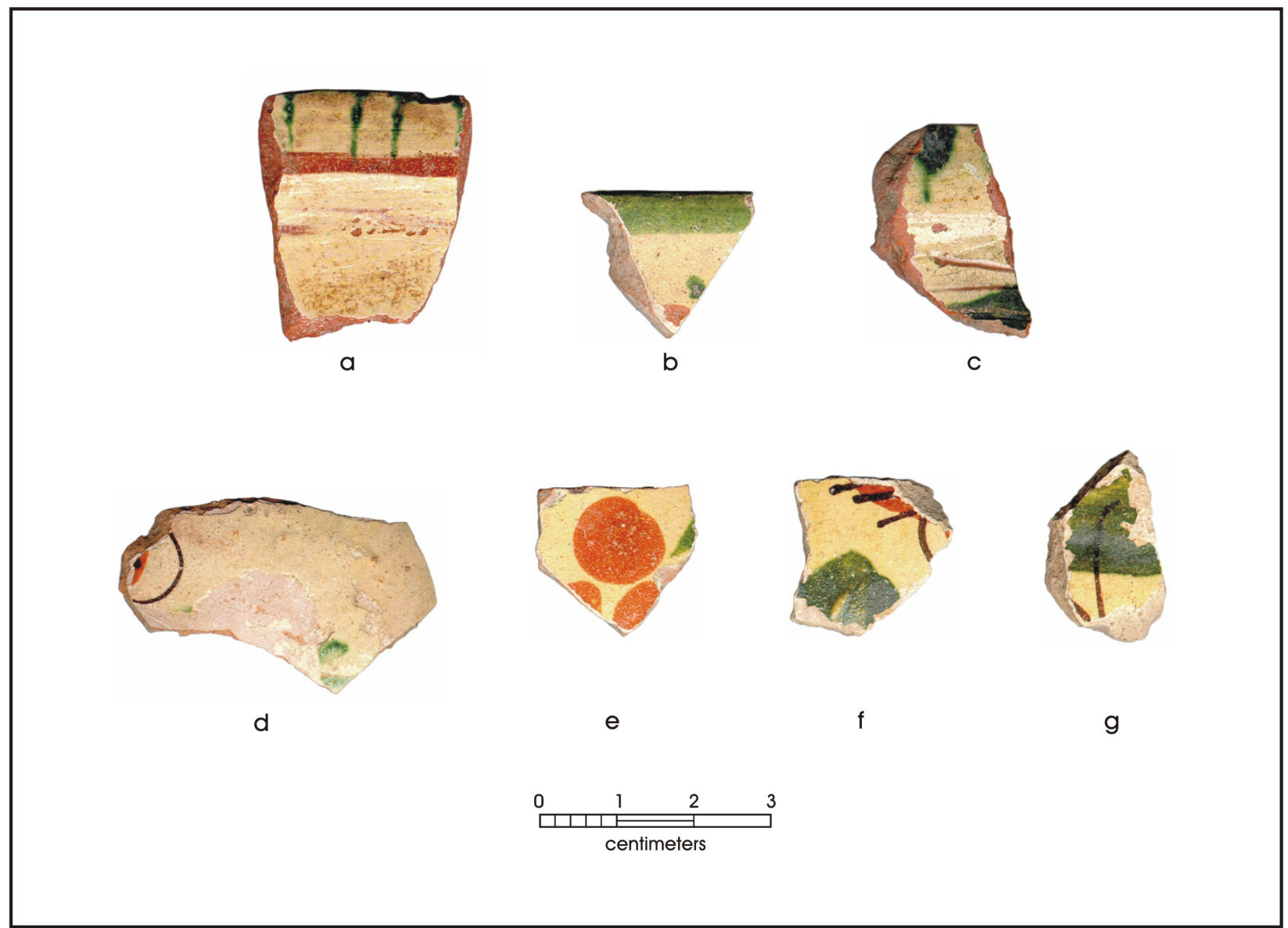

Figure 4-12. Tonalá Glazed. 41GD7: a, c: 41RF1: e-g; 41BX5: d; 41BX6: b. 


\section{BLACK LUSTER GLAZE}

This ware was first reported in Texas by Schuetz (1969:52) in collections from Mission San Juan Capistrano. The number and size of the sherds were too small to allow reconstruction of body shapes. She did report that there have been two Black Luster types made in Mexico, each in a different town. Black Luster has been recovered from the San Antonio Missions, and Mission Rosario, Mission Espiritu Santo, Presidio La Bahía, and Mission Refugio.

\section{General Description}

The glaze on this ware is intensely black and shiny (Figure 4-13), and is often stamp-decorated or embellished with molded high relief (Figure 4-13d) (Schuetz 1969:52). Sherds recovered from most mission sites are few and very small. The paste can be found in either terra cotta or buff color.

\section{Vessel Forms}

Schuetz (1980: Figure 22) recovered enough sherds of this ware to be able to reconstruct some forms representing deep bowls with everted rims. The few sherds in Texas collections measure from about 3 $\mathrm{mm}$ to $5 \mathrm{~mm}$ in thickness.

\section{Estimated Dates}

Barnes (1980:100) reports that wares characterized by black glaze on a reddish body were made in the town of Santa Fe in the state of Michoacan, between 1750 and 1850 (see Figure 4-1).

\section{Place of Manufacture}

According to Schuetz (1969:52), a similar black luster glazed ware was manufactured on a terra cotta body in Puebla. Further research is needed to ascertain the place or places of manufacture of this ware. 


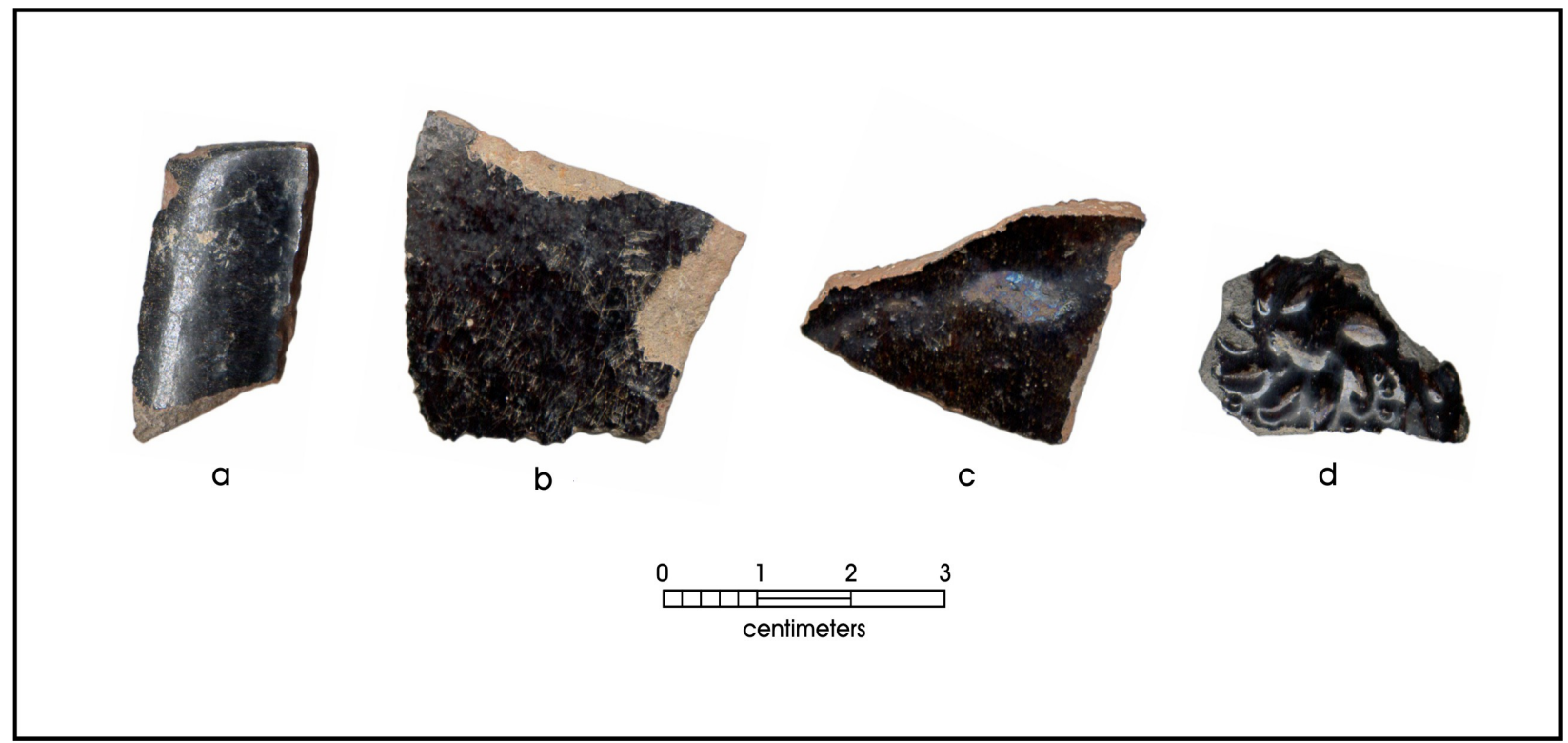

Figure 4-13. Black Luster Glaze. 41GD7: a, b, d: 41BX5: c. 


\section{OLIVE JARS}

Olive Jars were used to ship liquids such as wine and olive oil to the New World (Avery 1997:221; Goggin 1964:256). Fragments of these vessels have been recovered at the San Antonio missions, as well as Presidio Loreto. We have not endeavored to place the Spanish Colonial olive jar sherds found in Texas missions into types.

\section{General Description}

These were large, heavy egg-shaped jars with restricted necks. They were often glazed on the inside with a lead glaze varying from emerald to olive green and sometimes the outside had a thin white slip. The paste is usually reddish to pale tan in color. In Texas collections, the paste seem to be universally light tan to cream and only occasionally reddish (Figure 4-14). Small numbers of olive jar sherds are found on Texas colonial sites, but they are numerous on coastal sites in Florida and the southeastern United States. On the frontier, they appear to have been used primarily for storage.

\section{Vessel Forms}

John Goggin (1964) distinguished three basic body types (A, B, and C) and designated form types within these. Sherds are thicker than those of other ceramic wares, varying from $5 \mathrm{~mm}$ to $9 \mathrm{~mm}$ depending on the part of the jar represented. The forms shown previously in Figure 3-2 are based on jars found in eighteenth century shipwrecks (Marken 1994:94-98).

\section{Estimated Dates}

John Goggin (1964) divided the three body types into "Early" (1490s to 1580), "Middle" (1580 to 1780), and "Late" (1780 to 1800s) styles. However, Avery (1997:128) disagrees with the date ranges for some of Goggin's body types. The olive jar sherds found on Texas sites generally fall into the Middle style (see Figure 4-1).

\section{Place of Manufacture}

These vessels were used for the importation of products not made in the New World. The place of manufacture was most likely in Andalusia, Spain (Lister and Lister 1987:141). 


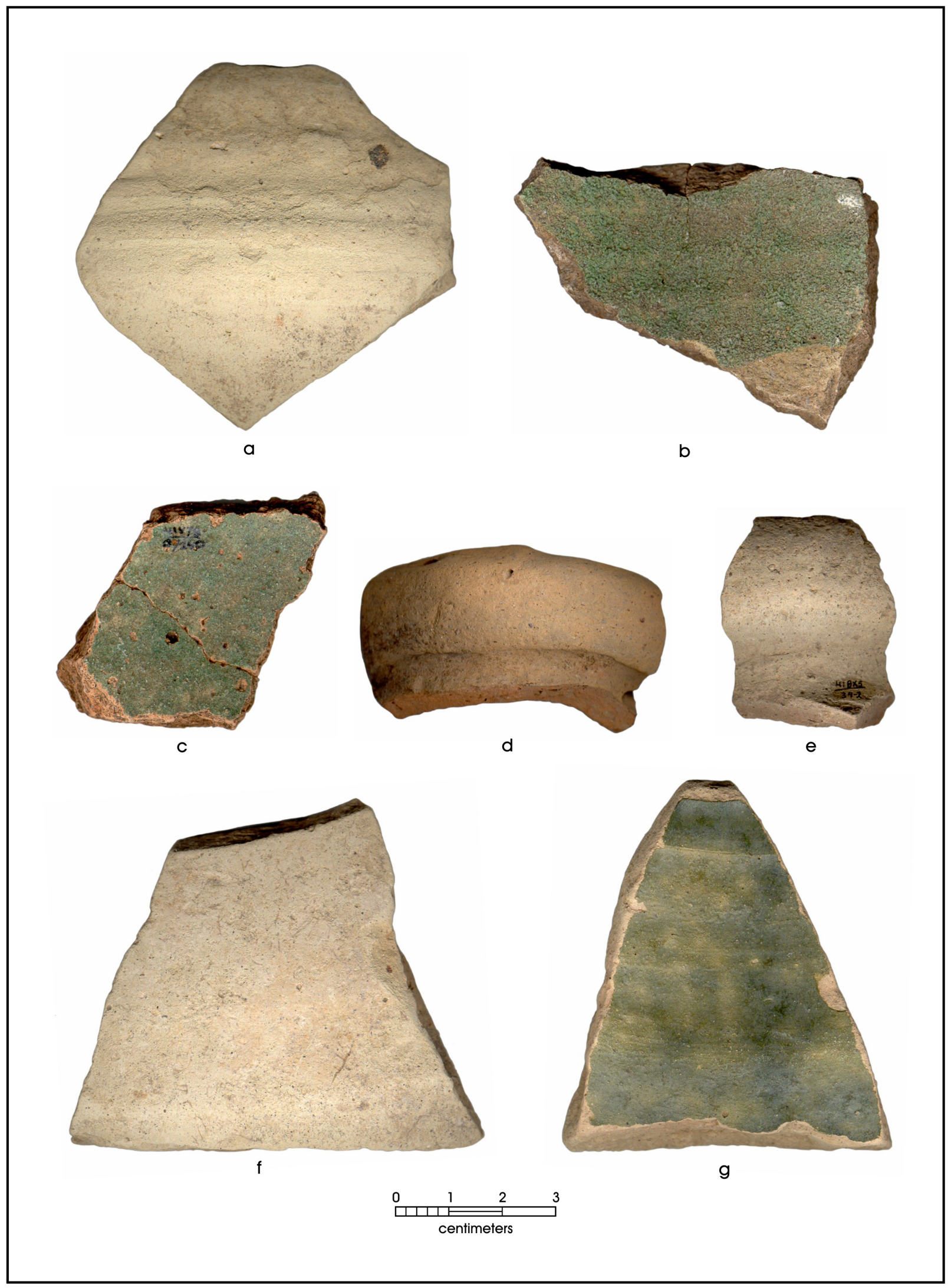

Figure 4-14. Olive Jars. 41BX5: $a, b, e-g ; 41 V T 8 c, d$. 


\section{MEXICAN TIN-GLAZED WARES}

All Mexican tin-glazed vessels, commonly called majolicas, were made on a potter's wheel and fired in a kiln. They then were covered with a lead glaze to which tin had been added to produce an opaque surface when fired. After drying, a design was painted on one or both surfaces and the vessel was again fired.

One of the first descriptions of colonial ceramics on sites in the Southwest was done by Louis Caywood (1950:77-97). Fifteen years later, David Snow (1965:25-35) began to arrange tin-glazed wares in the Southwest into chronological order and to use type names. Before long, archaeologists in Texas (Gilmore 1973; Schuetz 1969; Tunnell 1966) were recognizing individual patterns among the tin-glazed sherds, but hesitated to assign distinctive type names. By 1968, Yale University had published a book (Goggin 1968) that soon became the resource for identification and dating of tin-glazed wares in Texas. Further work in Texas has enlarged and improved our familiarity with tin-glazed wares. Below, the majolicas will be organized in rough chronologic order. Finally, references to French-made tin-glazed wares, commonly called faience, and Chinese porcelain, both of which are recovered from Spanish Colonial sites, are presented.

\section{Late Seventeenth Century to Early Eighteenth Century}

\section{Castillo Polychrome}

Schuetz (1969:54) reported that a few fragments of this type were recovered from Mission San Juan de Capistrano in San Antonio, Texas. Excavations conducted at the Spanish Governor's Palace (41BX179), also in San Antonio, produced a few small sherds (Figure 4-15). Castillo Polychrome is a rare type in Texas, due to its early date. The type was defined by Goggin (1968:183-186) and is present in late seventeenth-century components in Florida (Deagan 1987:81-82). It is considered a variety of the Puebla Polychrome type in the California classification (Cohen-Williams and Williams 2004:8, 34-35).

\section{General Description}

This type has naturalistic designs in a medium blue color, though the shade can be another variation of cobalt, on a white glossy background. Thin dark blue or black lines and dots accent the designs, distinguishing it from a similar type, San Agustín Blue on White. Blue loops are found on the exteriors of plates (Figure 4-15). Typical motifs found on Castillo Polychrome include floral designs and depictions of birds (Goggin 1968:184). The paste is cream to white in color. Sherds of this type are seldom found on Texas sites, and then only in the earliest sites, sometimes accompanied by Puebla Polychrome. 


\section{Vessel Forms}

Goggin (1968:185) mentions only plates (platos) with a low ring foot and jars (jarros). Plate rims recovered from the Spanish Governor's Palace in San Antonio are thin $(3 \mathrm{~mm})$ and rounded. Forms recovered from sites in Florida were plates as well (Deagan 1987). The small sample size of sherds available for study limits other inferences concerning vessel forms.

\section{Estimated Dates}

According to Deagan (1987:85), the estimated date of this type is from the late 1680s to the early 1700 s, but other accounts indicate that the ware may have been popular as early as 1598 and as late as 1725 (Cohen-Williams and Williams 2004:34). Here we suggest a date range of 1700 to 1725 (Figure 4-1).

\section{Place of Manufacture}

Castillo Polychrome may have been manufactured in Puebla, Mexico (Goggin 1968:185).

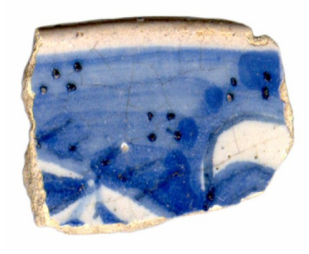

a

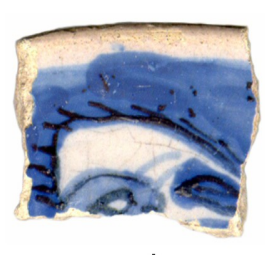

b

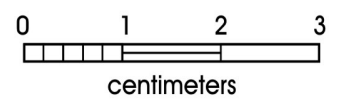

Figure 4-15. Castillo Polychrome. 41BX179: $a, b$. 


\section{SAN LUÍS POLYCHROME}

\section{General Description}

Designs on this ceramic type are floral sprays in green and brown on a cream background. Designs are geometrically arranged into sections divided by thin brown lines (Figure 4-16), one section on the basal interior and another along the rim. The paste is pinkish tan in color, although some fragments have a cream paste. This type is found only on relatively early Texas sites, such as Presidio Loreto (41VT8). Its presence at Mission Concepción (41BX12) is part of the evidence that the site was originally used as the first site of Mission San José y San Miguel de Aguayo (41BX3). The type was defined by Goggin (1968:166-169) and in Florida it is common on late seventeenth and early eighteenth century sites (Deagan 1987:75-77). It does not occur in California Spanish Colonial components.

\section{Vessel Forms}

Vessel forms include small and larger deep-brimmed plates and small bowls with out-flaring rims. All forms have a ring foot. In general, the sherds of this type are thicker than those of other Mexican-made tin-glazed ceramics (Goggin 1968:167). Body sherds can be as thick as $11 \mathrm{~mm}$ near the base. Near the rim, they thin to about $5 \mathrm{~mm}$.

\section{Estimated Dates}

San Luis Polychrome does not appear before 1650, indicating that is was manufactured during the last half of the seventeenth century and early eighteenth century, or about 1660 to around 1720 (see Figure 4$1)$.

\section{Place of Manufacture}

According to Lister and Lister (1976b:126), this was an early product of the Mexico City industry. Since green ceramics were considered lower quality and green was not suitable for finer types, this may have been considered a lower-class ware (Lister and Lister 1974:33; Seifert 1977:13). 


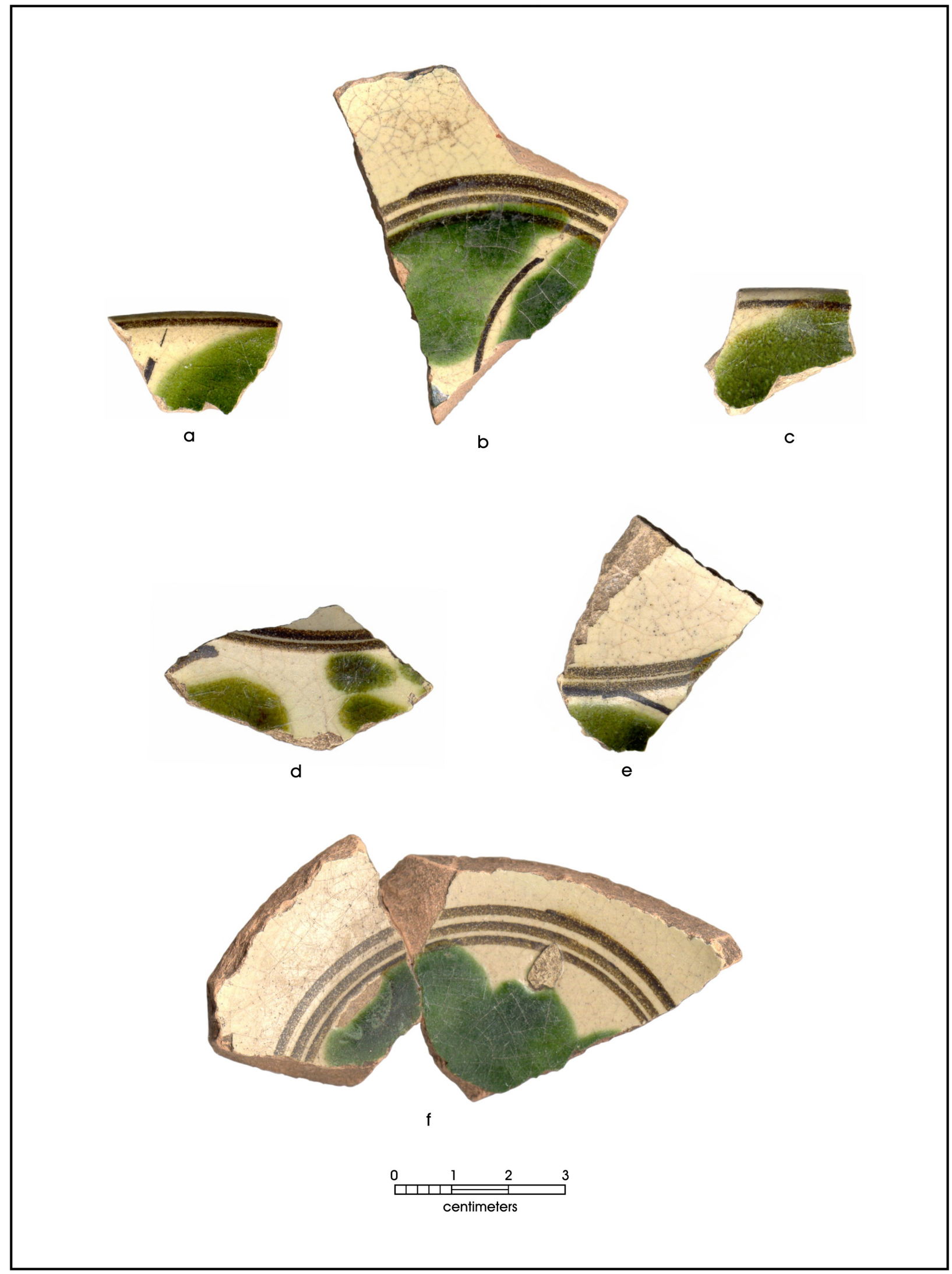

Figure 4-16. San Luis Polychrome. 41BX12: a; 41VT8: b-f. 


\section{ABÓ POLYCHROME TYPE A}

This type was first described and illustrated by Goggin (1968:169-173). Often, Aranama Polychrome is mistaken for Abó Polychrome due to similar color schemes and incomplete designs on small sherds recovered from sites in Texas (Figure 4-17). There are two main differences between the Abó and Aranama varieties. One is that Abó uses blue more freely in its decoration than Aranama (Figure 4-17c). The second is that Abó displays a greater amount of white background than Aranama Polychrome. Abó Polychrome predates Aranama Polychrome by as much as 50 years (Deagan 1987:79-81, 87). Florida classifications lump the type into a general Abó Polychrome type (Deagan 1987:81, 87) while California classifications use the type designation but the illustrated specimens (Cohen-Williams and Williams 2004:38) are different from those in the Type A shown here.

\section{General Description}

Decoration consists of branches with leaves or flower petals in opaque yellow and orange and bright, transparent blue with green stems (Figure 4-17). The colored leaves and petals are outlined in thin brown or black lines. The paste is usually cream-colored, although Goggin (1968:196) notes that it can range to terracotta.

\section{Vessel Forms}

Vessel forms encountered included small-brimmed plates (platos), small cups (tazas, pocillos), and bowls (escudillas). The rims of theses vessels are simple and rounded.

\section{Estimated Dates}

This type begins somewhat earlier than Puebla Polychrome, possibly 1640s, and tends to disappear by about 1700 (Goggin 1968:1272). Deagan (1987:81) argues that the ware may have been produced as late as 1750 . Here, we suggest a date range of 1650 to 1720 (see Figure 4-1).

\section{Place of Manufacture}

Abó Polychrome appears to be another type originating out of Puebla, Mexico. 


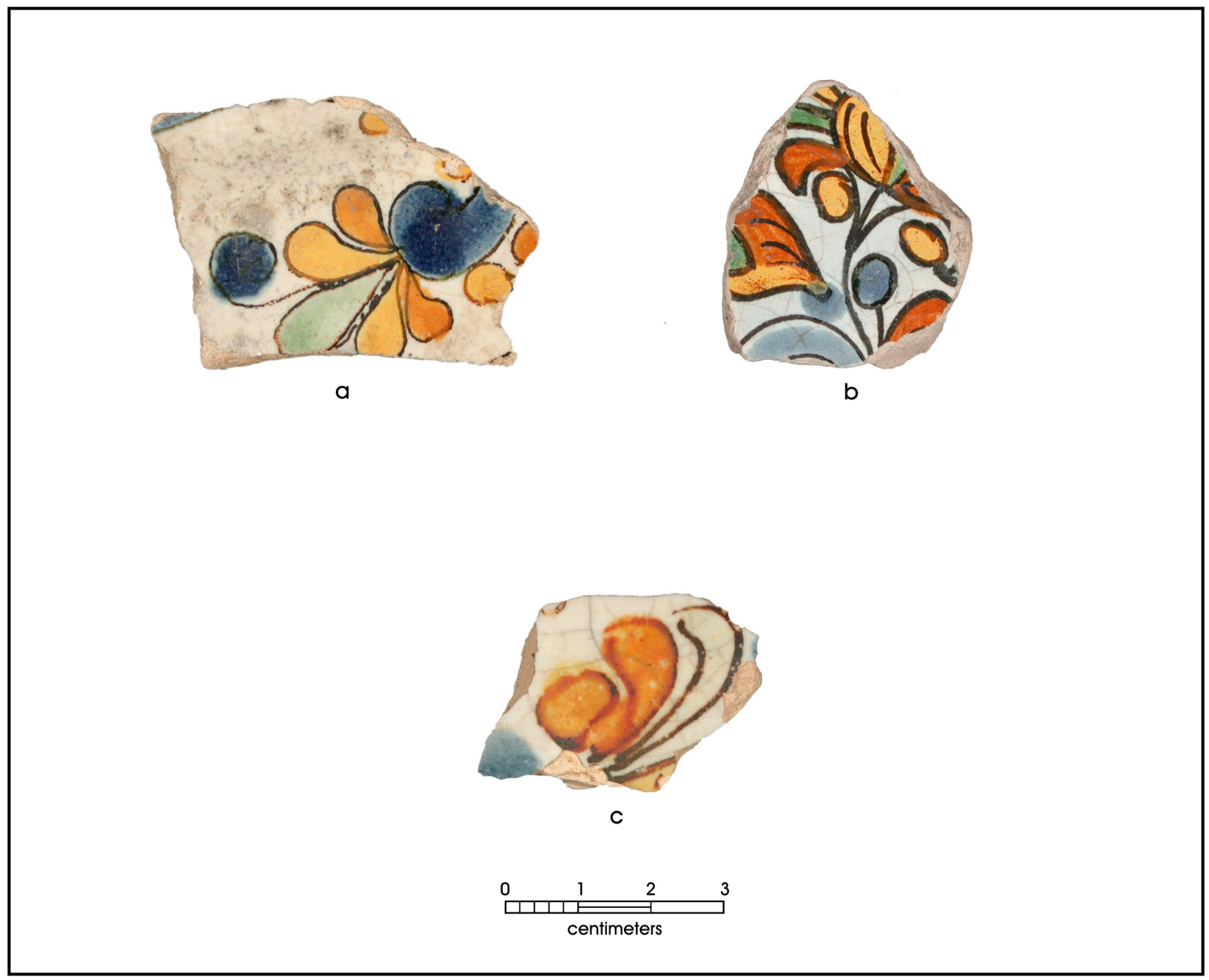

Figure 4-17. Abó Polychrome, Type A. (a-c) Courtesy of the Florida Museum of Natural History. 


\section{Puebla Polychrome}

Puebla Polychrome has been recovered from Mission San Antonio de Valero (41BX6) and several sites within Villa de Bexar, including San Fernando Cathedral (41BX7) and Presidio de Bexar (41BX179). Like San Luis Polychrome, this type is located at early Spanish Colonial sites in Texas. The type was originally defined by Goggin (1968:173-182). It has been identified in Florida collections from sites dating to the late $17^{\text {th }}$ and early $18^{\text {th }}$ centuries (Deagan 1987:81-82). The Puebla Polychrome type identified in California appears to be a latter form with different design elements than those documented in Florida and Texas (see Cohen-Williams and Williams 2004:27-36). The Lacy Puebla Polychrome variety of the Puebla Polychrome documented in California appears to share some design elements, however, with the specimens shown here (Cohen-Williams and Williams 2004:27-28).

\section{General Description}

There is no decoration on the exterior of plates and the interior of cups and bowls. The decorated surface is painted in blue swaths surrounded by lace or cobweb effects in thin black lines, with occasional black dots (Figure 4-18). It may also have touches of green, yellow, or orange. Design towards the rims of the vessels appears as cross-hatched combs in black. The design in the basal interior is often divided into quarters by double black lines. Makers' marks may sometimes be found on the basal exterior. The paste is usually cream to light buff in color, although they can be found in peach to terracotta shades on rare occasions.

Puebla Polychrome is thought to be an extension of the Talavera styles brought to the New World, which also exhibit the same lace or cobweb motifs (Lister and Lister 1987:238-239). The quality of the decoration on the wares can range from haphazard to very fine, and would have determined the value of the vessel at the time.

\section{Vessel Forms}

Vessel forms of Puebla Polychrome include deep plates (platos), small cups with no handles (tazas, pocillos), and bowls. All forms have a ring foot. Sherds are $5 \mathrm{~mm}$ or slightly less in thickness.

\section{Estimated Dates}

Puebla Polychrome appears during the last half of the seventeenth century to the 1720 s. In Texas, it is encountered only in the earlier Spanish sites. We suggest a probable date range of 1650 to 1725 (Figure 4-1). 


\section{Place of Manufacture}

Puebla Polychrome was produced in Puebla, Mexico.

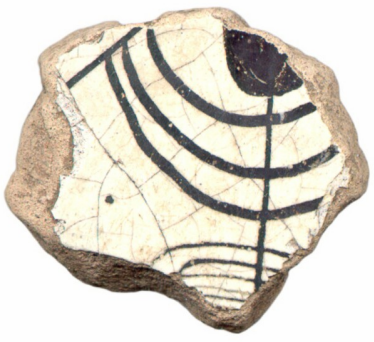

a

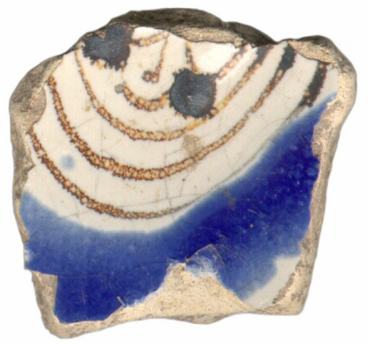

b

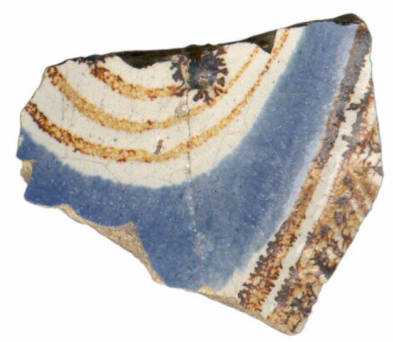

C

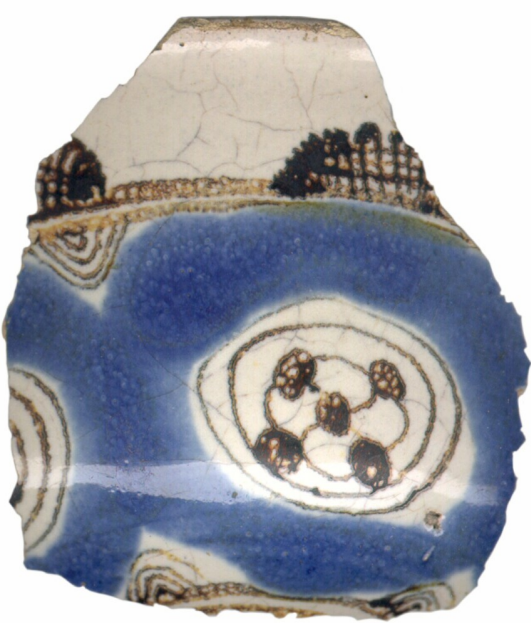

d

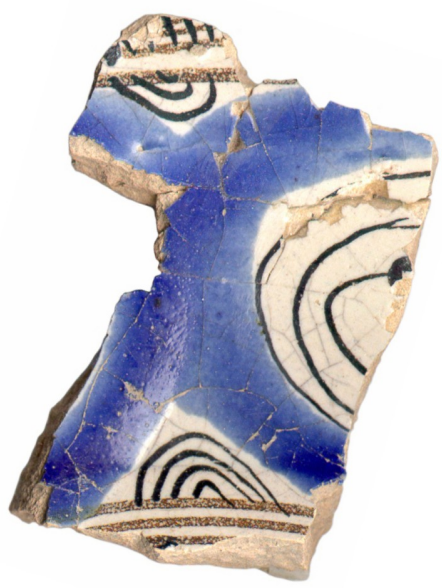

e

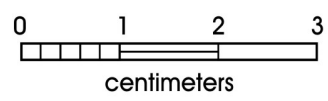

Figure 4-18. Puebla Polychrome. 41BX6: a-e. 


\title{
Eighteenth CENTURY
}

\author{
PUEBLA PLAIN
}

Puebla Plain is commonly found at all Spanish Colonial sites in Texas. When examining a ceramic assemblage, Puebla Plain usually comprises the largest portion of recovered majolicas from the sites. It is part of the Puebla majolica wares of the $17^{\text {th }}$ and $18^{\text {th }}$ century identified in Florida (Deagan 1987:77-78) and is identified as Puebla White in California classifications (Cohen-Williams and Williams 2004:1112).

\section{General Description}

Puebla Plain specimens are undecorated, white majolicas (Figure 4-19). Sherds from these undecorated wares are generally thin and light in weight. However, it is possible that the many of the sherds with no sign of decoration could also be pieces of otherwise decorated vessels such as Puebla Blue on White, Huejotzingo, or even Guanajuato. Small fragments of plain sherds from otherwise decorated vessels are categorized as Puebla Plain due to the lack of any tale-tell marks, limiting the utility of this type. The color of the glaze is commonly a creamy white, but some specimens exhibit a blue or greenish tint which may be the result of impurities in the glaze. Paste colors vary dramatically from cream to light orange. Puebla Plain sherds often exhibit degrees of crazing (see glossary in Appendix A), from minimal to abundant.

\section{Vessel Forms}

Vessel forms typical of Puebla Plain include small bowls, cups, and chamber pots (Lister and Lister 1974: Figure 8).

\section{Estimated Dates}

This type was popular throughout the eighteenth century and into the mid-nineteenth century (Lister and Lister 1974:30). Here we suggest dates of 1700 to 1850 (Figure 4-1).

\section{Place of Manufacture}

The production of Puebla Plain most likely occurred in Mexico, although the exact location is unknown. 


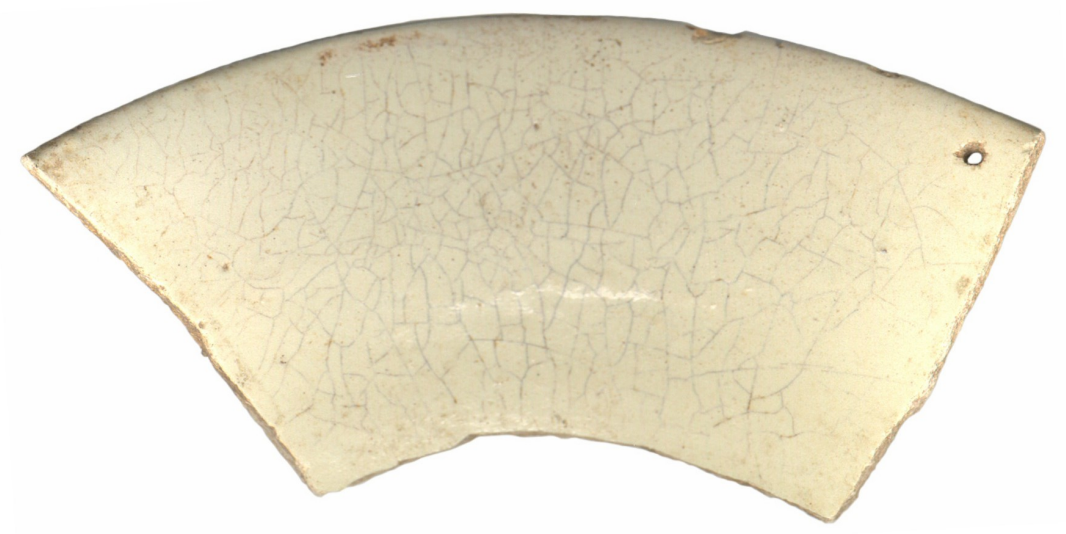

a

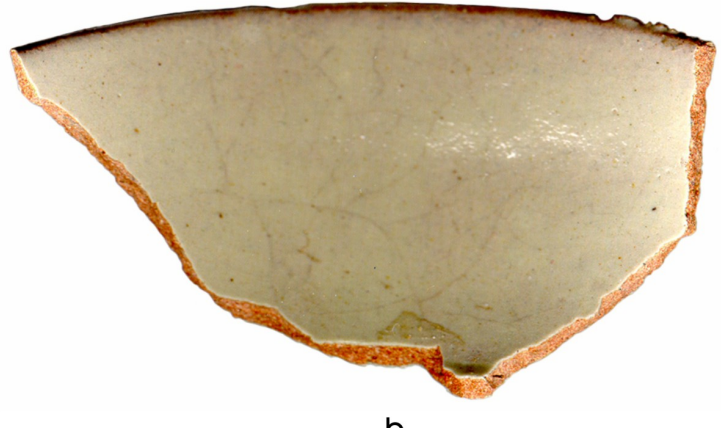

b

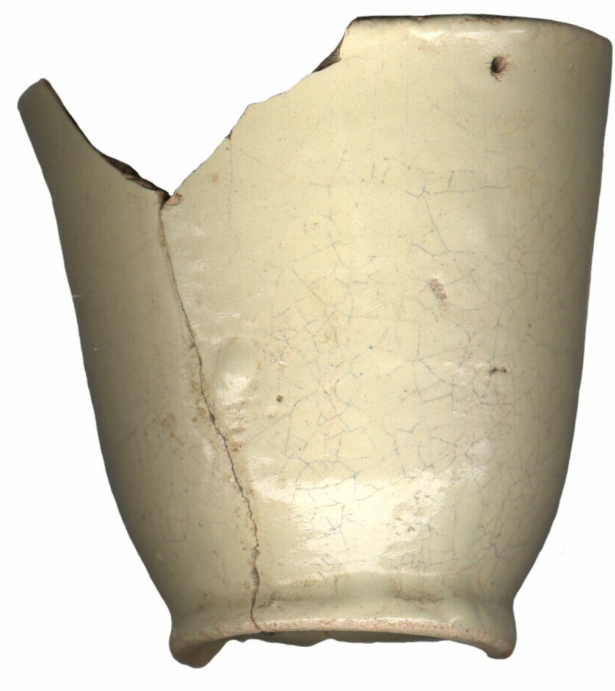

c

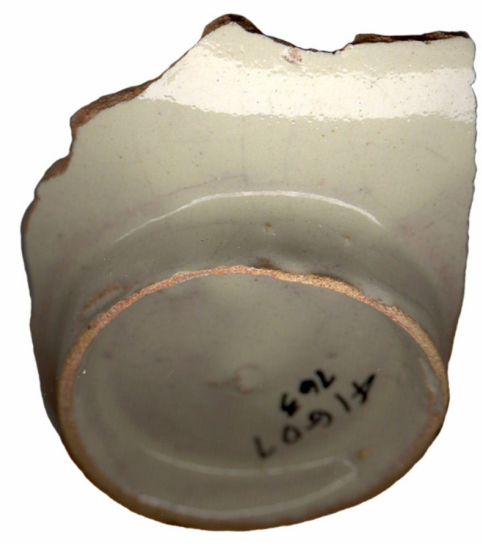

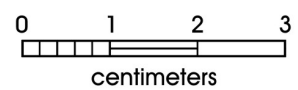

Figure 4-19. Puebla Plain. 41GD7: a-c. 


\section{ABÓ POLYCHROME TYPE B}

In Texas the type has been encountered in collections from the second site of Mission Espiritu Santo (1722 to 1752) north of Victoria, Texas (Lakeman 2001:75-76). The Abó Polychrome B is identical to Abó Polychrome Type B identified by Smith (1965:86) from Santa Rosa, Pensacola, in Florida. A type called Mount Royal Polychrome by Goggin (1968:159-161), dated to about the same time, may also be this type, though the past appears to differ. The Florida classifications identify the type as a variant of the Abó Polychrome type (Deagan 1987:80). The California classification system lumps the Abó and Aranama types into one, but the illustrated specimens are too small to determine whether the several varieties of Abó/Aranama Polychrome include the Abó Polychrome B type (Cohen-Williams and Williams 2004:38-57).

\section{General Description}

This type has the familiar orange rim band bordered with brown lines of Abó Polychrome (Figure 4-20). Suspended below the rim band are groups of blue petals; sometimes the paint is so thick it appears raised. A blue floral design in the center is surrounded by a similar band at the cavetto. The specimens recovered by Smith (1965:91-93) from Santa Rosa, Pensacola, Florida (1723-1752), have human, animal or floral central designs.

\section{Vessel Forms}

Typical vessel forms of Abó Polychrome B appear to be deep plates.

\section{Estimated Dates}

The popularity of this type in Texas is estimated at circa 1720-1750 (Smith 1965:86). Deagan (1987:81) indicates that Abó Polychrome B was produced only during the eighteenth century (see Figure 4-1).

\section{Place of Manufacture}

The exact location of manufacture is unknown, although it was possibly produced in Puebla, Mexico. 


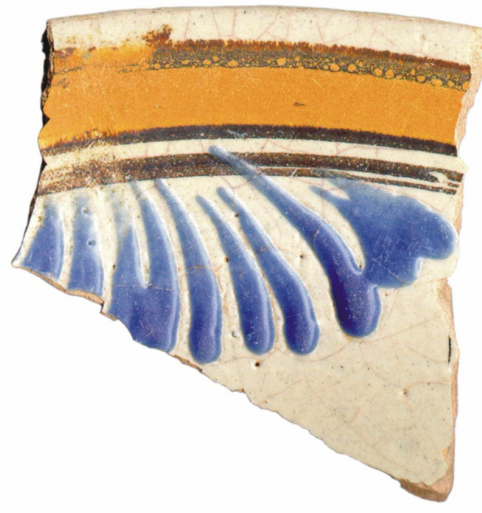

a

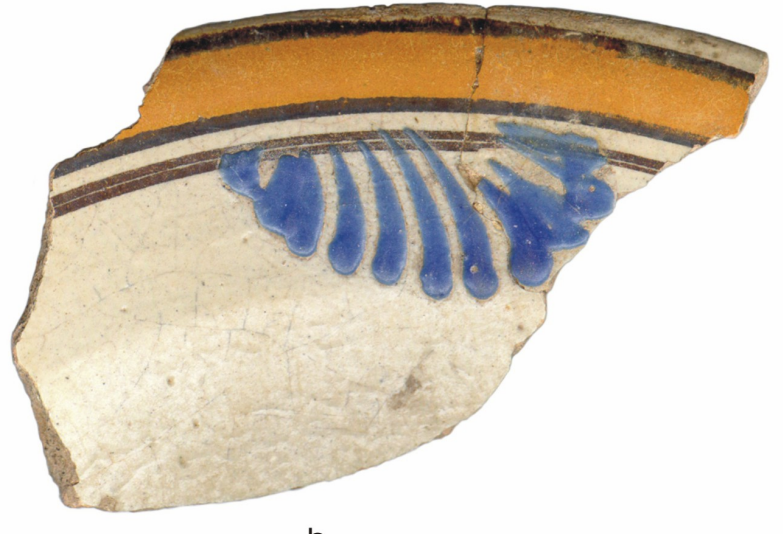

b

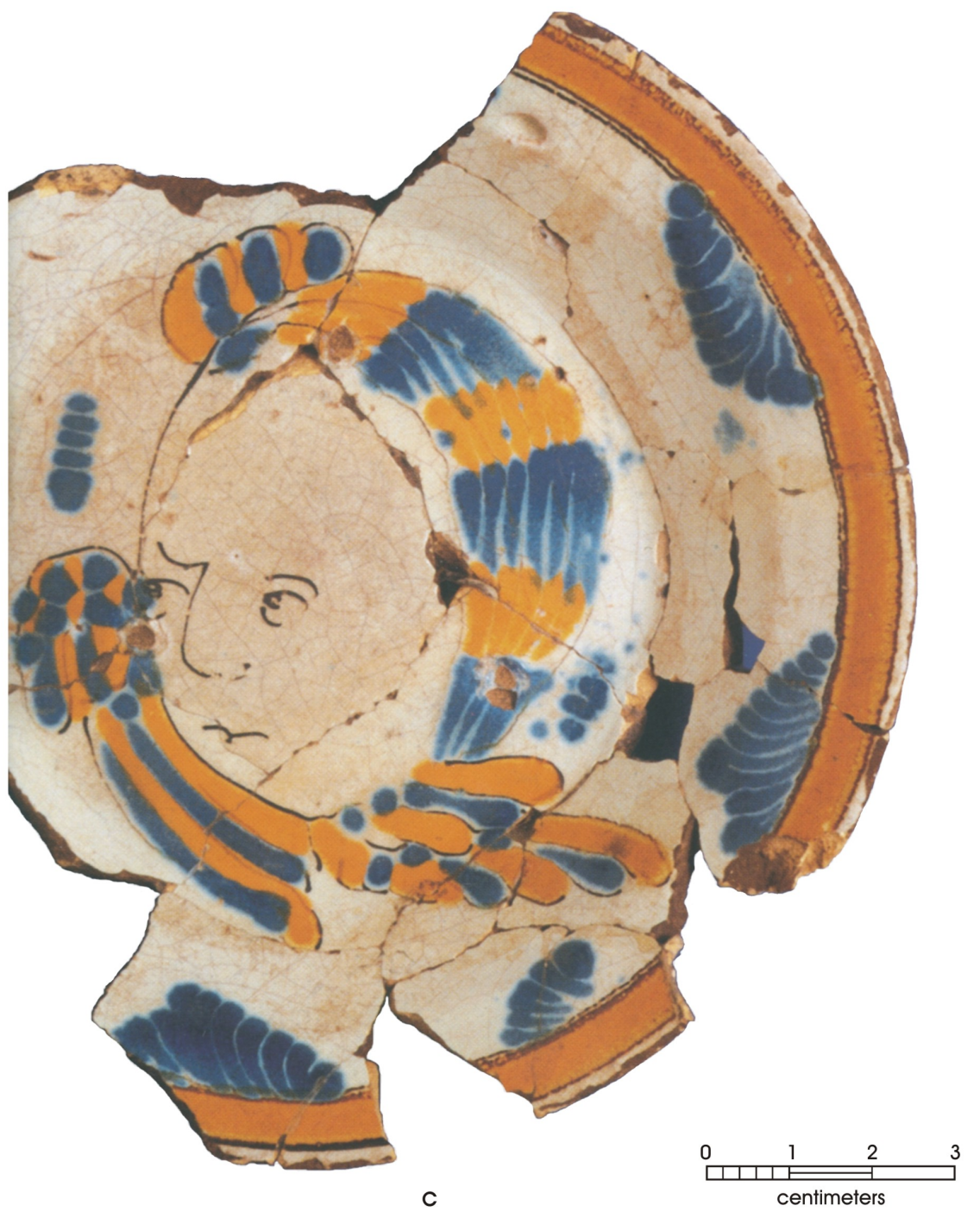

Figure 4-20. Abó Polychrome, Type B. 41GD7: a, b; c:Florida Museum of Natural History. 


\section{SAn Agustín Blue on White}

This type is part of the Puebla Blue on White Tradition. San Agustín is distinctive in its use of dark and light blue designs, the whiteness of the glaze, and design motifs used. Examples of San Agustín have been recovered from Presidios Loreto and La Bahía, Mission Espíritu Santo, Mission Rosario in Goliad, and the San Antonio missions. This type is present in Florida (Deagan 1987:82-83) and is classified as a variety of Puebla Blue on White in California (Cohen-Williams and Williams 2004:8, 23-25).

\section{General Description}

The surface of this type is completely covered with smooth, thick, chalky white enamel. Decoration is done in two or more shades of blue, with the darker shade more prominent (Figure 4-21). On earlier versions, conventional floral designs cover the rim and extend down to surround a central motif, which is occasionally a human figure. Spaces are sometimes filled with light blue hatching, dark blue dots, or intermingled dark and light blue dots. Designs completely cover the inside of plates. Light blue overlapping loops cover the underside of the ledge and rim. On later eighteenth-century versions, the plates are completely covered with blue flowers intermingled with lighter blue stems and the cups and bowls have blue bands on the interior. The paste is usually cream to light buff in color. Sherds recovered in Texas tend to be 5 to $6 \mathrm{~mm}$ in thickness, with paste color being pinkish cream to cream in color.

\section{Vessel Forms}

Vessel forms common to San Agustín include deep, brimmed plates (platos), bowls (soperos, escudillas), and small cups (tazas, pocillos).

\section{Estimated Dates}

This type was first described as dating from about 1700 to 1730 (Goggin 1968:187-189). Smith (1965:84) suggested extending this date to 1750 on the basis of its popularity at Santa Rosa Pensacola, which dates from 1722 to 1752 . This might also explain its presence at the Goliad site of Presidio La Bahía, which was moved there in 1749. May (Barnes and May 1972:31) suggests this type dates to 1700 to 1780 on the basis of the later California mission sites, and we follow that temporal estimate here (see Figure 4-1). Seifert (1977:187) suggests that the post-1730 version be called Chinoiserie Blue on White. Further study may allow dividing this type into two, depending on the dates of other ceramic types from the same sites.

\section{Place of Manufacture}

San Agustín is of the same tradition of ceramics produced in Puebla, Mexico. 


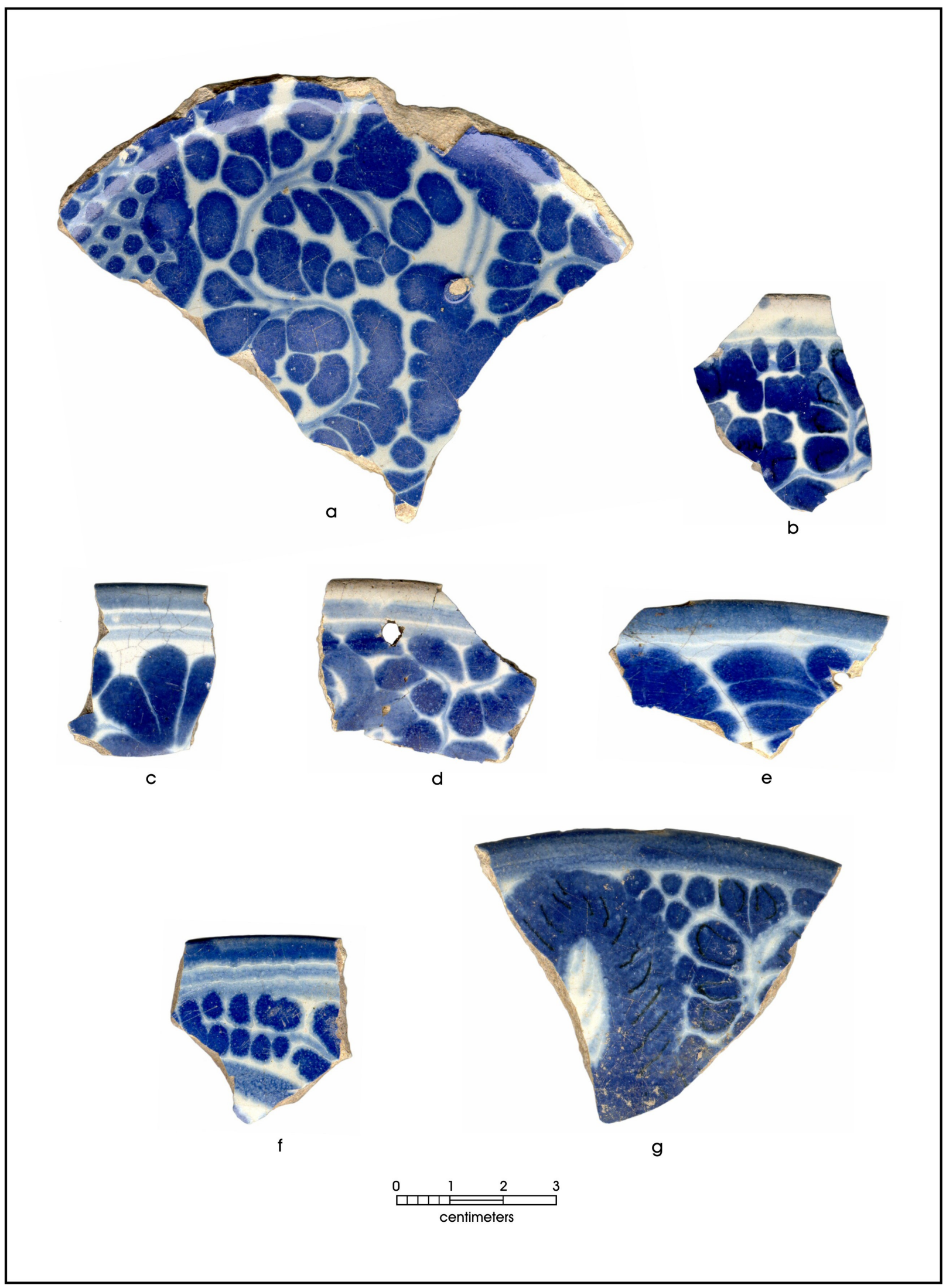

Figure 4-21. San Agustín Blue on White: 41GD7: a-c, e-g; 41VT8: d. 


\section{Puebla Blue on White}

This ceramic type is the most widespread of the Puebla Blue on White Tradition majolicas (Deagan 1987:83). It was first described and dated by John Goggin (1968:190-195). He included nearly every type of tin-glazed ceramic decorated in blue and white. Recent research has begun to tease out some of these into individual types. Puebla Blue on White is commonly found at most Spanish Colonial Texas sites such as the San Antonio missions, Mission Espíritu Santo, Mission Rosario, Mission Refugio, Presidio Loreto, and Presidio La Bahía. The type is found throughout Florida (Deagan 1987:83-84) and California (Cohen-Williams and Williams 2004:8, 12-18).

\section{General Description}

This pottery type is covered on the interior and exterior with white enamel and decorated with designs painted in dark and light blue on the inside of plates and bowls and the outside of cups (Figure 4-22). The major plate design has two blue bands below the rim from which are suspended groups of single blue petals alternating with single blue flowers. Other design elements include dots, lines, and lobes. The central design of this type is usually a crane form or various floral arrangements. Puebla Blue on White has been said to have been influenced by Chinese, Talaveran, and Sevillian ceramic models (Lister and Lister 1974:29-31). The paste is usually cream in color. Sherds vary from 4 to $6 \mathrm{~mm}$ in thickness on the same vessel.

\section{Vessel Forms}

Vessel forms commonly encountered include deep, brimmed plates (platos), small cups (tazas, pocillos), and bowls (soperos) with everted rims. Other forms common to Puebla Blue on White consist of jars (jarros), vases, inkwells, figurines, basins of various types, and tile.

\section{Estimated Dates}

The manufacture of Puebla Blue on White occurred throughout the eighteenth century. Ivey (Ivey and Fox 1999:42) suggests 1720s to 1760s in San Antonio. In Figure 4-1 we assign manufacturing of the ware to an interval between 1650 and 1830 (see also Gerald 1968:43; Deagan 1987:84; Lister and Lister 1987:346), with suggestions of the actual range differing depending on the source of information. This long date range may also be a result of the inclusion of Blue on White varieties that were later separated into different types. Bowls with everted rims (soperos) have only been found at the first site of Presidio La Bahía (Gilmore 1973:40) that was in existence from 1720 to 1724, and Presidio Los Adaes in Louisiana (Gregory 1980: Plate 5j), but no other sites in Texas. 


\section{Place of Manufacture}

Puebla Blue on White was manufactured at Puebla and perhaps elsewhere in Mexico. By 1700, blue decoration on white backgrounds was identified with Puebla, but later it apparently was also made in other towns including Mexico City. However, small Blue on White bowls with abstract floral designs in the basal area and everted rims decorated with blue dashes made in Mexico City (Lister and Lister 1974: Figure 10c; Seifert 1977:16) have been included here in the Blue on White category.

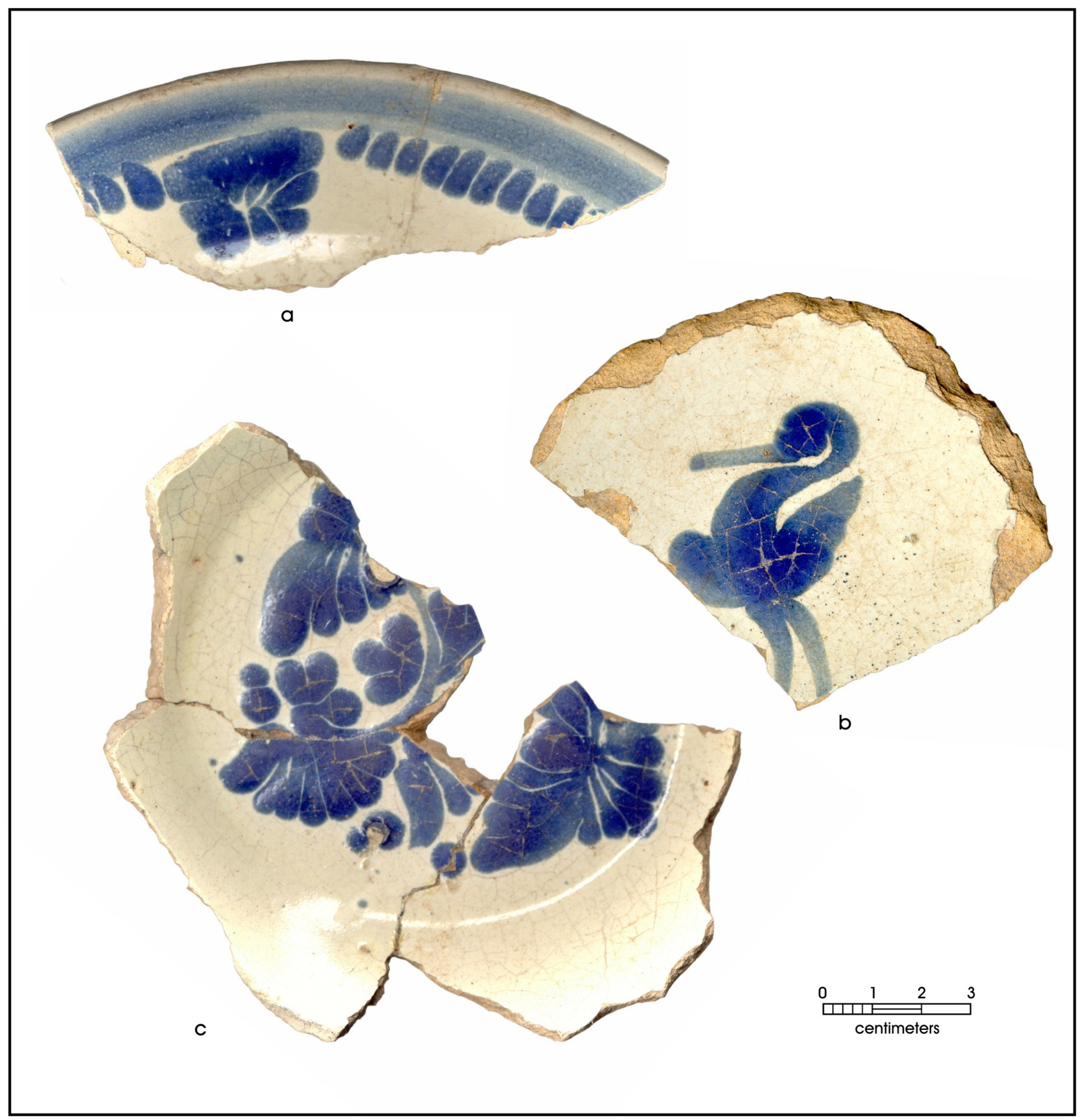

Figure 4-22. Puebla Blue on White. 41BX12: a. 41BX3: b. 41GD7:c. 


\section{HUEJOTZINGO BLUE ON WHITE}

Goggin (1968:196) suggests that this type is a variant of Puebla Blue on White. The name is derived from the town of Huejotzingo in Puebla, Mexico. The type is not useful for dating, since it was made throughout the 18th century and perhaps even after 1850. The lack of more complex decoration may indicate that this is a cheaper ceramic type. Huejotzingo Blue on White has been recovered at many of the Texas Spanish Colonial sites in operation after 1700, including Presidio La Bahía, Mission Espíritu Santo, Mission Rosario, Mission Refugio, La Villa de la Bahía, and the San Antonio missions. In California, the type is classified as a variety of Puebla Blue on White while vessels with a single green band are identified as the Huejotzingo Green on White variety of the Puebla Green on White (CohenWilliams and Williams 2004:8, 18-20, 58-59). The Huejotzingo Blue on White type also is common in Florida (Deagan 1987:83).

\section{General Description}

The paste and surface finish are similar to those of Puebla Blue on White. The glaze color is usually a creamy white. Decoration consists of a single blue band around and slightly over the rim (Figure 4-23). The blue can vary from dark blue to pale gray-blue. Occasionally, examples of Huejotzingo have been recovered exhibiting a green rim band (Figure 4-23d), though some believe that the green version was produced at a later date than the blue. The band is located on the inside rim of plates and the outside rim of cups. Since such a large part of these vessels are undecorated, a large percentage of undecorated tinglazed sherds may be from this type of vessel. Sherds are generally $5 \mathrm{~mm}$ in thickness, and the paste is cream or pink in color.

\section{Vessel Forms}

Vessel forms of Huejotzingo are similar to plate and cup forms of Puebla Blue on White. Specimens recovered from Texas sites indicate that Huejotzingo was produced as plates (platos), brimmed bowls (soperos), cups (tazas, pocillos), and small bowls (escudillas).

\section{Estimated Dates}

This type was popular throughout the eighteenth and nineteenth centuries (Goggin 1968:195). The blue version of Huejotzingo began production circa 1700, whereas the green banded style is believed to have been substituted starting about 1780 (Barnes and May 1972:33-34; see also Figure 4-1). Some authorities have suggested that the Huejotzingo variety persists to this day (Gerald 1968; Barnes and May 1972:32). 


\section{Place of Manufacture}

The manufacturing of Huejotzingo occurred in Puebla, Mexico, and possibly other Mexican pottery centers.

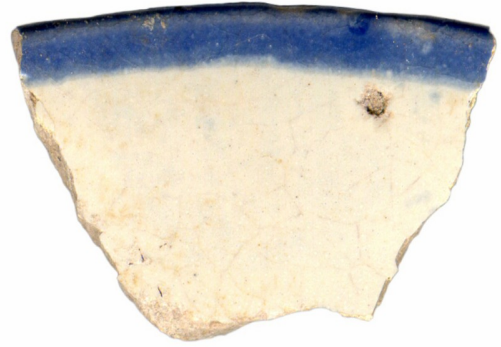

a

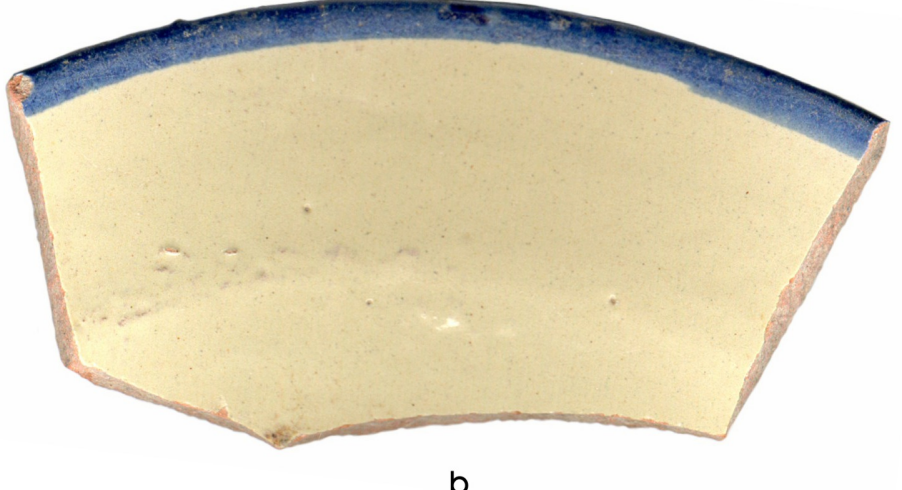

b

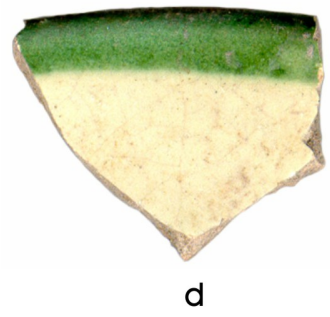

0

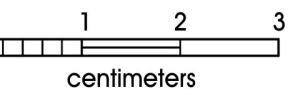

Figure 4-23. Huejotzingo Blue on White. 41GD7: a-d. 


\title{
LATE Eighteenth Century
}

\author{
MOLDEd BLUE ON WHITE
}

Molded Blue on White majolicas resembles San Agustín Blue on White at first glance, but three major characteristics differentiate it from the previously discussed types. First, Molded Blue on White does not exhibit black accents. Second, San Agustín exhibits much less white background. Third, the rims of Molded Blue on White are molded into scalloped shapes rather than the uniform rim seen in San Agustín wares. The type has been identified in the Presidio La Bahía collection and in collections from Mission San Juan Capistrano and Mission San José, both in San Antonio. The Florida classifications make no distinctions between Puebla Blue on White and this design, although it is possible that they have encountered few examples (Deagan 1987:85). The California classifications seem to identify the ware as part of San Agustín Blue on White (Cohen-Williams and Williams 2004:25).

\section{General Description}

This type has two shades of blue floral designs on white (Figure 4-24). Vessels are molded with a flat base (no ring foot) and scalloped rims. Several different designs have been described by Gilmore (1974:51 and Plates 10 and 11) and identified in collections from Presidio La Bahía, Mission San Juan Capistrano, and Mission San José. The sherds vary from tan to pinkish tan beneath the glaze, and their thickness varies from $5 \mathrm{~mm}$ at the base to $4 \mathrm{~mm}$ at the rim.

\section{Vessel Forms}

One plate segment was found at Mission Rosario near Goliad, Texas. The other sherds recovered in Texas appear to be fragments of plates and cups.

\section{Estimated Dates}

The estimated dates of production are the latter part of the eighteenth century, probably between 1775 and 1800 (see Figure 4-1).

\section{Place of Manufacture}

The Molded Blue on White was produced in Mexico, although the exact location is unknown. 


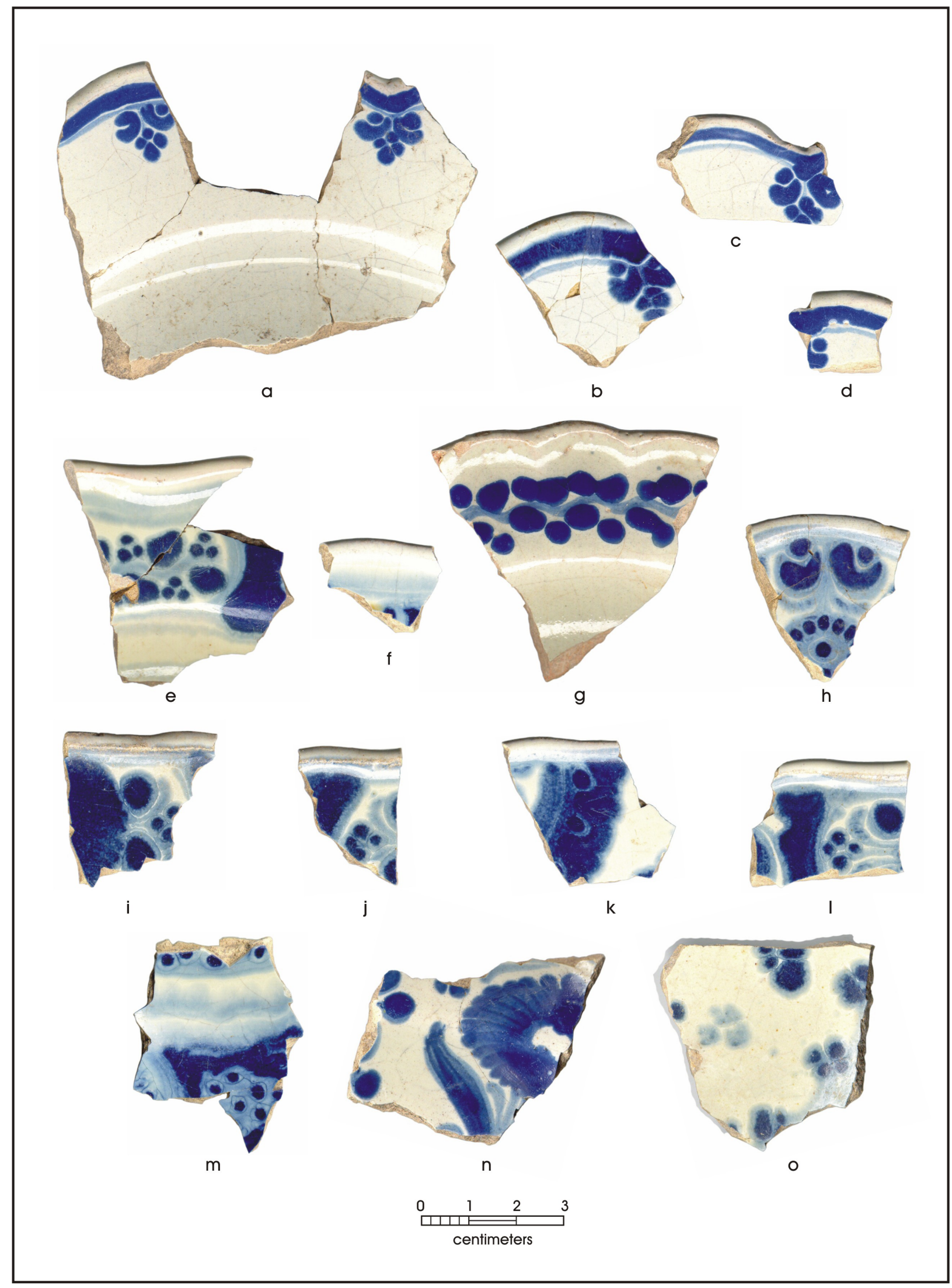

Figure 4-24. Molded Blue on White. 41BX12: a; 41GD7: b, d, e, g, i-l, o; 41BX3: c; 41BX5: f, m, n. 


\title{
LATE EIGHTEENTH CENTURY TO EARLY NINETEENTH CENTURY
}

\author{
THE ARANAMA POLYCHROME TRADITION
}

The first attempt to formally describe these ceramics with predominantly orange and green decoration was published in Goggin's Spanish Majolica in the New World (1968:196-198). This polychrome group succeeded eighteenth-century blue on white types. Many archaeologists working in Texas sites have confused Aranama types with the late-seventeenth-century Abó Polychrome type, partially because recovered sherds are generally too small to be accurately identified, and partially because there has been a mistaken tendency to push the dating of Abó Polychrome type into the early eighteenth century. Study of the majolica types found at the 1726 to 1749 site of Presidio La Bahía has convinced the senior author that the decoration of the polychrome sherds often does not accurately match Goggin's illustrations and description of Abó Polychrome (1968:169-173, Plates 12a-c). The fact that it has been considered to be associated with Puebla Polychrome and San Luis Polychrome (Goggin 1968:171) does not guarantee that Abó Polychrome continued as late into the eighteenth century as they did. A number of types have been described by Barnes and May (1972:30) as being part of an Aranama Polychrome Tradition. Before that time, publications on majolica were primarily based on excavations at pre-1800 sites. Barnes and May were able to recover majolicas from sites occupied through the first half of the nineteenth century in Arizona and California. Several of these Aranama types have now also been recognized from Texas sites (Fox 2002; Nickels 2000).

The named types that are part of the Aranama Tradition are described below. All other orange-banded polychromes are included here in the general Aranama Polychrome type until they can be split into separate types in the future.

\section{ARANAMA POLYCHROME}

This type was first described by Goggin (1968:196-198) and includes all the late eighteenth to midnineteenth century ceramics with an orange band and green coloration that have not been separated into any of the types listed below. Aranama Polychrome has been recovered from various sites in Texas including the San Antonio missions, Presidio Bexar, Mission Rosario, Mission Espíritu Santo, Mission San Agustín de Ahumada, San Saba, Presidio La Bahía, Mission San Lorenzo, and Mission Dolores de los Ais. The type is found in Florida (Deagan 1987:86-87) and is the same as the Abo Aranama Polychrome type identified in California (Cohen-Williams and Williams 2004:8, 38-41).

\section{General Description}

A yellow or orange band bordered by narrow brown/black lines is located below the lip of the vessel and sometimes frames a central geometric or floral design in the base (Figure 4-25b). Basal designs can also 
consist of human figures in colorful costumes (Goggin 1968: Plate 2), some of which have been recorded by archaeologists (Goggin 1968: Plate 21; Smith 1965:91). Central figures are sometimes surrounded by blue petal arrangements similar to those on Puebla Blue on White, or by orange, green, and brown balls surrounded by black lines and occasional blue dots (Figure 4-25a, b, d). Sherds have a pinkish tan to tan paste and vary from $5 \mathrm{~mm}$ at the center of the base to $4 \mathrm{~mm}$ near the rim.

\section{Vessel Forms}

Vessel forms common in the Aranama type are deep, brimmed plates (platos, soperos), small cups (tazas, pocillos), and bowls (escudillas).

\section{Estimated Dates}

It appears that the Aranama Polychrome was manufactured during the last half of the eighteenth century and the first half of the nineteenth century (Goggin 1968:198). We suggest a range of 1750 to 1850 (Barnes and May 1972:12, 34; see Figure 4-1).

\section{Place of Manufacture}

This type was most likely produced in Puebla, Mexico, but probably in other Mexican locations as well.

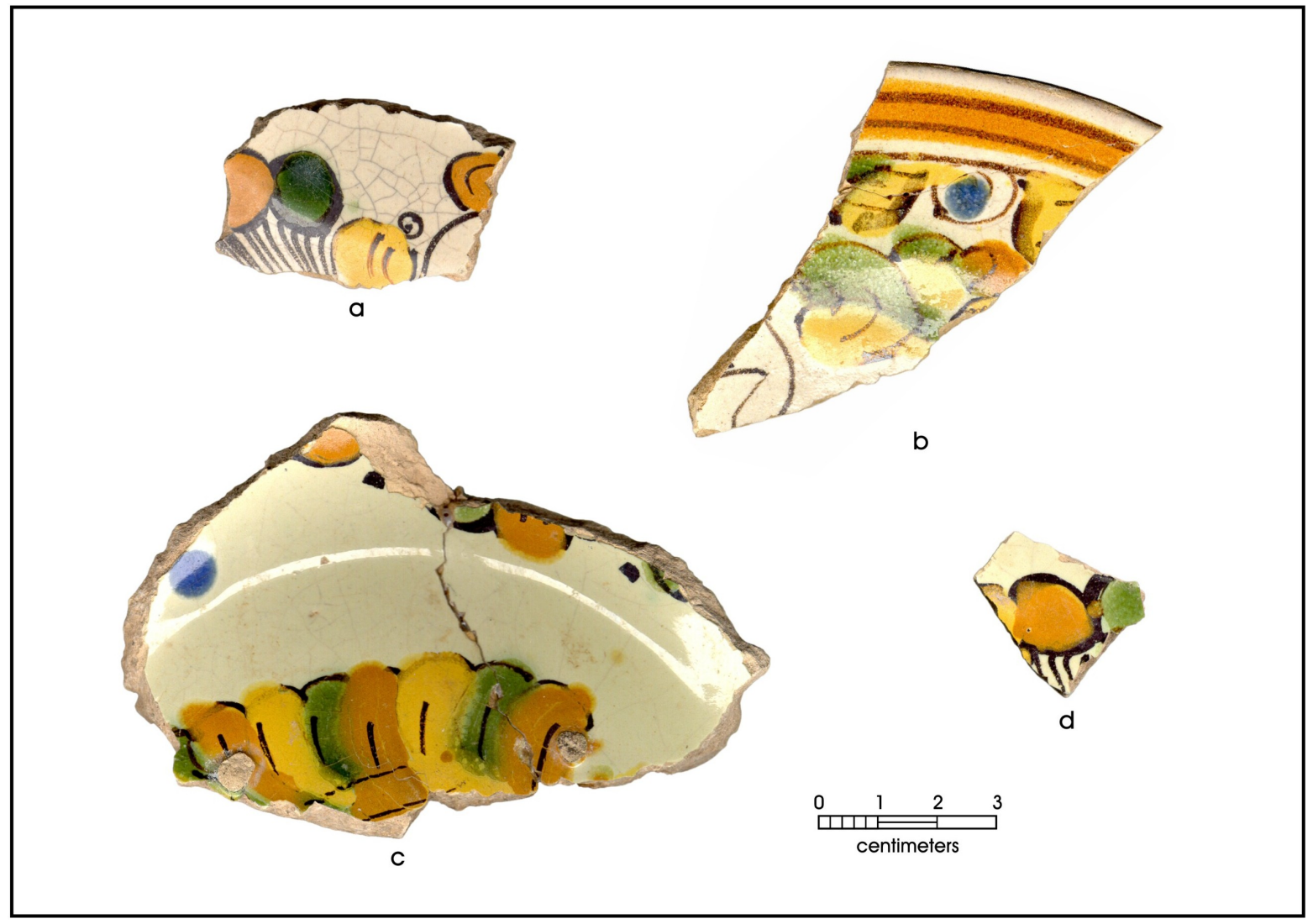

Figure 4-25. Aranama Polychrome. 41GD7: a-d. 


\section{SAN Diego POLYCHROME}

Barnes includes this in the Aranama type, whereas May separates it into a new type (Barnes and May 1972:36) within the Aranama Tradition. It shares the same color scheme as the rest of the Aranama Polychrome wares, but differs in its distinctive floral motif (Figure 4-26). San Diego Polychrome has been recovered from Spanish Colonial sites in Texas that were occupied between 1780 and 1825 including Presidio La Bahía, Mission Valero, Mission San Juan, and Mission Rosario. The type appears to be absent from Florida and in California it is classified as a variety of the Abó Aranama Polychrome (Cohen-Williams and Williams 2004:8, 46-48).

\section{General Description}

The glaze is a creamy white with little evidence of crazing. Beneath the typical Aranama orange band are yellow, green, and brown balls outlined in black and seemingly suspended from groups of black stems. Alternating with these are triangles, half yellow and half green, and small cobalt-blue dots (Figure 4-26). The floral motif is presented as black vines with yellow, orange and green flowers exhibiting green leaves. The colors appear more intense than Abó Polychrome and the other varieties of Aranama Polychrome. Anthropomorphic figures sometimes appear as the central design of the vessel. Sherds are usually 3 to $5 \mathrm{~mm}$ thick. The paste is cream to red in color.

\section{Vessel Forms}

Vessel forms recovered from Texas sites include deep brimmed plates (platos, soperos) and cups (tazas, pocillos).

\section{Estimated Dates}

The estimated dates of production for this type range from 1770 to 1800 (Barnes and May 1972:35; see also Figure 4-1).

\section{Place of Manufacture}

San Diego Polychrome, similar to the rest of the Aranama Polychrome tradition, was produced in Mexico, although the location is otherwise unknown. 


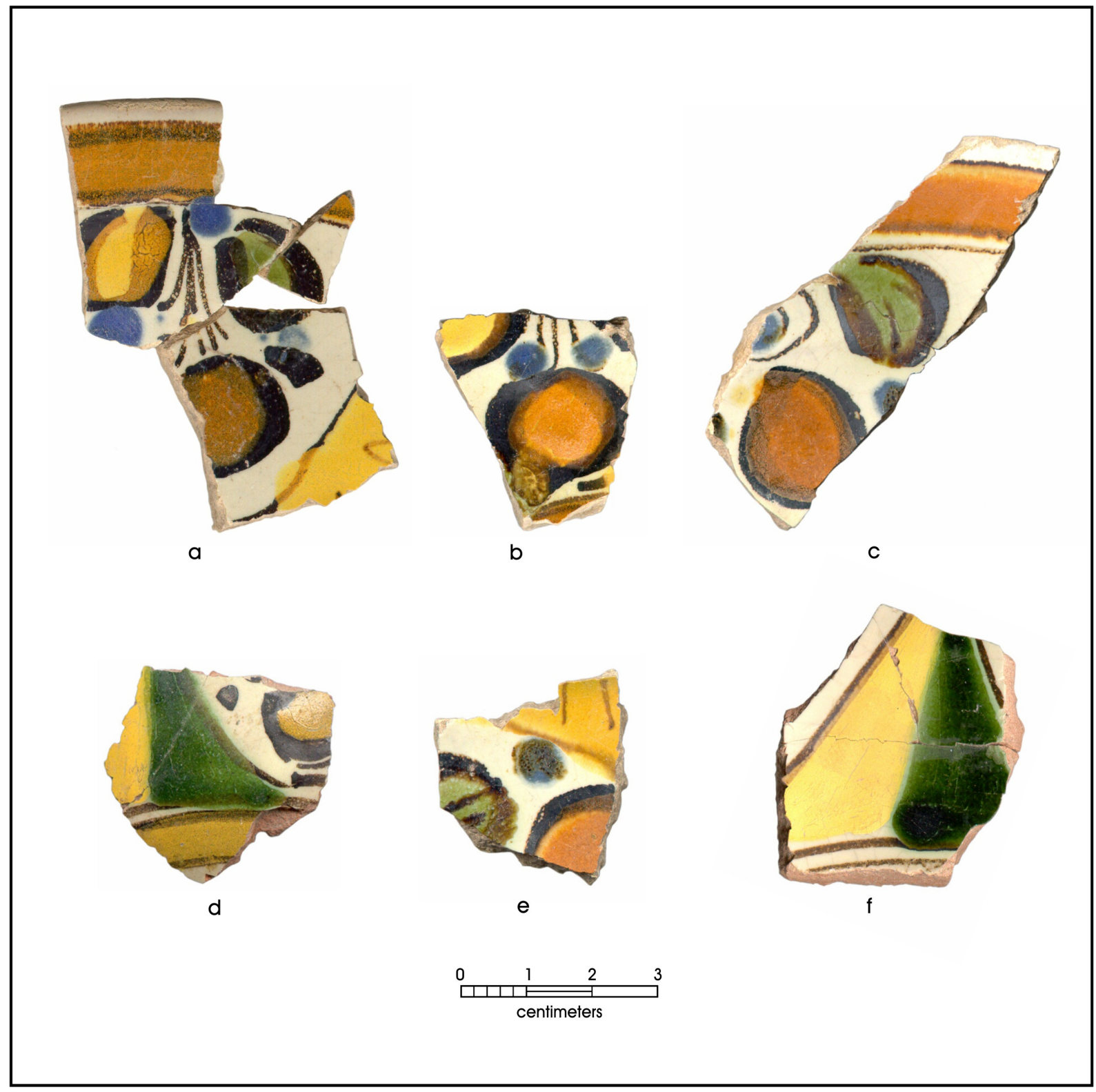

Figure 4-26. San Diego Polychrome. 41WN30: a; 41GD7: b, c, e; 41BX6: d; 41BX5: f. 


\section{MONTEREY POLYCHROME}

Barnes includes Monterey Polychrome within the Aranama Polychrome type, whereas May (Barnes and May 1972) separates it as Monterey Polychrome type. This type occurs at sites all over California, according to May, is also present in late $18^{\text {th }}$ and early $19^{\text {th }}$ century sites in Florida, and evidently was popular in Texas slightly earlier than in California. Monterey Polychrome has been recovered from Presidio La Bahía, Mission Espíritu Santo, Mission Rosario, Mission Refugio, Rancho de las Cabras, and the San Antonio missions. In California it is classified as a variety of the Abó Aranama Polychrome (Cohen-Williams and Williams 2004:8, 41-44). In Florida, the type is the same as the Nopaltapec Polychrome defined by Seifert (1977:237-240), although May (1975:36) refers to it as Monterey Polychrome.

\section{General Description}

Beneath the usual orange band are large yellow ovals with black diagonal slashes. On either side of the yellow ovals, orange spirals alternate with extended green fronds. Another orange band around the cavetto encloses a similar orange and yellow spiral with a row of blobs of the same green on either side (Figure 4-27a-b, g). This type of decorating has been compared to a stylized cornstalk surrounded by "baroque flourishes and elongated, light green floral sprays" (Cohen-Williams and Williams 2004:41). Sherds vary from 5 to $7 \mathrm{~mm}$ in thickness and the paste is pink to a yellowish cream in color.

\section{Vessel Forms}

Common vessel forms recovered from Texas sites include deep brimmed plates (platos, soperos) and cups (tazas, pocillos).

\section{Estimated Dates}

Monterey Polychrome appears in the archaeological record between 1800 and 1830 in California (Barnes and May 1972:36). In Florida, the ware is found in sites occupied between 1784 and 1821 (Deagan 1987:88). In Texas, the type probably began in the late 1700s since it has been found in deposits at Mission Espíritu Santo and Presidio La Bahía in the locations they occupied after 1749. It also appears at Rancho de las Cabras near Floresville, Texas, which was built during the 1750s (Ivey and Fox 1981:35). We suggest a date range of 1775 to 1830 (Figure 4-1).

\section{Place of Manufacture}

Monterey Polychrome was possibly produced in Puebla, Mexico. Others indicate that it may have been produced in Mexico City as well (Cohen-Williams and Williams 2004:43). 


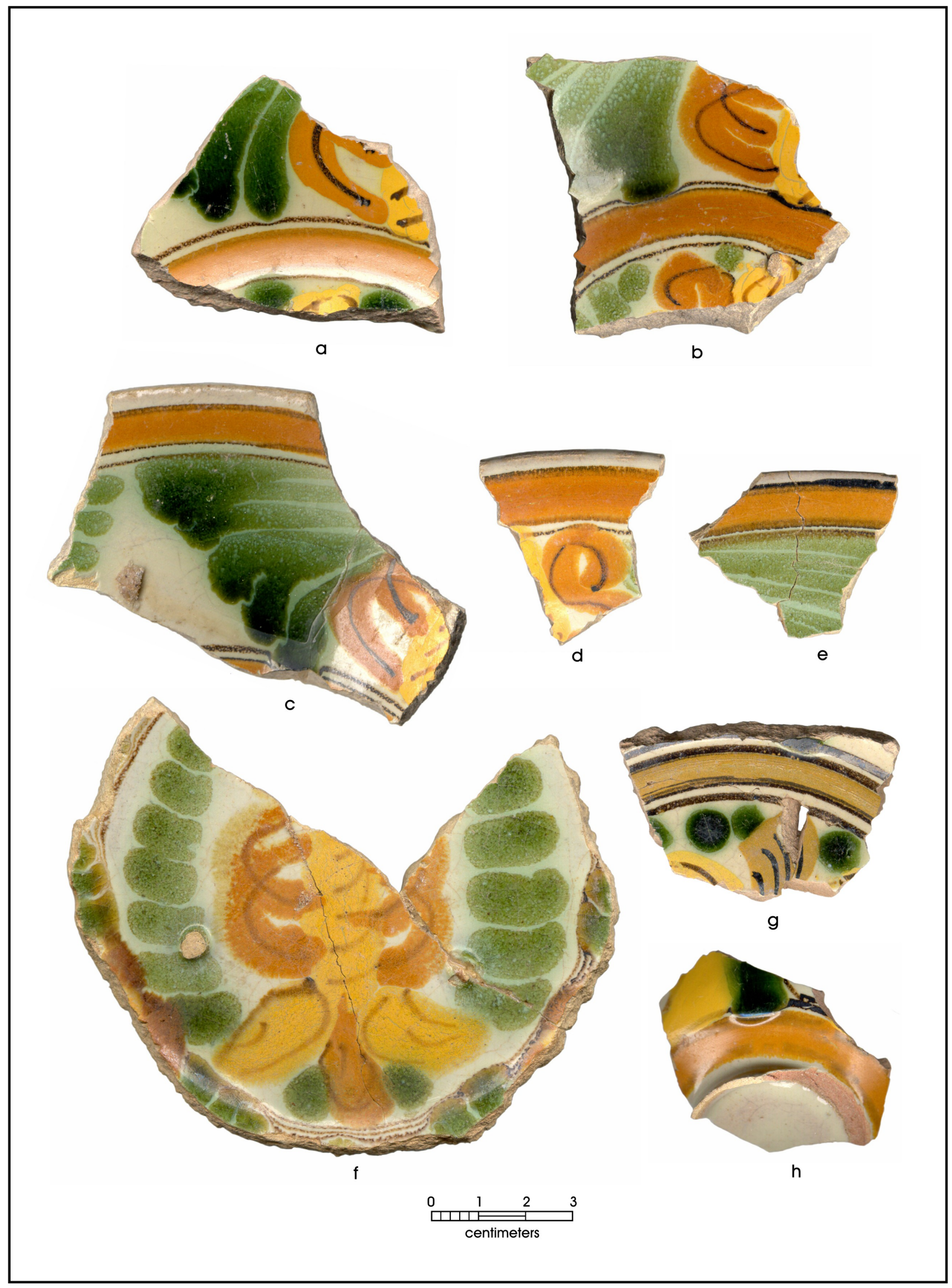

Figure 4-27. Monterey Polychrome. 41GD7: a-e; 41WN30; f; 41BX5: g-h. 


\section{LA BAHIA POLYCHROME}

Research by the senior author conducted on ceramics recovered at the last site of Presidio La Bahía (41GD7) suggests this type was significantly different from the previously described types included under the Aranama Polychrome Tradition. Here we considered it a distinct type. Its distribution appears to be limited to Texas.

\section{General Description}

This type has not been previously described by other authorities, nor has is been identified in any other region at this point. The decoration on this ware consists of blobs of yellow, orange, and green with dots and occasional slashes of blue covering the entire area between a brown-bordered, yellow-orange band below the rim and another around the cavetto (Figure 4-28). Very thin brown/black lines run up and down between the bands and are also used to accent the green and yellow blobs. The paste is pink. The entire design is much more delicate than that on the other Aranama types, and the color scheme does not appear as intense. No hint of the central design has so far been found.

\section{Vessel Forms}

The only form found so far is the usual deep plate with a ring foot. Sherds vary from 3 to $5 \mathrm{~mm}$ in thickness.

\section{Estimated Dates}

So far, this type has only been found on the site of Presidio La Bahía in Goliad, which would date it from the mid to the late $18^{\text {th }}$ century or slightly later. Here we suggest a date range of 1750 to 1820 (see Figure 4-1).

\section{Place of Manufacture}

The manufacture of the La Bahía Polychrome probably occurred in Puebla, Mexico, although it is possible it was produced in other areas of Mexico as well. 


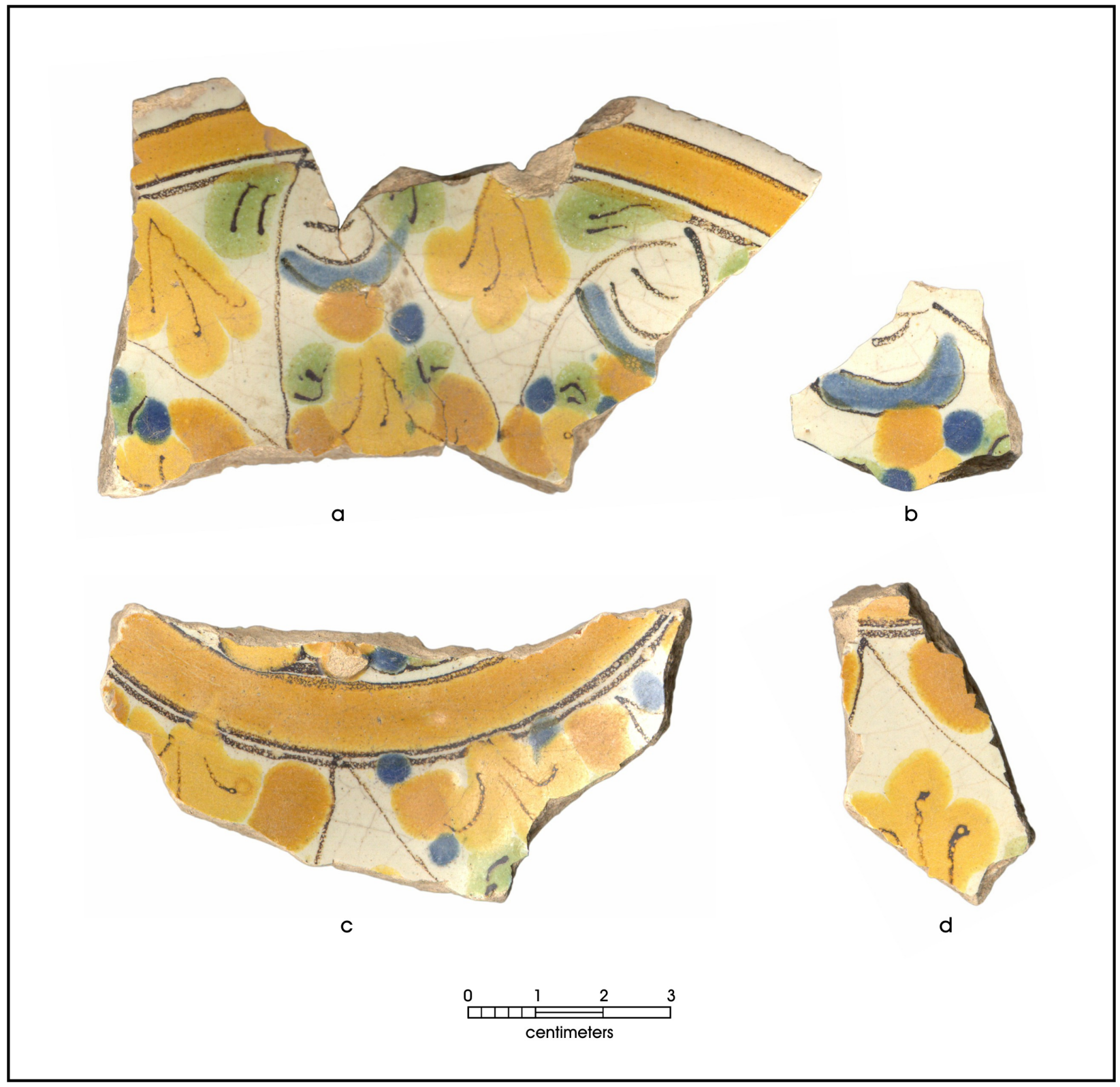

Figure 4-28. La Bahía Polychrome. 41GD7: a-d. 


\section{ORANGE BAND POLYCHROME}

This type has been called Orange Band Polychrome by Barnes (Barnes and May 1972:12-13) and Orangeline Polychrome by Gerald (1968:36). Archaeologists in Texas have chosen to use the term Orange Band Polychrome. Examples of this ware have been recovered from Presidio La Bahía. Even though it has an orange band similar to types in the Aranama Polychrome Tradition, it is not considered part of that tradition here because the pattern is essentially a multi-colored version of Puebla Blue on White. In California it is classified as a variety of the Abó Aranama Polychrome (Cohen-Williams and Williams 2004:8, 44-46) and as the Orange Band Polychrome or Orange Band Polychrome II in Florida (Barnes and May 1972:12-13) where it is one of the earlier majolicas produced during the $19^{\text {th }}$ century (Deagan 1987:88).

\section{General Description}

The pattern is identical to that of Puebla Blue on White and San Elizario Polychrome (below), except that the band under the rim is orange outlined by thin black lines and the suspended floral design is green rather than blue (Figure 4-29). The paste is either cream or pale pink.

\section{Vessel Forms}

Common vessel forms identified include deep brimmed plates (platos, soperos) and cups (tazas, pocillos). Basal sherds are $6 \mathrm{~mm}$ and the thickness varies to about $3 \mathrm{~mm}$ near the rim.

\section{Estimated Dates}

May (1975:123) suggests that the type dates from 1775 to 1850 (see Figure 4-1).

\section{Place of Manufacture}

Orange Band Polychrome was possibly produced in Puebla, Mexico. 


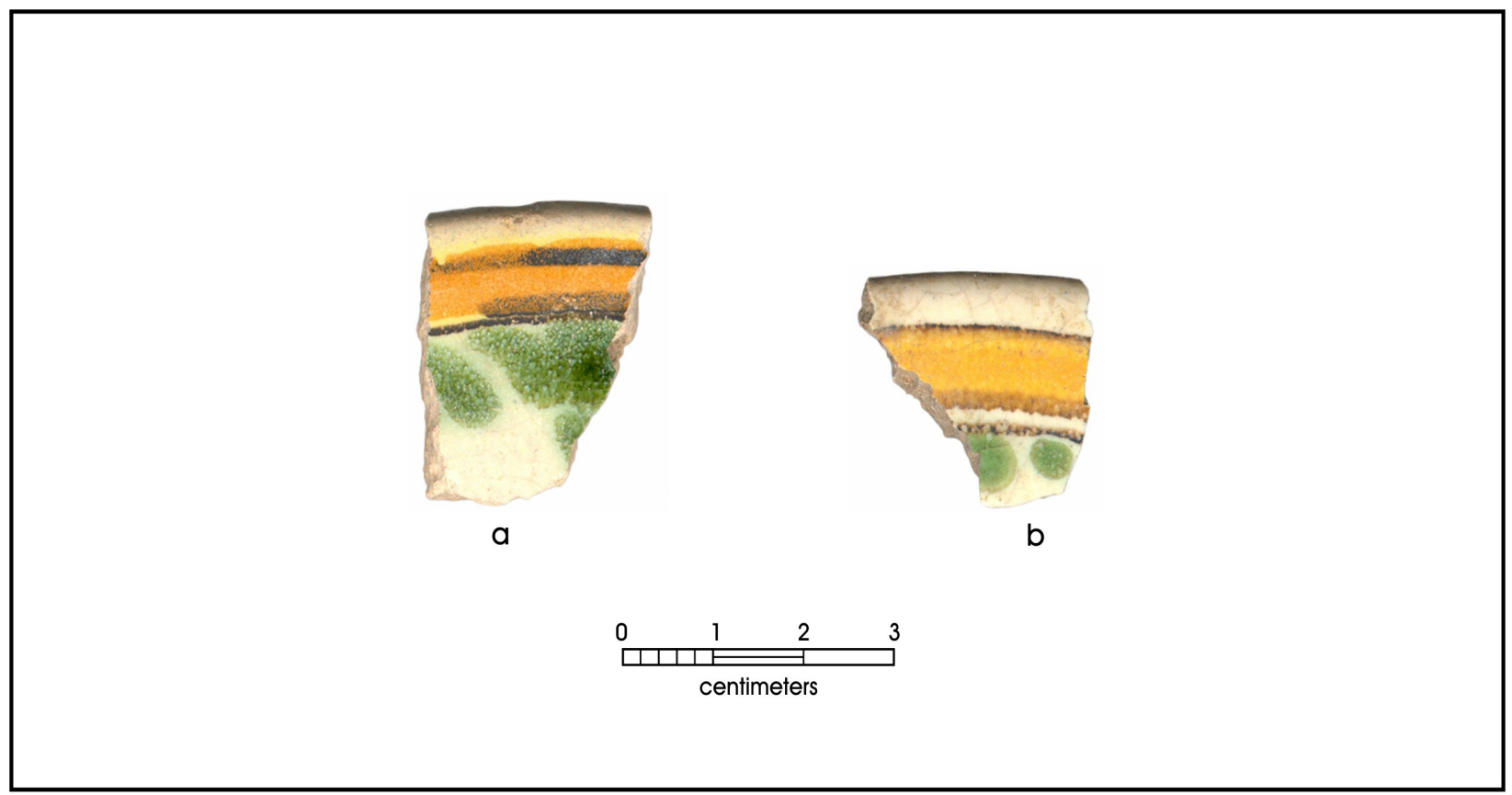

Figure 4-29. Orange Band Polychrome. $41 G D 7 a-b$. 


\section{SAN ELIZARIO POLYCHROME}

San Elizario Polychrome was first defined as a separate type by Gerald (1968:45). It had initially been called Puebla Polychrome II by David Snow (1965:28-29). San Elizario Polychrome is common at many of the Texas Spanish colonial sites. Fragments of San Elizario Polychrome vessels have been recovered from the San Antonio mission sites, Presidio La Bahía, Mission Espíritu Santo, Mission Rosario, Mission Refugio, San Saba, San Agustín Ahumada, San Lorenzo, and Rancho de las Cabras. The type is present in Florida (Deagan 1987:85-86) and is classified as a variety of the Puebla Polychrome in California (Cohen-Williams and Williams 2004:8, 30-33).

\section{General Description}

The overall design is identical to that of Puebla Blue on White with the blue rim band and pendant petals and floral designs below the band. The central design typically consists of a crane-like bird figure. The distinguishing characteristic is that the blue band under the rim has narrow brown/black bands on either side of a blue rim band. Other uses of the brown/black accents include the legs and beaks on a blue crane and/or on blue petals and flowers (Figure 4-30). In essence, this is Puebla Blue on White with brown/black accents added. The paste is primarily pale pink, but there are some cream colored sherds.

\section{Vessel Forms}

Common vessel forms encountered include deep, brimmed plates (platos, soperos), small bowls (escudillas), and cups (tazas, pocillos). Thickness of sherds varies from $6 \mathrm{~mm}$ near the base to $3 \mathrm{~mm}$ near the rim.

\section{Estimated Dates}

The ware is estimated to been prominent in Texas between 1755 and 1780 (Ivey and Fox 1999:37). Authorities suggest that San Elizario was in production from as early as 1750 to possibly 1850 (Goggin 1968; Gerald 1968; see also Figure 4-1).

\section{Place of Manufacture}

San Elizario was possibly produced in Puebla, Mexico since it appears to be a continuation of the Puebla Blue on White tradition. On the other hand, it may be a copy of wares made in Puebla that were made in other manufacturing centers. 


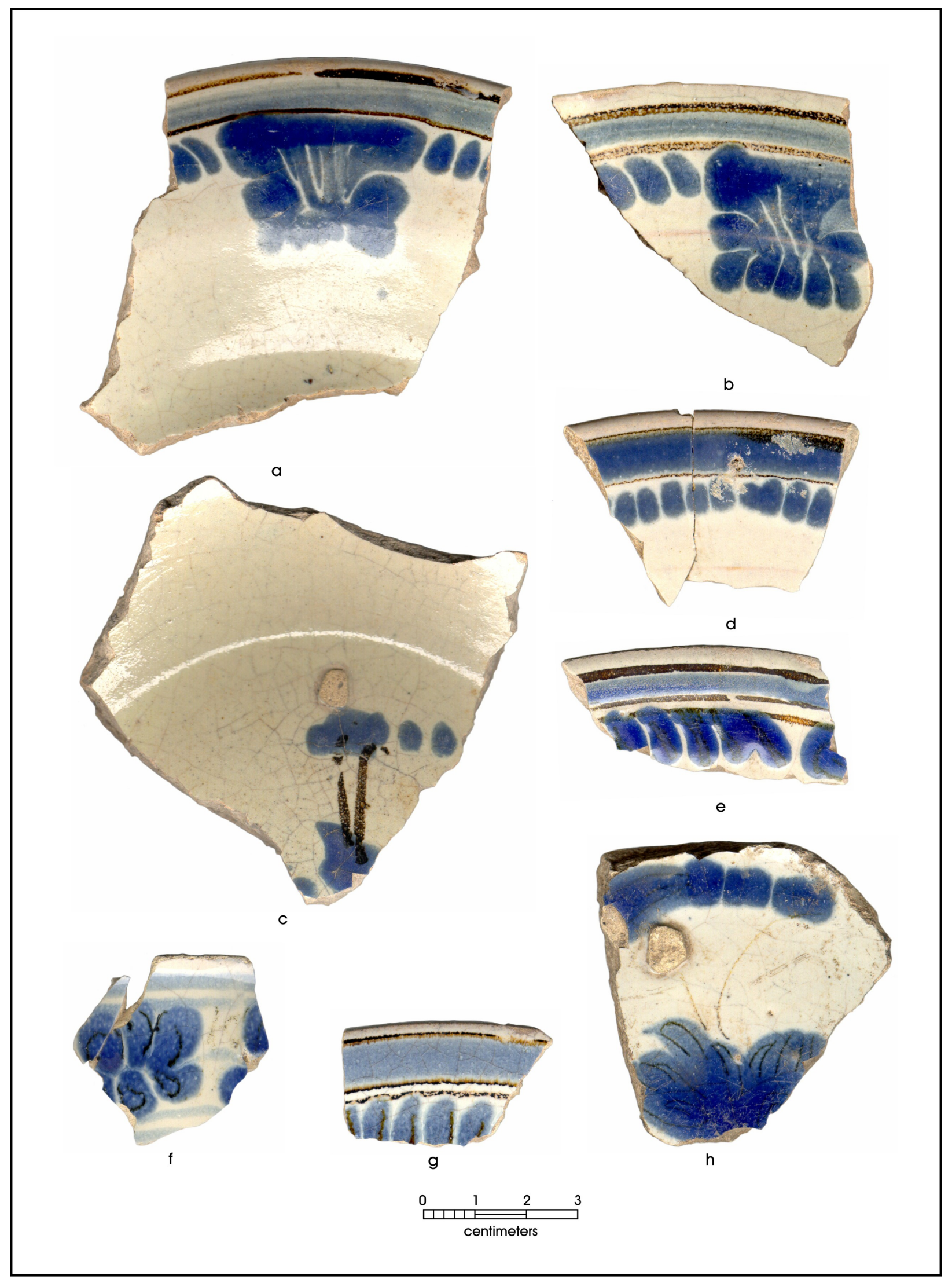

Figure 4-30. San Elizario. 41BX5: a, b, d; 41GD7: $c$, e-h. 


\section{PuEBLA BLUE ON WhITE II}

This type is a variation of Puebla Blue on White that appears only on cups and small bowls. Puebla Blue on White II was first described by Goggin (1968:191), though he did not entirely separate it from Puebla Blue on White at that time. This ware has been identified at Mission Espíritu Santo, Mission Rosario, Mission Refugio, Presidio La Bahía, La Villa de La Bahía, and the San Antonio missions and their surrounding sites. The type is identical to the late variants of the Puebla Blue on White type in Florida (Deagan 1987:84-85), and specimens of the type are lumped into Puebla Blue and White in California (Cohen-Williams and Williams 2004:8, 12-18).

\section{General Description}

The background enamel is identical to that of Puebla Blue on White. The design consists of two or three pale blue bands under the rim on the outside and continuing over onto the inside of the vessel. Below these bands, on the exterior of the vessel, are alternating floral-type arrangements of darker blue petalshaped dots (Figure 4-31). Two additional pale blue bands form the bottom of the design. On some vessels there is a band of smaller petals below this. Others exhibit a trio of dark blue dots that hang from the lowest blue band. The paste is pale tan in color.

\section{Vessel Forms}

The vessel forms encountered in Texas have been delicate cups and bowls only. Vessel walls are $3 \mathrm{~mm}$ thick. This type has a small ring foot on the base.

\section{Estimated Dates}

Figure 4-1 places Puebla Blue and White II in Texas from 1775 to 1800 (Ricklis et al. 2000:110).

\section{Place of Manufacture}

Since this ware is a variation of Puebla Blue on White, it was most likely produced in Puebla, Mexico. 


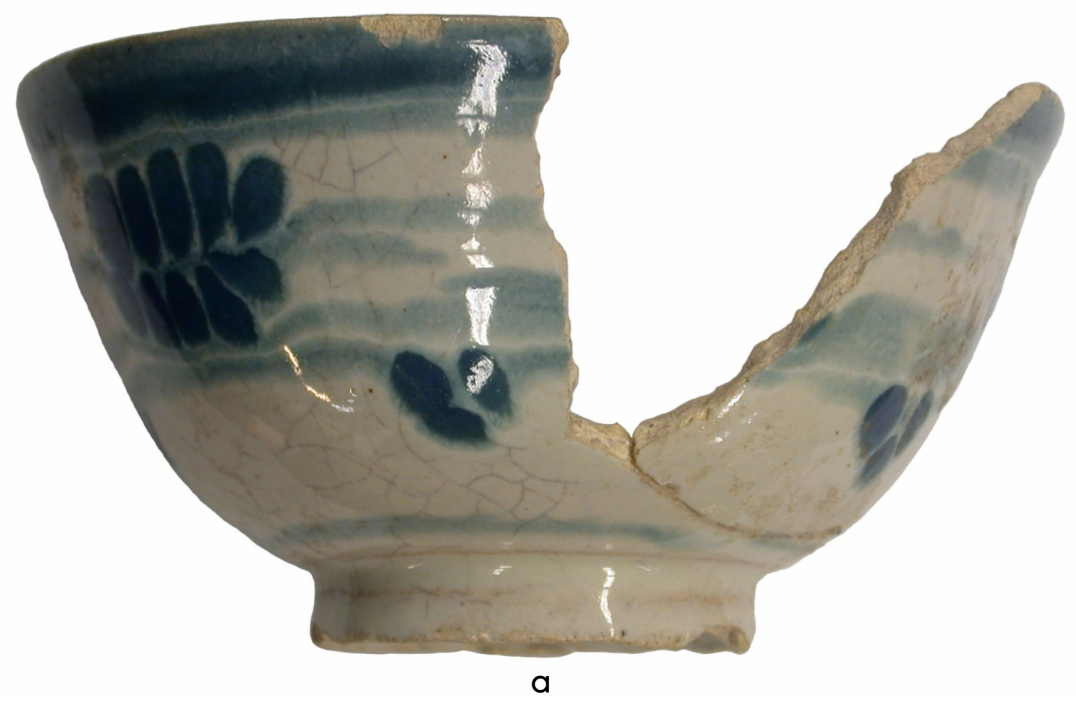

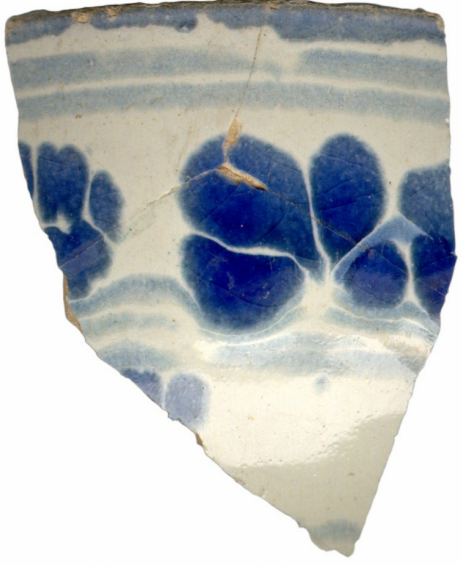

b

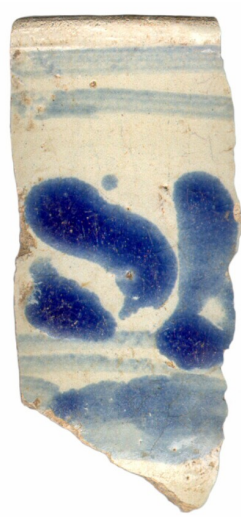

C

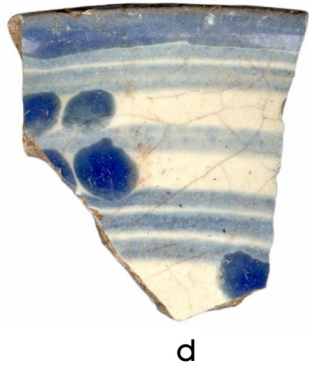

d
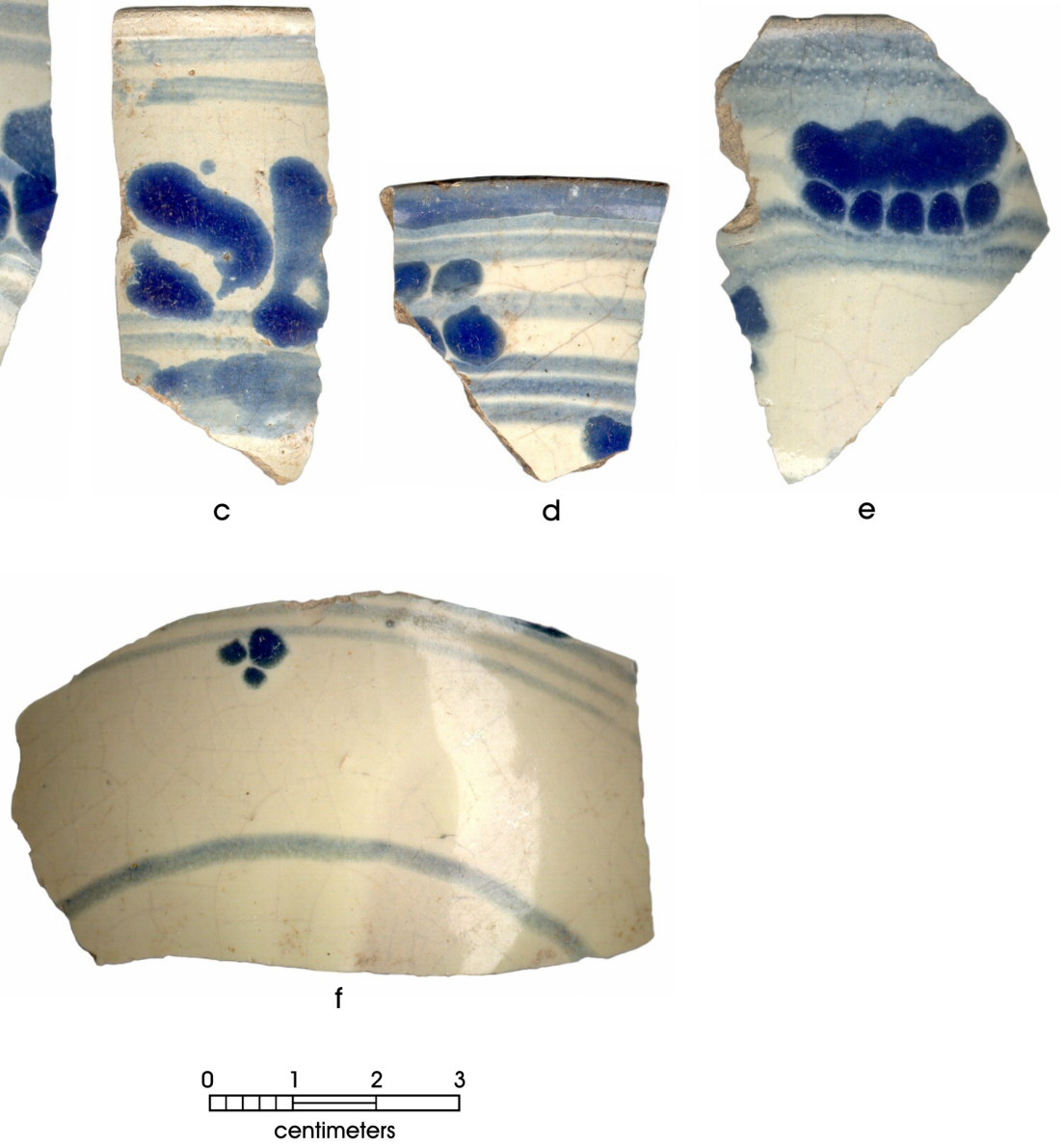

Figure 4-31. Puebla Blue on White II. 41GD7: a-f. 


\section{HUEJOTZINGO WAVY RiM BAND}

This type is a later eighteenth-century version of Huejotzingo Blue on White. As the name indicates, the wavy band along the rim is what separates this type from Huejotzingo Blue on White (see Figure 4-23). As in the case of the Huejotzingo Blue on White, the Wavy Rim Band also has a Blue on White and a Green on White variant. Wavy Rim Band has been recovered from the San Antonio missions and surrounding colonial sites, as well as Mission Refugio, Mission Espíritu Santo, Presidio La Bahía, San Saba, and La Villa de La Bahía. Florida classifications consider the blue on white version a variation within the Huejotzingo type and the yellow or green on white versions to be the Huejotzingo Varient (FLMNH 2007). In California it is classified either as a variant of Puebla Blue on White or a variant of Puebla Green on White depending on the color of the wavy band around the rim of the vessel (CohenWilliams and Williams 2004:8, 21-22, 60-61).

\section{General Description}

The only decoration on these vessels is a band up to, and slightly over, the rim. The lower edge of the band is wavy in shape (Figure 4-32). It is also sometimes found with a green or yellow band instead of a blue one (Figure 4-32e), and occasionally there is a thin band of the same color just below the wavy rim band, or several bands of paler blue beneath the wavy band. The paste is cream in color, but some sherds exhibit a pinkish paste. The glaze is of a creamy white color.

\section{Vessel Forms}

Typical vessel forms exhibiting this style are deep plates (platos, soperos) and cups (tazas, pocillos). The sherds vary from 4 to $5 \mathrm{~mm}$ in thickness.

\section{Estimated Dates}

Dates of popularity of this ware in Texas are from about 1775 to 1825 (Seifert 1977:71; see also Figure 41). May (1972:32) believes that the ware was in production from 1700 to 1800, though Deagan (1987:85) argues that the type was not in existence until 1760.

\section{Place of Manufacture}

Wavy Rim Band was produced in Puebla and perhaps elsewhere in Mexico. 


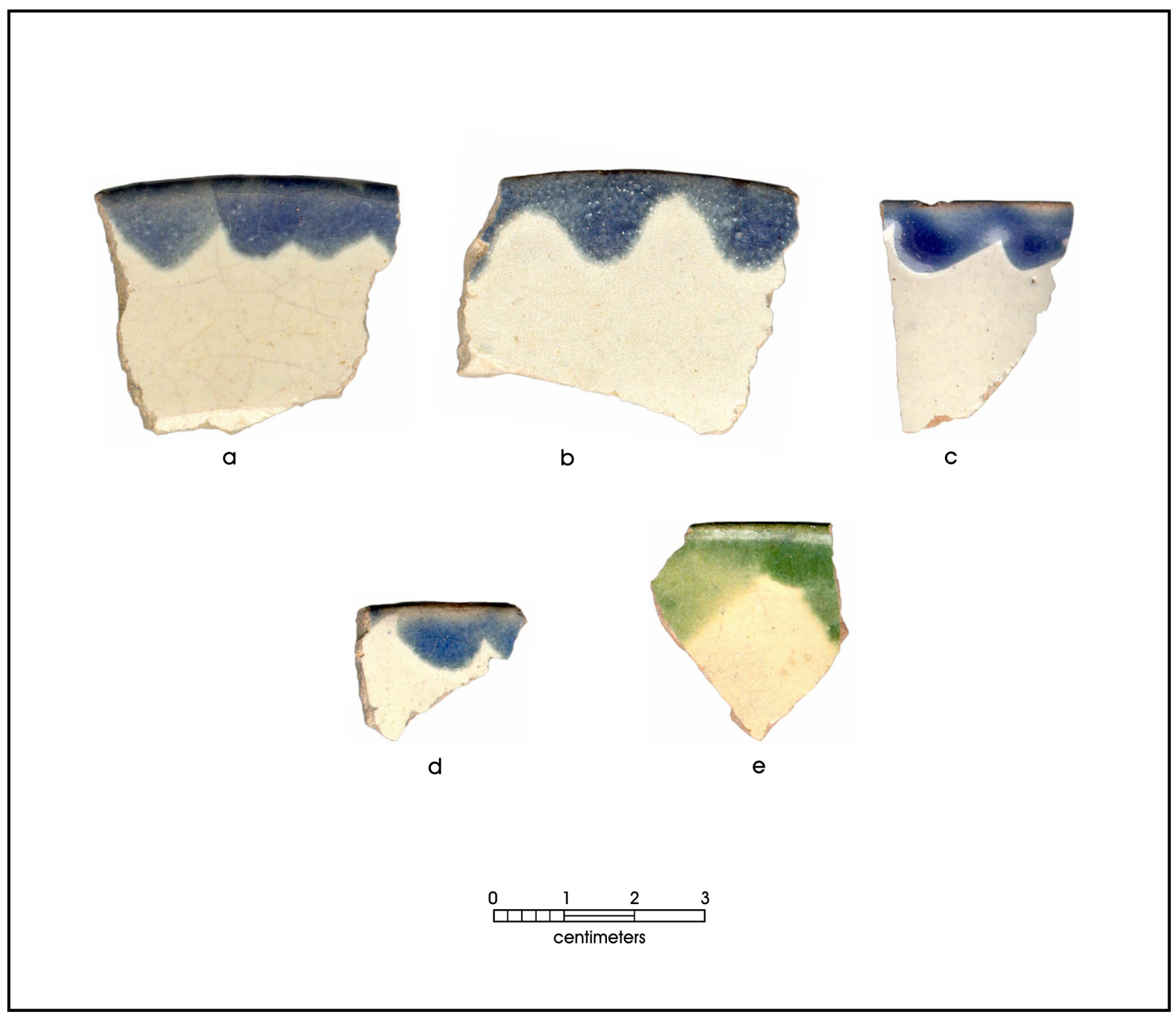

Figure 4-32. Huejotzingo Wavy Rim Band. 41GD7: a-c, e; 41BX 5: d. 


\section{Puebla Blue on Blue}

In Texas, this type was first described by Schuetz (1969:56) in her report on excavations at Mission San Juan Capistrano in San Antonio, Texas. At this point very little is known about this type. In Florida, it is considered a Blue Wash Variant of the Puebla Blue on White Type (FLMNH 2007). It does not appear to be present in California (Cohen-Williams and Williams 2004:8).

\section{General Description}

In manufacturing these vessels, the white glazed plate interiors were brushed with a thin blue wash over which dark blue floral and geometric designs with occasional black accents were painted (Figure 4-33). A dark blue rim band extends over the lip. Pale blue interconnected loops are on the reverse side of the vessel, similar to those on San Agustín plates.

\section{Vessel Forms}

The sherds recovered in Texas indicate that the vessels consisted of deep, brimmed plates (platos).

\section{Estimated Dates}

Puebla Blue on Blue appears to have been used in Texas during the late eighteenth century to early nineteenth century. We suggest a date range of 1775 to around 1830 (see Figure 4-1).

\section{Place of Manufacture}

This type was manufactured in Puebla, Mexico (Lister and Lister 1974:34). 


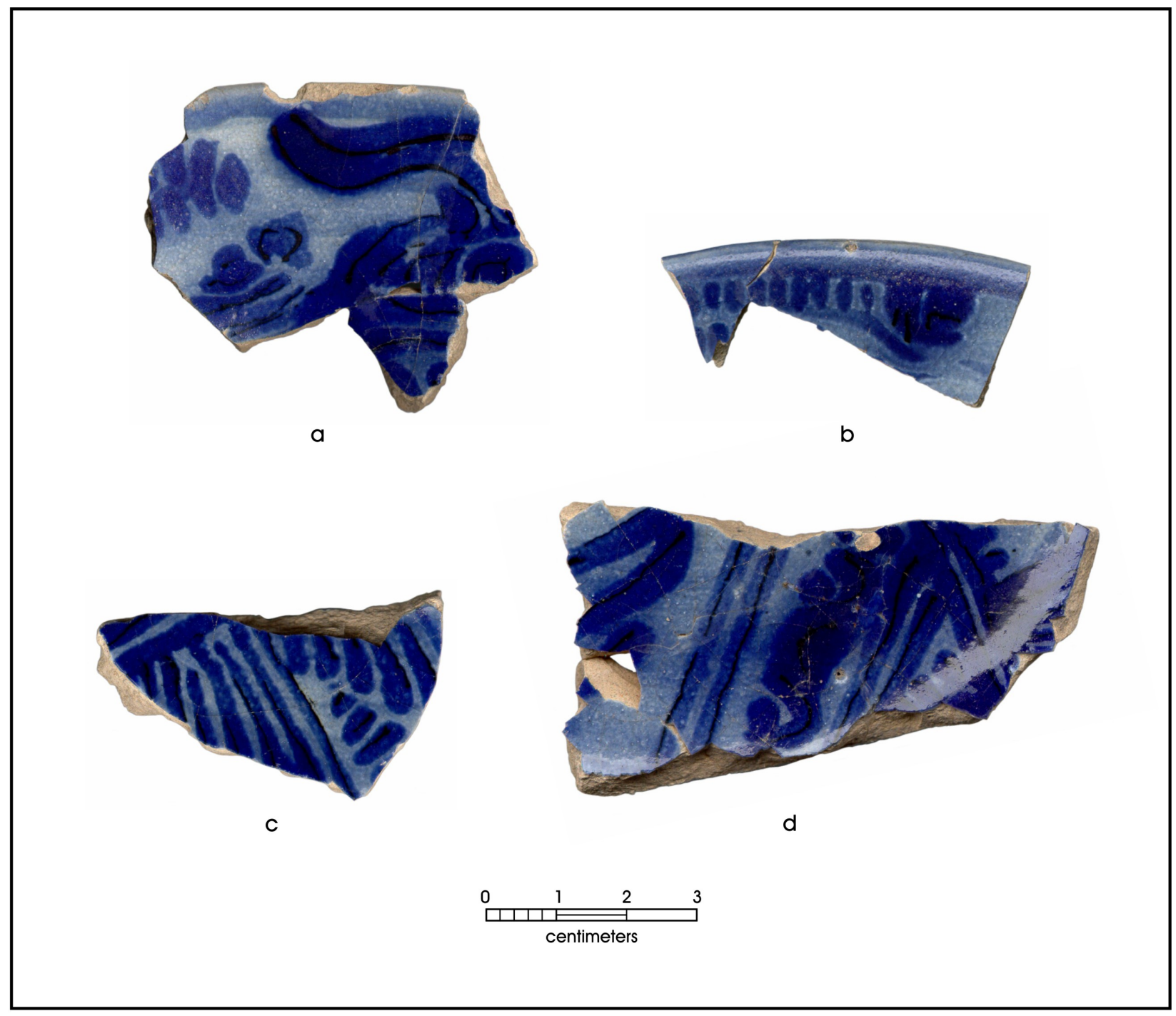

Figure 4-33. Puebla Blue on Blue. $41 B X 5$ a-d. 


\section{THIN BLUE AND BROWN ON WHITE}

Schuetz isolated this ware in her report on the Mission San Juan Capistrano excavations (Schuetz 1969:57). Additional sherds were recovered from Mission Rosario near Goliad (Gilmore 1975:Type Q) and Mission San José in San Antonio (Tomka and Fox 1998:25). It is possible that the distribution of the ware is limited to Texas since no identical specimens have been reported from Florida or California (i.e., Deagan 1987; Cohen-Williams and Williams 2004). We do not have a very good understanding of the relationship of this ware to other Spanish Colonial ceramics, and have chose not to type the ware.

\section{General Description}

These vessels are covered with a creamy white glaze. Decoration consists of small blue and brown floral designs (Figure 4-34). The sherds encountered form cups that are extremely thin, $1.7 \mathrm{~mm}$ at the rim to 5.7 $\mathrm{mm}$ at the base. Plate sherds range in thickness from $4.5 \mathrm{~mm}$ to $5 \mathrm{~mm}$. Thin Brown and Blue on White appears to have been a fine and delicate ware.

\section{Vessel Forms}

Pieces recovered are usually too small to determine anything more than that they represent small cups and heavier plates.

\section{Estimated Dates}

Production of this ware is estimated to the late eighteenth century, due to its recovery from Mission Rosario. We estimate a date range of 1775 to 1800 (Figure 4-1).

\section{Place of Manufacture}

Due to the little information known at the time concerning this ware, the location of manufacture is unknown. 


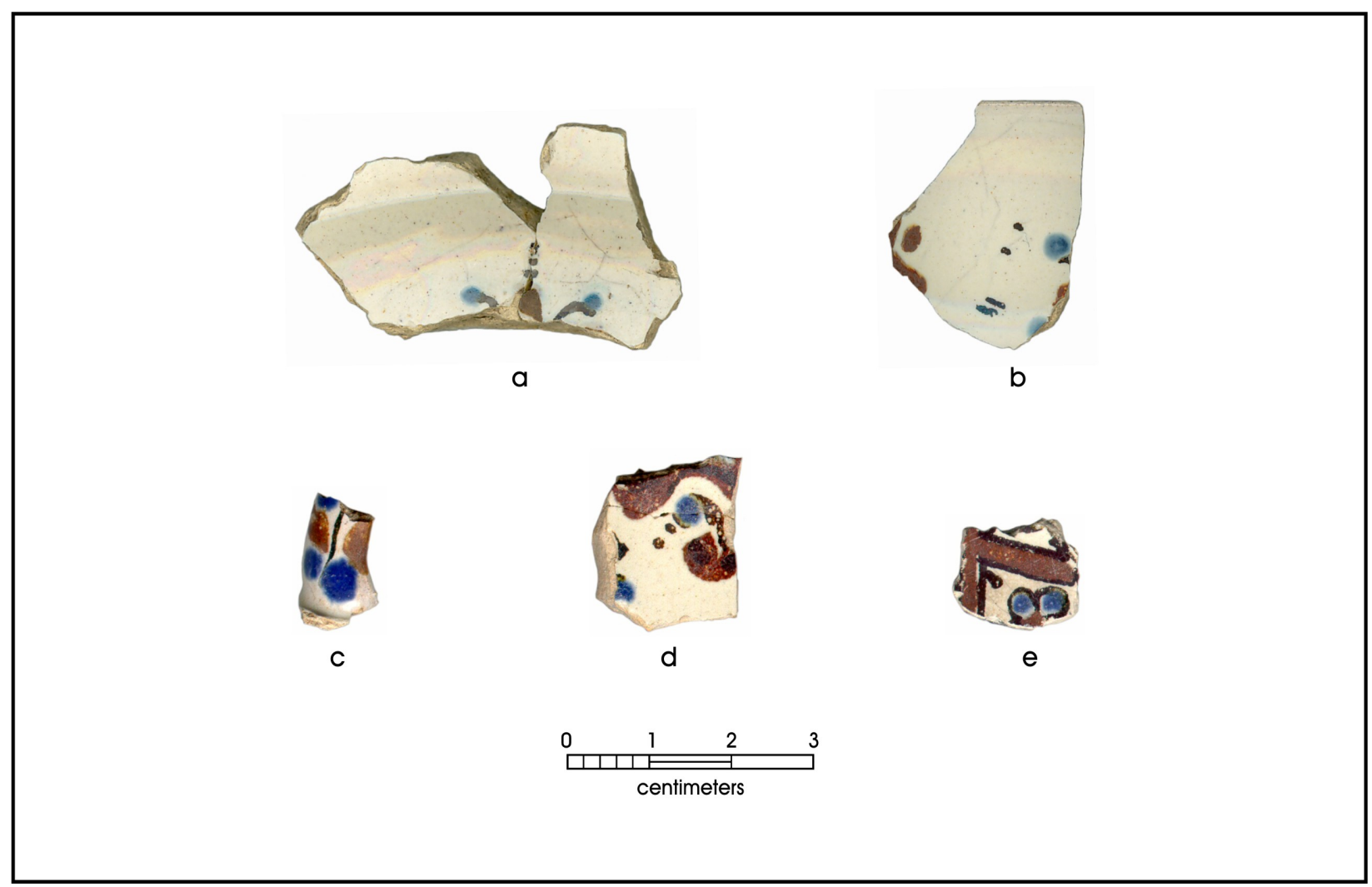

Figure 4-34. Thin Blue and Brown on White. 41BX5: a, b; 41GD7: c-e. 


\section{Nineteenth CentuRY}

Relatively little has been done with ceramics dated after the secularization of the Spanish mission sites in Texas. Seifert's (1977) dissertation, Archaeological Majolicas of the Rural Teotihuacan Valley, Mexico, was the first to organize and name individual types for the post-1800 period in Mexico. The types she identified occasionally occur on Texas mission, presidio sites, and settlements where the Hispanic occupation continued into the nineteenth century and was still supplied from Mexico. There are so few of Seifert's majolica types in the Texas mission collections that they are not included here in detail.

\section{TUMACACORI POLYCHROME}

Goggin (1968:190-200) initially described this ware. Tumacacori is one of the easiest majolica types to be defined due to its distinctive blue glaze, similar to the color of a Robin's egg. Tumacacori has been recovered from the missions and late colonial sites in San Antonio, as well as from Presidio La Bahía, Mission Rosario, La Villa de La Bahía, and Mission Refugio. The type is present in $19^{\text {th }}$ century sites in both Florida (Deagan 1987:90) and California (Cohen-Williams and Williams 2004:8,66-69).

\section{General Description}

All vessel surfaces are covered with thick pale blue enamel over a cream-colored paste (Figure 4-35). Designs consist of a linear floral decoration below an undulating rim. Barnes (Barnes and May 1972:11) was able to identify three different rim designs and separate them into time periods based on stratification in deposits recorded at the Tucson Urban Renewal Project.

$$
\begin{aligned}
& \text { Tumacacori I - } 1780-1790 \text { to } 1810-1820 \\
& \text { Tumacacori II - } 1810-1820 \text { to } 1830-1840 \\
& \text { Tumacacori III - } 1830-1840 \text { to } 1850-1860
\end{aligned}
$$

Tumacacori II and III have been found on sites in the San Antonio vicinity. Central floral designs are seldom represented in Texas sites, but Goggin (1968:199) mentions large floral designs as central decoration on plates.

\section{Vessel Forms}

Typical vessel forms encountered in Texas include shallow plates (platos), platters (lebrillos), cups (tazas, pocillos), and bowls (escudillas). Sherds from the base are about $5 \mathrm{~mm}$ in thickness. Near the rim they thin out to approximately $3 \mathrm{~mm}$. 


\section{Estimated Dates}

According to the variations of Tumacacori recovered in Texas, the estimated dates are early to midnineteenth century. We suggest an 1820 to 1860 range (Figure 4-1).

\section{Place of Manufacture}

Tumacacori was probably produced at Puebla, Mexico (Goggin 1968:200).

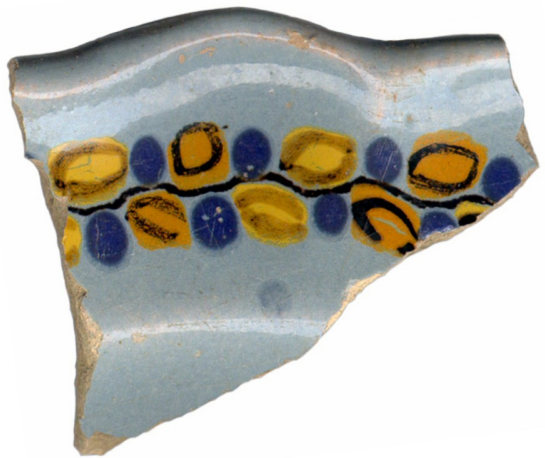

a

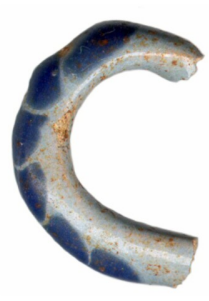

d

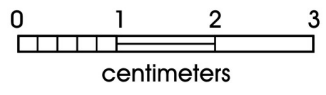

e

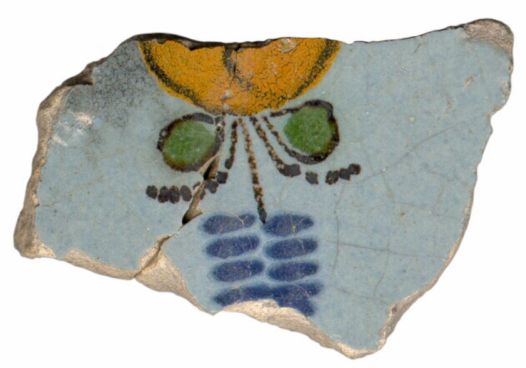

C

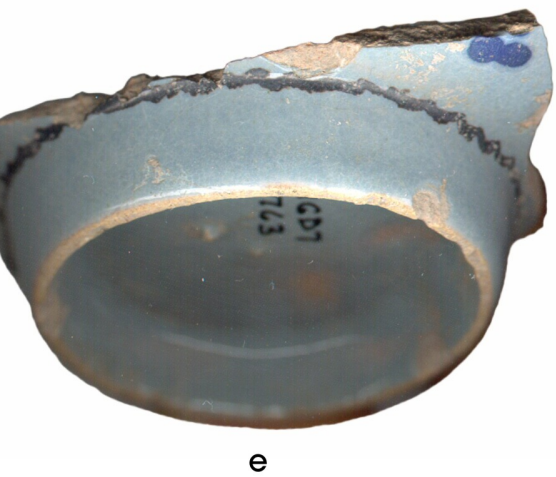

Figure 4-35. Tumacacori Polychrome. 41GD7: a, c-e; 41BX6: b. 


\section{GuANAJUATO POLYCHROME}

Father Hidalgo is said to have encouraged the development of a ceramic industry in Guanajuato, Mexico in the early 1800s (Lister and Lister 1974:1). By the early nineteenth century, a new ceramic type appeared which exhibited the use of color schemes unlike previously made ceramics. This type was named for the area where it was initially produced. These wares are found on all Spanish Colonial sites in the San Antonio River Valley, as well as early-nineteenth-century sites in Laredo (Clark and Juarez 1986; Folan et al. 1986) and at Mission Refugio (Fox 2002:12). The type is present in Florida (FLMNH 2007) but there appears to be no mention of it in California typologies.

\section{General Description}

The paste of these wares is dark terra cotta. The background enamel often has a slightly greenish cast, although sometimes it appears with a yellow tinge. Decoration is primarily geometric, dot patterns, and wavy lines in rust, green, yellow, and black-brown (McKenzie 1989:1). Stylized floral motifs and geometric patterns exhibited on the sherds from Texas sites are common to the type (Figure 4-36). There are various design motifs evident within the Guanajuato typology, which, though acknowledged, have not been separated into individual categories.

\section{Vessel Forms}

Typical vessel forms encountered from Texas colonial sites include deep, brimmed plates (platos, soperos), cups (tazas, pocillos), and shallow bowls. Basal sherds are $5 \mathrm{~mm}$ thick, gradually thinning to 3 mm near the rim.

\section{Estimated Dates}

Guanajuato is one of later-produced majolicas, appearing during the early nineteenth century. We estimate a range of 1800 to 1850 (Figure 4-1).

\section{Place of Manufacture}

Guanajuato, Mexico. 


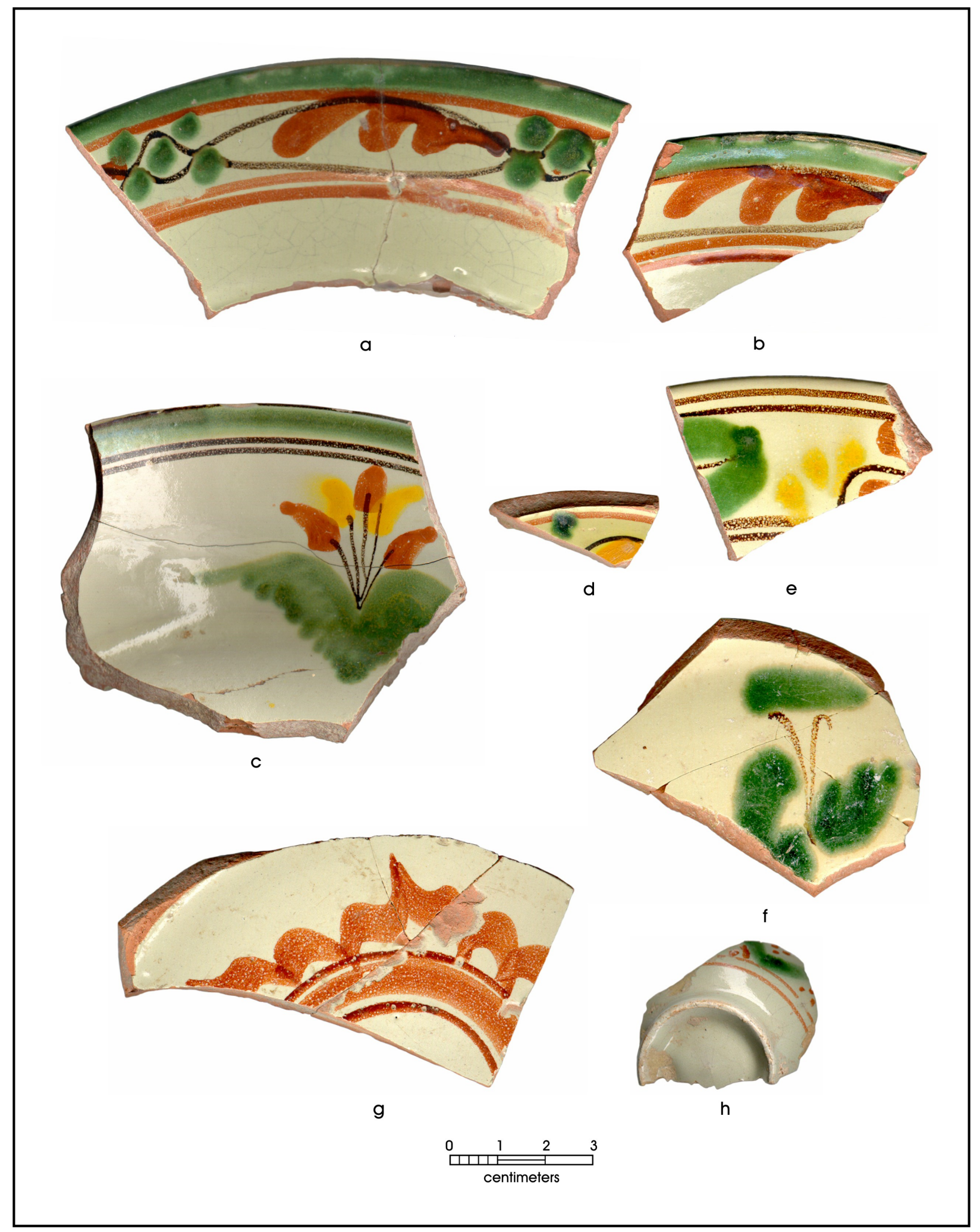

Figure 4-36. Guanajuato Polychrome. 41BX6: $a$; 41BX5: b, f; 41GD7: $c$ - e, g, $h$. 


\section{FAIENCE}

\section{General Description}

Tin-glazed earthenwares made in France have commonly been called faience. Lane (1970), Avery (2008), and Waselkov and Walthall (2002) provide excellent resources for further information on faience wares. Although at first glance they may seem to be majolica, a closer study reveals basic differences between the two. For the most part, the paste is fine-grained, ranging from near white to pale buff. A common characteristic is the tendency of the enamel to flake off a sherd, leaving sections of the paste exposed.

There are two common types of faience found in Texas. Faience blanche has a white tin glaze covering all surfaces. Faience brune has white or very pale blue on the inside surface and dark brown lead glaze on the outside. Faience brune was made in Rouen, Normandy. The brown glaze was believed to withstand heat better and vessels of this type were used primarily for cooking. Faience blanche was used as tableware (Blanchette 1981:33). This type was decorated in simple blue rim bands and border patterns borrowed from Chinese porcelains (Figure 4-37). Ointment jars, often referred to as rouge pots (see Figure 3-4), in green and blue have interiors lined with white tin glaze. They have a rolled rim, probably to facilitate the attachment of some sort of protective lid or covering. A distinctly different type found on the first site of the presidio at Orcoquisac on the Trinity River consists of a yellow floral design on a white background. This has been identified as Provence Yellow on White (Walthall 1991:90).

\section{Vessel Forms}

Typical vessel forms recovered in Texas include shallow bowls, plates, platters, cups, and ointment jars. Sherds are on the whole thicker and clumsier than majolica.

\section{Estimated Dates}

Production of faience was begun in the early part of the eighteenth century and reached its height of development by 1730 (Brain 1979:35). The presence of faience on Spanish sites in Texas is probably indicative of contact with French outposts in Louisiana (Calhoun 1999:350). The French were active traders and it is interesting to note that the closer a Spanish site was to that border, the larger the percentage of faience versus majolica in the collection.

\section{Place of Manufacture}

Most faience brune was made in Normandy, particularly in and around Rouen. Faience blanche was also made in Normandy as well as in the south of France (Blanchette 1981:33). 


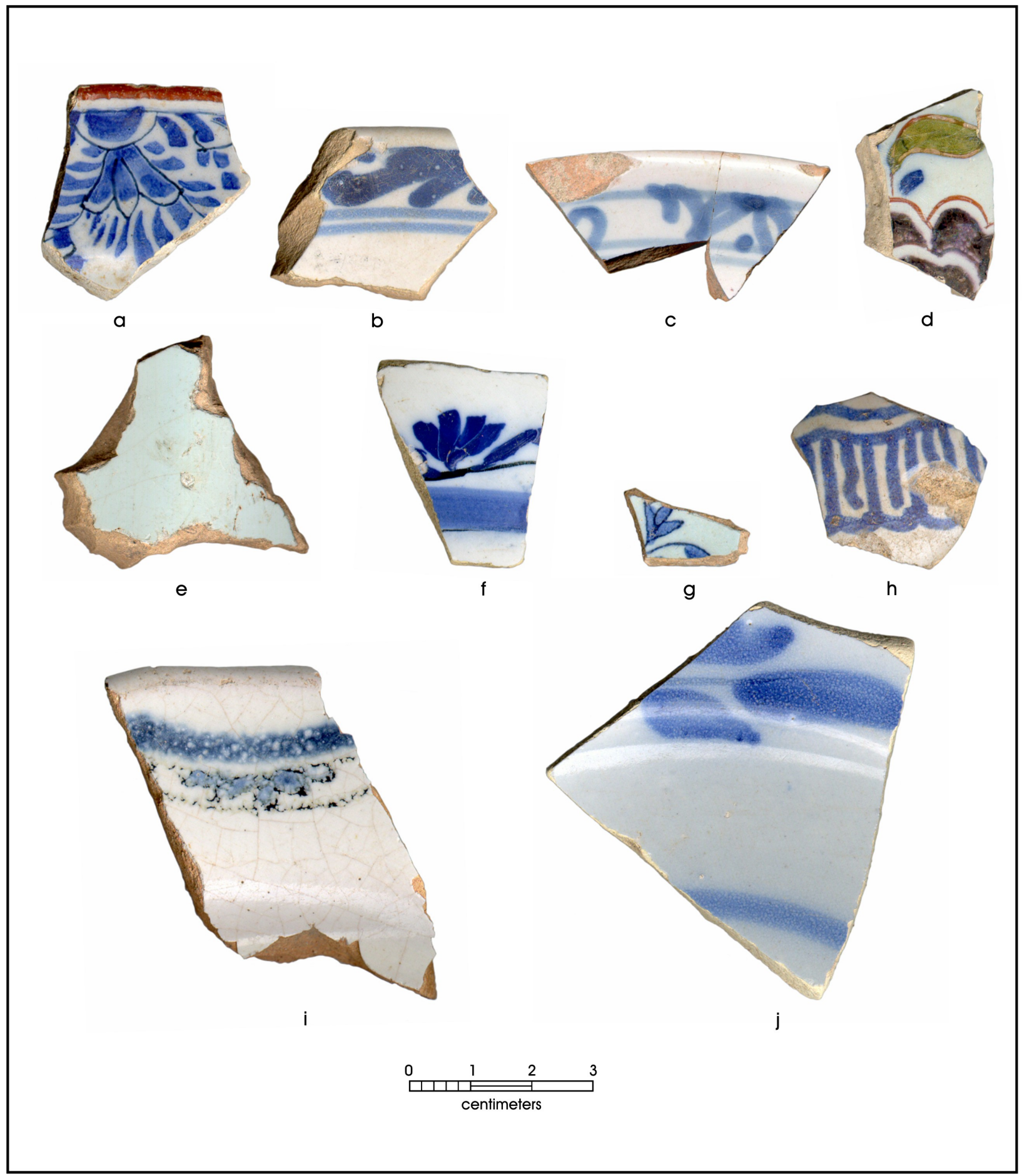

Figure 4-37. Faience. 41GD7: a, c-g, j; 41WN30: b; 41CH51: h; 41BX5: $i$. 


\section{CHINESE PORCELAIN}

Porcelain vessels were regularly transported on galleons from the Philippines to Acapulco throughout the eighteenth century. They were off-loaded there and packed onto mules for the arduous trip to Mexico City. They were then purchased by procurators for the missions and presidios and loaded again onto mules for the long trip to the Texas frontier.

\section{General Description}

Chinese porcelain can generally be differentiated from European porcelain by its slightly blue-gray tint and the delicate thinness of the sherds. Two common varieties of Chinese porcelain are found in Texas. One exhibits decoration with predominant designs in under-glaze blue (Figure 4-38 a-f). The second variety exhibits designs painted in over-glaze red-orange and gold (Figure 4-38 g-m) that began to appear about 1750. Places of manufacture within China can be determined from the theme of the designs on the vessels (Longoria 2007).

\section{Vessel Forms}

The Chinese vessel forms encountered at Texas sites are primarily cups without handles (tea bowls) and small plates or saucers. Sherds are generally $3 \mathrm{~mm}$ in thickness.

\section{Estimated Dates}

The Chinese porcelain imported and brought to Texas was from the Ching Dynasty (1644-1912). The first variety with under-glaze gold and red and under-glaze blue dates to the first half of the eighteenth century (Deagan 1987:100-101). The second variety with over-glaze gold and red dates to the last half of the eighteenth century. In Texas, we suggest a range of from 1680 to 1820 (Figure 4-1).

\section{Place of Manufacture}

China. 


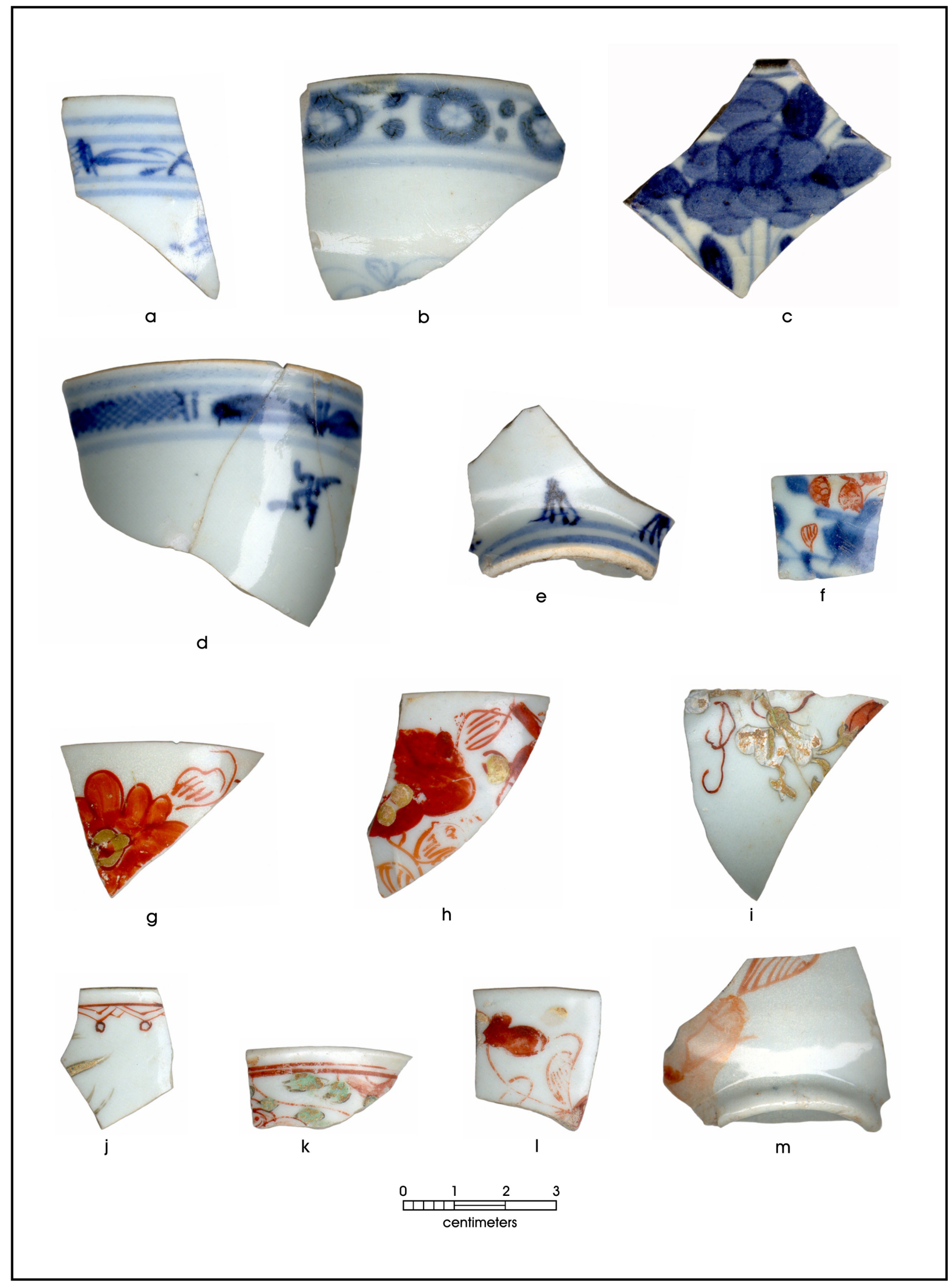

Figure 4-38. Chinese Porcelains. 41GD7: $a, b, e, f, h-m ; 41 B X 3: c ; 41 W N 30: g$ 


\section{REFERENCES CITED}

Avery, G. E.

1997 Pots as Packaging: The Spanish Olive Jar and Andalusian Transatlantic Commercial Activity, $16^{\text {th }}-18^{\text {th }}$ Centuries. Unpublished Doctoral Dissertation, University of Florida. Gainesville.

2008 French Colonial Pottery: An International Conference. Northwestern State University of Louisiana Press.

Bannon, J.F.

1974 The Spanish Borderlands Frontier, 1513-1821. University of New Mexico Press, Albuquerque.

Barnes, M.R.

1980 Mexican Lead-Glazed Earthenwares. In Spanish Colonial Frontier Research, compiled and edited by H. F. Dobyns. Spanish Borderlands Research 1:91-110. Center for Anthropological Studies, Albuquerque.

Barnes, M.R. and R.V. May

1972 Mexican Majolica in Northern New Spain. Occasional Paper No. 2. Pacific Coast Archaeological Society, Costa Mesa.

Blanchette, J.

1981 The Role of Artifacts in the Study of Foodways in New France, 1720-60. History and Archaeology No. 52. National Historic Parks and Sites Branch, Parks. Canada.

Benowitz, J.M.

1996 Nuestra Señora del Refugio Mission. The New Handbook of Texas, edited by R. Tyler, Vol. 4:1072-1073. Texas State Historical Association, Austin.

Brain, J.P.

1979 Tunica Treasure. Papers, Vol. 71. Peabody Museum of Archaeology and Ethnology, Harvard University, Cambridge, and the Peabody Museum of Salem, Salem.

Burke, J.W.

1971 Missions of Old Texas. A.S. Barnes and Co., Inc. Cranbury, New Jersey.

Calhoun, C.A.

1999 Majolica and Faience from the Presidio Loreto Site (41VT8). Bulletin of the Texas Archeological Society 70:339-354.

Cargill, D.A., M. Brown, L.C. Nordt, and C.B. Bousman.

1998 Archaeological Survey at Rancho de las Cabras, San Antonio Missions National Historical Park, 41WN30, Wilson County, Texas. Archaeological Survey Report No. 268. Center for Archaeological Research, The University of Texas at San Antonio.

Cargill, D.A., B.A. Meissner, A.A. Fox, I.W. Cox, and J.D. Weston

2004 San Antonio Mission Trails, Statewide Transportation Enhancement Project Volume I, Construction Package 1, Archeological Investigations at Mission San Francisco de la Espada 
(41BX4), City of San Antonio, Bexar County, Texas. Archaeological Survey Report No. 308. Center for Archaeological Research, The University of Texas at San Antonio.

Carlson, S. B.

2007 Cultural Connections: Colonial Ceramics in Texas and Mexico. Paper presented at the $72^{\text {nd }}$ Annual Meeting of the Society for American Archaeology, April 25-29, 2007. Austin, Texas.

Caywood, L.R.

1950 Hispanic Pottery as a Guide in Historical Studies. In For the Dean, edited by E.K. Reed and D.S. King, pp. 77-97. Hohokam Museum Association, Tucson, and Southwestern Monuments Association, Santa Fe.

Charlton, T.H. and R.R. Katz

1979 Tonalá Bruñida Ware. Archaeology 32(1):45-53.

Chipman, D.E.

1984 Spanish Texas, 1519-1821. University of Texas Press, Austin.

1992 San Francisco Xavier Mission on the Guadalupe River. In The New Handbook of Texas, edited by R. Tyler, Vol. 5:849. Texas State Historical Association, Austin.

Clark, J.W. and A.M. Juarez

1986 Urban Archaeology: A Culture History of a Mexican American Barrio in Laredo, Webb County Texas, Volume 1. Publications in Archaeology Report No. 31. Design Division, Texas State Department of Highways and Public Transportation, Austin.

Cohen-Williams, A.G.

1992 Common Majolica Types of Northern New Spain. Historical Archaeology 26:119-130.

Cohen-Williams, A. and J. Williams

2004 Reconstructing Maiolica Patterns from Spanish Colonial sites in Southern California. Available online at http://www.colonialmaiolica.com/maiolica01.pdf. Accessed February 23, 2007.

Cox, I.W.

2005 The Spanish Acequias of San Antonio. Maverick Publishing Company, San Antonio.

Cox, I.W. and O. Ford

2001 The History of the Carvajal Crossing. In Archaeological Investigations at a Spanish Colonial Site (41KA26-B), Karnes County, Texas, by C.L. Tennis, pp. 9-13. Archeological Studies Program Report No. 26. Environmental Affairs Division, Texas Department of Transportation, Austin, and Archaeological Survey Report No. 302. Center for Archaeological Research, The University of Texas at San Antonio.

Deagan, K.K.

1983 Spanish St. Augustine: The Archaeology of a Colonial Creole Community. Academic Press, New York.

1987 Artifacts of the Spanish Colonies of Florida and the Caribbean, 1500-1800, Volume 1: Ceramics, Glassware, and Beads. Smithsonian Institution Press, Washington, D.C. 
de la Teja, J.F.

1995 San Antonio de Béxar: A Community on New Spain's Northern Frontier. University of New Mexico Press, Albuquerque.

Fairbanks, C.H.

1973 The Cultural Significance of Spanish Ceramics. In Ceramics in America, Winterthur Conference Report 1972, edited by I.M.G. Quimby, pp. 141-74. The Henry Francis du Pont Winterthur Museum, Winterthur.

Faulk, O.B.

1996 Presidios. The New Handbook of Texas, Edited by R. Tyler, Vol. 5:333-334. Texas State Historical Association, Austin.

Fisher, L.F.

1998 The Spanish Missions of San Antonio. Maverick Publishing Company, San Antonio.

Florida Museum of Natural History (FLMNH)

2007 Historical Archaeology at the Florida Museum of Natural History Digital Type Collection. http://www.flmnh.ufl.edu/histarch/gallery types/. Last accessed Dec. 6, 2007.

Folan, W.J., I.W. Cox, A.A. Fox, and G.M. Hinojosa

1986 Laredo, Texas: A Gateway Community on the Texas Borderlands: Archaeological and Historical Investigations for the Laredo City Toll Plaza (41WB36, 37, and 38). Archaeological Survey Report No. 116. Center for Archaeological Research, The University of Texas at San Antonio.

Foster, W.C.

1995 Spanish Expeditions into Texas 1689-1768. University of Texas Press, Austin.

1998 The La Salle Expedition to Texas: The Journal of Henri Joutel 1664-1687. Texas State Historical Association, Austin.

Fox, A.A.

2000 General Historical Background. In 1999 Excavations at Mission Rosario, by D.L. Nickels, pp. 36. Archaeological Survey Report No. 298. Center for Archaeological Research, The University of Texas at San Antonio.

2002 Ceramics. In Archaeological Investigations at the Last Spanish Colonial Mission Established on the Texas Frontier: Nuestra Señora de Refugio (41RF1), Refugio County, Texas. Volume I: Archaeological Investigations, by C.L. Tennis, pp. 203-219. Archeological Studies Program Report No. 39, Environmental Affairs Division, Texas Department of Transportation, Austin, and Archaeological Survey Report No. 315, Center for Archaeological Research, The University of Texas at San Antonio.

Fox, A.A., and T.R. Hester

1976 The Archaeology and History of Alamo Plaza. Archaeological Survey Report No. 16. Center for Archaeological Research, The University of Texas at San Antonio.

Gerald, R.E.

1968 Spanish Presidios of the Late Eighteenth Century in Northern New Spain. Research Records No. 7, Museum of New Mexico, Museum of New Mexico Press, Santa Fe. 
Gilmore, K.

1973 The Keeran Site, The Probable Site of LaSalle's Fort St. Louis in Texas. Report No. 24. Office of the State Archeologist, Texas Historical Commission, Austin.

1974 Mission Rosario, Archeological Investigations 1973. Archeological Report No. 14, Part 1, Historic Sites and Restoration Branch, Texas Parks and Wildlife Department, Austin.

Goggin, J.M.

1964 The Spanish Olive Jar: Indian and Spanish Selected Writings. University of Miami Press, Coral Gables.

1968 Spanish Majolica in the New World. Yale University Publications in Anthropology No. 17. Yale University Press, New Haven.

Greer, J.W.

1967 A Description of the Stratigraphy, Features and Artifacts from an Excavation at the Alamo. Archaeological Program Report No. 3. State Building Commission, Austin.

Gregory, H.F.

1980 Excavations: 1979, Presidio Nuestra Señora del Pilar de Los Adaes. Divisions of State Parks, State Department of Culture, Recreation, and Tourism, Baton Rouge.

Habig, M.A.

1968a The Alamo Chain of Missions: A History of San Antonio's Five Old Missions. Franciscan Herald Press, Chicago.

1968b San Antonio's Mission San José: State and National Historic Site 1720-1968. Nalor, San Antonio.

1990 Spanish Texas Pilgrimage: The Old Franciscan Missions and Other Spanish Settlements of Texas 1632-1821. Franciscan Herald Press, Chicago.

Habig, M.A. (compiler)

1978 The San José Papers: The Primary Sources for the History of the Mission San José y San Miguel de Aguayo from Its Founding in 1720 to the Present. Part I: 1719-1791. Translated by B. Leutenegger et al. Old Spanish Missions Historical Research Library at Mission San José, San Antonio.

Hackett, C.W.

1945 Marquis of San Miguel de Aguayo and His Recovery of Texas from the French 1719-1723. Southwestern Historical Quarterly Online 49(2): 193-214, available at http://www.tsha.utexas.edu/publications/journals/shq/online/v049/n2/contrib_DIVL2796.html. Accessed January 10, 2007.

Handbook of Texas

1996 Presidio San Antonio de Béxar. The Handbook of Texas. Vol. 5:826. Texas State Historical Association, Austin.

Hester, T.R.

1989 Perspectives on the Material Culture of the Mission Indians of the Texas-Northeastern Mexico Borderlands. In Columbian Consequences, Vol. 1: Archaeological and Historical Perspectives on the Spanish Borderlands West, edited by D.H. Thomas, pp. 213-230. Smithsonian Institution Press, Washington D.C. 
Hinojosa, G.M.

1991 The Religious-Indian Communities: The Goals of the Friars. In Tejano Origins in EighteenthCentury San Antonio, edited by G.E. Poya and G.M. Hinojosa, pp. 61-83. University of Texas Press, Austin.

Ivey, J.E.

1983 Archaeological Testing at Rancho de las Cabras, 41WN30, Wilson County, Texas Second Season. Archaeological Survey Report No. 121. Center for Archaeological Research, The University of Texas at San Antonio.

1984 The San Antonio Missions. Unpublished manuscript on file at the Center for Archaeological Research, The University of Texas at San Antonio.

Ivey, J.E., and A.A. Fox

1981 Archaeological Survey and Testing at Rancho de las Cabras, Wilson County, Texas. Archaeological Survey Report No. 104. Center for Archaeological Research, The University of Texas at San Antonio.

1999 Archaeological Investigations at Mission Concepción and Mission Parkway. Archaeological Survey Report No. 114. Center for Archaeological Research, The University of Texas at San Antonio.

John, E. A.H.

1975 Storms Brewed in Other Men's Worlds: The Confrontation of Indians, Spanish, and French in the Southwest, 1540-1795. Texas A\&M University Press, College Station.

Krase, J.

1981 Ships and Sherds: Ceramics at the San Diego Presidio. The Journal of San Diego History 27(2):129-41.

Lakeman, J.B.

2001 An Analysis of the Ceramic Assemblage from Mission Espíritu Santo de Zuñiga (41VT11), Victoria County, TX. Unpublished Masters Thesis, The University of Texas at Austin.

Lane, A.

1970 French Faience. Faber and Faber Ltd. London, England.

Leutenegger, B. (translator)

1976 Guidelines for a Texas Mission: Instructions for the Missionary of Mission Concepción in San Antonio. Old Spanish Missions Historical Research Library at San José Mission, San Antonio.

Leutenegger, B., and C. Perry

1976 The Establishment of the Missions and the Work of the Missionary Fathers. In San Antonio in the Eighteenth Century, by the San Antonio Bicentennial Heritage Committee, pp. 22-34. Clarke Printing, San Antonio.

Lister, F.C. and R.H. Lister

1974 Maiolica in Colonial Spanish America. Historical Archaeology 8:17-52.

1975 Non-Indian Ceramics from the Mexcio City Subway. El Palacio 81(2):25-48. 
1976a Distribution of Mexican Majolica along the Northern Borderlands. In Collected Papers in Honor of Marjorie Ferguson Lambert. Edited by A. H. Schroeder. Papers of the Archaeological Society of New Mexico No. 3 pp. 113-40, Albuquerque.

1976b A Descriptive Dictionary for 500 Years of Spanish-Tradition Ceramics (13th Through 18th Centuries). Special Publication No. 1, Society for Historic Archaeology.

1987 Andalusian Ceramics in Spain and New Spain: A Cultural Register from the Third Century B. C. to 1700. University of Arizona Press, Tucson.

Longoria, L. D.

2007 Chinese Export Porcelain in the Missions and Presidios of Eighteenth Century Spanish Texas. Unpublished Master's Thesis. Department of Anthropology, The University of Texas at San Antonio.

Marken, M.W.

1994 Pottery from Spanish Shipwrecks 1500-1800. University of Florida Press, Gainesville.

May, R.V.

1975 Mexican Majolica in Northern New Spain: A Model for Interpreting Ceramic Change. Unpublished Masters Thesis, San Diego State University.

McDonald, D.R.

2002 Mission History. In Archaeological Investigations at the Last Spanish Colonial Mission Established on the Texas Frontier: Nuestra Señora de Refugio (41RF1), Refugio County, Texas. Volume I: Archaeological Investigations, by C.L. Tennis, pp. 7-68. Archeological Studies Program Report No. 39, Environmental Affairs Division, Texas Department of Transportation, Austin, and Archaeological Survey Report No. 315, Center for Archaeological Research, The University of Texas at San Antonio.

McEwan, B. G., ed.

1993 The Spanish Missions of La Florida. University Press of Florida, Gainsville.

McKenzie, C.M.M.

1989 Independent Study Report on Guanajuato Majolica in the San Antonio Missions Area. Unpublished manuscript on file at the Center for Archaeological Research, The University of Texas at San Antonio.

Meissner, B.A.

1996 The Alamo Restoration and Conservation Project: Excavations at the South Transept. Archaeological Survey Report No. 245. Center for Archaeological Research, The University of Texas at San Antonio.

1999 Vertebrate Faunal Remains. In Archaeological Investigation of Rainwater Catchment Basins Along the South Wall of Mission San José, San Antonio, Texas, by S.A. Tomka and A.A. Fox, pp. 39-46. Archaeological Survey Report No. 287. Center for Archaeological Research, The University of Texas at San Antonio.

2000 Vertebrate Faunal Remains. In Archaeological Excavations of the Priest Quarters, Mission San Francisco de la Espada, 41BX4, San Antonio, Texas, by J.E. Zapata, M.J. Brown, and J.J. Durst. Archaeological Survey Report No. 295, Center for Archaeological Research, The University of Texas at San Antonio. Pp. 47-60. 
Moorehead, M.L.

1975 The Presidio: Bastion of the Spanish Borderlands. University of Oklahoma Press, Norman.

Nickels, D. L.

20001999 Excavations at Mission Rosario. Archaeological Survey Report No. 298. Center for Archaeological Research, The University of Texas at San Antonio.

Parkes, H.B.

1938 A History of Mexico. Houghton Mifflin Company, Boston.

Poole, S.

1965 War by Fire and Blood: The Church and the Chichimecas, 1585. The Americas 22:115-37.

Richards, H.C.

1936 The Establishment of the Candelaria and San Lorenzo Missions on the Upper Nueces. Unpublished Masters Thesis. The University of Texas at Austin.

Ricklis, R.A.

1996 The Karankawa Indians of Texas: An Ecological Study of Cultural Tradition and Change. University of Texas Press, Austin.

Ricklis, R.A., S.D. deFrance, and B. Albert

2000 Archeological investigations at the Spanish colonial missions of Espiritu Santo (41GD1) and Nuestra Señora del Rosario (41GD2), Goliad County, Texas. Coastal Archaeological Studies, Inc., Corpus Christi.

Rice, P. M.

1987 Pottery Analysis: A Sourcebook. The University of Chicago Press, Chicago.

Rishel, J. J., and S. L. Stratton

2006 The Arts in Latin America, 1492-1820. Philadelphia Museum of Art, fall 2006. Los Angeles County Museum of Art, 2007. Yale University Press, New England.

Roell, C.H.

1996 Nuestra Señora de Loreto Presidio. In The New Handbook of Texas, edited by R. Tyler. Vol. 4:1067-1069. Texas State Historical Association, Austin.

Schoelwer, S.P.

2006 San Antonio de Valero Mission. The Handbook of Texas Online. April 18, 2006. www.tsha.utexas.edu/handbook/online/articles/SS/uqs8.html. .

Schuetz, M.K.

1968 The History and Archaeology of Mission San Juan Capistrano, San Antonio, Texas. Volume 1. Archeological Program Report Number 10. State Building Commission, Austin.

1969 The History and Archaeology of Mission San Juan Capistrano, San Antonio, Texas. Volume 2. Archeological Program Report Number 11. State Building Commission, Austin.

1973 Archaeological Investigations at Mission San Antonio de Valero, the Second Patio. Unpublished manuscript on file. Office of the State Archeologist, Texas Historical Commission, Austin. 
1980 The History and Archeology of Mission San Juan de Capistrano, San Antonio, Texas: Excavation of the Convento. Unpublished manuscript on file. Office of the State Archeologist, Texas Historical Commission, Austin.

Scurlock, D., A. Benavides, Jr., D. Isham, and J.W. Clark Jr.

1976 An Archeological and Historical Survey of the Proposed Mission Parkway, San Antonio, Texas. Office of the State Archeologist, Texas Historical Commission, Austin.

Seifert, D.

1977 Archaeological majolicas of the rural Teotihuacán Valley, Mexico. Ph.D. dissertation, University of Iowa; University Microfilms. Ann Arbor.

Smith, H.G.

1965 Archaeological Excavations at San Rosa Pensacola. Notes in Anthropology No. 10, Department of Anthropology, Florida State University, Tallahassee.

Snow, D.H.

1965 The Chronological Position of Mexican Majolica in the Southwest. El Palacio 72(2):25-35.

Tennis, C.L.

2002 Archaeological Investigations at the last Spanish Colonial mission established on the Texas Frontier: Nuestra Señora del Refugio, Refugio County, Texas. Two volumes. Archeological Studies Program Report No. 39. Texas Department of Transportation Environmental Affairs Division, Austin and Archaeological Survey Report No. 315. Center for Archaeological Research, The University of Texas at San Antonio.

Timmons, W.H.

1996 San Elizario Presidio. In The New Handbook of Texas, edited by R. Tyler, Vol. 5:838-839. Texas State Historical Association, Austin.

Tomka, S.A., and A.A. Fox

1998 Mission San José Indian Quarters Wall Base Project, Bexar County, Texas: with appendixes on the monitoring of the San José bus drive and granary parking lot, and on the monitoring and shovel testing of the San José service drive. Archaeological Survey Report No. 278. Center for Archaeological Research, The University of Texas at San Antonio.

Tous, G. (translator)

1930 The Espinosa-Olivares-Aguirre Expedition of 1709. Preliminary Studies of the Texas Catholic Historical Society Vol. 1 No. 3

Tunnel, C.

1966 A Description of Enameled Earthenware from an Archeological Excavation and Mission San Antonio de Valero (the Alamo). Archeological Program Report No. 2. Texas State Building Commission, Austin.

Tunnell, C.D., and J.R. Ambler

1967 Archeological excavations at Presidio San Agustín de Ahumada. Archeological Program, Report No. 6. Texas State Building Commission. Austin. 
Tunnell, C.D. and W.W. Newcomb, Jr.

1969 A Lipan Apache Mission, San Lorenzo de la Santa Cruz, 1762-1771. Bulletin of the Texas Memorial Museum 14. Texas Memorial Museum, Austin.

Ulrich, K.

2004 Merging Cultures: A Comparison of Native and Colonial Ceramics from Mission San Juan de Capistrano, San Antonio, Texas. Unpublished Master's Thesis. Department of Anthropology, The University of Texas at San Antonio.

Walter, T., S. Dial, and V.K. Hindes

2006a Reinterpreting Mission History: The 2nd Location of Espíritu Santo at "Tonkawa Bank" Texas Beyond History. Available online at http://www.texasbeyondhistory.net/espiritu/reinterpret.html. Accessed January 31, 2007

2006b The Mission in Its Final Location. Texas Beyond History. Accessed January 31, 2007. Available online at http://www.texasbeyondhistory.net/espiritu/goliad.html.

Walthall, J.A.

1991 Faience in French Colonial Illinois. Historical Archaeology 25(1):80-105.

Waselkov, G.A. and J.A. Walthall

2002 Faience Styles in the French North America: A Revised Classification. Historical Archaeology 36(1):62-78.

Weber, D. J.

1992 The Spanish Frontier in North America. Yale University Press, New Haven and London.

West, E.H. (translator)

1916 Itinerary of the de León Expedition of 1689. In Spanish Exploration in the Southwest, 1542-1706, edited by H. E. Bolton, pp. 388-404. Charles Scribner's Sons, New York.

Wooster, R.

1996 Nuestra Señora de la Luz Mission. In The New Handbook of Texas, edited by R. Tyler. Vol. 4:1069. Texas State Historical Association, Austin.

Wright, R.E.

2001 Spanish Missions. Handbook of Texas Online. Accessed January 30, 2007. Available at http://www.tsha.utexas.edu/handbook/online/articles/SS/its2.html. 


\section{APPENDIX A: GLOSSARY OF TERMS USED IN CERAMIC ANALYSIS}

This glossary is limited to words commonly used in ceramic analyses in Texas and is based on a much more comprehensive glossary in Rice (1987:471-485). Words in definitions that are also defined in this glossary are in italics.

ADDITIVE: an organic or mineral material mixed with a clay by the potter to modify its properties in forming, drying and firing. Often used interchangeably with temper.

ATMOSPHERE (KILN): the gases in the air in the environment of heating and cooling clay, particularly with reference to the availability of oxygen; see also oxidation, reduction.

BASE: The underside of a vessel, sometimes called the foot.

BISCUIT (BISQUE): unglazed fired pottery; the first firing of a ware that is subsequently glazed and refired.

BODY: 1) a clay mixture suitable for forming vessels or that has been fired into a vessel, often used interchangeably with fabric or paste; 2) that portion of a ceramic vessel between the orifice and the base.

BURNISH: a method of producing a luster on an unfired clay surface by rubbing it while leather-hard with a hard, smooth surface to compact and align the surface particles.

CERAMICS (OR CERAMIC): 1)Materials manufactured of silicates and hardened by application of heat; 2) The research and applied fields developed around ceramic products; 3)The art or technique of producing articles by applying heat to inorganic and nonmetallic materials, usually clays.

CLAY: 1) one of several hydrous alumina-silicate minerals that are formed by the decomposition of rock, chiefly granite and have the property of plasticity; 2) an extremely fine particle size grade, less than 0.002 $\mathrm{mm}$ in diameter; 3) soil composed of 35\%-40\% particles less than $0.002 \mathrm{~mm}$ in diameter; 4) a finegrained material that becomes plastic when wet and hardens permanently with the application of heat.

COILING: the method of hand-building an object of clay by successive additions of ropes or coils of clay.

COIL FRACTURE: A smooth-edged circumferential breakage characteristic of coiled vessels in which the coils were poorly bonded, resulting in planes of weakness.

COLORANT: A chemical element that contributes color to a mixture; unglazed, low-fired pottery is colored chiefly by carbon, iron, and manganese, whereas a broader range of colors occurs in glazes. 
CORE: a black or gray zone in the interior cross section of a vessel wall. Usually associated with incomplete removal of carbonaceous matter from the clay during relatively low-temperature firing.

CRAZING: a defect characterized by a fine network of cracks in the glaze, occurring when the glaze is in tension because it shrinks more that the body.

CRITICAL POINT: The point in the drying of a clay article at which shrinkage has largely ceased and the piece is rigid and leather-hard; also referred to as the critical moisture content.

DOCKING: Soaking a freshly fired article in cold water for a short period to prevent or reduce spalling of the ware if it contains calcareous inclusions.

EARTHENWARE: A glazed or unglazed nonvitreous ceramic material, usually low fired, porous, and permeable, and red or brown in color.

FABRIC: the composition of a fired ceramic, including clay, inclusions, and pores, excluding surface treatment; often used synonymously with paste and body.

FAIENCE: French term for earthenware with an opaque tin-lead glaze.

FIRE: To heat a ceramic material in order to permanently harden it. The composition of the clay, the temperature and length of time at which it is fired, the uniformity of the heat, and the presence or absence of oxygen in the atmosphere around the vessel all affect the outcome of firing.

FIREBOX: A combustion chamber of a kiln (usually one fired by wood), typically beneath the ware chamber.

FIRECLOUD: A darkened area on a vessel's surface resulting from uneven firing and the deposit of carbon in the pores during firing, characteristic of firings in which fuel and vessels are in immediate proximity.

FLUX: A substance in a clay body, slip, or glaze that lowers the melting point of the mixture and promotes vitrification.

FOOT: The base of a ceramic vessel, usually a ring-like projection formed by tooling or by adding a coil.

GLASS: A silicate mixture that has been heated to a melt and then cooled to a solid without crystallizing. 
GLAZE: A glassy coating melted onto the surface of a ceramic article, applied as a liquid suspension to a ware that has usually been fired once and is subsequently re-fired.

GREEN: Formed but unfired ceramic articles; used as greenware, green strength, etc.

GROG: Pre-fired clay (or potsherds) crushed or ground to small particle size and added to a clay as a type of temper to modify its properties.

INCLUSION: Particulate matter, usually mineral in nature, present in clay or fabric, either naturally or added by the potter; often used synonymously with temper.

KILN: An enclosed or partially enclosed construction for firing ceramic materials. Kilns may be labeled on the basis of the characteristics of construction or by their firing characteristics. Some important types of kilns include: clamp (open-topped updraft kiln, of semi-permanent construction, usually intermixed with fuel and ware); climbing (kiln set along a slope to aid the draft; downdraft (an enclosed periodic kiln in which the heat passed to the top of the kiln, then the draft carries it down through the ware); muffle (a kiln constructed so that the ware is not directly subjected to the radiant heat from the flame or heating elements); pit (a clamp that is excavated partially into the ground); and updraft (a kiln in which the heat or flame passes upward through the ware and then is vented outside).

LEATHER-HARD: Clay that is dried to the critical point so that individual clay particles touch and the body is rigid but retaining sufficient moisture to be carved, burnished, or joined.

LIP: The edge or margin of the orifice of a vessel; sometimes refers more specifically to a modification of a rim of a vessel for pouring.

MAJOLICA (MAIOLICA): Earthenware covered with an opaque tin-lead glaze, best known from fifteenthto nineteenth-century Europe. The name comes from the island of Majorca, from which Italy obtained these wares in trade, but the term is commonly used as a technological class without reference to origins of the ware. Delft ware and faience are two types of tin-lead glazed earthenwares that fall under the rubric majolica.

MINERAL: A homogenous, inorganic, naturally occurring solid with a characteristic chemical composition and a regularly ordered atomic structure.

NECK: The part of a vessel between the shoulder and the rim, typically characterized by a marked constriction of the maximum body diameter. If there is little constriction, the region is called the collar. 
NONPLASTIC: Lacking the property of plasticity; material inclusions that reduce the plasticity and stickiness of the clay; see also additive, temper.

ORIFICE: The mouth or opening of a vessel.

OXIDATION: The combining of an atom or ion with oxygen, usually resulting in the loss of electrons; a firing atmosphere characterized by an abundance of free oxygen, which combines with elements (such as iron) in the body and yields clear colors of the ceramic body; see also reduction.

PARTING AGENT: A material such as sand, ash, or dry clay, sprinkled over a mold or working surface to prevent wet clay from sticking; sometimes refers to wax spread over metal.

PASTE: A clay or mixture of clay and added materials, often used synonymously with fabric, body, or ware. Technically paste differs from fabric because it does not include pores and differs from ware because it excludes surface treatment.

PIGMENT: A coloring material, usually a mixture of colorants, clay, water and a binder; may be organic or inorganic.

PLASTICITY: The property of a material that enables it to be shaped when wet and to hold this shape when the shaping force is removed.

PORCELAIN: A fine, vitrified, high-fired ceramic body, usually translucent and white.

POROSITY: The volume of pores contained within a solid, such as a ceramic object.

POTTERY: Low-fired, non-vitrified objects including cooking, serving, and storage vessels (as distinct from high-fired ceramics).

RILLING: The spiral ridges or striations around the interior or exterior of a vessel thrown on a wheel, formed by finger pressure in "lifting" the clay; also called throwing marks.

RIM: The area between the lip or margin and the side wall or neck of a vessel; sometimes used interchangeably with lip, especially if there is no change in orientation between the lip and neck or wall.

RING BUILDING: A type of coiling in which individual coils or annular rings are placed as separate "courses" to build up a vessel. 
SAND: A particle size grade ranging from $2 \mathrm{~mm}$ to $0.05 \mathrm{~mm}$ in diameter.

SHERD (POTSHERD, SHARD): A term archaeologists use to refer to a broken fragment of pottery.

SHOULDER: The upper part of the body or a restricted vessel; that portion between the maximum diameter and the neck.

SILICATE: A compound in which $\mathrm{SiO}_{4}$ tetrahedrons are major constituents. Clays, for example are alumina-silicates in which tetrahedrons are joined primarily in sheets.

SILT: A particle size grade in which particles are between 0.05 and $0.002 \mathrm{~mm}$ in diameter; a sediment consisting of $80 \%$ or more silt-sized particles and less than $12 \%$ clay-sized particles.

SLIP: A fluid suspension of fine clay and water, used to coat a body before firing or poured into a mold to cast a piece; a non-vitreous coating on a pottery vessel.

TEMPER: To mix or modify to a proper consistency; a material-mineral or organic, but usually nonplastic - added to a clay to improve its working, drying, or firing properties; see also additive, inclusion, nonplastic.

TERRA COTTA: an unglazed earthenware body, usually red, with a relatively coarse, low-fired paste.

TEXTURE: the general character of a fired fabric as viewed in cross section, described in terms of particle size (fine vs. coarse), characteristics of fracture (friable, blocky), and density (dense vs. porous).

THIN SECTION: a piece of ceramic ground to $0.03 \mathrm{~mm}$ or less, mounted between glass slides, usually for study under a microscope.

THROAT: the point of maximum restriction of the diameter of the neck or collar of a vessel.

THROW: to form a ceramic object on a potter's wheel, making use of the centrifugal force produced by rapid motion of the wheel.

UNDERGLAZE: a type of colored decoration applied to either unfired or biscuit ware before the glaze is applied and the vessel re-fired.

VITRIFICATION: the action or process of becoming glass; the fusing of particles in a clay body during high-temperature firing to become a homogenous mass. 
WARE: 1) a class of pottery whose members share a similar technology, fabric, and surface treatment; 2) a ceramic material (e.g. greenware, earthenware, stoneware, etc.)

WHEEL: a device capable of sustained rotation with a flat surface on which a potter builds a vessel. 


\section{APPENDIX B \\ Bibliography of Archaeological ReSEarch at SPANiSh Colonial Sites IN TEXAS \\ BARBARA A. MEISSNER}

The following bibliography is as comprehensive as possible; however it does not claim to contain a reference for every published archaeological report on Spanish Colonial sites in Texas. It is likely that there may be more publications of which we are unaware, but the search for references was as thorough as could be. Several of the mission and presidio sites have not undergone archaeological testing or investigations. In these instances, a reference that would include historical background and/or a possible location may be listed. Analyses of materials from the colonial sites that are not part of archaeological site reports are included when readily available. We have included a few unpublished excavation reports and artifact analyses, most of which are Masters Theses that are readily available. Most of the rest of the unpublished reports are available upon request from the Center for Archaeological Research.

Each different location is considered separately, so that there may be several listings of the same name when a mission was moved several times without changing its name. Sites whose locations are not known (such as the first sites of San Antonio de Valero and Nuestra Señora del Espíritu Santo) are not listed. Mission sites are listed first, then presidios and settlements, in roughly geographic order from west to east. The archaeological site number assigned by the UT- TARL is included, when appropriate. Publications that cover more than one site are listed under each site.

The intensity of Spanish occupation at San Antonio presents a challenge to this system. Six missions, some of which had several locations, the presidio, also with several locations, the Villa San Fernando, and the acequia system that connected them all are encompassed within a few miles of each other in what is now downtown San Antonio. References to work done specifically at the missions and the presidio are listed under those names. For simplicity, all other work on Colonial period sites in San Antonio is listed under Villa de San Fernando, in the Settlements section, even when the site in question is outside of Villa San Fernando itself. All work done on acequias, except that done in the immediate vicinity of a mission site, is also included in the Villa San Fernando section. 


\section{MISSION SiTES}

\section{CORPus CHRISTI DE LA ISLETA DEL SUR (41EP39)}

Batcho, D.G., M.G. Canavan, B. Kauffman, and D. Sick

1989 Historical Documentation, Archival Research, and Cultural Resources Evaluation at eh Site of the Proposed Ysleta Health Clinic and W.I.C. Facility in the City of El Paso, Texas. Cultural Resources Report Number 95. Batcho \& Kauffman Associates, Las Cruces.

Decorme, G.S.J.

n.d. Las Misiones de Ysleta, Socorro y San Elizario. Unpublished Manuscript in the El Paso Public Library, El Paso.

Gerald, R.E.

1990 Missions, Presidios, Haciendas, and Caminos of the Paso Del Norte Area. The Artifact 28(3):4158.

Kauffman, B., D.G. Batcho, and M.G. Canavan

1990 Results of Subsurface Survey and a Data Recovery Plan for Mitigation of Impact at the Ysleta Neighborhood Clinic and W.I.C. Facility Site. Cultural Resources Report 98. Batcho \& Kauffman Associates, Las Cruces.

Leach, J.D., N.P. Houser, R.D. Harrison, J.A. Peterson, and R.P. Mauldin

1996 Living on the River's Edge. Volume I: Archaeological Test Excavations at Ysleta de Sur Pueblo, Texas. Archaeological Research, Inc., El Paso.

Leach, J.D. and J.A. Peterson

1995 Test Excavations at Tigua Ysleta del Sur Pueblo. Cultural Resource Management: News and Views, 8(1):21.

Morrow, H.C.

1981 The Mission Trail: History, Architecture, Cultural Heritage, and Historic Preservation of the Lower Valley of El Paso, Texas. A Historic Preservation Plan. West Texas Council of Governments, El Paso.

1984 Vineyards and Irrigation: Land Use and Social Customs, Spanish Colonial to the Early American Period in the El Paso-Cuidad Juarez Valley. Paper presented in the Annual Meeting of the New Mexico Historical Society, Taos.

1989 Documents Relating to a Mission Trail National Register Nomination. 5 Volumes. Unpublished Report, El Paso.

Peterson, J.A. and D.O. Brown (editors)

1994 El Valle Bajo: The Culture History of the Lower Rio Grande Valley of El Paso. Archaeological Research, Inc. El Paso. Hicks and Company, Austin. 


\section{SAN ANTONIO DE SENECÚ DEL SUR}

Gerald, R.E.

1990 Missions, Presidios, Haciendas, and Caminos of the Paso Del Norte Area. The Artifact. 28(3):41-58.

\section{SAN LORENZO}

Tunnell, C.D., and W.W. Newcomb

1969 A Lipan Apache mission: San Lorenzo de la Santa Cruz, 1762-1771. Bulletin of the Texas Memorial Museum, No. 14. Texas Memorial Museum, Austin.

\section{Nuestra SEÑORA DE LA LiMPIa CONCEPCIÓN DE LOS}

Habig, M.A.

1990 Spanish Texas Pilgrimage: The Old Franciscan Missions and Other Spanish Settlements of Texas 1632-1821. Franciscan Herald Press, Chicago.

\section{PIROS DE SOCORRO DEL SUR (41EP1538)}

Decorme, G.S.J.

n.d. Misión de Nuestra Señora de la Limpia Concepción de los Piros de Socorro. Unpublished Manuscript in the El Paso Public Library, El Paso.

Evans, C.T.

1988 An Analysis of Burials from the Old Socorro Mission, Socorro, Texas. Unpublished Masters Thesis. New Mexico State University, Las Cruces.

George, E.

1980 Nuestra Señora de La Purísima Concepción del Socorro. Unpublished report for the Mission Heritage Association, El Paso.

Gerald, R.E.

1982/3 The Old Socorro Mission Site. Preliminary Report. Department of Sociology and Anthropology, University of Texas at El Paso.

1990 Missions, Presidios, Haciendas, and Caminos of the Paso Del Norte Area. The Artifact. 28(3):41-58.

1990 The Old Socorro Mission Site Test Excavations. The Artifact 28:3. 
Peterson, J.A. and D.O. Brown (editors)

1994 El Valle Bajo: The Culture History of the Lower Rio Grande Valley of El Paso. 3 Volumes. Archaeological Research, Inc. El Paso. Hicks and Company, Austin.

Peterson, J.A., D.O. Brown, and D. Anthony (editors)

1992 Archaeological Survey of the Socorro Mission and Mesa Verde Neighborhoods, El Paso County, Texas. Report Prepared for the City of Socorro by Archaeological Research, Inc., Hicks and Company, Austin.

Peterson, J.A., R.A. Lopez, D.O. Brown, and K. Weedman (editors)

1994 Cultural Resources Survey in Socorro and San Elizario El Paso County, Texas Phase III Architectural Studies-San Elizario. Hicks and Company, Austin.

Rowland, T.A.

1984 The Search for the Old Socorro Mission. Unpublished M.A. Thesis. Department of Anthropology, University of Texas at El Paso.

Schuetz, M.K.

1980 The Archaeology of Mission Socorro. The Artifact 18(2):1-34.

Tice, B.W.

1987 A Description of Plainware Rim Sherds from the Old Socorro Mission Site. Unpublished Masters Thesis. Department of Anthropology, University of Texas at El Paso.

Weedman, K., D.O. Brown, and J.A. Peterson

1994 Cultural Resource Survey in Socorro and San Elizario El Paso County, Texas Phase III Archaeological Investigations-Socorro. Hicks and Company, Austin.

\section{SANTA MARÍA DE LAS CALDAS}

Gerald, R.E.

1990 Missions, Presidios, Haciendas, and Caminos of the Paso Del Norte Area. The Artifact. 28(3):4158.

\section{LA NAVIDAD EN LAS CRUCES}

Applegate, H.G. and C.W. Hansella

1974 La Junta de los Rios del Norte y Conchos. Southwestern Studies 41. Texas Western Press,. El Paso.

Habig, M.A.

1990 Spanish Texas Pilgrimage: The Old Franciscan Missions and Other Spanish Settlements of Texas 1632-1821. Franciscan Herald Press, Chicago. 


\section{El ApÓSTOL SANTIAGO}

Applegate, H.G. and C.W. Hanselka

1974 La Junta de los Rios del Norte y Conchos. Southwestern Studies 41. Texas Western Press, El Paso.

Habig, M.A.

1990 Spanish Texas Pilgrimage: The Old Franciscan Missions and Other Spanish Settlements of Texas 1632-1821. Franciscan Herald Press, Chicago.

\section{SAn ANTONio De los PuliQues}

Applegate, H.G. and C.W. Hanselka

1974 La Junta de los Rios del Norte y Conchos. Southwestern Studies 41. Texas Western Press, El Paso.

Habig, M.A.

1990 Spanish Texas Pilgrimage: The Old Franciscan Missions and Other Spanish Settlements of Texas 1632-1821. Franciscan Herald Press, Chicago.

\section{SAN CRISTÓBAL}

Applegate, H.G. and C.W. Hanselka

1974 La Junta de los Rios del Norte y Conchos. Southwestern Studies 41. Texas Western Press, El Paso.

Habig, M.A.

1990 Spanish Texas Pilgrimage: The Old Franciscan Missions and Other Spanish Settlements of Texas 1632-1821. Franciscan Herald Press, Chicago.

\section{SANTA MARÍA DE LA REDONDA DE LOS CíBOLOS}

Applegate, H.G. and C.W. Hanselka

1974 La Junta de los Rios del Norte y Conchos. Southwestern Studies 41. Texas Western Press, El Paso.

Habig, M.A.

1990 Spanish Texas Pilgrimage: The Old Franciscan Missions and Other Spanish Settlements of Texas 1632-1821. Franciscan Herald Press, Chicago. 


\section{SAN CLEMENTE}

Habig, M.A.

1990 Spanish Texas Pilgrimage: The Old Franciscan Missions and Other Spanish Settlements of Texas 1632-1821. Franciscan Herald Press, Chicago.

\section{SANTA CRUZ DE SAN SABÁ}

Carlson, S.B.

1991 The Search for San Sabá: An Apache Mission on the San Saba River, Menard County, Texas. Center for Historic Resources, Texas A\&M University, College Station.

Gilmore, K.K.

1967 A Documentary and Archeological Investigation of Presidio San Luis de las Amarillas and Mission Santa Cruz de San Sabá, Menard County, Texas. Archeological Program Report No. 9. State Building Commission, Austin.

Hall, G.D.

1994 Searching for San Sabá. Heritage 12.

Hindes, V.K., M.R. Wolf, G.D. Hall, and K.K. Gilmore

1995 The Rediscovery of Santa Cruz de San Sabá, a Mission for the Apache in Spanish Texas. Texas Historical Foundation and Texas Tech University, Lubbock.

Walter, T.L.

2003 Ruin of ruins: archaeological excavations at Presidio San Sabá, 41MN1, Menard County, Texas; 2000-2002 field seasons. San Saba Regional Survey Report 2. Texas Tech Archeological Laboratory, Lubbock.

\section{SAN LORENZO DEL LA SANTA CRUZ}

Richards, H.C.

1936 The Establishment of the Candelaria and San Lorenzo Missions of the Upper Nueces. Unpublished Masters Thesis. The University of Texas at Austin.

Tunnell, C.D., and W.W. Newcomb, Jr.

1967 A Lipan Apache Mission, San Lorenzo de la Santa Cruz, 1762-1777. Texas Memorial Museum, Austin. 


\section{Mission NuESTRA SEÑORA DE LA CANDELARIA DEL CAÑÓN}

Richards, H.C.

1936 The Establishment of the Candelaria and San Lorenzo Missions of the Upper Nueces. Unpublished Masters Thesis. The University of Texas at Austin.

Texas Beyond History

2007 Mission Nuestra Señora de la Candelaria del Cañon. Texas Beyond History website. Accessed August 6, 2007. http://www.texasbeyondhistory.net/plateaus/images/he1.html. .

Tunnell, C.D., and W.W. Newcomb, Jr.

1967 A Lipan Apache Mission, San Lorenzo de la Santa Cruz, 1762-1777. Texas Memorial Museum, Austin.

\section{SAN FranCISCO XAVIER ON THE GUADALUPE}

Gilmore, K.K.

1969 The San Xavier Missions: A Study in Historical Site Identification. Report 16. Texas State Building Commission, Austin.

\section{SAN ANTONIO DE VALERO (41BX6)}

Briggs, A.K.

1993 Archeological Testing, Trenching and Excavations for the Alamo Sales Museum Expansion Project at the Alamo Shrine and Museum (Mission San Antonio de Valero), in San Antonio, Bexar County, Texas. Unpublished manuscript on file at the Library of the Daughters of the Republic of Texas, San Antonio.

Eaton, J.D.

1980 Excavations at the Alamo Shrine (Mission San Antonio de Valero). Special Report No. 10. Center for Archaeological Research, The University of Texas at San Antonio.

Fox, A.A. (editor)

1992 Archaeological Investigations in Alamo Plaza, San Antonio, Bexar County, Texas 1988 and 1989. Archaeological Survey Report No. 205. Center for Archaeological Research, The University of Texas at San Antonio.

Fox, A.A., and T.R.. Hester.

1976 The Archaeology and History of Alamo Plaza. Archaeological Survey Report No. 16. Center for Archaeological Research, The University of Texas at San Antonio. 
Fox, A.A. and J.E. Ivey

1979 Historical Survey of the Lands within the Alamo Plaza-River Linkage Development Project. Archaeological Survey Report No. 77. Center for Archaeological Research, The University of Texas at San Antonio.

Greer, J.W.

1967 A Description of the Stratigraphy, Features and Artifacts from an Archeological Excavation at the Alamo. Archeological Program Report No. 3. State Building Commission, Austin.

Guderjan, T.J.

2005 Excavations at the Alamo (41BX6) 1995 "Alamo Well" Project: Final Report Submitted to the Texas Antiquities Commission. St. Mary’s University, San Antonio.

Gunn, J., A.A. Fox, H.G. Uecker, and I.W. Cox

1989 Alamo Excavations 1989-South Defense. Unpublished manuscript on file at Center for Archaeological Research, The University of Texas at San Antonio.

Ivey, J.E.

1989 Excavations of the West Wall of the Alamo. Preliminary draft on file at the Center for Archaeological Research, The University of Texas at San Antonio.

Ivey, J.E. and A.A. Fox

1997 Archaeological and Historical Investigations at the Alamo North Wall, San Antonio, Bexar County, Texas. Archaeological Survey Report No. 224. Center for Archaeological Research, The University of Texas at San Antonio.

Meissner, B.A.

1996 The Alamo Restoration and Conservation Project: Excavations at the South Transept. Archaeological Survey Report No. 245. Center for Archaeological Research, The University of Texas at San Antonio.

1998 Analysis of Vertebrate Faunal Remains from a Spanish Colonial Mission, San Antonio de Valero (the Alamo), Bexar County, Texas. Unpublished Master's Thesis, College of Behavioral and Cultural Sciences, The University of Texas at San Antonio.

1999 Analysis of Vertebrate Faunal Remains from a Spanish Colonial Deposit at Mission San Antonio de Valero (the Alamo). Bulletin of the Texas Archeological Society 70:281-313.

Nickels, D.L.

1999 An Archaeological Assessment of the Drainage Improvement Area on the Northeast Side of Alamo Hall, and Home of Former Mayor Wilhelm Thielepape (41BX507), San Antonio, Texas. Archaeological Survey Report No. 244. Center for Archaeological Research, The University of Texas San Antonio.

Schuetz, M.K.

1973 Archeological Investigations at Mission San Antonio de Valero: The Second Patio. Unpublished manuscript on file at the Center for Archaeological Research, The University of Texas at San Antonio. 
Sorrow, W.M.

1972 Archeological Salvage Excavations at the Alamo (Mission San Antonio de Valero) 1970. Research Report No. 4. Texas Archeological Salvage Project, The University of Texas at Austin.

Tunnell, C.D.

1966 A Description of Enameled Earthenware from an Archeological Excavation at Mission San Antonio de Valero. Archeological Program Report No. 2. State Building Commission, Austin.

\section{SAN FRANCISCO XAVIER DE NÁJERA (41BX12)}

(Note: Mission Concepción built on same site)

Ivey, J.E. and A.A. Fox

1999 Archaeological Investigations at Mission Concepción and Mission Parkway. Archaeological Survey Report No. 114. Center for Archaeological Research, The University of Texas at San Antonio.

Meissner, B.A.

2001 Concepción. In Archaeological Investigations at Four San Antonio Missions: Mission Trails Underground Conversion Project, edited by C. L. Tennis, pp.63-105. Archaeological Survey Report No. 297. Center for Archaeological Research, The University of Texas at San Antonio.

Mission Nuestra SEÑora de la Purísima CONCEPCión de ACuÑa (41BX12)

Brown, M.J., A.A. Fox, and B.A. Meissner

1994 Archaeological Testing for the Mission Road Realignment Project, Phase II, at Mission Concepción, San Antonio, Texas. Archaeological Survey Report No. 222. Center for Archaeological Research, The University of Texas at San Antonio.

Cook, P.

1980 A Review of the History and Archaeology of Mission Concepción. La Tierra 7(3):3-16.

Fox, A.A.

1988 Archaeological investigations at Mission Concepción, fall of 1986. Archaeological Survey Report No. 172. Center for Archaeological Research, The University of Texas at San Antonio.

1989 Monitoring of Utility trenches at Mission Concepción, San Antonio, Texas. Archaeological Survey Report No. 180. Center for Archaeological Research, The University of Texas at San Antonio.

1992 Archaeological investigation to locate the northwest corner of Mission Concepción, San Antonio, Bexar County, Texas. Archaeological Survey Report No. 212. Center for Archaeological Research, The University of Texas at San Antonio. 
Ivey, J.E. and A.A. Fox

1999 Archaeological Investigations at Mission Concepción and Mission Parkway. Archaeological Survey Report No. 114. Center for Archaeological Research, The University of Texas at San Antonio.

Krueger, M., and F.K. Meskill

1992 Test Excavations at Mission Concepción Courtyard, San Antonio, Bexar County, Texas. Archaeological Survey Report No. 214. Center for Archaeological Research, The University of Texas at San Antonio.

Labadie, J.H.

1989 Archaeological and Historical Investigations for the Mission Road Realignment Project, San Antonio, Texas. Archaeological Survey Report No. 173. Center for Archaeological Research, The University of Texas at San Antonio.

Meissner, B.A.

2001 Concepción. In Archaeological Investigations at Four San Antonio Missions: Mission Trails Underground Conversion Project, edited by C.L. Tennis, pp.63-105. Archaeological Survey Report No. 297. Center for Archaeological Research, The University of Texas at San Antonio.

Miller, K.H. and B.A. Meissner

2001 Archaeological Testing in the Mission Concepción Courtyard (41BX12), San Antonio, Texas. Archaeological Survey Report No. 304. Center for Archaeological Research, University of Texas at San Antonio.

Robinson, R.C.

2001 Monitoring Electrical Conduit Trenching at Mission Concepción. In Archaeological Investigations at Four San Antonio Missions: Mission Trails Underground Conversion Project, edited by C.L. Tennis, pp.106-110. Archaeological Survey Report No. 297. Center for Archaeological Research, The University of Texas at San Antonio.

Scurlock, D. and D.E. Fox.

1977 An Archeological Investigation of Mission Concepción, San Antonio, Texas. Office of the State Archeologist Report No. 28. Texas Historical Commission, Austin.

Scurlock, D. and T.P. Powers, Jr.

1975 Interim Report for Mission Concepción (Archaeological Investigations), San Antonio, Bexar County, Texas. Office of the State Archaeologist, Special Report 7. Texas Historical Commission, Austin.

\section{SAN José Y SAN Miguel De AgUAYo (41BX3)}

Clark, J.W.

1978 Mission San José y San Miguel de Aguayo: Archaeological Investigations, December 1974. Archaeological Report No. 29, Texas Historical Commission, Austin. 
Clark, J.W., and E.R. Prewitt.

1979 Archeological Test Excavations in Areas to be Affected by a Proposed French Drain West of the Granary, Mission San Jose State Historic site (41BX3), Bexar County, Texas. Prewitt and Associates, Austin.

Cox, I.W.

1999 Mission San José Southeast Gate Waterline Installation, Bexar County, Texas. Letter Report No. 126. Center for Archaeological Research, The University of Texas at San Antonio.

Fox, A.A., and I.W. Cox

1991 Testing of the San Jose Mission acequia, San Antonio Missions National Historical Park, Bexar County, Texas. Archaeological Survey Report No. 207. Center for Archaeological Research, The University of Texas at San Antonio.

Fox, D.E.

1970 Archeological Salvage at Mission San José, December 1969 and August 1970. Archeological Report No.3. Texas Historical Commission, Austin.

Hafernik, D.B., and A.A. Fox

1984 Archaeological Testing of Proposed Sewer Line Location at Mission San José. Archaeological Survey Report No. 138. Center for Archaeological Research, The University of Texas at San Antonio.

Hard, R.J., A.A. Fox, I.W. Cox, K.J. Gross, B.A. Meissner, G.I. Méndez, C.L. Tennis, and J.E. Zapata

1995 Excavations at Mission San José y San Miguel de Aguayo, San Antonio, Texas. Archaeological Survey Report No. 218. Center for Archaeological Research, The University of Texas at San Antonio.

Henderson, J., and J.W. Clark, Jr.

1984 Test Excavations at the Acequia and Other Features at Mission San José, Bexar County, Texas. Report No. 25. Texas State Department of Highways and Public Transportation, Highway Design Division. Austin.

Mahoney, R.B.

2001 Mission San José Phase I Expansion Monitoring, City of San Antonio, Bexar County, Texas. Letter Report No. 137. Center for Archaeological Research, The University of Texas at San Antonio.

Nickels, D.L., and A.A. Fox

1999 Archaeological Investigations Within the Church Sacristy at Mission San José (41BX3), San Antonio, Bexar County, Texas. Archaeological Survey Report No. 242. Center for Archaeological Research, The University of Texas at San Antonio.

Scease, A.J. and K.J. Gross

1998 Archaeological Investigation of the Gristmill at Mission San José y San Miguel de Aguayo, San Antonio, Texas. Archaeological Survey Report No. 272. Center for Archaeological Research, The University of Texas at San Antonio. 
Schuetz, M.K.

1970 Excavation of a Section of the Acequia Madre in Bexar County, Texas: and Archeological Investigations at Mission San Jose in April 1968. Archeological Report No. 19. Texas Historical Survey Committee, Austin.

Tennis, C.L.

1998 Investigations of the Southeast Gateway at Mission San José, Bexar County, Texas. Archaeological Survey Report No. 252. Center for Archaeological Research, The University of Texas at San Antonio.

2001 San José. In Archaeological Investigations at Four San Antonio Missions: Mission Trails Underground Conversion Project, edited by C.L. Tennis, pp.55-62. Archaeological Survey Report No. 297. Center for Archaeological Research, The University of Texas at San Antonio.

Tomka, S.A., and A.A. Fox

1998 Mission San José Indian Quarters Wall Base Project, Bexar County, Texas: With Appendixes on the Monitoring of the San José Bus Drive and Granary Parking Lot, and on the Monitoring and Shovel Testing of the San José Service Drive. Archaeological Survey Report No. 278. Center for Archaeological Research, The University of Texas at San Antonio.

1999 Archaeological Investigations of Rainwater Catchment Basins along the South Wall of Mission San José, San Antonio, Texas. Archaeological Survey Report No. 287. Center for Archaeological Research, The University of Texas at San Antonio.

Tomka, S.A., A.A. Fox, and B.A. Meissner

1999 Mission San José Repointing and Underpining Project. San Antonio, Texas. Archaeological Survey Report No. 294. Center for Archaeological Research, The University of Texas at San Antonio.

Tomka, S.A.

2002 Monitoring of the Removal of the Old Granary Service Drive at Mission San José, San Antonio, Texas. Letter Report No. 146. Center for Archaeological Research, The University of Texas at San Antonio.

Traylor, D.E., J.T. Escobedo, Jr., and J.E. Bradford.

1982 Archeological Testing at the Grape Arbor, Mission San José, Bexar County, Texas. Texas Antiquities Permit No. 285. San Antonio Missions National Historical Park, San Antonio.

\section{SAN JUAN CAPISTRANO (41BX5)}

Cargill, D.A.

1996 Stable isotope analysis at Mission San Juan de Capistrano, San Antonio, Texas. Unpublished Masters Thesis, The University of Texas at San Antonio.

Cargill, D.A., and R.C. Robinson

2000 Archaeological Testing and Monitoring of a Service Drive at Mission San Juan Capistrano, San Antonio, Texas. Archaeological Survey Report No. 265. Center for Archaeological Research, The University of Texas at San Antonio. 
Cordova, K.J., A.L. Figueroa, K.M. Ulrich, and J.M. Hunziker.

2005 Archaeological Testing Associated with the Stabilization of the Convento at Mission San Juan Capistrano (41BX5), San Antonio, Bexar County, Texas. Archaeological Survey Report No. 358. Center for Archaeological Research, The University of Texas at San Antonio.

Durst, J.J.

2001 San Juan. In Archaeological Investigations at Four San Antonio Missions: Mission Trails Underground Conversion Project, edited by C.L. Tennis, pp. 1-54. Archaeological Survey Report No. 297. Center for Archaeological Research, The University of Texas at San Antonio.

Fox, A.A.

1993 Archaeological Testing and Monitoring in Connection with a Drainage Project at Mission San Juan Capistrano, San Antonio, Bexar County, Texas. Archaeological Survey Report No. 217. Center for Archaeological Research, The University of Texas at San Antonio.

1999 Monitoring of Core Drilling and Testing at Missions San Juan Capistrano and San Francisco de la Espada, San Antonio, Bexar County, Texas. Manuscript on file at the Center for Archaeological Research, The University of Texas at San Antonio.

Fox, A.A. and I.W. Cox

2000 Archaeological Monitoring for Exterior Lighting and Test Excavations at Mission San Juan Capistrano, Bexar County, Texas. Letter Report No. 131. Center for Archaeological Research, The University of Texas at San Antonio.

Francis, J.F.

1999 Temporal trends in mission populations: a comparison of pathological frequencies and long bone length at Mission San Juan de Capistrano, San Antonio, Texas. Unpublished Masters Thesis, The University of Texas at San Antonio.

Gross, K.J., and R.J. Hard

1998 Archaeological Testing and Monitoring for a Proposed Drainage Channel at Mission San Juan Capistrano. Archaeological Survey Report No. 283. Center for Archaeological Research, The University of Texas at San Antonio.

Schuetz, M.K.

1968 The History and Archeology of Mission San Juan Capistrano, San Antonio, Texas. Archeological Program Reports 10. Texas State Building Commission, Austin.

1969 The History and Archeology of Mission San Juan Capistrano, San Antonio, Texas. Archeological Program Reports 11. Texas State Building Commission, Austin.

1974 The Dating of the Chapel at Mission San Juan Capistrano, San Antonio, Texas. Special Report No. 12. Office of the State Archeologist, Texas Historical Commission, Austin.

1980 The History and Archeology of the Mission San Juan Capistrano, San Antonio, Texas: Excavation of the Convento. Unpublished manuscript on file at the Center for Archaeological Research, The University of Texas at San Antonio.

Scurlock, D.

1976 Archaeological and Architectural Tests at Mission San Juan Capistrano Church. Special Report No. 21. Office of the State Archaeologist, Texas Historical Commission, Austin. 
Tennis, C.L. (editor)

2001 Archaeological Investigations at Four San Antonio Missions: Mission Trails Underground Conversion Project. Archaeological Survey Report No. 297. Center for Archaeological Research, The University of Texas at San Antonio.

Thompson, J.L.

2006 Archaeological Testing Associated with the Stabilization of Room 4 at Mission San Juan Capistrano, San Antonio, Bexar County, Texas. Archaeological Survey Report No. 368. Center for Archaeological Research, The University of Texas at San Antonio.

Tomka, S.A., and J.E. Zapata

20011999 Reburial at Mission San Juan Capistrano, San Antonio, Texas. Archaeological Survey Report No. 311. Center for Archaeological Research, The University of Texas at San Antonio.

Turner, D.D.

1988 Excavations at San Juan Capistrano, 41BX5, Bexar County, Texas. Archaeological Survey Report No. 171. Center for Archaeological Research, The University of Texas at San Antonio.

Ulrich, K.M.

2004 Merging cultures: a comparison of native and colonial ceramics from Mission San Juan de Capistrano, San Antonio, Texas. Unpublished Masters Thesis, The University of Texas at San Antonio

\section{SAN FRANCISCO DE LA ESPADA (41BX4)}

Cargill, D.A., B.A. Meissner, A.A. Fox, and I.W. Cox.

2004 San Antonio Mission Trails Statewide Transportation Enhancement Project, Volume I, Construction Package 1: Archaeological Investigations at Mission San Francisco de la Espada (41BX4), City of San Antonio, Bexar County, Texas. Archaeological Survey Report No. 308. Center for Archaeological Research, The University of Texas at San Antonio.

Cox, I.W.

1993 Archaeological Monitoring at Espada Road Acequia Crossing, South San Antonio, Bexar County, Texas. Archaeological Survey Report No.221. Center for Archaeological Research, The University of Texas at San Antonio.

Fox, A.A.

1981 Test Excavations at Mission San Francisco de la Espada. Archaeological Survey Report, No. 108. Center for Archaeological Research, The University of Texas at San Antonio.

1999 Monitoring of core drilling and testing at missions San Juan Capistrano and San Francisco de la Espada, San Antonio, Bexar County, Texas. Manuscript on file at the Center for Archaeological Research, The University of Texas at San Antonio.

Fox, A.A., and T.R. Hester.

1976 Archaeological Test Excavations at Mission San Francisco de la Espada. Archaeological Survey Report No. 22. Center for Archaeological Research, The University of Texas at San Antonio. 
Gross, K.J.

1997 Archaeological Testing of the New Plaza at Mission San Francisco de la Espada (41BX4), San Antonio, Texas. Archaeological Survey Report No. 262. Center for Archaeological Research, The University of Texas at San Antonio.

Meissner, B.A.

1998 Archaeological Monitoring of an Electrical Conduit Trench at Mission San Francisco de la Espada (41BX4), San Antonio, Bexar County, Texas. Archaeological Survey Report No. 288. Center for Archaeological Research, The University of Texas at San Antonio.

Meskill, F.K.

1992 Archaeological Testing Within the Southeast Corner of the Plaza at Mission Espada, San Antonio, Bexar County, Texas. Archaeological Survey Report No. 208. Center for Archaeological Research, The University of Texas at San Antonio.

Tennis, C.L.

2001 Espada. In Archaeological Investigations at Four San Antonio Missions: Mission Trails Underground Conversion Project, edited by C. L. Tennis, pp.111-116. Archaeological Survey Report No. 297. Center for Archaeological Research, The University of Texas at San Antonio.

Zapata, J.E., M.J. Brown, and J.J. Durst.

2000 Archaeological Excavation of the Priest Quarters, Mission San Francisco de la Espada, 41BX4, San Antonio, Texas. Archaeological Survey Report No. 295. Center for Archaeological Research, The University of Texas at San Antonio.

\section{ESPÍRITU SANTO DE ZÚÑIGA (41VT11)}

de France, S.

1999 Zooarcheological Evidence of Colonial Culture Change: A Comparison of Two Locations of Mission Espíritu Santo de Zúñiga and Mission Nuestra Señora del Rosario, Texas. Bulletin of the Texas Archeological Society 70:169-188.

Lakeman, J.B.

2001 An Analysis of the Ceramic Assemblage from Mission Espíritu Santo de Zuniga (41VT11), Victoria County, Texas. Masters Thesis. Department of Anthropology, The University of Texas at Austin.

Walter, T.L.

1997 The dynamics of culture change and its reflection in the archeological record at Espiritu Santo de Zúñiga, Victoria County, Texas (41VT11). Special Publication No. 7. Studies in Archeology No. 23. Southern Texas Archaeological Association and Texas Archeological Research Laboratory, The University of Texas at Austin.

Walter, T.L., V.K. Hindes, and D.K. Boyd

2005 Spanish Mission Architecture: Examples from the Second (41VT10) and Third (41VT11) Locations of Espíritu Santo, Victoria County, Texas. Bulletin of the Texas Archeological Society 76: $1-28$ 


\section{NuESTRA SEÑORA DEL Rosario (41GD2)}

de France, S.

1999 Zooarcheological Evidence of Colonial Culture Change: A Comparison of Two Locations of Mission Espíritu Santo de Zúñiga and Mission Nuestra Señora del Rosario, Texas. Bulletin of the Texas Archeological Society 70:169-188.

Gilmore, K.K.

1974 Mission Rosario, Archeological Investigations 1973. Archeological Report No. 14, Part 1, Historic Sites and Restoration Department. Texas Parks and Wildlife Department, Austin.

1975 Mission Rosario, Archeological Investigations 1973. Archeological Report No. 14, Part 2, Historic Sites and Restoration Department. Texas Parks and Wildlife Department, Austin.

Nickels, D.L.

20001999 Excavations at Mission Rosario. Archaeological Survey Report No. 298. Center for Archaeological Research, The University of Texas San Antonio.

Ricklis, R.A.

1999 The Spanish Colonial Mission of Espíritu Santo (41GD1) and Nuestra Señora de Rosario, Goliad, Texas: Exploring Patterns of Ethnicity, Interaction, and Acculturation. Bulletin of the Texas Archeological Society 70:133-168.

Ricklis, R.A., S.D. deFrance, and B. Albert

2000 Archeological investigations at the Spanish colonial missions of Espiritu Santo (41GD1) and Nuestra Señora del Rosario (41GD2), Goliad County, Texas. Coastal Archaeological Studies, Inc., Corpus Christi.

Ulrich, K.M., A.L. Figueroa, J.L. Thompson, A.A. Fox, J.M. Hunziker, S.A. Tomka, and C.M. Munoz

2005 Archeological Investigations at Mission Espiritu Santo (41GD1), Goliad County, Texas. Archival Series 3. Texas Archeological Research Laboratory, The University of Texas at Austin, and Archaeological Report 356. Center for Archaeological Research, The University of Texas at San Antonio.

\section{NuESTRA SEÑORA DEL REFUGIO (41RF1)}

Gilmore, K.

1974 Mission Rosario, Archaeological Investigations 1974. Archeological Report 14. Texas Parks and Wildlife Department, Parks Division, Austin.

Tennis, C.L.

2002 Archaeological Investigations at the last Spanish Colonial mission established on the Texas Frontier: Nuestra Señora del Refugio, Refugio County, Texas. Two volumes. Archeological Studies Program Report No. 39. Texas Department of Transportation Environmental Affairs Division, Austin and Archaeological Survey Report No. 315. Center for Archaeological Research, The University of Texas at San Antonio. 


\section{ESPÍRITU SANTO DE ZÚÑIGA (41VT10)}

Hindes, V.K., A.A. Fox, and E.H. Schmiedlin

1999 An Overview of Test Excavations and Documentary Research at 41VT10, the Tonkawa Bank Site, Victoria City Park, Victoria, Texas. Bulletin of the Texas Archeological Society 70:79-96.

Walter, T.L., V.K. Hindes, and D.K. Boyd

2005 Spanish Mission Architecture: Examples from the Second (41VT10) and Third (41VT11) Locations of Espíritu Santo, Victoria County, Texas. Bulletin of the Texas Archeological Society 76: $1-28$.

\section{ESPÍRITU SANTO DE ZÚÑIGA (41GD1)}

de France, $S$.

1999 Zooarcheological Evidence of Colonial Culture Change: A Comparison of Two Locations of Mission Espíritu Santo de Zúñiga and Mission Nuestra Señora del Rosario, Texas. Bulletin of the Texas Archeological Society 70:169-188.

Hunziker, J.M., and A.A. Fox.

1998 Archaeological Testing at Goliad State Park, Goliad County, Texas. Archaeological Survey Report No. 260. Center for Archaeological Research, The University of Texas at San Antonio.

Jackson, A.T.

2005 Appendix A: Excavation of Aranama Mound located Immediately West of the Yard of Aranama (Espíritu Santo) Mission, on the East Bank of the San Antonio River, 1 1 12 Miles S. E. of Goliad in what is now Goliad State park, Goliad County, Texas. One-half Mile N. of La Bahía Mission. In Archeological Investigations at Mission Espíritu Santo (41GD1), Goliad County, Texas, by K.M. Ulrich, A.L. Figueroa, J.L. Thompson, A.A. Fox, J.M. Hunziker, S.A. Tomka, and C.M. Munoz, pp. 79-127. Archival Series 3. Texas Archeological Research Laboratory, The University of Texas at Austin, and Archaeological Report 356. Center for Archaeological Research, The University of Texas at San Antonio.

Lakeman, J.B.

1983 An Analysis of the Ceramic Assemblage from Mission Espíritu Santo de Zuñiga (41VT11), Victoria County, Texas. Unpublished Masters Thesis, The University of Texas at Austin.

Ricklis, R.A.

1999 The Spanish Colonial Mission of Espíritu Santo (41GD1) and Nuestra Señora de Rosario, Goliad, Texas: Exploring Patterns of Ethnicity, Interaction, and Acculturation. Bulletin of the Texas Archeological Society 70: 133-168.

2000 Archeological Investigations at the Spanish Colonial Missions of Espiritu Santo (41GD1) and Nuestra Señora del Rosario (41GD2), Goliad County, Texas. Coastal Archaeological Studies, Inc., Corpus Christi. 
Tunnell, C.

1999 Bronze Cannons and Ardent Spirits at La Bahía. Bulletin of the Texas Archeological Society 70:65-77.

Ulrich, K.M., A.L. Figueroa, J.L. Thompson, A.A. Fox, J.M. Hunziker, and C.L. Munoz.

2005 Archeological Investigations at Mission Espíritu Santo (41GD1), Goliad County, Texas. Archaeological Report No. 356. Center for Archaeological Research, The University of Texas at San Antonio.

Walter, T.L.

1999 A Preliminary Report of the 1997 TAS Field School Excavations in Area A at Mission Espíritu Santo de Zuniga (41VT11), Victoria County, Texas. Bulletin of the Texas Archeological Society 70:97-122.

2000 Archaeological Investigations at the Spanish Colonial Mission of Espíritu Santo de Zuñiga (41VT11), Victoria County, Texas. Ph.D. Dissertation, Department of Anthropology, The University of Texas at Austin.

\section{SAN FRANCISCO XAVIER DE HORCASITAS}

Gilmore, K.K.

1969 The San Xavier Missions: A Study in Historical Site Identification. Report 16. Texas State Building Commission, Austin.

\section{SAN ILDEFONSO}

Gilmore, K.K.

1969 The San Xavier Missions: A Study in Historical Site Identification. Report 16. Texas State Building Commission, Austin.

\section{NUESTRA SEÑORA DEL CANDELARIA}

Gilmore, K.K.

1969 The San Xavier Missions: A Study in Historical Site Identification. Report 16. Texas State Building Commission, Austin.

\section{Nuestra SeÑora de LA LuZ DE ORCoQuisaC}

Tunnell, C.D.

1969 A Lipan Apache Mission: San Lorenzo de la Santa Cruz, 1762-1771, The Archeological Investigation. Texas Memorial Museum. Austin. 


\section{NuESTRO PADRE SAN FRANCISCO DE LAS TEJAS}

Habig, M.A.

1990 Spanish Texas Pilgrimage: The Old Franciscan Missions and Other Spanish Settlements of Texas 1632-1821. Franciscan Herald Press, Chicago.

\section{SANTÍSIMO NOMBRE DE MARÍA}

Habig, M.A.

1990 Spanish Texas Pilgrimage: The Old Franciscan Missions and Other Spanish Settlements of Texas 1632-1821. Franciscan Herald Press, Chicago.

\section{SAN Francisco de los TeJas/SAN Francisco dE LOS NeChES}

Habig, M.A.

1990 Spanish Texas Pilgrimage: The Old Franciscan Missions and Other Spanish Settlements of Texas 1632-1821. Franciscan Herald Press, Chicago.

\section{SAN JOSÉ DE LOS NAZONIS}

Blake, R.B.

1938 Location of the Spanish Missions and Presidios in Nacogdoches County. Southwestern Historical Quarterly. Vol. 41:212-224.

\section{Mission Nuestra SEÑORA DE LA PuRÍSIMA CONCEPCiÓN DE LOS AinAis}

Habig, M.A.

1990 Spanish Texas Pilgrimage: The Old Franciscan Missions and Other Spanish Settlements of Texas 1632-1821. Franciscan Herald Press, Chicago.

\section{Nuestra SEÑORA DE LOS DolORES DE LOS AIS (41SA25)}

Benavides, Jr., A.

1998 Archival Investigations for Mission Nuestra Señora De los Dolores De Los Ais, San Augustine County, Texas: A Catalog of Documents and Maps of the Mission Dolores de los Ais Historical 
Materials Collection. Archeological Studies Program Report No. 11. Environmental Affairs Division, Texas Department of Transportation, Austin.

Carlson, S.B.

1996 Archaeological Investigations at Mission Dolores de los Ais (41SA25), 1995-96, San Augustine County, Texas. Historic Sites Research. College Station.

Carlson, S.B. and J.E. Corbin

1999 Mission Dolores Revisited. Bulletin of the Texas Archeological Society 70:49-57.

Carlson, S.B. and K.L. Quinn

1996 Archaeological Investigations at Mission Dolores de los Ais (41SA25), 1995-96, San Augustine County, Texas. Technical Report No. 1. Historic Sites Research, College Station.

Corbin, J.E.

1977 Archeological Research at 41SA25, Mission Delores de Los Ais, 1977. Stephen F. Austin University, Nacogdoches.

1998 Digging for East Texas Roots. Heritage 16(4):10-15.

Corbin, J.E., A. Kalina, and T.C. Alex.

1980 Mission Dolores de los Ais: Archaeological Investigations of an Early Spanish Colonial Mission, San Augustine County, Texas. Papers in Anthropology No. 2. Stephen F. Austin State University, Nacogdoches.

Corbin, J.E., H.A. Brown, M.G. Canavan, and S. Toups

1990 Mission Dolores de los Ais (41SA25): San Augustine County, Texas: Archaeological Investigation, 1984. Papers in Anthropology No. 5. Stephen F. Austin State University, Nacogdoches.

Gilmore, K.K.

1980 Mission Dolores de los Ais: Historical Background and Field Investigations, 1972-73. In Mission Dolores de los Ais: Archaeological Investigations of an Early Spanish Colonial Mission, San Augustine County, Texas, by J.E. Corbin, A. Kalina, and T.C. Alex, pp. 223-276. Papers in Anthropology No. 2. Stephen F. Austin State University, Nacogdoches.

\section{Nuestra Señora de Guadalupe de los NaCOGdoches}

Blake, R.B.

1938 Location of the Spanish Missions and Presidios in Nacogdoches County. Southwestern Historical Quarterly. Vol. 41:212-224. 


\title{
PRESIDIOS
}

\author{
SAN ELIZARIO
}

Calleros, C.

1969 San Elizario Presidio-Mission. Manuscript in the collection of the Catholic Diocese of El Paso Historical Archives and Museum, El Paso.

Decorme, G.S.J.

n.d. Las Misiones Ysleta, Socorro y San Elizario. Unpublished Manuscript in the El Paso Public Library, El Paso.

Gerald, R.E.

1990 Missions, Presidios, Haciendas, and Caminos of the Paso Del Norte Area. The Artifact 28(3):4158.

Peterson, J.A. and D.O. Brown (editors)

1994 El Valle Bajo: The Culture History of the Lower Rio Grande Valley of El Paso. Archaeological Research, Inc., El Paso, and Hicks and Company, Austin.

Peterson, J.A., T.B. Graves, and D.V. Hill.

2000 The 1995 San Elizario Plaza archaeological project. Archeological Research, Inc., El Paso.

Peterson, J.A., R.A. Lopez, D.O. Brown, and K. Weedman (editors)

1994 Cultural Resources Survey in Socorro and San Elizario El Paso County, Texas Phase III Architectural Studies-San Elizario. Hicks and Company, Austin.

Polk, H., A.E. Martinez, and M.E. Brown.

2000 Archaeological Testing and Monitoring for the Phase III D-S Sewer Project, San Elizario Presidio and Plaza Historic District, El Paso County, Texas. SWCA Cultural Resources Report No. 00-63, Albuquerque.

Vierra, B.J., J. Piper, and R.C. Chapman.

1997 A Presidio Community on the Rio Grande :Phase III Testing and Historical Research at San Elizario, Texas. Office of Contract Archeology, University of New Mexico, Albuquerque.

\section{SAN LUIS DE LAS AMARILLAS}

Gilmore, K.K.

1967 A Documentary and Archeological Investigation of Presidio San Luis de las Amarillas and Mission Santa Cruz de San Sabá, Menard County, Texas. Archeological Program Report No. 9. State Building Commission, Austin.

Weddle, R.S.

1964 The San Sabá Mission. The University of Texas Press, Austin. 


\section{SAN ANTONIO DE BÉJAR}

Figueroa, A.L., and R.P. Mauldin

2005 Test Excavations and Monitoring at 41BX1598: A Multicomponent Historic Site in Bexar County, Texas. Archaeological Report No. 360. Center for Archaeological Research, The University of Texas at San Antonio.

McKenzie, C.M.M.

1995 The 1995 Plaza de Armas Archaeological Monitoring Project, San Antonio, Bexar County, Texas. Archaeology Program, St. Mary’s University, San Antonio.

SANTA CRUZ DEL CÍBOLO (41KA26)

Tennis, C.L., I.W. Cox, O.Ford, A.A. Fox, T.K. Perttula, and S.A. Tomka.

2001 Archaeological Investigations at a Spanish Colonial Site (41KA26-B), Karnes County, Texas. Archaeological Survey Report No. 302. Center for Archaeological Research, The University of Texas at San Antonio.

\section{LORETO DE LA BAHÍA (41VT8)}

Calhoun, C.A.

1999 Majolica and Faience from the Presidio Loreto Site (41VT8). Bulletin of the Texas Archeological Society 70:339-354.

Fox, A.A., and S.A. Tomka

2006 Excavations at Presidio Nuestra Señora de Loreto de la Bahía del Espíritu Santo. Bulletin of the Texas Archaeological Society 77:33-160.

\section{LORETO DE LA BAHÍA (41VT4)}

Gilmore, K.

1973 The Keeran Site, The Probable Site of LaSalle's Fort St. Louis in Texas. Report No. 24. Office of the State Archeologist, Texas Historical Commission, Austin.

Tunnell, C.

1999 Bronze Cannons and Ardent Spirits at La Bahía. Bulletin of the Texas Archeological Society 70:65-77. 


\section{SAN FRANCISCO XAVIER DE GIGEDO}

Gilmore, K.K.

1969 The San Xavier Missions: A Study in Historical Site Identification. Report 16. Texas State Building Commission, Austin.

Habig, M.A.

1990 Spanish Texas Pilgrimage: The Old Franciscan Missions and Other Spanish Settlements of Texas 1632-1821. Franciscan Herald Press, Chicago.

Weddle, R.S.

1964 The San Sabá Mission. The University of Texas Press, Austin.

\section{SAN Agustín DE AHUMADA}

Tunnell, C.D., and J.R. Ambler

1967 Archeological excavations at Presidio San Agustín de Ahumada. Archeological Program Report No. 6. Texas State Building Commission, Austin.

\section{Nuestra SeÑora de LAS Dolores DE LAS TEJAS}

Habig, M.A.

1990 Spanish Texas Pilgrimage: The Old Franciscan Missions and Other Spanish Settlements of Texas 1632-1821. Franciscan Herald Press. Chicago, Illinois.

\section{Some SPAnish COLONial SetTlements RANCHO DE LAS CABRAS}

Cargill, D.A., M. Brown, L.C. Nordt, and C.B. Bousman.

1998 Archaeological Survey at Rancho de las Cabras, San Antonio Missions National Historical Park, 41WN30, Wilson County, Texas. Archaeological Survey Report No. 268. Center for Archaeological Research, The University of Texas at San Antonio.

Fox, A.A., B.A. Houk

1998 Archaeological and Historical Investigations at Rancho de las Cabras, 41WN30, Wilson County, Texas: Fourth Season. Archaeological Survey Report No. 143. Center for Archaeological Research, The University of Texas at San Antonio. 
Ivey, J.E.

1983 Archaeological Testing at Rancho de las Cabras, 41WN30, Wilson County, Texas Second Season. Archaeological Survey Report No. 121. Center for Archaeological Research, The University of Texas at San Antonio.

Ivey, J.E., and A.A. Fox

1981 Archaeological Survey and Testing at Rancho de las Cabras, Wilson County, Texas. Archaeological Survey Report No. 104. Center for Archaeological Research, The University of Texas at San Antonio.

Jones, C.J., and A.A. Fox.

1983 Archaeological Testing at Rancho de las Cabras, Wilson County, Third Season. Archaeological Survey Report No. 123. Center for Archaeological Research, The University of Texas at San Antonio.

Taylor, A.J., and A.A. Fox.

1985 Archaeological Survey and Testing at Rancho de las Cabras, 41WN30, Wilson County, Texas, Fifth Season. Archaeological Survey Report No.144. Center for Archaeological Research, The University of Texas at San Antonio.

\section{VILLA SAN FERNANDO DE BÉJAR}

Cox. I.W.

1985 10th Street Substation Excavation of the Acequia Madre (41BX8), San Antonio, Bexar County, Texas. Archaeological Survey Report No. 153. Center for Archaeological Research, The University of Texas at San Antonio.

1986 Excavations of Portions of the San Pedro Acequia (41BX337) and a Search for the Arocha Acequia, San Antonio, Texas. Archaeological Survey Report No. 161. Center for Archaeological Research, The University of Texas at San Antonio.

1990 Archaeological Monitoring of the San José Acequia (41BX267), Wastewater Facilities Improvements Program, San Antonio, Texas. Archaeological Survey Report No. 176. Center for Archaeological Research, The University of Texas at San Antonio.

1995 Documentation of the San Pedro Acequia (41BX337) at Treviño Street, San Antonio, Texas. Archaeological Survey Report No.230. Center for Archaeological Research, The University of Texas at San Antonio.

Cox, I.W., E.D. Johnson, and C.B. Bousman

1999 Excavations for the Upper Labor Dam Site, Breckenridge Park, San Antonio, Bexar County, Texas. Archaeological Survey Report No. 268. Center for Archaeological Research, The University of Texas at San Antonio.

Cox, I.W., and C.L. Tennis

2000 Historical Overview and Archival Archaeological Investigation for the San Antonio River Improvements Project: Houston to Lexington Segment. Archaeological Survey Report No. 299. Center for Archaeological Research, The University of Texas at San Antonio. 
Figueroa, A.L., and R.P. Mauldin

2005 Test Excavations and Monitoring at 41BX1598: A Multicomponent Historic Site in Bexar County, Texas. Archaeological Report No. 360. Center for Archaeological Research, The University of Texas at San Antonio.

Fox, A,A,

1977 The Archaeological and History of the Spanish Governor's Palace Park. Archaeological Survey Report No. 31. Center for Archaeological Research, The University of Texas at San Antonio.

1978 Archaeological Investigations of Portions of the San Pedro and Alazan Acequias in San Antonio, Texas. Archaeological Survey Report No. 49. Center for Archaeological Research, The University of Texas at San Antonio.

1998 Test Excavations at the Spanish Governor's Palace, San Antonio, Texas. Archaeological Survey Report No. 259. Center for Archaeological Research, The University of Texas at San Antonio.

Fox, A.A., and I.W. Cox

1990 Archaeological Excavations at the Alamo Acequia, Southwest HemisFair Plaza, San Antonio, Bexar County, Texas. Archaeological Survey Report No. 192. Center for Archaeological Research, The University of Texas at San Antonio.

Fox, A.A., I.W. Cox, L.Highley, and D. Hafernik

1989 Archaeological and Historical Investigations at the Site of the New Bexar County Justice Center in Downtown San Antonio, Texas. Archaeological Survey Report No. 184. Center for Archaeological Research, The University of Texas at San Antonio.

Fox, A.A., and M. Renner.

1999 Historical and Archaeological Investigations at the Site of Rivercenter Mall (Las Tiendas), San Antonio, Texas. Archaeological Survey Report No. 270. Center for Archaeological Research, The University of Texas at San Antonio.

Fox, D.E., D. Scurlock, and J.W. Clark

1977 Archaeological Excavations at San Fernando Cathedral, San Antonio, Texas: A Preliminary Report. Office of the State Archeologist, Austin.

Frkuska, A.J., Jr.

1981 Archaeological Investigations at the San Pedro Acequia, San Antonio, Texas. Archaeological Survey Report No. 103. Center for Archaeological Research, The University of Texas at San Antonio.

Hafernik, D.B., I.W. Cox, and A.A. Fox.

1989 Archaeological Investigation of the San Juan Dam, 41BX266, Bexar County, Texas. Archaeological Survey Report No. 179. Center for Archaeological Research, The University of Texas at San Antonio.

Houk, B.A.

1998 Archaeological Survey and Testing in San Pedro Park (41BX19), San Antonio, Texas. Archaeological Survey Report No. 289. Center for Archaeological Research, The University of Texas at San Antonio. 
Labadie, J. H.

1986 La Villita Earthworks (41BX677): San Antonio, Texas A Preliminary Report of Investigations of Mexican Siege Works at the Battle of the Alamo. Archaeological Survey Report No. 159. Center for Archaeological Research, The University of Texas at San Antonio.

McKenzie, C.M.M.

1995 The 1995 Plaza de Armas archaeological monitoring project, San Antonio, Bexar County, Texas. Archaeology Program, St. Mary's University, San Antonio.

Meissner, B.A. (editor)

2000 An Archaeological Assessment of San Pedro Park (41BX19), San Antonio, Texas. Archaeological Survey Report No. 269. Center for Archaeological Research, The University of Texas at San Antonio.

Nickels, D.L.

1996 Excavation of the San Pedro Acequia (41BX337) On the Grounds of the San Antonio Housing Authority. Archaeological Survey Report No. 243. Center for Archaeological Research, The University of Texas at San Antonio.

Nickels, D.L. and I.W. Cox

1996 An Archaeological Assessment of the Alazán Acequia (41BX620) in the Five Points Area of San Antonio, Bexar County, Texas. Archaeological Survey Report No. 253. Center for Archaeological Research, The University of Texas at San Antonio.

Schuetz, M.K.

1970 Excavation of a Section of the Acequia Madre in Bexar County, Texas: and Archeological Investigations at Mission San José in April 1968. Archeological Report No. 19. Texas Historical Survey Committee, Austin.

Tennis, C.L.

1994 Evaluation of Archaeological Material from the Little Church of La Villita Property, San Antonio, Texas. Archaeological Survey Report No. 228. Center for Archaeological Research, The University of Texas at San Antonio.

Zapata, J.E. and B.A. Meissner

2003 San Pedro Springs Park Improvements: Archaeological Testing and Monitoring at 41BX19, San Antonio, Bexar County, Texas. Archaeological Survey Report No. 331. Center for Archaeological Research, The University of Texas at San Antonio.

\section{SAN MARCOS DE NEVE}

Horrell, C.E.

1999 Drawing Linkages Between Global and Local Processes: Archaeological Investigations of Villa San Marcos de Neve, a Spanish Colonial Town on the Frontier. Unpublished Masters Thesis, The University of Texas at San Antonio. 


\section{LA VILLA DE LA BAHÍA}

Ricklis, R.A.

2000 Archeological Testing at 41GD112, La Villa de la Bahía: An Early Historic Site in Goliad County, Texas. Studies in Archeology No. 34. Texas Archeological Research Laboratory, The University of Texas at Austin; and Archeological Studies Program Report No. 15. Environmental Affairs Division, Texas Department of Transportation, Austin. 